\title{
A MEZŐGAZDASÁGI KISÜZEMEK JELLEMZŐI ÉS FEJLESZTÉSI LEHETŐSÉGEI
}


Szerkesztette:

Szerzők:

Közremúködött:

Opponensek:

Felelős kiadó:

Szerkesztőbizottság:
Kemény Gábor

Rácz Katalin

Kemény Gábor
Keszthelyi Szilárd
Tóth Orsolya

Kamárásné Hegedűs Nóra

Vajdicsné Bélteki Beáta

Szabó Dorottya

Dr. Czene Zsolt

Dr. Koós Bálint

Juhász Anikó

Biró Szabolcs

Dublecz Károly

Felföldi János

Fertő Imre

Herdon Miklós

Illés B. Csaba

Kapronczai István

Káposzta József

Kemény Gábor

Kertész Róbert

Keszthelyi Szilárd

\author{
Hamza Eszter \\ Rácz Katalin \\ Varga Éva
}

Szabóné Haszonits Ágnes

Porkoláb Eszter

Pap Gergely

\author{
Lámfalusi Ibolya \\ Pető Károly \\ Potori Norbert \\ Rieger László \\ Stummer Ildikó \\ Szakály Zoltán \\ Szücs István \\ Takács István \\ Tóth József \\ Tóth Tamás \\ Vágó Szabolcs
}

Kiadó:

Agrárgazdasági Kutató Intézet

H-1093 Budapest, Zsil utca 3-5.

Postacím: H-1463 Budapest, Pf.: 944

Telefon: (+36 1) 217-1011

Fax: (+36 1) 217-4469

www.aki.gov.hu

aki@aki.gov.hu

DOI: http://dx.doi.org/10.7896/ak1701

ISSN 2061-8204 (Agrárgazdasági Könyvek sorozat)

ISBN 978-963-491-600-0

Nyomda, kötészet: Primerate Kft.

C Agrárgazdasági Kutató Intézet

Minden jog fenntartva. A kiadvány bármely részének sokszorosítása, adatainak bármilyen formában (nyomtatva vagy elektronikusan) történő tárolása vagy továbbítása, továbbá bármilyen elven működő adatbázis kezelő segítségével történő felhasználása csak a kiadó előzetes írásbeli engedélyével történhet. 


\section{Tartalomjegyzék}

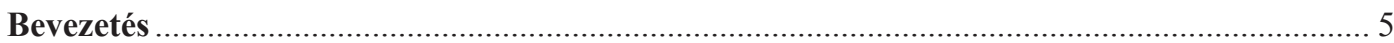

A mezőgazdasági kisüzemekkel foglalkozó kutatások tapasztalatai ..................................... 7

A kisüzemek szerepe, a működésüket befolyásoló főbb tényezők .............................................. 7

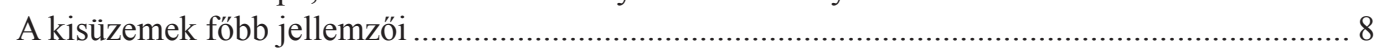

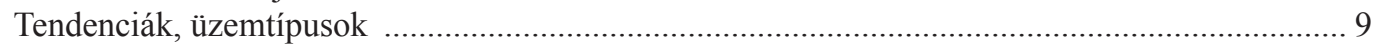

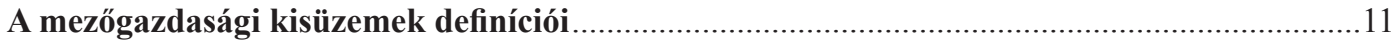

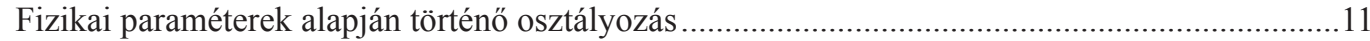

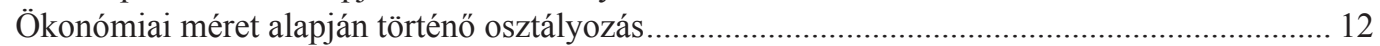

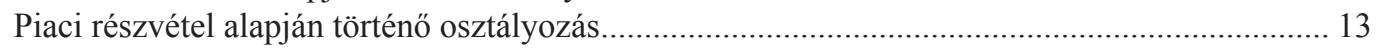

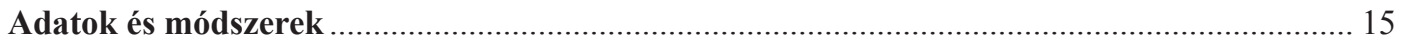

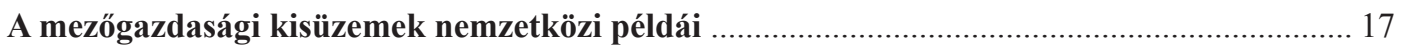

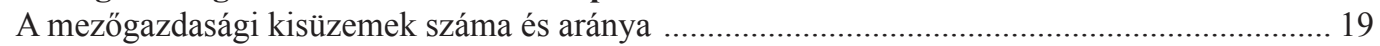

A mezőgazdasági kisüzemek súlya a termelésben és a foglalkoztatásban .................................. 22

A mezőgazdasági kisüzemek foglalkoztatásban betöltött szerepe ............................................ 24

A mezőgazdasági kisüzemek tevékenysége ........................................................................ 26

A mezőgazdasági kisüzemek által előállított STÉ és a létminimum viszonya.............................. 28

A kisüzemek szerepe a hazai mezőgazdasági termelésben ..................................................... 31

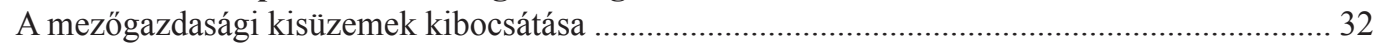

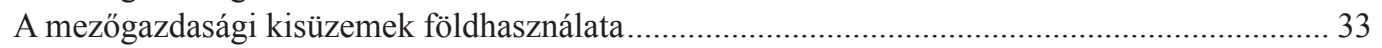

A mezőgazdasági kisüzemek állatállománya ......................................................................... 35

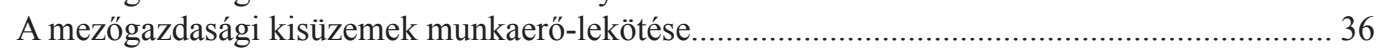

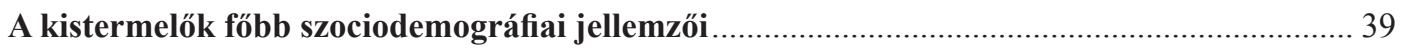

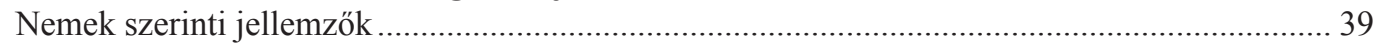

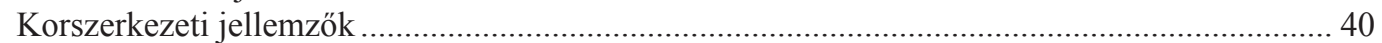

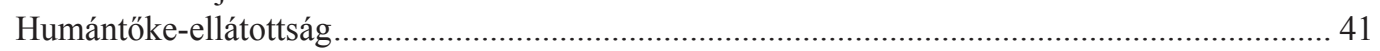

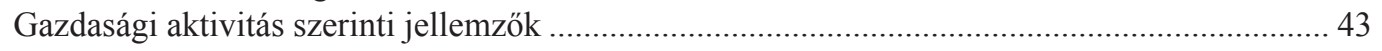

Az egyéb jövedelemszerző tevékenységek szerepe................................................................ 45

A mezőgazdasági kisüzemek gazdálkodásának költség-

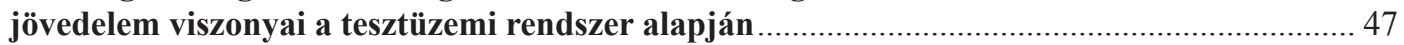

Költség-jövedelem szerkezet méretkategóriák szerinti alakulása ............................................ 47

A mezőgazdasági tevékenység súlya a jövedelemszerkezetben üzemtípusonként ..................... 49

A kisárutermelői kör mezőgazdasági tevékenységének

értékelése az egyéb jövedelemszerző tevékenység alapján..................................................... 51

A kistermelői kör mélyinterjús felmérésének eredményei ...................................................... 61

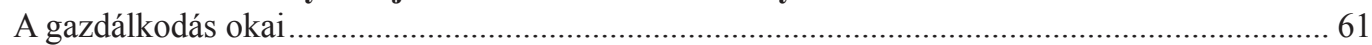

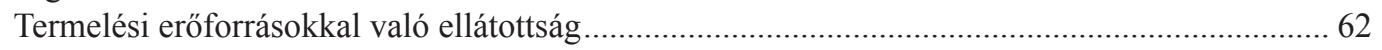

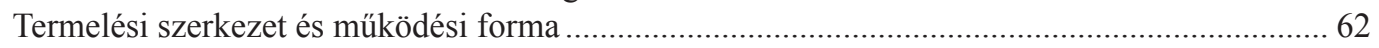

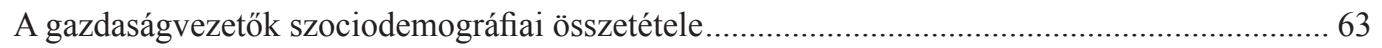

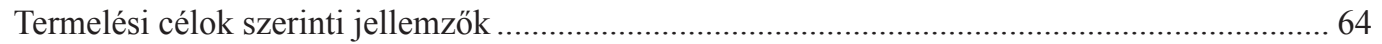

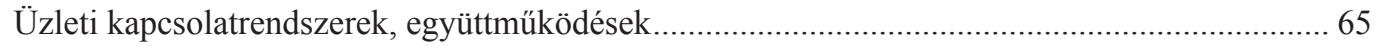

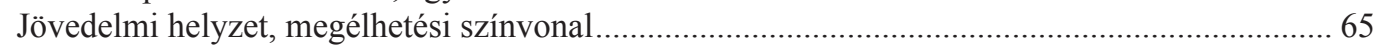

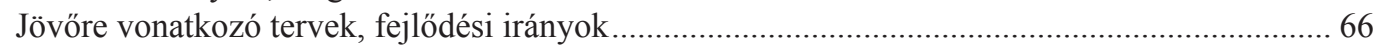

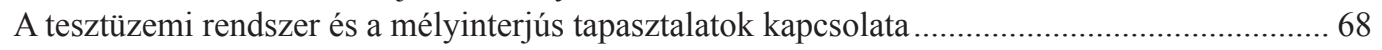


A mezőgazdasági kisüzemek megjelenése a fejlesztéspolitikában ....................................... 71

A mezőgazdasági kisüzemek támogatása a vidékfejlesztési programokban .............................. 71

A mezőgazdasági tartalmú szociálpolitikai és munkaerőpiaci programok tapasztalatai ............... 74

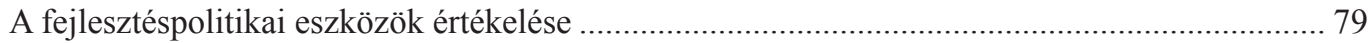

Az árutermelő gazdasággá alakítható kisüzemek számának becslése .................................... 81

A mezőgazdasági üzemek tipizálása a különböző üzemdefiníciók alapján.................................. 81

Kisüzemek típusai klaszterelemzés alapján..................................................................... 82

Az árutermelő gazdasággá alakítható kisüzemi kör becslése a szociológiai háttér alapján .......... 85

Az árutermelő gazdasággá alakítható kisüzemi kör becslése

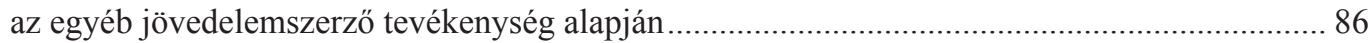

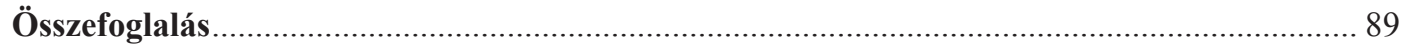

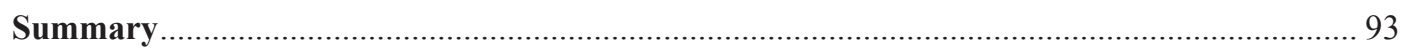

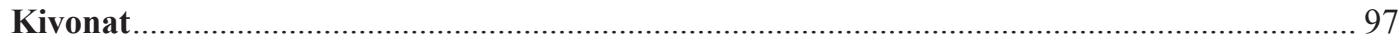

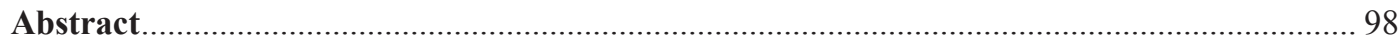

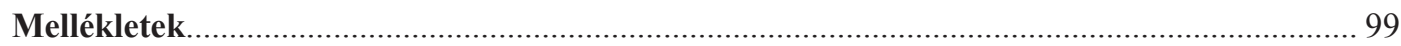

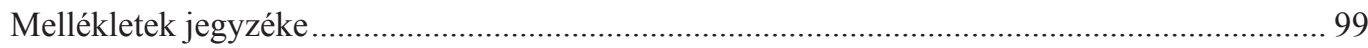

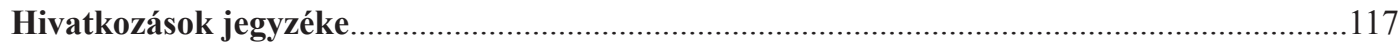




\section{Bevezetés}

A magyar mezőgazdaságot az 1848-as jobbágyfelszabadítás óta jellemezte a duális üzemstruktúra, a nagy- és kisüzemek egymás mellett élése. Ez a rendszer csupán az 1945-ös földosztás nyomán szünt meg, de akkor is csak pár évre vált uralkodóvá a kisüzemi termelési mód, mivel a szocialista kollektivizálás nyomán ismét kialakult a nagyüzemi struktúra, amely az 1960-as évektöl engedélyezett háztáji gazdálkodással karöltve, egymást kiegészítve, a rendszer minden árnyoldalával együtt is jelentős eredményeket ért el a mezőgazdaság és a vidék fejlesztésében.

A rendszerváltás után felbomlott a háztáji gazdálkodás és a nagyüzem összefonódása, a nagyüzemek jelentős része megszűnt, és a megmaradók szinte mindegyike felhagyott a kisüzemek korábbi mértékủ integrálásával. Helyettük a korábbi háztájinál jóval nagyobb méretű egyéni gazdaságok jelentek meg. A mezőgazdasági struktúraváltás során megszüntek a nagyüzemi munkahelyek, amelyeket a kialakuló egyéni gazdaságok források, fejlesztések hiányában és a túlélésükért küzdve értelemszerűen nem tudtak pótolni. Ezáltal akár felértékelődhettek volna a legkisebb üzemek, mezőgazdasági háztartások, ezek azonban a mély gazdasági depresszió nyomán visszaeső kereslet és a korábbi nagyüzemi inputháttér kiesése miatt nem tudtak a korábbi volumenben és formában termelni. Megindult tehát a vidéki mezőgazdasági kisüzemek elsorvadása, ami együtt járt a vidéki állatállomány eltűnésével, a zártkertek, szőlöhegyek, gyümölcsösök tönkremenetelével, elvadulásával, a konyhakertek felszámolásával.

A folyamatot a gazdasági növekedés 1990-es évek második felében bekövetkező beindulása sem fordította meg, mivel a kiskereskedelmi láncokban olcsón megjelenő állati termékek és zöldség-, valamint gyümölcskínálat (ne feledkezzünk meg az agrárolló folyamatos nyílásáról, az agrártermékek relatíve egyre olcsóbbá válásáról ebben az időszakban) azt az érzetet keltette, hogy felesleges és drága dolog bármiféle mezőgazdasági tevékenység végzése. Ennek nyomán a konyhakertek helyét a gazdaságilag fejlettebb vidékeken a díszkertek vették át, és egyre inkább elöregedett az a réteg, amely még ragaszkodott valamilyen szintủ mezőgazdasági tevékenység fenntartásához. Ezzel párhuzamosan tünt el az a korábban apáról fiúra szálló tapasztalat és szakértelem, amely egy vidéki mezőgazdasági háztartás jövedelmező müködtetéséhez elengedhetetlen.

A vidéki mezőgazdasági termelés megítélésében a 2000-es évek második felétől állt be fordulat: egyrészt a világpiaci agrárárrobbanás jelentősen megdrágította az élelmiszereket, másrészt a magyar gazdaság elhúzódó válsága szétfoszlatta azokat a reményeket, hogy a városias területek után a gazdasági fejlödés munkahelyteremtő hatása a vidéki térségek munkaerő-feleslegét is felszívja. Harmadrészt a Magyarország európai uniós csatlakozásával elérhetővé váló agrártámogatások olyan jövedelmeket generáltak és olyan fejlesztési forrásokat nyitottak meg a mezőgazdasági termelők számára, amelyek mellett az egyéb vidéki gazdasági tevékenységek stagnálónak és kevésbé perspektivikusnak tüntek.

A vidéki népesség jövedelmének kiegészítésében máig jelentős szerepet betöltő kisüzemi mezőgazdaság iránti érdeklődés növekedését mutatja a kormányzati támogatással elindított szociális földprogramok népszerüsége, a közfoglalkoztatási programok keretében végzett mezőgazdasági tevékenységek előtérbe kerülése, a települési önkormányzatok által létesített szociális szövetkezetek, valamint egyes alapítványok mezőgazdasági kistermelést támogató programjai.

Tanulmányunk az olyan, jellemzően nem piaci árutermeléssel foglalkozó, nem professzionális, de önállóan tevékenykedő mezőgazdasági kisüzemek helyzetét és jövőbeni kilátásait vizsgálja, amelyeknek nagy hagyományai vannak Magyarországon, azonban súlyuk jelentősen csökkent az elmúlt évtizedekben. Tanulmányunk illeszkedik a témakörben az Agrárgazdasági Kutató Intézetben korábban készült tanulmányok sorába, így különösen Biró és Székely et al. (2012), Székely (2009), Tóth et al., (2009), valamint Tóth (2001, 2002), Tóth és Hamza (2006) munkáihoz. 
Tanulmányunkban arra vállalkozunk, hogy bemutassuk a mezőgazdasági kisüzemek főbb ökonómiai és szociológiai paramétereit, előnyeit és hátrányait a nagyobb méretkategóriát képviselő termelői körhöz képest, illetve lehatároljuk ezen gazdaságok közül az árutermelővé fejleszthető kisüzemek körét.

A témakörben született elemzések, valamint a rendelkezésre álló statisztikai adatok alapján a következő kutatási hipotéziseket fogalmazzuk meg:

1. A hazai környezetben a kisüzemek még mindig meghatározó szerepet töltenek be a mezőgazdasági termelésben és a kiegészítő jövedelemszerzésben.

2. Magyarországon nagyobb a súlya ennek az üzemtípusnak a jövedelmek kiegészítésében, mint az Európai Unió fejlettebb gazdasággal rendelkező tagállamaiban.

3. Ezen gazdaságok túlnyomó része kisegítő gazdaságként müködik, amelynek fő funkciója a más szektorból származó jövedelmek kiegészítése.

4. A mezőgazdasági kisüzemek gazdálkodásának legfontosabb meghatározója a főállású jövedelemszerző tevékenység milyensége.

5. A mezőgazdasági tevékenység kiegészítő jellegéből, valamint a gazdaságvezetőket jellemző szociodemográfiai háttérből (életkor, szakismeret, tőkeellátottság) következően a kisüzemeknek csupán kis hányada fejleszthető tovább főállású árutermelő gazdasággá.

6. Ez a gazdálkodási forma megfelelő eszköz lehet a hátrányos helyzetü háztartások jövedelmi pozíciójának javításához, ez azonban csak jelentős közösségi segítséggel, a gazdálkodáshoz szükséges tudás átadásával, a piacra lépést szaktanáccsal, mentorálással, az együttmüködési formák ösztönzésével, piacszervezéssel elősegítő vidékfejlesztési eszközrendszerrel válhat lehetségessé.

Reményeink szerint tanulmányunk megfelelő segítséget ad a fejlesztéspolitika számára, amely ezáltal célzottabb eszközöket képes kínálni a hátrányos helyzetü vidékeken élő mezőgazdasági háztartásoknak, köztük az árutermelővé válni kívánó mezőgazdasági kisüzemeknek. 


\section{A mezőgazdasági kisüzemekkel foglalkozó kutatások tapasztalatai}

A fejezet a mezőgazdasági kistermelőkre irányuló nemzetközi és hazai kutatások főbb tapasztalatait összegzi, különös tekintettel a kategóriába sorolt üzemek gazdasági, társadalmi funkcióira, ökonómiai, szociológiai jellemzőire, alapvető típusaira, fejlődési kilátásaira.

\section{A kisüzemek szerepe, a müködésüket befolyásoló föbb tényezők}

Egyes megközelítések szerint a mezőgazdasági kisüzemek a többi üzemkategória szerves kiegészítöi, tipikusan olyan tevékenységeket látnak el, amelyeket a nagyobb méretü gazdaságok nem tudnának észszerüen megszervezni (Brüntrup és Heidhues, 2002). Más megfogalmazásban a kisüzemek a többi méretkategóriánál kedvezőtlenebb kibocsátási és hatékonysági mutatóik ellenére is jelentős szerepet töltenek be az agrárgazdaságban, hozzájárulnak a táj és a környezet karbantartásához, a vidék eltartóképességének növeléséhez, munkahelyeket tartanak fenn és hoznak létre (Biró és Székely et al., 2012; Harangi-Rákos et al., 2013; Szumelda, 2013).

Az üzemnagyság és a mérethozadék összefüggéseit vizsgálva Fertő (2002) arra a megállapításra jut, hogy a mérethozadék mellett számos tényező (pl. életkor, iskolai végzettség, mezőgazdaságon kívüli munkahelyek léte, családnagyság, adópolitika) befolyásolja az üzemek méretmegoszlását. Loughrey (2013) a kisüzemek fennmaradásában a mezőgazdaságon kívüli foglalkoztatási, jövedelemszerzési lehetőségeknek tulajdonít kiemelt jelentőséget. Álláspontja szerint a nem mezőgazdasági jövedelemszerzési lehetőségek a gazdaságilag kevésbé versenyképes üzemek fennmaradását és a strukturális változások ütemének csökkenését eredményezik.

Spéder (1994, 1997) kutatásai megerősítik, hogy a kistermelés fennmaradásában több tényező együttes hatása érvényesül. Kiterjedt és intenzív élelmiszer-gazdálkodás jellemzően a falusi háztartásokban zajlik, a városi háztartások más, nem mezőgazdasági tevékenységgel csökkentik fogyasztási kiadásaikat (települési hatás). Kistermeléssel jellemzően nem a leghátrányosabb helyzetủ háztartások foglalkoznak (rétegződéshatás), összefüggésben a tevékenység anyagi erőforrásokat (müvelésbe vonható földterület, az inputanyagok megvásárlásához szükséges forgótőke) és készségeket (termelési ismeretek, munkamorál) igénylő jellegével. A nagyobb háztartásokat intenzívebb termelőtevékenység jellemzi, ennek oka a szükségletek kiterjedtsége, valamint a nagyobb és differenciáltabb munkavagyon rendelkezésre állása (skálahatás).

A kisüzemekkel foglalkozó elemzések markáns irányzatát képezik azok a megközelítések, amelyek szerint a kistermelés nem önkéntes választás, hanem gazdasági szükségszerüség; a vidéki háztartások a magas tranzakciós költségeket eredményező tökéletlen piacok miatt kényszerülnek bevételeik mezőgazdasági jövedelmekkel történő kiegészítésére (Heidhues és Brüntrup, 2003; Davidova et al., 2014). Van der Ploeg (2010) megközelítésében a mezőgazdasági kistermelésből származó tartalékképzés a gazdasági, politikai változásokhoz történő alkalmazkodás egyik formája a vidéki térségekben.

Az Európai Unióban végzett összehasonlító elemzés szerint az unióhoz 2004 után csatlakozott tagállamokban a drasztikus gazdasági reformokhoz és a gazdasági recesszióhoz történő alkalmazkodás során egyfajta túlélési stratégiaként maradtak fenn a kisüzemek és folyamatosan újratermelődnek (Davidova et al., 2009). Ezekben a tagországokban (különösen Bulgáriában és Romániában) a mezőgazdasággal foglalkozó kisüzemek többségének a mezőgazdaság az egyetlen bevételi forrása, szemben a fejlettebb tagországokkal, amelyekben az egyéb tevékenység mellett gazdálkodó, részmunkaidős kisgazdaságok súlya jelentős. 
Számos hazai elemzés megerősíti, hogy a munkahelyek tömeges megszünésével összefüggő megélhetési problémákra adott kényszerü válaszként az agrárdominanciájú, hátrányos helyzetű vidéki térségekben felértékelődött a kistermelés (Kovács et al., 1998; Hamar, 2014; Kovách, 2014). Az ország legszegényebb vidékein, különösen a vállalkozáshiányos, aprófalvas térségekben, a kieső bérjellegü jövedelmek pótlására gyakorta a mezőgazdasági tevékenységgel már felhagyott háztartások is gazdálkodni kezdtek zártkertjeikben, töredékparcelláikon, különösen akkor, ha a környezetükben akadt a termelés koordinálását ellátó integrátor (Kovács és Váradi, 2002; Biró és Székely et al., 2012). Czagány és Fenyővári (2008) elemzése megerősíti, hogy a mezőgazdasági kisüzemek léte nemcsak ágazati, hanem egyszerre társadalompolitikai, szociálpolitikai, adópolitikai kérdés is.

Koós (2014) a Gyöngyösi kistérségben végzett vizsgálat alapján arra a megállapításra jut, hogy a kisgazdaságok fennmaradásának hátterében nem csupán gazdasági, hanem társadalmi aspektusok állnak, például a föld megmüvelésének morális kötelezettsége. Más, a kistermelők nagyszámú jelenlétére magyarázatot kereső elemzések a kistermelés kettős funkciójára, a rászorulók élelmiszerszükségletére, megélhetési tradícióira, valamint a középosztály újabb keletü, természetes élelmiszerek iránti növekvő keresletére hívják fel a figyelmet (Kovách, 2016).

\section{A kisüzemek föbb jellemzői}

A kisgazdaságok megkülönböztető jellemzőjeként az elemzések többsége a családi fogyasztás kielégítésére való törekvést, valamint a profitmaximalizálás mint gazdálkodási cél hátrasorolását emeli ki (Féret, 2013). Más megközelítésben a kisgazdaságok megtermelt jövedelme a háztartás bevételeit egészíti ki, az egyszerü újratermelés költségeinek fedezetét biztosítja (Aragie és McDonald, 2014). A zömmel családi munkaerőre támaszkodó kisgazdaságok további jellemzője a rugalmasság, a gazdaságban dolgozó munkaerő nagyobb érdekeltsége, valamint a termelési kapacitások fölötti kizárólagos rendelkezési jog (Fertő, 2002; Hubbard, 2009). Błażejczyk-Majka et al. (2012) értelmezésében a zömmel családi munkaerőre támaszkodó kisgazdaságokban nagyobb teret kap az ellenőrzés, ami a technológia gazdaságosabb kihasználását eredményezheti.

Az Európai Unió területén müködő gazdaságok jövedelmezőségének és hatékonyságának összehasonlító vizsgálata alapján Kapronczai et al. (2014) kimutatták, hogy bár Magyarország uniós csatlakozása óta a töketermelékenység valamennyi méretkategóriában javult, a kisebb gazdaságok eszközhatékonysága, tőketermelékenysége a technikai felszereltség elmaradottságával összefüggésben alacsonyabb, mint a nagyobb üzemeké. Davidova et al. (2014) elemzése szerint a kis családi gazdaságok fejlődését jelentősen hátráltatja, hogy a beruházásokat lehetővé tevő támogatásokhoz és hitelekhez való hozzáférésük nehézkes, tekintettel arra, hogy nincs fedezetként bevonható földterületük, illetve egyéb ingatlanaik.

Takács és Kovács (2002) a hazai mezőgazdasági kisüzemek kapacitásellátását vizsgálva megállapítják, hogy a kisüzemek többségének nincs megfelelő erő- és munkagépparkja, kapacitásszükségletük kielégítésére pedig nem mindenütt alakult ki megfelelő szervezeti, gazdasági feltételrendszer. A szerzők arra is felhívják a figyelmet, hogy a kisüzemek kisebb hányada kapacitásfelesleggel rendelkezik, ami az eszközállományban lekötött tőke alacsony hatékonyságát eredményezi. A kapacitásfelesleg értékesítése (szolgáltatás formájában) jelentős hatékonyságjavulást eredményezhet. A fölös gépi kapacitások hasznosítását célzó termelői együttmüködések gyakorta az informalitás keretei között maradnak, hatásuk a gazdaságok jövedelmi helyzetére közvetett (Baranyai, 2010; Baranyai et al., 2013).

A kisgazdaságokra irányuló kutatások kiemelt célcsoportját képezik azok a kisüzemek, amelyek árutermelést folytatnak. Davidova et al. (2009) az Európai Unió területén működő gazdaságokat osztályozva megállapítják, hogy elsősorban az intenzív zöldség-, gyümölcs-, dísznövénytermelést folytató, 1-5 hektár közötti kisüzemeket jellemzi árutermelöi tevékenység, amelyek termékfelesle- 
gükkel leggyakrabban a helyi piacokon jelennek meg. A Kelet-Közép-Európában müködő kisüzemek agrárgazdasági teljesítményét európai uniós összevetésben értékelő Forgács (2016) vizsgálati eredményei szerint növekedés és fejlödés elsösorban a specializált kisüzemekben következett be, jelentős országonkénti eltérések mellett.

Juhász et al. (2012) elemzése szerint a kistermelők legfontosabb piacait a közvetlen piaci értékesítés jelenti, amely - noha társadalmi funkciója mérséklődött - folyamatosan tovább élt mint kiskereskedelmi csatorna. További elemzések szerint a kistermelök a kis méretből adódó objektív problémák mellett elsősorban alacsony együttműködési és innovációs készségük miatt szorultak ki a nagy áruházláncokból (Juhász et al., 2008). Seres et al. (2011) vizsgálatai szerint a kisgazdaságok esetében főként a hiányos piaci információk akadályozzák a fogyasztói igények észlelését és a piacra lépési esélyek mérlegelését. Szabó és Juhász (2012) kutatása megerősíti, hogy a közvetlen termékértékesítés lehetőségével élö kistermelőknek a közvetlen kapcsolatok ellenére sincsen reális képe a fogyasztói igényekről, ami a vásárlóerő további apadását eredményezheti.

\section{Tendenciák, üzemtípusok}

Burgerné (2015) a kis családi gazdaságok statisztikai szempontú vizsgálata alapján arra a következtetésre jut, hogy a gazdaságok számának Európa-szerte tapasztalható csökkenése föként a kisgazdaságok megszünésének, nagygazdaságokba olvadásának következménye. Ezt támasztja alá Valkó (2014) elemzése is, amely szerint a hazai üzemstruktúrában a 2000-2013 közötti időszakban megszünt egyéni gazdaságok nagyobb része a kisgazdaságok közül került ki, amelyek területét zömmel a helyi nagygazdaságok vették át.

Hubbard (2009) arra hívja fel a figyelmet, hogy noha az Európai Unió tagországaiban kétségtelenül jelentős mértékü csökkenés következett be a kisgazdaságok számában, az nem volt olyan léptékü, mint amit az ágazatban végbement fejlődési folyamatok alapján valószínüsíteni lehetett. Az Agrárgazdasági Kutató Intézet munkatársai által végzett, az Európai Unióhoz 2004 után csatlakozott tagországokra kiterjedő összehasonlító vizsgálat szerint az EU-10-ek mezőgazdaságában végbement koncentrációs folyamat ellenére a kistermelés még mindig meghatározó szerepet tölt be a mezőgazdaságban, jelentős mértékben hozzájárulva a város-vidék között mutatkozó jövedelemegyenlötlenségek mérséklésében. A kisüzemek fennmaradásához a KAP I. pillérének közvetlen kifizetései is hozzájárultak, lényegében a struktúraváltás ütemét lassítva (Biró et al., 2016).

Számos nemzetközi és hazai elemzés kísérletet tesz a kistermelésben részt vevők osztályozására, rámutatva a kisgazdaságok ökonómiai, szociológiai hátterének összetettségére. A termelötevékenység funkciója alapján a tanulmányok megkülönböztetnek alapvetően önellátásra, időnként eladásra termelö, valamint specializált árutermelő gazdaságokat (Fertő, 1999). A piachoz kapcsolódás módja alapján a lokális piacokra termelő, illetve a kofakereskedelem bázisát adó kisgazdaságok mellett a mezőgazdasági nagyüzemekkel kooperáló, rendszerint egy-egy tevékenységre szakosodó kisüzemek azonosíthatók (Juhász, 1998). Más osztályozás szerint az Európai Unióban müködö kisüzemek szociális, önellátási, illetőleg hobbicélokat szolgáló gazdaságok lehetnek, ökonómiai funkciójuk ugyanakkor a mezőgazdaság jelenlegi fejlettségi, gépesítettségi, technológiai viszonyai között mérséklődik (Burgerné, 2015).

Davidova et al. (2010) az Európai Unió öt tagországának ${ }^{1}$ klaszterelemzésen alapuló vizsgálata alapján a kistermelők hat csoportját azonosítják. Az alacsony jövedelmü részmunkaidős gazdálkodók (low income part-time farmers) nem a profit növelése céljából foglalkoznak mezőgazdasági tevékenységgel, céljuk a háztartás élelmiszer-fogyasztási szükségleteinek kielégítése. E kategóriába sorolhatók a hobbigazdaságok is, amelyekben a termelötevékenység nem kényszer, hanem életmódválasztás következménye. A kistermelők további csoportját képezik az árutermelő orientációjú, piaci

Bulgária, Románia, Magyarország, Lengyelország, Szlovénia. 
korlátokkal rendelkező (commercially oriented market constrained households), valamint az árutermelö orientációjú, piaci korlátok nélküli háztartások (commercially oriented market unconstrained households), amelyek esetében a gazdálkodás technológiai háttere, valamint a termelési szerkezet hasonló, a termékvolumen növelésére irányuló lehetőségek (bevonható földterület, tőke) és preferenciák ugyanakkor eltérőek. További csoportot képeznek a magas jövedelmủ részidős gazdaságok (high-income part-time farmers), valamint az árutermelő orientációjú, külső tényezők által akadályozott háztartások (commercially oriented externally constrained households). A magas jövedelmü részmunkaidős háztartások üzemen kívüli munkahellyel rendelkeznek, amely a gazdaságba beforgatható jövedelmet teremt. Az árutermelői orientációjú, külső tényezők által akadályozott háztartások esetében a legfőbb korlátot a támogatáspolitikai, adóügyi környezet jelenti, ami gyakorta az illegális gazdaság felé tereli a kisüzemek müködtetőit. Végül, de nem utolsósorban Davidova és szerzőtársai elkülönítik a megélhetési orientációjú, alacsony jövedelmű háztartásokat (subsistence oriented low-income households), amelyek túlnyomó része szegénységi küszöb alatti, termelési erőforrásokkal mérsékelten ellátott, növekedésre korlátozottan képes kényszergazdaság.

Az Európai Unió mezőgazdasági kisüzemeinek jövőjét tekintve Thomson és Davidova (2014) három fejlödési utat körvonalaz. A gazdaság felszámolása (Disappearance) föként az idősebb, utóddal nem rendelkező gazdaságvezetők, illetve a fiatal, képzett, mobilabb, kedvező ágazaton kívüli foglalkoztatási kilátásokkal rendelkező üzemvezetők körében várható. A gazdálkodás szinten tartása (Continuation) mellett a gazdálkodók szűkebb csoportjánál bővülés (Expansion) következhet be, amelyet a diverzifikáció, a pluriaktivitás, illetve a fiatalabb generáció belépése kísérhet, jelentős regionális eltérések mellett.

Cooper et al. (2009) a továbbfejlődés lehetőségét a kisüzemek esetében elsősorban az agroturizmusban látják, amihez a kisgazdaságoknál koncentrálódó speciális tudás, a hagyományos termelési, tenyésztési módszerek, az egyedülálló állat- és növényfajok, a magas minőségü ökológiai, hagyományos, magasabb hozzáadott értékü termékek teremtenek alapot. Más álláspont szerint a kistermelőknek csak egy kisebb részhalmaza van abban a helyzetben, hogy kihasználva az új technológiák kínálta lehetőségeket és termelékenységét növelni tudja (Murphy, 2012). Möllers et al. (2009) szerint a kistermelők az önellátási funkció mérséklődése esetén is az agrárstruktúra tartós szereplői maradnak, a globalizációs folyamatok ugyanis felértékelik a hagyományos technológiával elöállított, közvetlenül a termelőtől beszerezhető, ökológiai gazdálkodásból származó termékeket.

A kutatások eredményeit összegezve a legfontosabb tanulság a kisüzemi termelöi kör ökonómiai, társadalmi jellemzőkben megragadható tagoltsága, ami a jövőbeni fejlődési kilátásokat is alapvetően meghatározza. Ezt szem előtt tartva a következő fejezetben ökonómiai, szociológiai szempontok alapján azonosítjuk és részletesen bemutatjuk a mezőgazdasági kisüzemeket, értékeljük agrárgazdasági teljesítményüket, valamint a vidéki gazdaságban betöltött szerepüket. 


\section{A mezőgazdasági kisüzemek definíciói}

A mezőgazdasági üzemek méretük, gazdálkodási céljuk, jövedelemtermelő képességük, megélhetésben betöltött szerepük, munkaerő-felhasználásuk szerint különböző kategóriákba sorolhatók. A statisztikai adatgyüjtések, a szakirodalom és a támogatási jogszabályok is különböző szempontok alapján definiálják az egyes gazdaságcsoportokat. A tanulmány célcsoportját jelentő mezőgazdasági kisüzemek lehatárolásához ezért áttekintjük az említett forrásokban megtalálható kategóriákat és azok definícióit.

A mezőgazdasági kisüzemekkel kapcsolatos nemzetközi szakirodalomban és az uniós támogatáspolitika szóhasználatában elterjedt az „önellátó” (subsistence farm) és a „félig önellátó” (semi subsistence farm) gazdaságok kategóriája. E gazdaságtípusok jellemzőit és gazdálkodási célját megismerve a magyar fordítás nem szerencsés, hiszen nem fejezi ki a gazdálkodás színvonalát, árutermelésben betöltött szerepét. A Központi Statisztikai Hivatal ezt felismerve az általános mezőgazdasági összeírásokban jóval hosszabb, de a lényeget kifejező terminológiát használ e gazdaságcsoportok meghatározására: az „önellátó gazdaság” helyett a „kizárólag saját fogyasztásra termelő gazdaságok”, a „félig önellátó gazdaságok” helyett pedig a „saját fogyasztáson felüli felesleget értékesítő gazdaságok" fogalmát alkalmazza.

Davidova et al. (2009) megjegyzik, hogy az ún. önellátó gazdaságok meghatározására nincsen általánosan elfogadott definíció. A legtöbb meghatározás a háztartások szükségleteinek kielégítését hangsúlyozza. Barnett et al. (1996) az önellátó gazdaságok következő jellemzőit emelik ki:

- a mezőgazdasági tevékenység folytatása a megélhetési stratégia részét képezi;

- a megtermelt termékek közvetlen fogyasztásra kerülnek;

- a termelési folyamatba csak kevés vásárolt nyersanyag kerül;

- az értékesített termékek részaránya alacsony.

Mathijs és Noev (2002) szerint a gazdaságok definiálása a termelés és a fogyasztás szemszögéből egyaránt megtehető. A két végletet a kizárólag saját fogyasztásra termelő és a termékeiket teljes egészében értékesítő gazdaságok jelentik. Széles körben elfogadott, a statisztikai adatgyüjtések (általános mezőgazdasági összeírások, gazdaságszerkezeti összeírások) által is alkalmazott küszöbérték alapján árutermelő gazdaságoknak azok az üzemek tekinthetők, amelyek termékeik több mint 50 százalékát értékesítik, míg a félig önellátó vagy felesleget értékesítő gazdaságok termékeik kevesebb mint 50 százalékával jelennek meg a piacon.

A gazdaságok osztályozása három kritérium: a gazdaság fizikai paraméterei, ökonómiai mérete és a piaci részvétel mértéke alapján lehetséges (Davidova et al., 2010; EU, 2013).

\section{Fizikai paraméterek alapján történő osztályozás}

A gazdaság fizikai paraméterei közül a használt mezőgazdasági terület, az állatállomány nagysága vagy a felhasznált inputok, például a munkaerő alapján lehet az egyes gazdaságtípusok küszöbértékeit meghatározni. Az önellátó vagy félig önellátó gazdaságok definiálására tett kísérletek esetében például a használt földterület vonatkozásában széles körben elfogadott álláspont, hogy ezen gazdaságok használt földterülete 5 hektár vagy az alatti. Ugyanakkor a kevés földterületen jelentős kibocsátással bíró, szakosodott gazdaságok esetében (pl. sertéstartók, ültetvényes gazdaságok, kertészetek) az előállított termékeknek csak elhanyagolható része kerül saját fogyasztásra, így tehát esetükben a gazdaság fizikai mérete nem megfelelő a félig önellátó gazdaságok definiálására (Davidova et al., 2010). Uniószerte a fizikai paraméterek olyan küszöbértékek megállapításánál használatosak, mint például annak eldöntése, hogy mi tekinthető gazdaságnak (gazdaságküszöb) az I. pillér támogatásainak eléréséhez vagy a vidékfejlesztési intézkedések (pl. agrár-környezetgazdálkodási támogatások) jogosultságához. 
A gazdaság földterületének méretén kívül egy további fizikai paraméter lehet a gazdaságok tipizálásánál a munkaerő-ráfordítás alapján történő osztályozás. Ezt a megközelítést alkalmazza az egyesült királyságbeli Környezetvédelmi, Élelmiszer- és Vidékfejlesztési Minisztérium (DEFRA²), amikor az ún. Standard Munkaerő Szükséglet (Standard Labour Requirement, SLR) mutató alapján osztályozza a gazdaságokat, megkülönböztetve a „szabadidős”, a „,részmunkaidős”, valamint a „teljes munkaidős" gazdaságokat. Az Egyesült Királyságban a gazdaságszerkezeti összeírás a gazdaságok méretét az SLR-mutató alapján a következőképpen határozza meg: „Minden olyan gazdaságban végzett mezőgazdasági tevékenység teljes munkaidő-egyenértékes (full-time equivalent, FTE) munkaerőigénye, ami az átlagos méretü és teljesítményü üzemre jellemző körülmények közötti standard együtthatón alapul.” Az öt gazdaságméret-kategória az 1. táblázat szerint alakul.

\section{1. táblázat: A gazdaságok osztályozása teljes munkaidő-egyenérték alapján}

\begin{tabular}{lcc}
\hline \multicolumn{1}{c}{ Gazdaság mérete } & $\begin{array}{c}\text { Teljes munkaidö-egyenérték } \\
\text { (FTE) }\end{array}$ & Gazdaságtípus \\
\hline Nagyon kicsi & 0,5 alatti & szabadidős vagy hobbigazdaság \\
\cline { 2 - 3 } Kis & $0,5-1$ & részmunkaidős gazdaság \\
\hline Közepes & $1-2$ & \\
\cline { 1 - 3 } Nagy & $2-3$ & teljes munkaidős gazdaság \\
\cline { 1 - 3 } Nagyon nagy & $3-5$ & \\
\hline
\end{tabular}

Forrás: UK Farm Classification Document, 2014.

\section{Ökonómiai méret alapján történö osztályozás}

A gazdaságok ökonómiai mérete alapján történő kategorizálás a fizikai paramétereken alapuló méretmeghatározásnál jóval pontosabb és kifejezőbb módszere a gazdaságok tipizálásának. Az ökonómiai méret meghatározására 2010 előtt a standard fedezeti hozzájárulás alapján kifejezett európai méretegységet (EUME) alkalmazták. Kiszámítása úgy történik, hogy az euróban kifejezett standard fedezeti hozzájárulás (SFH) értéket - amely a bevétel és a változó költségek különbözete alapján meghatározott érték - 1200-zal elosztják. Tehát 1 EUME $=1200$ euró SFH-érték. Az Eurostat az 1 EUME alatti gazdaságokat önellátó - azaz kizárólag saját fogyasztásra termelő - gazdaságokként, míg a 8 EUME alattiakat kisgazdaságokként definiálta. Az üzemtipológiához használt SFHegyütthatót a 2010-es adatok feldolgozásától kezdve a standard termelési érték (STÉ, angolul: Standard Output, SO) együttható váltotta fel, ami a mezőgazdasági termelőtevékenységek egységnyi méretére (1 hektár, 1 állat) meghatározott normatív (átlagos időjárási és üzemi feltételekre vonatkoztatott) termelési érték.

Az Eurostat-adatbázisban elérhető osztályozás és az 1242/2008 (EK) rendelet II. mellékletében szereplő ökonómiai méretosztályozás alapján a 4000 euró standard termelési érték (STÉ) alatti gazdaságok tekinthetők úgynevezett félig önellátó gazdaságoknak (EU, 2013). A tesztüzemi rendszer (FADN) módszertana szintén a standard termelési érték alapján kategorizálja a gazdaságokat, három méretkategóriát használva a gazdaság típusától (egyéni vagy társas) függően:

Az egyéni gazdaságok esetében a három ökonómiai méretkategória:

- 25 ezer euró vagy az alatti STÉ-t előállító gazdaságok;

- 25-65 ezer euró közötti STÉ-t előállító gazdaságok;

- 65 ezer euró feletti STÉ-t előállító gazdaságok.

https://statistics.defra.gov.uk/esg/asd/fbs/sub/farm_size.htm. 
A társas gazdaságok esetében a három ökonómiai méretkategória:

- 125 ezer euró vagy az alatti STÉ-t előállító gazdaságok;

- 125-500 ezer euró közötti STÉ-t előállító gazdaságok;

- 500 ezer euró feletti STÉ-t előállító gazdaságok.

\section{Piaci részvétel alapján történő osztályozás}

A gazdaságok a piacon való részvételük alapján is kategorizálhatók. Eszerint azok a gazdaságok tartoznak a „félig önellátó gazdaságok” kategóriájába, amelyekben a megtermelt termékek csak egy része - kevesebb mint fele - kerül piaci értékesítésre (Wharton, 1970). Az általános mezőgazdasági összeírás és a gazdaságszerkezeti összeírások is a gazdaságban elöállított termékek saját fogyasztásra, illetve piaci eladásra kerülö hányada szerint különböztetik meg a gazdaságokat. Ezek alapján a Központi Statisztikai Hivatal (2013) az alábbi gazdaságtípusokat különíti el:

- Kizárólag saját fogyasztásra ${ }^{3}$ termelö gazdaság: a megtermelt termékeket a gazdaság nem értékesíti, csak saját fogyasztás céljából végez mezőgazdasági tevékenységet.

- A termékek több mint felét saját fogyasztásra termelö gazdaság: a megtermelt termékekből a saját fogyasztáson felüli rész értékesítésre kerül. Az értékesítés nem lehet több, mint 50 százalék.

- A termékek több mint felét értékesitésre termelö gazdaság: a megtermelt termékek értékesítése 51 és 100 százalék közötti.

- Kizárólag mezőgazdasági szolgáltatást végző gazdaság: a gazdaság kizárólag mezőgazdasági szolgáltatást végez.

A piaci részvétel alapján történő megközelítést alkalmazták az Európai Mezőgazdasági Vidékfejlesztési Alapból (EMVA) nyújtandó vidékfejlesztési támogatásról szóló 1698/2005. Tanácsi Rendelet 34. cikk (1) bekezdésében is, ahol a félig önellátó gazdaságok fogalma alatt azon mezőgazdasági üzemeket értik, amelyek elsősorban saját fogyasztásra termelnek és a megtermelt termékeik egy részét értékesítik. A jogszabályi meghatározás szándékosan kerülte a fogyasztás és az értékesítés határértékeinek megadását, ezt a tagállamok saját hatáskörben rögzíthették vidékfejlesztési programjaikban a 141-es ,Szerkezetátalakítás alatt álló félig önellátó gazdaságok támogatása” intézkedés alatt. A támogatási feltételek meghatározása során a tagállamok többsége az ökonómiai méret alapján állította fel a félig önellátó gazdaságok küszöbértékeit, amelyek országonként eltérőek voltak. Bulgáriában az 1-4 EUME, Litvániában a 2-4 EUME, Magyarországon a 2-5 EUME, Romániában a 2-8 EUME közötti gazdaságokat tekintették félig önellátó gazdaságnak. Ebből is látható, hogy bár a gazdaságszerkezeti összeírások adatgyüjtéseiben szerepel a gazdaságok piaci részvétel alapján történő megkülönböztetése, mindig felmerül az igény az ökonómiai méret szerinti besorolásra.

Ezt felismerve a 2014-2020-as programozási időszak vidékfejlesztési támogatásai között az említett intézkedés helyébe lépett új intézkedés elnevezésében a „félig önellátó gazdaságok” helyett a „kisüzem”4 terminológia szerepel. Az 1305/2013/EU rendelet értelmében a tagállamok határozzák meg, hogy mely üzemek minősülnek kisüzemnek. A magyar vidékfejlesztési program szerint mezőgazdasági kisüzem az a mikrovállalkozásnak minősülő (jogi vagy természetes személy) mezőgazdasági termelő, akinek mezőgazdasági tevékenységből származó üzemmérete STÉ-módszertan alapján meghaladja az évi 3000 eurót, de nem éri el az évi 6000 eurót (Miniszterelnökség Agrár- és Vidékfejlesztési Programokért Felelős Helyettes Államtitkárság, 2015).

\footnotetext{
Saját fogyasztás: a gazdaságban termelt termékeknek a gazdálkodó és családja által történő fogyasztása. A háziállatok által fogyasztott növényi termékek (takarmányok) nem számíthatók ide, ugyanakkor a családtagoknak és rokonoknak ellenszolgáltatás nélkül átadott/ajándékozott, gazdaságban termelt termékek ide sorolhatók.

${ }_{4}^{4}$ 1305/2013/EU rendelet az Európai Mezőgazdasági Vidékfejlesztési Alapból (EMVA) nyújtandó vidékfejlesztési támogatásról és az 1698/2005/EK tanácsi rendelet hatályon kívül helyezéséröl. 19. cikk 1. a) bekezdés III. pontja.
} 
A gazdaságok osztályozására alkalmazható háromféle kritériumrendszer közül az ökonómiai méret alapján történő lehatárolást tartjuk a legalkalmasabbnak arra, hogy a tanulmányban tárgyalt mezőgazdasági kisüzemeket azonosítsuk. A továbbiakban a 4000 euró standard termelési értéket (STÉ) el nem érő gazdaságok csoportját tekintjük mezőgazdasági kisüzemnek, illetőleg ezen gazdaságok vezetőit kistermelőknek. 


\section{Adatok és módszerek}

Tanulmányunkat alapvetően három információs bázisra építjük. Az egyik a KSH 2010. évi általános mezőgazdasági összeírása, amely részletes szociológiai hátteret ad az összes mezőgazdasági tevékenységet folytató üzemről, beleértve a legkisebb gazdaságokat és a mezőgazdasági háztartásokat, valamint összegyüjti a legfontosabb információkat a gazdaságok méretéről, struktúrájáról, piaci irányultságáról, fogyasztásban betöltött szerepéröl. ${ }^{5}$

A tanulmány másik információs bázisa a tesztüzemi rendszer, amelynek elsődleges feladata, hogy az árutermelő, hivatásszerüen, jövedelemszerzés céljából gazdálkodókról szolgáltasson információkat. Alapesetben ez a rendszer nem tartalmaz információt a nem árutermelö és bizonyos mérethatár alatti kisgazdaságokról, annak ellenére, hogy azok vidékfejlesztési szempontból nagyon fontos szerepet töltenek be. Ennek alapvetően két oka van. Az egyik, hogy a tesztüzemi információs rendszer európai uniós FADN-adatgyüjtési szabályait úgy alakították ki, hogy az csakis azokra az üzemekre koncentráljon, amelyeket a hagyományos agrárpolitikai eszközökkel el lehet érni, hatást lehet rájuk gyakorolni. Ezenfelül a rendszer kialakításánál fontos szempont volt a költségtakarékosság is. Az Európai Unió egyik legköltségesebb éves adatgyüjtésénél jelentős megtakarítás érhető el azzal, hogy csak a legfontosabb mutatók (kibocsátás, jövedelemtermelés, munkaerö-felhasználás) szempontjából meghatározó, nagyobb árutermelö gazdaságokra koncentrál.

Annak érdekében, hogy a fenti érvek ellenére információhoz jussunk a legkisebb gazdaságokról, a 2012-es és a 2013-as évben felmértük a megfigyelési határ alatti, 2000-4000 STÉ üzemméret közötti gazdaságokat is. Ennek során a tesztüzemi rendszer egyszerüsített módszertanát követtük, nem az összes pénzügyi adatot gyüjtöttük be, ugyanakkor a kérdőívünket háztartás-statisztikai elemekkel is kibővítettük. A minta kiválasztása a 2010-es mezőgazdasági összeírás adatai alapján történt. Az alapsokaságból 73203 kisgazdaság (az összes megfigyelési egység 14,9 százaléka) esett a 2000-4000 euró STÉ közötti mérettartományba, az általuk előállított mezőgazdasági kibocsátás viszont mindössze 1,06 százaléka az ágazat teljes kibocsátásának. Ezeket a gazdaságokat egy 300 elemü mintával mértük fel, a tesztüzemi rendszer kiválasztási és súlyozási módszertanát követve.

A tanulmány harmadik információs forrását a strukturált mélyinterjúk jelentették, amelyeket az ország három megyéjében (Somogy, Tolna, Heves) tevékenykedő kistermelők körében készítettünk. ${ }^{6}$ A mintavétel alapját a tesztüzemi rendszerbe 2012-ben és 2013-ban adatot szolgáltató, 2000-4000 euró STÉ méretkategóriába tartozó 300 kisgazdaság képezte. A minta kiválasztására a tesztüzemi adatszolgáltatásban részt vevő könyvelöirodák munkatársainak közremüködésével, az ágazati sajátosságok, valamint a gazdaságvezető aktivitása szerinti jellemzők figyelembevételével került sor. $^{7}$ A mélyinterjúknak keretet adó, közel 30 kérdésből álló adatlap a gazdaság alapvető jellemzői (termelési erőforrásokkal való ellátottság, termékszerkezet) mellett kitért az üzem gazdasági teljesítményére, üzleti kapcsolatrendszerére, a gazdaságvezető, valamint a gazdaságban munkát végzők főbb szociodemográfiai jellemzőire (1. melléklet). A felmérés során összességében 12 interjút készítettünk, amelyek mindegyike értékelhetőnek bizonyult.

Tanulmányunkban leíró módszertant, egyszerü statisztikai elemzéseket, valamint alapvető fajlagos költség-jövedelem mutatókat használtunk fel az egyes gazdaságtípusok jellemzésére. A mezőgazdasági kisüzemek altípusainak azonosítása céljából a 2013. évi tesztüzemi mintán alapuló faktor- és klaszterelemzést is végeztünk. A mezőgazdasági kisüzemek jellemzőinek szemléltetésére

\footnotetext{
Vizsgálatunk során azért támaszkodtunk a 2010. évi általános mezőgazdasági összeírás adataira, mivel a 2013. évi gazdaságszerkezeti összeírás a tanulmány készítésének időszakában még nem került felhasználható formába.

6 Tolna megyében öt, Somogy megyében öt, Heves megyében három kistermelöt kerestünk fel a felmérés során. Egy termelő adatait végül nem vontuk be az elemzésbe, tekintettel arra, hogy üzemmérete a kérdezés időpontjában meghaladta a 4000 euró STÉ méretkategóriát.

A kisgazdaságok beazonosításánál nehézséget jelentett, hogy egy részük a tesztüzemi felmérés óta felszámolta gazdaságát, valamint alacsony árbevétele miatt nem vezet könyvelést, így kapcsolata az adatszolgáltatásban közreműködő könyvelőcégekkel megszakadt. A kistermelök felkutatásáért, a kapcsolatfelvételért, illetve a felmérés technikai lebonyolításában való közreműködésért a könyvelőcégek munkatársait illeti köszönet.
} 
az egyéb üzemekkel történő összehasonlítást választottuk, így az egyéb üzemtípusokat is részletesen elemeztük és bemutattuk.

A gazdaságtípusok elkülönítésénél a statisztikai adatbázisok alapján a gazdaság ökonómiai mérete szerinti megközelítést választottuk oly módon, hogy a tanulmány fókuszterületét a 4000 euró STÉ termelési érték alatti üzemek alkotják. Ezen gazdaságokról a 2010. évi Általános Mezőgazdasági Összeírás adatbázisában részletes termelési és szociológiai adatok állnak rendelkezésre (1. ábra).

\section{1. ábra: A tanulmány információs bázisa és fókuszterülete}

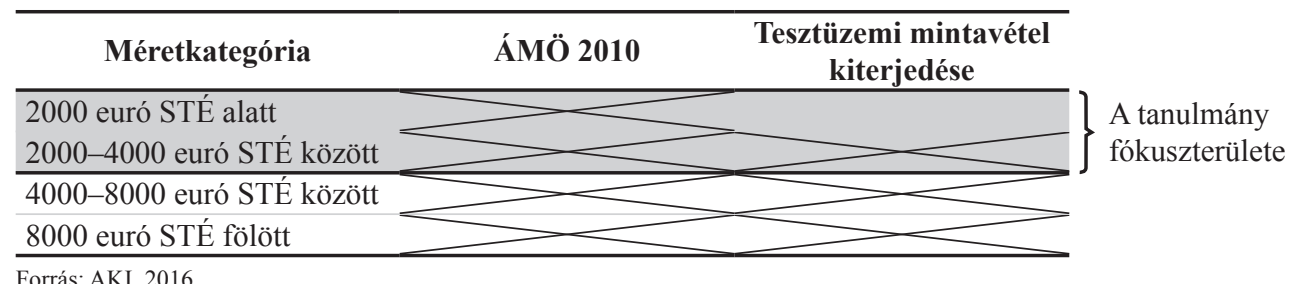

Az 1. ábrán X-szel jelölt téglalapokról, a 2000 euró STÉ fölötti ökonómiai méretủ árutermelő gazdaságokról részletes költség-jövedelem információ áll rendelkezésre a tesztüzemi rendszerben, emellett a 2000-4000 euró STÉ közötti gazdaságokról részletes szociológiai és háztartás-statisztikai adatok is elérhetők, így ebben a körben lehetővé válik az üzemek csoportosítása az egyéb jövedelemszerző tevékenység alapján is. 


\section{A mezőgazdasági kisüzemek nemzetközi példái}

A fejezetben röviden ismertetjük az Európai Unió azon tagállamainak mezőgazdaságát, ahol az alacsony értéket előállító mezőgazdasági üzemek aránya magas. Az EU-tagállamok két csoportja esetében is megfigyelhető a mezőgazdasági kisüzemek jelentős aránya. Az egyik csoportba a mediterrán országok, a másikba a volt szocialista országok tartoznak. A mediterrán országok közül Görögország, Olaszország, Spanyolország, Portugália és Franciaország, a volt szocialista országok közül Bulgária, Csehország, Horvátország, Lengyelország, Magyarország, Románia, Szlovénia és Szlovákia kisüzemeinek fő jellemzőit ismertetjük. Mindkét esetben bemutatunk egy-egy olyan országot, ahol az adott csoporttól eltérő a gazdaságstruktúra. A bemutatott mediterrán országok körében Franciaország, a volt szocialista országok közül Csehország gazdaságszerkezete különbözik erőteljesen a csoportba tartozó többi országétól.

A volt szocialista országok mezőgazdasága különböző úton haladt a rendszerváltás után. Az országok többségében a szocializmus időszakában nagyüzemekben folyt a mezőgazdasági tevékenység, hatalmas területen gazdálkodó állami gazdaságok és termelöszövetkezetek jöttek létre, és mellettük többé-kevésbé jelen voltak a háztáji gazdaságok is. A rendszerváltás után ez a szerkezet szétesett, a termelőszövetkezetek megszüntek és a magángazdaságoké lett a főszerep. Nagyon sokan megfelelő anyagi háttér és szakismeret nélkül kezdtek el gazdálkodni. Például Bulgária nagy múltú mezőgazdasága a rendszerváltozás éveiben szinte a teljes összeomlás szélére jutott, s csak 1997-től kezdődött meg a termelés emelkedése. Másként fejlődött Csehország, ahol nem történtek radikális változások, megmaradt a régi szerkezet, és a jól gépesített nagyüzemek a meghatározók.

A mediterrán országok, a volt szocialista országok, illetve Magyarország kisgazdaságainak jellemzői mellett kitérünk - a nagyon fejlett mezőgazdasággal rendelkező - Franciaország mezőgazdaságának jellemzőire. Franciaország az EU egyik legnagyobb élelmiszer-exportőre, mezőgazdasága az ország eltérő domborzata, éghajlata és talajviszonyai miatt rendkívül változatos. Általában közepes és nagy családi gazdaságok rendezkedtek be árutermelésre, amelyek rendkívül fejlett technológiával, magas színvonalon termelnek. Az EU szabályozásainak és kedvezményeinek köszönhetően számottevő tömegben megmaradtak a kisparaszti birtokok is, főleg az ország déli részén és a hegyvidékeken.

Az elemzés során a 2010. évi teljes körü általános mezőgazdasági összeírás adatait vizsgáltuk. Az egyes országok adatainak összehasonlíthatóságát az Európai Parlament és Tanács 1166/2008. rendelete biztosította, ennek alapján azok a gazdaságok kerültek összeírásra, amelyeknél a mezőgazdasági hasznosítású terület nagysága legalább 1 hektár, illetve ahol a mezőgazdasági hasznosítású terület 1 hektárnál kisebb ugyan, de bizonyos termékhányadot eladásra termeltek, illetve termelési egységük meghaladt egy bizonyos, a rendelet II. mellékletében elöírt fizikai küszöbértéket ${ }^{8}$ (2. táblázat).

A felmérés során az országok többsége az 1166/2008. évi rendeletben meghatározott küszöbértéket alkalmazta (3. táblázat). Görögország, Magyarország, Bulgária és Horvátország alacsonyabb, 0,1-0,5 hektár mezőgazdasági terület használatánál húzta meg a határt, míg Romániában egyáltalán nem volt fizikai korlát, hogy biztosított legyen a mezőgazdasági terület és az állatállomány 98 százalékos lefedettsége. A rendeletben ajánlott küszöbértéknél magasabbat csak Csehország használt a felmérés során, mivel ily módon is elérte a megkövetelt lefedettséget, ezért éppen az általunk vizsgált legkisebb méretủ gazdaságok maradtak ki a megfigyelésből, ezek súlya azonban Csehországban az ország mezőgazdaságának szerkezete miatt csekély volt.

\footnotetext{
8 A tagországok alkalmazhattak ettől eltérő küszöbértéket is, amelyet úgy kellett meghatározniuk, hogy az ország mezőgazdasági területének és az állatállomány állategységekben kifejezett nagyságának legalább 98-98 százaléka megjelenjen az összeírás során. Jellemzően azokat a legkisebb gazdaságokat zárták ki a felmérésböl, amelyek együttesen az adott tagállam közbirtok nélküli teljes használatban lévő mezőgazdasági területének legfeljebb 2 százalékát használták vagy a teljes számosállategység legfeljebb 2 százalékát tartották.
} 
2. táblázat: A gazdaságszerkezeti felmérésekben alkalmazott küszöbértékek ${ }^{\text {a) }}$

\begin{tabular}{lcc}
\hline & Mutató & Küszöbérték \\
\hline Hasznosított mezögazdasági terület & $\begin{array}{c}\text { Szántó, konyhakert, gyep, ültetvények } \\
\text { Szabadföldi ültetvények }\end{array}$ & 5 ha \\
& $\begin{array}{c}\text { Gyümölcsös, bogyós, citrus- } \\
\text { és olívaültetvények, szölök és faiskolák } \\
\text { Friss zöldségfélék, dinnyék } \\
\text { és szamóca - szabadföldi vagy } \\
\text { alacsony védötakarás alatt }\end{array}$ & 1 ha \\
\cline { 2 - 3 } & Dohány & 5 ha \\
\cline { 2 - 3 } $\begin{array}{l}\text { Üvegházban vagy más (járható) } \\
\text { védőtakarás alatt termesztett } \\
\text { növények }\end{array}$ & Komló & 1 ha \\
\hline Szarvasmarhafélék & Gyapot & 5 ha \\
\hline Sertés & Friss zöldségfélék, dinnyék és szamóca & 1 ha \\
\cline { 2 - 3 } & Virágok és dísznövények & 5 ha \\
\hline Juh & Vaiskolákat kivéve) & 1 ha \\
\hline Kecske & Valamennyi & 10 egyed \\
\hline Baromfi & Valamennyi & 50 egyed \\
\hline
\end{tabular}

a) Az Európai Parlament és Tanács 1166/2008. rendeletének II. melléklete.

Forrás: Eurostat, 2010

3. táblázat: A mezőgazdasági területre vonatkozó küszöbértékek a 2010. évi általános mezőgazdasági összeírás során

\begin{tabular}{lc}
\hline \multicolumn{1}{c}{ Ország } & Küszöbérték \\
\hline Románia & nem volt fizikai korlát \\
\hline Görögország & legalább 0,1 hektár mezőgazdasági terület \\
\hline Horvátország & legalább 0,4 hektár mezőgazdasági terület \\
\hline Bulgária & legalább 0,5 hektár mezőgazdasági terület \\
\hline Magyarország & legalább $\mathbf{0 , 1 5}$ ha összes termöterület \\
\hline Franciaország, Lengyelország, Olaszország, & legalább 1 hektár mezőgazdasági terület \\
Portugália, Spanyolország, Szlovénia, Szlovákia & legalább 5 hektár mezögazdasági terület \\
\hline Csehország & \\
\hline
\end{tabular}

Forrás: Eurostat, 2010

Az összeírás adatai megerősítik, hogy az Európai Unió mezőgazdasága egyre inkább a duális szerkezet irányába mozdul el: egyrészről müködnek az árutermelő nagygazdaságok, amelyek a földterület mind nagyobb hányadán az árualap zömét állítják elő; másrészről léteznek a jellemzően gazdasági és/vagy természeti hátránnyal küszködő térségekben tevékenykedő kisgazdaságok, amelyek többnyire a helyi piacokra és/vagy önellátásra termelnek, valamint a földek müvelésben tartásával fontos szerepet töltenek be a vidéki táj arculatának megörzésében (Somai, 2000).

A legutóbbi teljes körü mezőgazdasági összeírás (ÁMÖ) során, 2010-ben az EU 27 tagországában és Horvátországban összesen 12 millió mezőgazdasági egységet regisztráltak, amelyből 7,3 millió gazdaság (60 százalék) standard termelési értéke (STÉ) nem érte el a 4000 eurót. Az STÉ szerinti csoportosításból kiderül, hogy 2010-ben az EU mezőgazdasági egységeinek legerősebb 5 százaléka 
állította elő a bruttó termelési érték 70 százalékát, 20 százaléka a 90 százalékát, 40 százaléka pedig a 97 százalékát. A farmok további 60 százaléka - a 4000 eurónál kevesebb STÉ-t előállítók köre - a 2010. évi bruttó termelési érték alig több mint 3 százalékát termelte meg (2. ábra). Tehát e kisüzemek gazdasági jelentősége ma már marginálisnak mondható, ugyanakkor kiemelkedő szerepet játszanak a természeti táj gondozásában, valamint a vidéki népesség megtartásában, és az utóbbi években a politikai döntéshozók részéröl is egyre nagyobb figyelmet kapnak (EC, 2011).

2. ábra: A standard termelési érték koncentrációja az EU-27 mezőgazdaságában, 2010

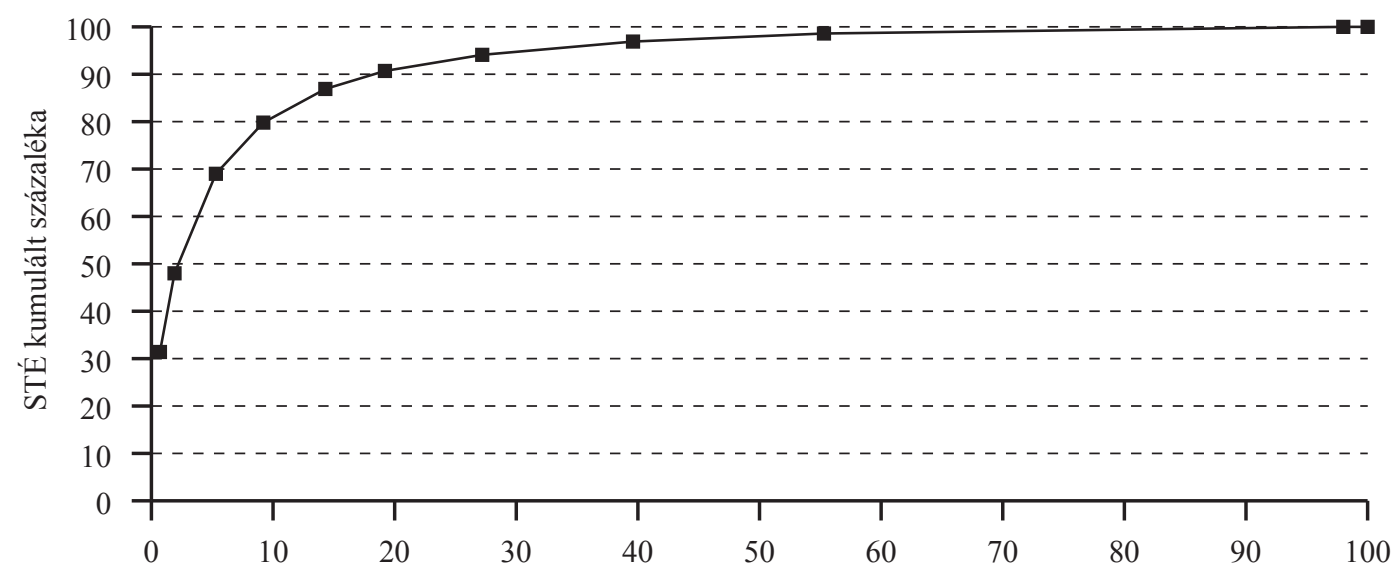

Gazdaságok számának kumulált százaléka

Forrás: Eurostat, 2010

\section{A mezőgazdasági kisüzemek száma és aránya}

Az EU legnagyobb déli tagországaiban és a volt szocialista országokban (Csehország kivételével) a 4000 eurónál kevesebb STÉ-t előállító mezőgazdasági egységek alkotják a gazdaságok legnépesebb csoportját (4. táblázat). Csehországban az összeírás magasabb küszöbértéke eredményezte a legkisebb gazdaságok szokatlanul csekély súlyát. A déli államok esetében az ebbe a kategóriába tartozó gazdaságok száma még a legkevesebb gazdasággal rendelkező Portugáliában is megközelítette a 200 ezret, Olaszországban pedig a 800 ezret 2010-ben. A volt szocialista országok körében Románia rendelkezett a legnagyobb számú, közel három és fél millió kisgazdasággal, de Lengyelországban is több mint háromnegyed millió kisgazdaság müködött. A Magyarországon összeírt 577 ezer mezőgazdasági üzemből 470 ezer tartozott e kategóriába, azaz a mezőgazdasági üzemek mintegy négyötödének standard termelési értéke volt kevesebb, mint 4000 euró, ami a Magyar Nemzeti Bank 2010. évi hivatalos árfolyamán átszámolva 1,1 millió forintnak felelt meg.

A vizsgált országokban átlagosan az összes gazdaság fele, kétharmada tartozott a 4000 euró STÉ alatti kategóriába. Az átlagnál sokkal magasabb, 80 százalékot meghaladó volt a kisgazdaságok aránya Magyarországon, Bulgáriában és különösen Romániában, ahol megközelítette a 90 százalékot. Ugyanakkor az átlagtól lényegesen elmaradt a kisgazdaságok aránya Franciaországban (15 százalék) és Csehországban (17 százalék). Minden országban nagy elemszámú csoportot alkottak a 4-25 ezer euró STÉ-t előállító gazdaságok. A következő méretkategóriákban kevesebb volt a gazdaságok száma, és az 500 ezer eurónál nagyobb STÉ-t elérő gazdaságok aránya az általunk vizsgált 13 ország közül 10 esetében nem érte el az 1 százalékot. Leginkább Csehországban ( 7 százalék), valamint Szlovákiában és Franciaországban jellemzőek a nagy gazdaságok (3. ábra), Csehországban és Franciaországban azonban egészen más a gazdaságstruktúra, egyenletesebb a megoszlás. Cseh- 
országban a gazdaságok 17, Franciaországban 15 százaléka tartozik a 4000 euró STÉ alatti kategóriába. A további kategóriákban inkább emelkedik, mint csökken a számosság. A legtöbb gazdaság Csehországban a 4-25 ezer eurót, Franciaországban a 25-100 ezer, illetve a 100-500 ezer eurót elöállító csoportba tartozott 2010-ben. A vizsgált országok körében Franciaországban és Csehországban nincsen számottevően kevesebb gazdaság a legmagasabb STÉ-kategóriákban, mint a legalacsonyabb kategóriában. Az 500 ezer euró feletti STÉ-t előállítók aránya Franciaországban 2,1, Csehországban 7,3 százalék volt 2010-ben.

4. táblázat: A gazdaságok száma az általuk előállított standard termelési érték nagysága alapján, 2010

\begin{tabular}{|c|c|c|c|c|c|c|}
\hline Ország & $\begin{array}{c}<4 \\
\text { ezer euró }\end{array}$ & $\begin{array}{c}\text { 4-25 } \\
\text { ezer euró }\end{array}$ & $\begin{array}{c}25-100 \\
\text { ezer euró }\end{array}$ & $\begin{array}{c}100-500 \\
\text { ezer euró }\end{array}$ & $\begin{array}{c}>500 \\
\text { ezer euró }\end{array}$ & Összesen \\
\hline Görögország & 381830 & 283900 & 52780 & 4300 & 200 & 723010 \\
\hline Olaszország & 782160 & 532870 & 217250 & 76850 & 11770 & 1620880 \\
\hline Spanyolország & 391840 & 370630 & 161820 & 57010 & 8510 & 989800 \\
\hline Portugália & 191090 & 86280 & 19490 & 7540 & 860 & 305270 \\
\hline Franciaország & 76320 & 122430 & 157000 & 149490 & 10870 & 516100 \\
\hline Magyarország & 469590 & 84810 & 16440 & 4670 & 1330 & 576810 \\
\hline Bulgária & 314590 & 44860 & 7320 & 3000 & 730 & 370490 \\
\hline Csehország & 3940 & 10000 & 4830 & 2430 & 1670 & 22860 \\
\hline Horvátország & 141020 & 77850 & 12660 & 1580 & 160 & 233280 \\
\hline Lengyelország & 775740 & 582150 & 130330 & 16220 & 2180 & 1506620 \\
\hline Románia & 3418930 & 413700 & 19820 & 5570 & 1010 & 3859040 \\
\hline Szlovénia & 33340 & 33770 & 6630 & 860 & 40 & 74650 \\
\hline Szlovákia & 14550 & 6540 & 1530 & 1030 & 810 & 24460 \\
\hline
\end{tabular}

Forrás: Eurostat, 2010

\section{3. ábra: A gazdaságok számának megoszlása az általuk előállított standard} termelési érték nagysága alapján, 2010

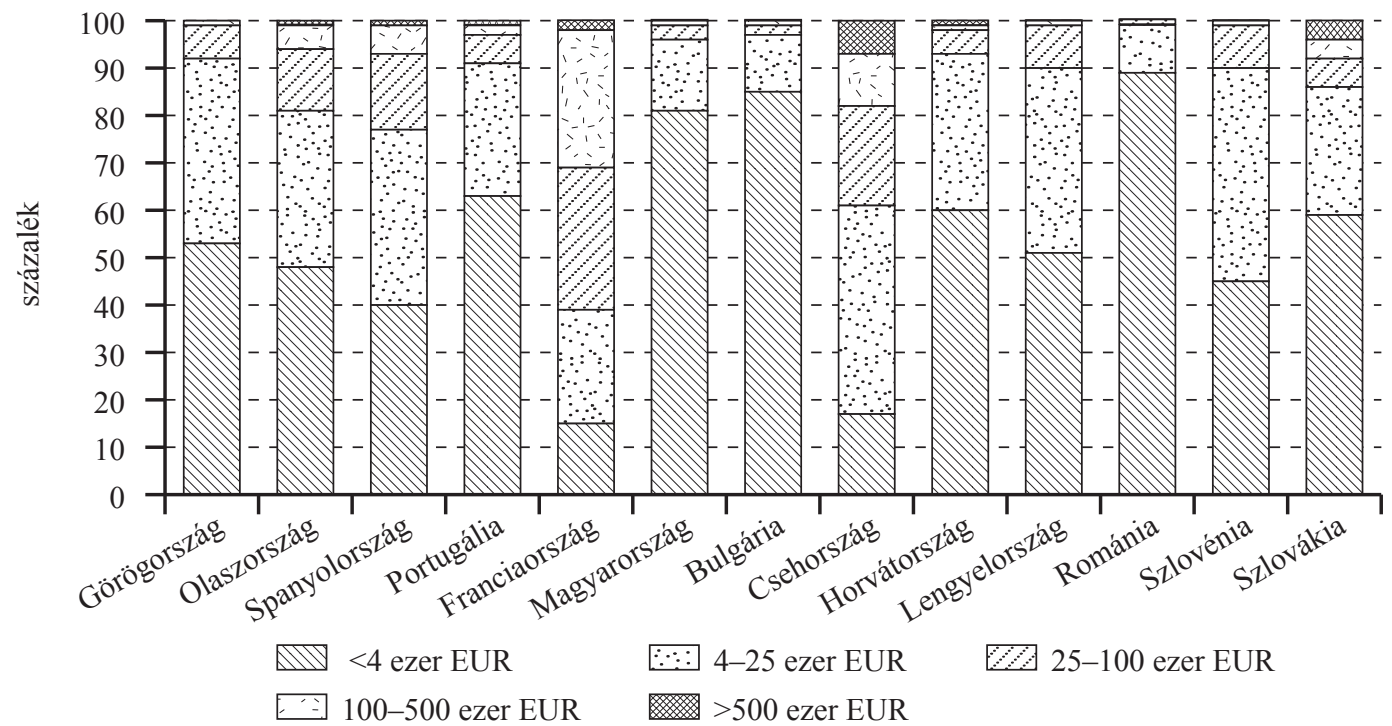

Forrás: Eurostat, 2010 
A vizsgált mediterrán országok gazdaságszerkezete nagyon hasonló volt 2010-ben (3. ábra), ez különösen Görögországra és Olaszországra érvényes. Mindkét országban a gazdaságok harmada esett a legkisebb méretkategóriába, és a további kategóriába sorolható gazdaságok is hasonló arányban voltak jelen. Spanyolországban valamivel kisebb, Portugáliában valamivel nagyobb arányt értek el az 1-es és a 2-es kategóriába tartozó gazdaságok (Spanyolországban 40, Portugáliában 63 százalék volt a kisgazdaságok aránya).

Magyarország 2010. évi gazdaságszerkezete a vizsgált mediterrán országok közül leginkább Portugáliáéhoz, a volt szocialista országok közül pedig Bulgáriáéhoz és Romániáéhoz hasonlít. Portugáliában is igen nagy számban vannak jelen a kisgazdaságok, és hasonló arányban fordulnak elö a nagyobb termelési értéket előállító gazdaságok, de Magyarország esetében ez markánsabban jelenik meg. Bulgária és Románia mezőgazdasága azonos utat járt be és ezen országok gazdaságszerkezete szinte teljesen azonos a magyaréval. A vizsgált évben, 2010-ben elsöprő többségben voltak jelen a kisgazdaságok, és ez az óriási számbeli fölény okozza, hogy a nagyobb termelési értéket előállító gazdaságok láthatatlanná válnak, ha az arányokat vizsgáljuk. Ugyanakkor Romániában is valamivel több mint ezer olyan gazdaság müködött 2010-ben, amely a legmagasabb kategóriába tartozott, azaz a standard termelési értéke meghaladta az 500 ezer eurót.

Bár számuk, részarányuk meglehetősen nagy, a legkisebb jövedelemtermelő képességgel rendelkező gazdaságok minden országban igen kis mértékben járulnak hozzá az adott ország mezőgazdasága által előállított összes termelési értékhez. A kisgazdaságok 2010-ben legkevésbé Csehországban és Franciaországban (0,2, illetve 0,3 százalékkal) vették ki részüket az STÉ előállításából. Ez érthető, hiszen arányuk e két országban a legalacsonyabb. A legnagyobb mértékben Románia kisgazdaságai részesedtek az ország teljes STÉ-jéből. Ez adódik arányukból, ugyanakkor elgondolkodtató, hogy az ország összes mezőgazdasági egységének kilenctizede a teljes STÉ mindössze harmadát állította elö, és az ország mezőgazdasági eredményének közel ötödét az összes romániai gazdaság mindössze 0,03 százalékát kitevő ezer nagygazdaság biztosította.

A legnagyobb, 500 ezer euró STÉ-t meghaladó gazdaságok részesedése az adott ország összes STÉ-jéből minden országban nagyon magas, azaz míg a legerösebb, legnagyobb jövedelemtermelő képességgel rendelkező gazdaságok száma, részaránya csekély, jelentőségük az adott ország mezőgazdasági tevékenységében óriási. Igaz ez Görögország esetében is, ahol 2010-ben a gazdaságok mindössze 0,03 százaléka tartozott a legnagyobb jövedelmet előállítók csoportjába, részarányuk a görög mezőgazdasági üzemek által megtermelt összes STÉ-ből elérte a 6 százalékot (4. ábra). Az STÉ előállításában a legmagasabb arányt Csehországban és Szlovákiában (77-77 százalék) érték el a legnagyobb gazdaságok, ami egyrészt a szerkezetükből adódik, azaz magas az arányuk, másrészt itt megmaradtak a szocializmusban múködő nagygazdaságok. A következő legmagasabb arány (43 százalék) Magyarországon van, ahol a legnagyobb gazdaságok csekély számuk és arányuk (0,2 százalék) ellenére abszolút meghatározó szereplői a mezőgazdaságnak. 
4. ábra: Az egyes STÉ-kategóriákba tartozó gazdaságok részesedése az adott ország teljes STÉ-jéből, 2010

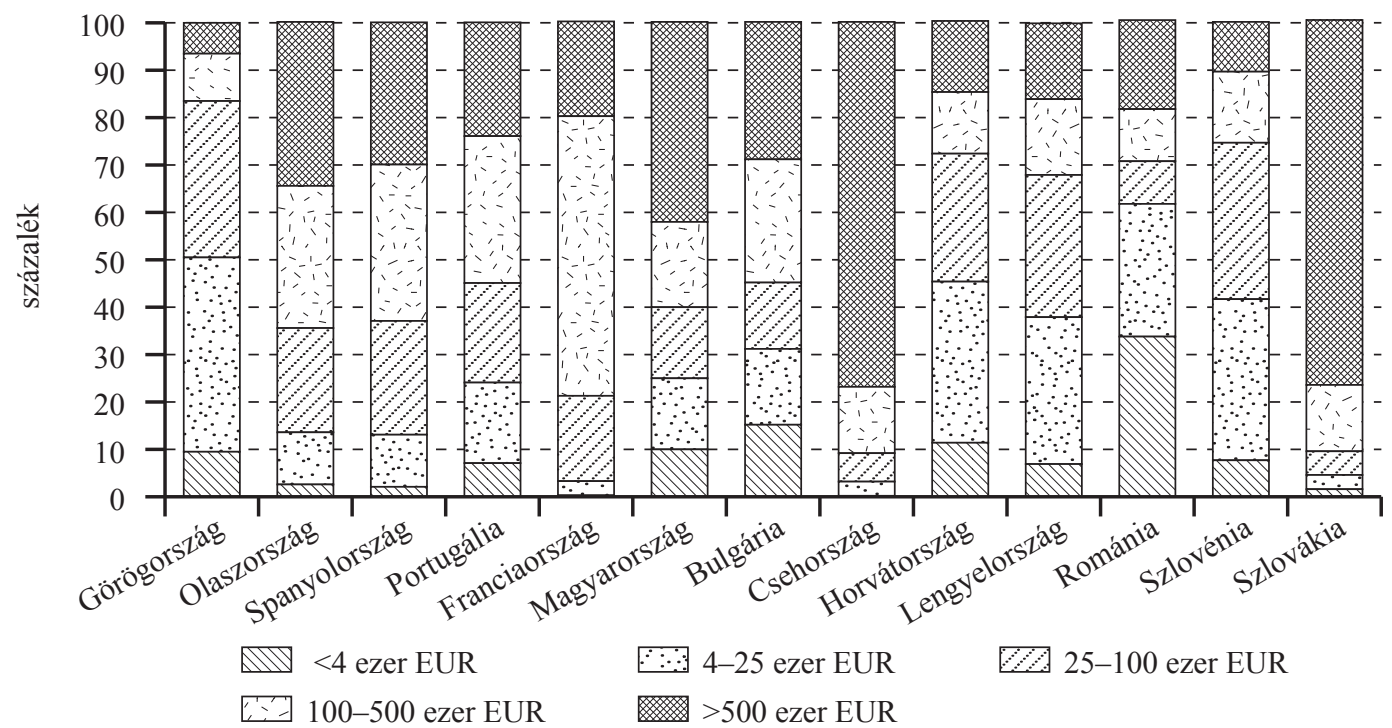

Forrás: Eurostat, 2010

\section{A mezőgazdasági kisüzemek súlya a termelésben és a foglalkoztatásban}

A mezőgazdasági kisüzemek adatait vizsgálva megállapítható, hogy a foglalkoztatásban bírnak a legnagyobb szereppel (5. táblázat). Az összehasonlíthatóság érdekében a mezőgazdasági munka mérésére az éves munkaerőegység (ÉME) használatos, amely egy teljes munkaidős mezőgazdasági munkaerő éves munkavégzése. Az egységnyi munkaerő az EU ajánlása szerint 1800 munkaórának, azaz 225 nyolcórás munkanapnak felel meg.

Az általunk vizsgált országok közül Bulgáriában és Romániában a legmagasabb a kisgazdaságok mezőgazdasági munkaidő-lekötése, az összes mezőgazdasági munka kétharmadát ezekben a gazdaságokban végzik. Magyarországon és Portugáliában is a kisgazdaságok veszik igénybe a legtöbb munkaerőt, hiszen a mezőgazdaságban végzett összes munka mintegy fele a 4000 eurónál kevesebb STÉ-t előállító gazdaságokhoz kötődik. A többi vizsgált országban - Franciaország és Csehország kivételével - a kisgazdaságok részesedése a mezőgazdasági munkából 15-35 százalék között volt.

A kisgazdaságok a mezőgazdasági terület alig 8-15 százalékát müvelték, csak Romániában találunk ennél lényegesen magasabb arányt, ahol a teljes mezőgazdasági terület harmadát birtokolták 2010-ben. A vizsgált 13 ország többségében az állatállomány elhanyagolható részét tartották a kisgazdaságok, részesedésük az adott ország állattenyésztéséből Olaszországban, Spanyolországban és Csehországban mindössze 0,3-0,7 százalék, de Görögországban és Portugáliában is csak 4-5 százalék. Mindössze négy olyan ország van, ahol a kisgazdaságok az állatállomány több mint 10 százalékát tartották 2010-ben; Magyarországon és Horvátországban 13-14 százalékát, Bulgáriában és Romániában 30-36 százalékát. Az elöbbiekböl következik, hogy a volt szocialista országokban - Románia és Bulgária kivételével - ezen üzemek az adott ország mezőgazdasági teljesítményéhez számarányukhoz képest kismértékben járulnak hozzá. Például Spanyolország kisgazdaságai az összes gazdaság közel 40 százalékát adták és az STÉ mindössze 2 százalékát állították elő; szemben Romániával, ahol az összes gazdaság csaknem 90 százaléka az STÉ 34 százalékát termelte meg 2010-ben. 
5. táblázat: A 4000 eurónál kevesebb standard termelési értéket előállító gazdaságok fóbb adatai és arányuk a vizsgált országokban, 2010

\begin{tabular}{|c|c|c|c|c|c|c|c|c|c|c|c|c|}
\hline \multirow[b]{2}{*}{ Ország } & \multicolumn{2}{|c|}{ Üzemszám } & \multicolumn{2}{|c|}{$\begin{array}{l}\text { Mező- } \\
\text { gazdasági } \\
\text { munka }\end{array}$} & \multicolumn{2}{|c|}{$\begin{array}{l}\text { Mező- } \\
\text { gazdasági } \\
\text { terület }\end{array}$} & \multicolumn{2}{|c|}{ Állatlétszám } & \multicolumn{2}{|c|}{$\begin{array}{l}\text { Termelési } \\
\text { érték }\end{array}$} & \multicolumn{2}{|c|}{$\begin{array}{c}\text { Önellátásra } \\
\text { termel }^{\text {a) }}\end{array}$} \\
\hline & 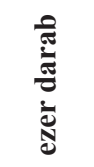 & 苑 & 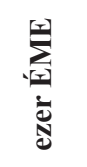 & 范 & 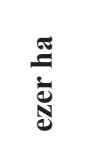 & 范 & 莺 & 范 & 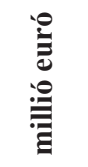 & 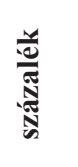 & 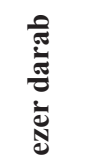 & 范 \\
\hline Görögország & 382 & 52,8 & 91 & 21,2 & 516 & 10,0 & 99 & 4,1 & 651 & 9,5 & 119 & 99,8 \\
\hline Olaszország & 782 & 48,3 & 173 & 18,1 & 1103 & 8,6 & 34 & 0,3 & 1277 & 2,6 & 484 & 75,0 \\
\hline Spanyolország & 392 & 39,6 & 144 & 16,2 & 1961 & 8,3 & 103 & 0,7 & 701 & 2,1 & 2 & 53,1 \\
\hline Portugália & 191 & 62,6 & 171 & 47,2 & 421 & 11,5 & 99 & 4,5 & 328 & 7,1 & 51 & 88,6 \\
\hline Franciaország & 76 & 14,8 & 29 & 3,7 & 559 & 2,0 & 83 & 0,4 & 137 & 0,3 & 12 & 59,3 \\
\hline Magyarország & 470 & 81,4 & 229 & 54,1 & 312 & 6,7 & 328 & 13,2 & 525 & 10,0 & 412 & 90,9 \\
\hline Bulgária & 315 & 84,9 & 270 & 66,3 & 263 & 5,9 & 337 & 29,3 & 386 & 15,2 & 173 & 97,6 \\
\hline Csehország & 4 & 17,2 & 3 & 2,9 & 26 & 0,7 & 7 & 0,4 & 9 & 0,2 & 1 & 47,7 \\
\hline Horvátország & 141 & 60,5 & 64 & 34,5 & 197 & 15,0 & 139 & 13,6 & 240 & 11,4 & 85 & 74,9 \\
\hline Lengyelország & 776 & 51,5 & 614 & 32,4 & 2156 & 14,9 & 321 & 3,1 & 1314 & 6,9 & 342 & 66,9 \\
\hline Románia & 3419 & 88,6 & 1043 & 64,7 & 4272 & 32,1 & 1963 & 36,1 & 3524 & 33,8 & 3243 & 90,3 \\
\hline Szlovénia & 33 & 44,7 & 20 & 26,2 & 73 & 15,0 & 30 & 5,9 & 71 & 7,7 & 30 & 68,0 \\
\hline Szlovákia & 15 & 59,5 & 9 & 15,2 & 41 & 2,2 & 14 & 2,1 & 28 & 1,6 & 11 & 86,8 \\
\hline
\end{tabular}

Franciaország és Csehország esetében a kisgazdaságok alacsony részaránya a többi mutató értékében is jelentkezik. Csekély a súlyuk a foglalkoztatásban, a mezőgazdasági terület müvelésében, az állattartásban, alig járulnak hozzá az ágazat kibocsátásához. Ugyanakkor Franciaországban az önellátásra termelő gazdaságok mintegy 60 százaléka, Csehországban közel fele 4000 eurónál kisebb STÉ-t állít elő.

Magyarországon a kisgazdaságok száma 470 ezer, az összes gazdaság több mint négyötöde volt 2010-ben. A mezőgazdaságban végzett munka 54 százaléka e legkisebb termelési értéket előállító gazdaságokban történt. Az összes mezőgazdasági terület 7 százalékán gazdálkodtak, az állatállomány 13 százalékát tartották, ami lényegesen nagyobb arány, mint a vizsgált mediterrán országokban, és nagyjából belesimul a posztszocialista átlagba. A magyar kisgazdaságok által elöállított termelési érték elérte a mezőgazdaság teljes termelési értékének 10 százalékát, ami ugyancsak több, mint a vizsgált mediterrán országokban, és nagyjából megegyezik a horvát, szlovén, lengyel értékekkel.

Az 5. táblázat utolsó oszlopának adataiból kiderül, hogy a 4000 eurónál kisebb STÉ-t előállító, saját fogyasztásra termelő gazdaságok hány százalékát adják az adott ország összes saját fogyasztásra termelő gazdaságának. Görögországban és Bulgáriában a saját fogyasztásra termelő gazdaságok által elöállított STÉ kevés kivétellel nem érte el a 4000 eurót. Portugáliában és Romániában a saját fogyasztásra termelő gazdaságok mintegy 90 százaléka, Olaszországban és Horvátországban háromnegyede a legkisebbek között volt. A legalacsonyabb arány Spanyolországban és Csehországban látható, ahol a saját fogyasztásra termelő gazdaságoknak körülbelül a fele tartozott ebbe a kategóriába. Spanyolországban a saját fogyasztásra termelő gazdaságok további negyede 4-25 ezer 
euró STÉ-t állított elő, az utolsó negyed ennél is többet, míg Csehországban a saját fogyasztásra termelö gazdaságok másik fele 4-25 ezer euró STÉ-t állított elő. Magyarországon 412 ezer olyan saját fogyasztásra termelő gazdaság volt 2010-ben, amelynek a termelési értéke nem érte el a 4000 eurót. Ezek a gazdaságok a 454 ezer saját fogyasztásra termelö gazdaság több mint 90 százalékát adták.

\section{A mezőgazdasági kisüzemek foglalkoztatásban betöltött szerepe}

Tekintettel arra, hogy a kisgazdaságoknak igen fontos szerepük van a foglalkoztatásban, közelebbröl is érdemes megvizsgálni ezt a területet. A vizsgált körben három olyan ország - Franciaország, Csehország és Szlovákia - található, ahol a teljes lakosság mindössze 1-2 százaléka végez rendszeresen mezőgazdasági munkát, de a többi országban jelentős a mezőgazdaság foglalkoztatásban betöltött szerepe, akár az abszolút számokat, akár az összlakossághoz mért arányt vesszük figyelembe.

A mezőgazdaságnak kiemelkedő szerepe van Romániában, ahol minden harmadik ember rendszeresen tevékenykedik az ágazatban. Csehország és Szlovákia kivételével a többi volt szocialista országban és Görögországban az ország teljes népességéhez viszonyítva a rendszeresen mezőgazdasági munkát végzők aránya meghaladta a 10 százalékot, Spanyolországban, Olaszországban és Portugáliában ennél kisebb, 5-7 százalék közötti volt a részesedésük 2010-ben (6. táblázat).

\section{6. táblázat: A 4000 eurónál kevesebb standard termelési értéket előállító} gazdaságok foglalkoztatásban betöltött szerepe, 2010

\begin{tabular}{|c|c|c|c|c|c|c|c|c|}
\hline \multirow[t]{2}{*}{ Ország } & \multicolumn{2}{|c|}{$\begin{array}{c}\text { Rendszeresen } \\
\text { mezőgazdasági } \\
\text { munkát végzők } k^{\text {a) }}\end{array}$} & \multicolumn{4}{|c|}{$\begin{array}{c}\text { Rendszeresen mezőgazdasági munkát } \\
\text { végzők száma és teljesítménye } \\
\text { a legkisebb gazdaságokban }\end{array}$} & \multirow{2}{*}{$\begin{array}{c}1 \text { gazda- } \\
\text { ságban } \\
\text { ledolgozott }\end{array}$} & \multirow{2}{*}{$\begin{array}{c}1 \text { fó által } \\
\text { teljesí- } \\
\text { tett }\end{array}$} \\
\hline & ezer fö & százalék & ezer fö & százalék & $\begin{array}{c}\text { ezer } \\
\text { ÉME }\end{array}$ & százalék & & \\
\hline Görögország & 1213 & 10,7 & 574 & 47,3 & 91 & 21,2 & 53,7 & 35,7 \\
\hline Olaszország & 3393 & 5,6 & 1505 & 44,4 & 173 & 18,1 & 49,7 & 25,8 \\
\hline Spanyolország & 2227 & 4,8 & 788 & 35,4 & 144 & 16,2 & 82,9 & 41,2 \\
\hline Portugália & 708 & 6,7 & 409 & 57,8 & 171 & 47,2 & 201,9 & 94,2 \\
\hline Franciaország & 1015 & 1,6 & 101 & 10,0 & 29 & 3,7 & 86,1 & 65,0 \\
\hline Magyarország & 1144 & 11,5 & 849 & 74,3 & 229 & 54,1 & 109,8 & 60,7 \\
\hline Bulgária & 739 & 10,0 & 574 & 77,7 & 270 & 66,3 & 193 & 105,7 \\
\hline Csehország & 133 & 1,3 & 8 & 5,9 & 3 & 2,9 & 180 & 91,0 \\
\hline Horvátország & 514 & 11,9 & 271 & 52,7 & 64 & 34,5 & 102 & 53,0 \\
\hline Lengyelország & 3803 & 10,0 & 1710 & 45,0 & 614 & 32,4 & 178 & 80,7 \\
\hline Románia & 7157 & 35,3 & 5938 & 83,0 & 1043 & 64,7 & 69 & 39,5 \\
\hline Szlovénia & 208 & 10,2 & 82 & 39,2 & 20 & 26,2 & 135 & 55,2 \\
\hline Szlovákia & 91 & 1,7 & 30 & 32,9 & 9 & 15,2 & 132 & 64,3 \\
\hline
\end{tabular}

a) Az adott országban rendszeresen mezőgazdasági munkát végzők száma és aránya a teljes népességhez viszonyítva.

Forrás: Eurostat, 2010

A mezőgazdasági munkát végzők igen nagy része a legkisebb gazdaságokhoz kötődik: Romániában és Bulgáriában mintegy négyötödük, Magyarországon is kb. háromnegyedük, a többi vizsgált országban felük-harmaduk. Ahogyan a legkisebb ökonómiai méretkategóriákba tartozó gazdaságok számossága a legnagyobb, úgy ez a gazdaságcsoport ad a legtöbb embernek munkát, ha nem is teljes munkaidőben. Egy gazdaságban jellemzően egy-két fö dolgozik és évente 50-200 nyolcórás mun- 
kanapnak megfelelő időt fordítanak mezőgazdasági munkára; a legkevesebb munkanapot az olasz és a görög (kb. 50 munkanap), a legtöbb munkanapot a bolgár és a portugál kisgazdaságokban (kb. 200 munkanap) dolgozzák le. Franciaországban 1 millióan végeztek rendszeresen mezőgazdasági munkát 2010-ben, körülbelül annyian, mint Görögországban vagy Magyarországon, de a népességhez mért arányuk csak 1,6 százalék. A rendszeresen mezőgazdasági munkát végzők mindöszsze 10 százaléka dolgozott a 4000 eurónál kisebb STÉ-t előállító gazdaságokban. Egy gazdaságban 1 fő átlagosan 65 nyolcórás munkanapnak megfelelő időt tevékenykedett.

Csehországban mindössze 133 ezren végeztek rendszeresen mezőgazdasági munkát 2010-ben, a népességhez mért arányuk csak 1,3 százalék. A rendszeresen mezőgazdasági munkát végzők mindössze 6 százaléka dolgozott a 4000 eurónál kisebb STÉ-t előállító gazdaságokban. Egy gazdaságban 1 fó átlagosan 91 nyolcórás munkanapnak megfelelő időt tevékenykedett, ami magasnak számít, ennél többet csak Portugáliában és Csehországban dolgozott egy-egy fő a legkisebb gazdaságokban. Ha a kisgazdaságokban végzett munkát átszámítjuk teljes munkaidős foglalkoztatottakra, akkor megállapítható, hogy Csehországban mindössze 3 ezer főre lenne szükség a kisgazdaságokban.

7. táblázat: A 4000 eurónál kevesebb standard termelési értéket előállító gazdaságok átlagos üzemmérete, munkaerőigénye, 2010

\begin{tabular}{|c|c|c|c|c|c|c|c|c|}
\hline \multirow[t]{2}{*}{ Ország } & $\begin{array}{c}\text { Gazdaság } \\
\text { STÉ<4000 }\end{array}$ & $\begin{array}{l}\text { Mezőgaz- } \\
\text { dasági } \\
\text { területtel } \\
\text { rendelkező }\end{array}$ & $\begin{array}{l}\text { Üzem- } \\
\text { méret }\end{array}$ & $\begin{array}{c}\text { Állatot } \\
\text { tartó } \\
\text { gazdaság }\end{array}$ & \multirow[t]{2}{*}{$\begin{array}{l}\text { Számos- } \\
\text { állat/ } \\
\text { üzem }\end{array}$} & \multirow{2}{*}{$\begin{array}{c}\text { Éves } \\
\text { munkaerö- } \\
\text { egység/ } \\
\text { üzem }\end{array}$} & \multirow[t]{2}{*}{$\begin{array}{l}\text { STÉ/ } \\
\text { üzem }\end{array}$} & \multirow{2}{*}{$\begin{array}{c}\begin{array}{c}\text { Önel- } \\
\text { látásra } \\
\text { termel }\end{array} \\
\text { százalék }\end{array}$} \\
\hline & ezer darab & ezer darab & $\begin{array}{c}\text { ha/ } \\
\text { üzem }\end{array}$ & $\begin{array}{c}\text { ezer } \\
\text { darab }\end{array}$ & & & & \\
\hline Görögország & 382 & 380 & 1,4 & 98 & 1,0 & 0,2 & 1705 & 31,1 \\
\hline Olaszország & 782 & 780 & 1,4 & 31 & 1,1 & 0,2 & 1633 & 61,8 \\
\hline Spanyolország & 392 & 386 & 5,1 & 60 & 1,7 & 0,4 & 1788 & 0,5 \\
\hline Portugália & 191 & 191 & 2,2 & 119 & 0,8 & 0,9 & 1716 & 26,6 \\
\hline Franciaország & 76 & 74 & 7,6 & 41 & 2,0 & 0,4 & 1790 & 15,7 \\
\hline Magyarország & 470 & 431 & 0,7 & 306 & 1,1 & 0,5 & 1118 & 87,8 \\
\hline Bulgária & 315 & 304 & 0,9 & 241 & 1,4 & 0,9 & 1226 & 55,0 \\
\hline Csehország & 4 & 4 & 6,6 & 3 & 2,6 & 0,8 & 2323 & 26,6 \\
\hline Horvátország & 141 & 141 & 1,4 & 114 & 1,2 & 0,5 & 1704 & 60,6 \\
\hline Lengyelország & 776 & 770 & 2,8 & 332 & 1,0 & 0,8 & 1694 & 44,0 \\
\hline Románia & 3419 & 3287 & 1,3 & 2426 & 0,8 & 0,3 & 1031 & 94,8 \\
\hline Szlovénia & 33 & 33 & 2,2 & 22 & 1,4 & 0,6 & 2121 & 90,6 \\
\hline Szlovákia & 15 & 14 & 2,9 & 11 & 1,3 & 0,6 & 1904 & 77,7 \\
\hline
\end{tabular}

Forrás: Eurostat, 2010

Magyarországon az 1,1 millió rendszeresen mezőgazdasági munkát végző személy közül 850 ezren a kisgazdaságok valamelyikében dolgoztak, egy év alatt személyenként átlagosan 61 munkanapnyi időt fordítva mezőgazdasági munkára. Az EU-szabályok szerinti elméleti munkaerőre (ÉME) átszámítva a kisgazdaságokban mezőgazdasági tevékenységre fordított időt, 229 ezer fö teljes munkaidőben foglalkoztatottat kaptunk. A kisgazdaságok jellemzőiből kiderül, hogy átlagosan 1700 euró STÉ-t állítottak elő és nagy számban saját fogyasztásra termeltek (7. táblázat). Általában kis területen gazdálkodtak, kevés állatot tartottak (pl. egy ló, egy szarvasmarha, néhány sertés, juh vagy pár tucat baromfi). A gazdálkodásra fordított munkaidő egyik országban sem érte el az egy ÉME-t, azaz egyik országban sem volt annyi munkaóra, amennyi egy főállású foglalkoztatott egész éves munkaórája. 


\section{A mezőgazdasági kisüzemek tevékenysége}

A vizsgált országok körében a kisgazdaságok szinte mindegyike rendelkezett mezőgazdasági területtel. A használt földterület meglehetősen kicsi, Görögországban és Olaszországban 1,4 hektár volt 2010-ben, de a legmagasabb átlaggal rendelkező Spanyolországban is alig haladta meg az 5 hektárt gazdaságonként. Franciaországban és Csehországban 97-98 százalék a mezőgazdasági területtel rendelkezők aránya, és a vizsgált körben itt a legmagasabb a gazdaságok átlagos birtokmérete és állatállománya.

Magyarországon a kisgazdaságok 92 százaléka rendelkezett mezőgazdasági területtel. Ez a szám is igen magas, bár alacsonyabb, mint a többi vizsgált mediterrán, illetve volt szocialista országban, és az egy gazdaság által használt terület átlagos nagysága is kisebb, hozzávetölegesen fele a görög-, illetve tizede a franciaországi átlagnak. Ehhez hasonlóan alacsony birtokméret ( 0,9 ha/gazdaság) jellemző még Bulgáriára is.

A vizsgált országok között a földhasználatban jelentős eltérés mutatkozik. Míg a mediterrán országokban a gazdaságok valamivel több mint harmada rendelkezett szántóterülettel, a volt szocialista országokban sokkal több, a gazdaságok legalább kétharmada. A déli tagországokban a kisgazdaságok nagyobb aránya él a föld pihentetésének lehetőségével és a pihentetett terület aránya is magasabb, mint a volt szocialista országokban. A déli államokban átlagosan a kisgazdaságok 14 százaléka a használt területének 14 százalékát pihentette 2010-ben, míg a posztszocialista országok kisgazdaságainak 7 százaléka a használt területének 7 százalékát vette ki a művelés alól ebben az évben. A konyhakert gyakoribb a volt szocialista országokban, mint a mediterrán országokban, de az ültetvény minden országban jellemző.

A vizsgált mediterrán országokban szántót használók körében az átlagterület 2 hektár volt, csak Spanyolországban, Csehországban és Franciaországban volt ennél jóval nagyobb, 5,1-7,6 hektár. Mindegyik országban sokan termesztenek gabonát, ezen belül búzát, árpát, kukoricát. Görögországban és Olaszországban durumbúzát, Portugáliában a legtöbben kukoricát termelnek, és itt gyakoriak a takarmánynövény-, illetve burgonyatermesztők is. Jellemző körükben az ültetvény, ezen belül az olíva, de a szőlő és a gyümölcs is gyakori (8. táblázat).

A volt szocialista országokban a szántót használók körében az átlagterület 2 hektár volt, csak Csehországban közelítette a 7 hektárt. A burgonyatermesztés legalább olyan gyakori, mint a gabona: Szlovéniában a kisgazdaságok fele, Szlovákiában, Lengyelországban harmada, Horvátországban és Bulgáriában negyede termelte, bár meglehetősen kicsi területen. A legnagyobb terület Lengyelországban volt, ahol a kisgazdaságok átlagosan 2300 négyzetméteren termeltek burgonyát, a legkisebb az átlagos terület - 500 négyzetméter - Szlovéniában. A pihentetett terület nagysága 2010-ben csak Magyarország, Lengyelország és Románia esetében haladta meg a szántó 10 százalékát. Ezekben az országokban a kisgazdaságok 7-16 százaléka élt ezzel a lehetőséggel, a többi országban a kisgazdaságok kevesebb mint 5 százaléka pihentetett földet a vizsgált évben. A konyhakert az országok többségében szerves tartozéka a gazdaságnak, átlagosan a kisgazdaságok kétharmada müvelte 2010ben. Kivétel Lengyelország, ahol a kisgazdaságok 20 százaléka rendelkezett konyhakerttel, illetve Csehország, ahol mindössze 3 százalék. A kisgazdaságok jelentős része foglalkozott szőlő-, illetve gyümölcstermesztéssel (8. táblázat). 
8. táblázat: A főbb növényi kultúrák előfordulásának gyakorisága a 4000 eurónál kevesebb standard termelési értéket előállító gazdaságok körében, 2010

százalék

\begin{tabular}{lccccccr}
\hline \multicolumn{1}{c}{ Ország } & Szántó & Gabona & $\begin{array}{c}\text { Konyha- } \\
\text { kert }\end{array}$ & Gyümölcs & Olíva & Szőlö & Erdő \\
\hline Görögország & 34 & 20 & 22 & 6 & 70 & 13 & 1 \\
\hline Olaszország & 40 & 20 & 24 & 9 & 69 & 12 & 16 \\
\hline Portugália & 62 & 35 & 70 & 23 & 49 & 53 & 49 \\
\hline Spanyolország & 37 & 18 & 15 & 20 & 45 & 11 & 16 \\
\hline Franciaország & 39 & 20 & 22 & 3 & 5 & 10 & 25 \\
\hline Magyarország & $\mathbf{5 3}$ & $\mathbf{3 7}$ & $\mathbf{6 8}$ & $\mathbf{1 8}$ & $\mathbf{0}$ & $\mathbf{2 2}$ & $\mathbf{7}$ \\
\hline Bulgária & 68 & 26 & 67 & 12 & 0 & 26 & 2 \\
\hline Csehország & 27 & 16 & 3 & 5 & 0 & 12 & 25 \\
\hline Horvátország & 74 & 58 & 86 & 63 & 12 & 34 & 38 \\
\hline Lengyelország & 85 & 70 & 20 & 13 & 0 & 0 & 45 \\
\hline Románia & 72 & 55 & 66 & 6 & 0 & 24 & 8 \\
\hline Szlovénia & 68 & 36 & 52 & 21 & 2 & 33 & 80 \\
\hline Szlovákia & 75 & 55 & 50 & 2 & 0 & 5 & 2 \\
\hline
\end{tabular}

Megjegyzés: A mezőgazdasági területtel rendelkező gazdaságok részaránya a 4000 eurónál kisebb STÉ-t elóállítók körében.

Forrás: Eurostat, 2010

Franciaország és a mediterrán országok kisgazdaságainak növénytermeléssel kapcsolatos jellemzői nagyon hasonlóak. A francia kisgazdaságok 97 százaléka rendelkezett 2010-ben mezőgazdasági területtel, 37 százalékuk szántóval. Az egyes növényi kultúrával foglalkozók aránya is hasonló volt, de ültetvénnyel, ezen belül gyümölcsössel, olívaültetvénnyel sokkal kevesebben rendelkeztek, mint a mediterrán országokban. Magyarországon a vizsgált kategóriába tartozó gazdaságok közel 62 százaléka müvelt konyhakertet, ültetvénye is harmaduknak volt 2010-ben. A gazdaságok fele használt szántót, amelyen a leggyakrabban gabonát, elsősorban kukoricát termeltek. A gazdaságok 12 százalékánál, azaz minden nyolcadik gazdaságban foglalkoztak burgonyatermeléssel. A pihentetett területek előfordulása a kisgazdaságok körében Magyarországon kevésbé gyakori, 2010-ben csupán 6 százalékuk hagyott földterületet vetetlenül (Valkó, 2011).

Míg növénytermesztéssel szinte mindegyik, haszonállatok tartásával sokkal kevesebb kisgazdaság foglalkozik. Ezekben a gazdaságokban összességében kevés állatot tartanak, de igen széles és színes a paletta. A vizsgált mediterrán országok körében a legkisebb gazdaságok kétharmada tartott állatot Portugáliában, a fele Franciaországban, a negyede Görögországban és mindössze 4 százaléka Olaszországban, vagyis itt a legkevésbé jellemző a kisgazdaságokban a haszonállat jelenléte. Magyarországon nagyságrenddel több, 306 ezer kisgazdaságban, az összes kisméretű gazdaság 65 százalékában volt állat a felmérés évében, 2010-ben. A posztszocialista országok mindegyikében magas az állatot tartó kisgazdaságok aránya. Ezen országok átlagában a legkisebb gazdaságok kétharmada tart állatot. Legalacsonyabb arányt Lengyelországban találunk (43 százalék), legmagasabbat Horvátországban (81 százalék), de Bulgáriában és Szlovákiában is 76, illetve 77 százalék. A magyarázat talán abban rejlik, hogy így képesek leginkább felhasználni a megtermelt növényt, amely jó minőség esetén is valószínüleg kevésbé piacképes kis mennyiségben, illetve a konyhakertben keletkező hulladék és nem értékesíthető gyümölcs állattartás révén hasznosul. 
9. táblázat: Az egyes állatfajok előfordulásának gyakorisága a 4000 eurónál kevesebb standard termelési értéket előállító gazdaságok körében, 2010

százalék

\begin{tabular}{lrrrrrrrr}
\hline \multicolumn{1}{c}{ Ország } & Ló & $\begin{array}{c}\text { Szarvas- } \\
\text { marha }\end{array}$ & Juh & Kecske & Sertés & Baromfi & Nyúl & Méh \\
\hline Görögország & 1 & 0 & 5 & 5 & 1 & 10 & 2 & 0 \\
\hline Olaszország & 1 & 1 & 0 & 0 & 0 & 0 & 0 & 0 \\
\hline Portugália & 7 & 8 & 14 & 9 & 12 & 33 & 17 & 2 \\
\hline Spanyolország & 4 & 4 & 4 & 1 & 4 & 3 & 2 & 0 \\
\hline Franciaország & 8 & 16 & 18 & 2 & 1 & 8 & 7 & 6 \\
\hline Magyarország & $\mathbf{3}$ & $\mathbf{1}$ & $\mathbf{3}$ & $\mathbf{3}$ & $\mathbf{2 9}$ & $\mathbf{3}$ & $\mathbf{4}$ & $\mathbf{1}$ \\
\hline Bulgária & 25 & 23 & 24 & 25 & 22 & 5 & 6 & 6 \\
\hline Csehország & 17 & 17 & 36 & 6 & 4 & 0 & 5 & 3 \\
\hline Horvátország & 1 & 4 & 8 & 5 & 51 & 19 & 5 & 1 \\
\hline Lengyelország & 4 & 11 & 1 & 1 & 8 & 16 & 5 & 1 \\
\hline Románia & 8 & 12 & 4 & 4 & 38 & 38 & 1 & 1 \\
\hline Szlovénia & 5 & 24 & 7 & 5 & 23 & 3 & 8 & 2 \\
\hline Szlovákia & 4 & 33 & 10 & 5 & 46 & 1 & 5 & 2 \\
\hline
\end{tabular}

Megjegyzés: Az állattartó gazdaságok részaránya a 4000 eurónál kisebb STÉ-t elöállítók körében.

Forrás: Eurostat, 2010

A legkisebb gazdaságok körében a legnépszerübb a baromfi, különösen a tojótyúk, amelyet a volt szocialista országokban, valamint Portugáliában és Görögországban átlagosan az állattartó kisgazdaságok felénél, míg a franciaországi kisgazdaságok negyedénél tartottak (9. táblázat). Más állatfajok tartása terén igen nagyok a különbségek. Görögországban leginkább kecskét, juhot és nyulat tartanak, Spanyolországban a ló fordul elő a leggyakrabban, de a juh, a sertés, a szarvasmarha és a nyúl is sok gazdaságban megtalálható. Olaszországban is a ló és a szarvasmarha a legnépszerübb, az állattartó kisgazdaságok harmadában előfordul, és sokan foglalkoznak méhészettel. Portugália állattartása a legszínesebb: itt a baromfi után a nyúl- és a juhtartás a jellemző, de sok gazdaságban van sertés, kecske, ló és szarvasmarha is. Magyarországon a tojótyúk a leggyakoribb a legkisebb gazdaságokban, az állattartó kisgazdaságok kétharmadánál megtalálható volt, a gazdaságok fele tartott sertést 2010-ben; ló, juh, kecske, nyúl vagy egyéb állatfaj jellemzően ezen gazdaságok 5-6 százalékánál fordult elö.

\section{A mezőgazdasági kisüzemek által előállított STÉ és a létminimum viszonya}

Az Eurostat évente közzéteszi a jövedelmi szegénységi küszöbértéket, amely jövedelmi alapú, relatív megközelítés. A mediánjövedelem 60 százalékában határozzák meg a jövedelmi szegénység küszöbértékét. Az általunk vizsgált déli országok körében a szegénységi küszöb átlaga éves szinten 8,5 ezer euró, a volt szocialista országok körében pedig 3,3 ezer euró. Az egy személyre vonatkozó érték Franciaországban volt a legmagasabb, 12 ezer euró, Olaszországban és Spanyolországban 9-10 ezer euró, Görögországban, valamint Szlovéniában 7 ezer euró. A vizsgált déli államok közül Portugáliában a legalacsonyabb a küszöbérték, de így is több mint másfélszerese a posztszocialista országok átlagának. A volt szocialista országok közül Szlovéniában a legmagasabb a szegénységi küszöb értéke, majd Csehország, Szlovákia és Horvátország következik. Az alsó negyed alján Románia található, ahol mindössze 1,2 ezer euró a küszöbérték, azaz tízszeres volt a különbség a legalacsonyabb és a legmagasabb érték között a vizsgált 13 ország körében. A szegénységi küszöb Magyarországon volt a harmadik legalacsonyabb (2,5 ezer euró) Bulgária után, ahol is annak értéke 1,8 ezer euró (10. táblázat). 
Az általunk vizsgált országok kisgazdaságai által elöállított STÉ 2010-ben gazdaságonként 1,7 ezer euró körül volt, Csehországban a legmagasabb (2,3 ezer euró) és Romániában a legalacsonyabb (1,0 ezer euró), kevesebb mint a fele a cseh kisgazdaságok által megtermelt értéknek. Magyarországon volt a második legalacsonyabb, alig több mint 1,1 ezer euró a kisgazdaságok átlagos STÉ-je 2010-ben, Bulgáriában 100 euróval nagyobb értéket, átlagosan 1,2 ezer STÉ-t állítottak elö a legkisebb gazdaságok ebben az évben.

\section{0. táblázat: A szegénységi küszöbérték és a legkisebb gazdaságok standard termelési értékének viszonya az egyes országokban, 2010}

\begin{tabular}{lccc}
\hline \multicolumn{1}{c}{ Ország } & $\begin{array}{c}\text { Jövedelmi szegénység } \\
\text { küszöbértéke, } \\
\text { ezer EUR }\end{array}$ & $\begin{array}{c}\text { 1 gazdaság átlagos STÉ-je, } \\
\text { ezer EUR }\end{array}$ & $\begin{array}{c}\text { Gazdaság kibocsátása a } \\
\text { szegénységi küszöb } \\
\text { százalékában }\end{array}$ \\
\hline Görögország & 7178 & 1705 & 23,8 \\
\hline Olaszország & 9562 & 1633 & 17,1 \\
\hline Spanyolország & 8763 & 1788 & 20,4 \\
\hline Portugália & 5207 & 1716 & 33,0 \\
\hline Franciaország & 11976 & 1790 & 14,9 \\
\hline Magyarország & $\mathbf{2 5 4 4}$ & $\mathbf{1 1 1 8}$ & $\mathbf{4 3 , 9}$ \\
\hline Bulgária & 1810 & 1226 & 67,7 \\
\hline Csehország & 4235 & 2323 & 54,8 \\
\hline Horvátország & 3486 & 1704 & 48,9 \\
\hline Lengyelország & 2643 & 1694 & 64,1 \\
\hline Románia & 1222 & 1031 & 84,4 \\
\hline Szlovénia & 7042 & 2121 & 30,1 \\
\hline Szlovákia & 3670 & 1904 & 51,9 \\
\hline
\end{tabular}

Forrás: Eurostat, 2010

Az Eurostat által publikált jövedelmi szegénységi küszöbértéket összevetve a legkisebb ökonómiai méretkategóriába tartozó gazdaságok STÉ-jével, lényeges különbség mutatkozik a mediterrán országok és a volt szocialista országok között. A mediterrán országokban a legkisebb gazdaságokban előállított érték legfeljebb a harmadát fedezi egy személy legalacsonyabb szintü megélhetésének, míg a volt szocialista országokban legalább a harmadát (10. táblázat).

A mediterrán országok körében legkedvezőbb a helyzet Portugáliában, ahol a legkisebb ökonómiai méretkategóriába tartozó gazdaságok átlagosan a szegénységi küszöbérték harmadát állították elő 2010-ben, mert a déli országok körében itt volt legalacsonyabb a szegénységi küszöb értéke, 5,2 ezer euró. Görögországban és Spanyolországban az ott érvényes szegénységi küszöbérték negyedét, Olaszországban hatodát állították elő a kisgazdaságok. Franciaországban a legmagasabb a szegénységi küszöbérték, így itt a legkisebb gazdaságokban előállított STÉ csak hetede a 2010. évre megállapított francia szegénységi küszöbértéknek.

A volt szocialista országok körében a szegénységi küszöbérték alacsony volta eredményez kedvező helyzetet. A legkisebb gazdaságok alacsony STÉ-jük ellenére érdemben képesek hozzájárulni a megélhetéshez. A „legrosszabb helyzetben” lévő Szlovéniában is megtermelik a szegénységi küszöbérték harmadát, de Romániában ez az arány megközelíti a 85 százalékot. Bár Romániában a legalacsonyabb a kisgazdaságok STÉ-je, a szegénységi küszöb is itt a legalacsonyabb, míg Szlovéniában a magas küszöbérték a magas STÉ ellenére alacsony önellátási fokot tesz lehetővé. Bulgária és Lengyelország kisgazdaságai a minimális létfeltételhez szükséges összeg kétharmadát, Csehország, Szlovákia, Horvátország kisgazdaságai hozzávetőlegesen a felét állítják elő, és hasonló a helyzet Magyarországon is. 
Ezek az eredmények összhangban vannak Davidova et al. (2009) megállapításával, miszerint a kisgazdaságokban saját fogyasztásra előállított termékek szignifikánsan hozzájárulnak a háztartások jövedelméhez, különösen Romániában, Bulgáriában és Lengyelországban. Romániában a 4000 eurónál kevesebb STÉ-t előállító kisgazdaságok 95 százaléka önellátásra termel, és a gazdaságban előállított termékek vagy az ellenértékük a szerény jövedelemmel rendelkező háztartások számára nélkülözhetetlen.

A magyar kisgazdaságok STÉ-je a második legalacsonyabb, kétharmad része a többi ország átlagának, de a magyar szegénységi küszöbérték is a harmadik legalacsonyabb, alig fele a portugál, illetve ötöde a francia értéknek. Így lehet Magyarországon sokkal kedvezőbb a helyzet, mint a mediterrán országokban, de itt is csak a 44 százalékát állítják elő a kisgazdaságok a szegénységi küszöb értékének.

Megállapíthatjuk tehát, hogy a vizsgált országok körében a 4000 eurónál kevesebb STÉ-t elöállító gazdaságok önállóan elméletileg sem tartják el a legkisebb háztartást sem, jellemzően csak jövedelemkiegészítést nyújtanak a gazdálkodóknak. Ez a jövedelemkiegészítés azonban a posztszocialista országokban jóval nagyobb mértékü, mint az egyéb EU-tagállamokban, így kijelenthető, hogy míg Nyugat- és Dél-Európában inkább a hobbigazdálkodás kategóriához kapcsolódhat a 4000 euró STÉ alatti gazdaságok fenntartása, addig Közép- és Délkelet-Európában a háztartások egyik kulcsfontosságú, mással nem vagy csak nehezen helyettesíthető jövedelemszerző forrásának tekinthető a mezőgazdasági tevékenység. A posztszocialista országok további három csoportra bonthatók: Csehországra és Szlovákiára, ahol a kisgazdaságok alacsony súlya és kis darabszáma miatt e tevékenység nem játszik meghatározó szerepet a vidéki népesség zömének ellátásában, bár akiket érint, azok számára fontos tevékenység. Lengyelország, Horvátország, Szlovénia és Magyarország esetében az ilyen jellegü gazdaságok nagy száma és a gazdálkodásban betöltött szerepe (5-10-15 százalékos részarány a szántóterületből, állatállományból és a termelési értékből) megkerülhetetlenné teszi ezt a szegmenst, de a 4000 euró STÉ alatti üzemek alapvetően a vidéki népesség jelentős részének jövedelemkiegészítésében játszanak szerepet. A harmadik csoportba Románia és Bulgária tartozik, ahol nem csupán jövedelemkiegészítést, hanem akár fö jövedelemforrást jelent ez a tevékenység, ráadásul a mezőgazdasági összteljesítmény szempontjából is fontosak ezen kisgazdaságok, bár e teljesítmény szinte teljes egészében a háztartások belső fogyasztását szolgálja, így kulcsszerepet játszik a vidéki élelmiszer-fogyasztás megfelelő szinten tartásában. 


\section{A kisüzemek szerepe a hazai mezőgazdasági termelésben}

A fejezetben általános helyzetképet vázolunk a hazai üzemi szerkezetről, annak változásairól, majd a mezőgazdasági kisüzemek részletesebb bemutatására térünk ki.

A mezőgazdasági összeírások adatai alapján a mezőgazdasági tevékenységet folytató gazdaságok száma folyamatosan csökkenő, állapítja meg a KSH (2012). A vizsgálatok szerint a 2000 és 2010 közötti időszakban a gazdaságok számának eröteljes csökkenése főként az egyéni gazdaságukat tömegesen felszámolók miatt következett be, amit a gazdasági szervezetek számának növekedése érdemben még csak mérsékelni sem tudott.

A 2010. évi ÁMÖ adatai szerint közel 567 ezer egyéni gazdaság és 8,8 ezer gazdasági szervezet folytatott mezőgazdasági tevékenységet Magyarországon 2010-ben (11. táblázat).

11. táblázat: A gazdaságok számának alakulása, 1991-2010

ezer darab

\begin{tabular}{cccc}
\hline Év & Gazdasági szervezetek & Egyéni gazdaságok & Összes gazdaság \\
\hline 1991 & 2,6 & 1395,8 & 1398,3 \\
2000 & 8,4 & 958,5 & 966,9 \\
2003 & 7,8 & 765,5 & 773,4 \\
\hline 2005 & 7,9 & 706,9 & 714,8 \\
\hline 2007 & 7,4 & 618,7 & 626,1 \\
\hline 2010 & 8,8 & 566,6 & 575,4 \\
\hline & Változás: $1991=100,0$ & $-41,2$ \\
\hline
\end{tabular}

Forrás: A mezögazdaság fejlettségének regionális különbségei, KSH 2008.; ÁMÖ 2010.

A magyar mezőgazdaság üzemszerkezetét tekintve megállapítható, hogy az egyéni gazdaságok száma meredeken csökkent 1991 és 2010 között, míg a gazdasági szervezetek száma az ezredfordulót követően nem változott számottevően. A csökkenés elsősorban a kis, saját fogyasztásra termelő gazdaságok számában következett be. Ezzel összefüggésben a használt mezőgazdasági terület tekintetében az egyéni gazdaságoknál koncentráció, a gazdasági szervezeteknél pedig a koncentráció mérsékelt csökkenése tapasztalható (12. táblázat).

A gazdasági szervezetekkel kapcsolatban említést érdemel, hogy a 2000-es évek elején/közepén számos egyéni gazdaság, őstermelő, családi gazdaság alakult át kft. vagy bt. formába (a könnyebb hitelhez jutás reményében). Emiatt a korábban őstermelőként működő gazdálkodó is társas vállalkozásnak minősült, ami rendkívüli módon torzította a valós birtokviszonyokat, és ez az oka annak, hogy 1991-hez képest a gazdasági szervezetek száma csaknem megháromszorozódott az ezredfordulóra (Belyó, 2011).

Sok veszteséges egyéni gazdaság szüntette be mezőgazdasági tevékenységét 1991-2007 között. A tevékenység beszüntetésének leggyakoribb okai között az elöregedés, valamint az utódlás rendezetlensége szerepelt. Az állattenyésztés jövedelmezősége is rohamosan hanyatlott, negatív irányba fordult. A szomszédos országokból hazánkba érkező olcsó baromfi- és sertéshúsimport sem kedvezett a magyar állattartóknak. 
12. táblázat: A mezőgazdasági tevékenységet folytató gazdaságok száma és területi megoszlása, 2000, 2005, 2007, 2010

\begin{tabular}{|c|c|c|c|c|}
\hline \multirow[b]{2}{*}{ Megnevezés } & \multicolumn{4}{|c|}{ Mezőgazdasági tevékenységet folytató gazdaságok } \\
\hline & $\begin{array}{c}\text { száma, } \\
\text { ezer darab }\end{array}$ & $\begin{array}{l}\text { aránya, } \\
\text { százalék }\end{array}$ & $\begin{array}{c}\text { területe, } \\
\text { ezer ha }\end{array}$ & $\begin{array}{l}\text { aránya, } \\
\text { százalék }\end{array}$ \\
\hline \multicolumn{5}{|c|}{2000} \\
\hline Gazdaságok összesen & 966,9 & 100,0 & 6394,1 & 100,0 \\
\hline ebböl: gazdasági szervezet & 8,4 & 0,9 & 3779,8 & 59,1 \\
\hline egyéni gazdaság & 958,5 & 99,1 & 2614,3 & 40,9 \\
\hline \multicolumn{5}{|c|}{2005} \\
\hline Gazdaságok összesen & 714,8 & 100,0 & 5709,9 & 100,0 \\
\hline ebből: gazdasági szervezet & 7,9 & 1,1 & 3441,4 & 60,3 \\
\hline egyéni gazdaság & 706,9 & 98,9 & 2268,5 & 39,7 \\
\hline \multicolumn{5}{|c|}{2007} \\
\hline Gazdaságok összesen & 626,1 & 100,0 & 6003,5 & 100,0 \\
\hline ebből: gazdasági szervezet & 7,4 & 1,2 & 3740,7 & 62,3 \\
\hline egyéni gazdaság & 618,7 & 98,8 & 2262,8 & 37,7 \\
\hline \multicolumn{5}{|c|}{2010} \\
\hline Gazdaságok összesen & 575,4 & 100,0 & 5896,4 & 100,0 \\
\hline ebböl: gazdasági szervezet & 8,8 & 1,6 & 3648,5 & 61,9 \\
\hline egyéni gazdaság & 566,6 & 98,4 & 2247,9 & 38,1 \\
\hline
\end{tabular}

Forrás: ÁMÖ 2000.; GSZÖ 2005, 2007., ÁMÖ 2010. alapján AKI Vidékfejlesztési Kutatási Osztály

A 2010. évi általános mezőgazdasági összeírás (ÁMÖ) adatai alapján az egyéni gazdaságok kétharmada (65,3 százaléka) 2000 euró standard termelési értéknél kevesebbet állított elő, és csupán 9,5 százalékuk termelt 8000 euró STÉ felett 2010-ben. A legkisebb méretkategóriába tartozó gazdaságok zöme Szabolcs-Szatmár-Bereg, Bács-Kiskun és Pest megyében végzett mezőgazdasági tevékenységet. A legnagyobb méretkategóriába tartozó üzemek Bács-Kiskun, Békés és SzabolcsSzatmár-Bereg megyében müködtek (2. melléklet). A két köztes méretkategóriába sorolható gazdaságok többsége szintén Bács-Kiskun, Hajdú-Bihar és Szabolcs-Szatmár-Bereg megyékben végzett mezőgazdasági tevékenységet. Minden megyében a 2000 euró STÉ alatti egyéni gazdaságok vannak többségben, de kiugróan magas az arányuk Komárom-Esztergom megyében (75,63 százalék), Budapesten (75,32 százalék) és Veszprém megyében (75,14 százalék). A kisgazdaságok közül a fejlődőképesebb 2000-4000 euró STÉ kategóriába sorolt üzemek aránya a dél-dunántúli (Somogy és Tolna) és az alföldi megyékben (Hajdú-Bihar, Jász-Nagykun-Szolnok, Békés) volt az átlagnál (16,0 százalék) nagyobb arányú.

\section{A mezőgazdasági kisüzemek kibocsátása}

Annak érdekében, hogy a vizsgált kisgazdaságok ágazati teljesítményét értékelni tudjuk, a továbbiakban méretkategóriák szerint tekintjük át a gazdaságok kibocsátásának, átlagos kibocsátásának és földterületre vetített kibocsátásának alakulását (13. táblázat). A 2000 euró standard termelési értéknél kevesebbet előállító gazdálkodói csoportot 382372 gazdaság alkotja (1. méretkategória), ami a teljes alapsokaság 66,3 százaléka. A hazai üzemszerkezet vonatkozásában ez a magas arány azt jelenti, hogy döntő többségben kisgazdaságok vannak jelen az ágazatban, ami az oly gyakran hangoztatott kétpólusú üzemszerkezet (Kapronczai, 2011; Tóth, 2014) meglétét támasztja alá. ${ }^{9}$

\footnotetext{
9 A kétpólusú üzemszerkezet már az 1960-as években létrejött, ám a háztáji kiterjesztésével csak még hangsúlyosabbá vált a bipoláris jelleg. Az elmúlt évtizedekben erősödött valamennyit a „közép”, de a kétpólusosság még mindig jelen van, és az uniós csatlakozás után sem változott jelentősebben.
} 
Kibocsátásuk 72293269 ezer forint volt 2010-ben, ami az összes gazdaság kibocsátásának csupán töredékét, 5,4 százalékát tette ki. Éves átlagkibocsátásuk megközelítette a 190 ezer forintot, a földterületre vetített kibocsátásuk pedig 418,6 ezer forint volt hektáronként. A kibocsátás nagyságrendjéből látszik, hogy ebben az esetben nem valódi árutermelö gazdaságokról van szó, hanem zömében olyan üzemekről, amelyek az egyszerre letermő növényeket (gabonát, zöldséget, gyümölcsöt) - nem lévén mód a tárolásukra és a folyamatos elfogyasztásukra - értékesítik és nem hagyják veszendőbe menni.

A második méretkategóriába (2000-4000 euró STÉ között) tartozó gazdaságok a teljes alapsokaság 15,3 százalékát teszik ki, ami 88237 gazdaságot jelent. A csoportba tartozó gazdaságok kibocsátása a teljes alapsokaságnak 4,7 százaléka, átlagkibocsátásuk 720 ezer forintra tehető, a földterületre vetített kibocsátásuk hektáronként 452,9 ezer forint. A második méretkategóriába tartozó gazdaságokra is igazak a legkisebbeket jellemző megállapítások: itt sem rendszeres árutermelő gazdálkodásról van szó, hanem sokkal inkább a családi fogyasztási szükségletek kielégítéséről és szerény mértékü többletjövedelem realizálásáról. Azonban a második méretkategóriába tartozó gazdaságok körében már igény mutatkozik a többletjövedelem visszaforgatására a gazdaságba, azaz jelentékeny fejlődési/fejlesztési potenciállal rendelkeznek.

\section{3. táblázat: A kibocsátás alakulása méretkategóriák szerint, 2010}

\begin{tabular}{lccc}
\hline \multicolumn{1}{c}{ Megnevezés } & $\begin{array}{c}\text { Kibocsátás, } \\
\text { ezer HUF }\end{array}$ & $\begin{array}{c}\text { Átlagkibocsátás, } \\
\text { ezer HUF }\end{array}$ & $\begin{array}{c}\text { Földterületre } \\
\text { vetített kibocsátás, } \\
\text { ezer HUF/ha }\end{array}$ \\
\hline 2000 euró STÉ alatt & 72293269,0 & 189,1 & 418,6 \\
\hline 2000-4000 euró STÉ között & 63230776,9 & 716,6 & 452,9 \\
\hline 4000-8000 euró STÉ között & 66150595,9 & 1448,5 & 295,5 \\
\hline 8000 euró STÉ felett & 1143033334,0 & 18960,5 & 280,4 \\
\hline
\end{tabular}

Forrás: ÁMÖ 2010 alapján AKI Vidékfejlesztési Kutatási Osztály

A 4000-8000 euró standard termelési értéket előállító gazdaságok (3. méretkategória) a teljes alapsokaságnak 8 százalékát (7,92 százalék) adják, mezőgazdasági kibocsátásuk pedig annak 4,9 százaléka. A 4000-8000 euró STÉ közötti kategóriában a földterületre vetített kibocsátás jelentősen csökkent a megelőző két (kisebb) méretkategóriához képest, ami egyfajta extenzifikációt jelent. A legnagyobb méretü (4. méretkategória), 8000 euró standard termelési értéknél többet elöállító gazdálkodói csoportot 60285 gazdaság alkotja, ami a teljes alapsokaságnak nagyjából egytizede. Többségük olyan specializált árutermelö üzem, amelyek az ágazat összteljesítményében jelentős szerepet töltenek be. Éles határvonal húzható a 8000 euró STÉ alatti és feletti gazdaságok között. Felette egyértelmüen fóállásban végzett, hatékony, magas eszközlekötéssel jellemezhető mezőgazdasági termelésről van szó; alatta pedig kisegítő, kiegészítő jellegű termelésről, ami elsősorban termékkínálatában tér el a professzionális árutermelő üzemektől.

\section{A mezőgazdasági kisüzemek földhasználata}

Ebben a részfejezetben a mezőgazdasági kisüzemek földhasználatának alakulását vizsgáljuk méretkategóriák szerinti bontásban. Elöljáróban megjegyezzük, hogy az elmúlt évek statisztikái alapján az egy gazdaságra jutó átlagos szántóterület nagysága a gazdasági szervezeteknél csökkenő, az egyéni gazdaságoknál pedig növekvő tendenciát mutat. A 14. táblázat adatai alapján jól látható, hogy a legnagyobb méretü gazdaságok mủvelik meg a legnagyobb földterületet: az egy gazdaságra jutó átlagos földterület esetükben megközelíti a 40 hektárt (38,7 hektár). 
A legkisebb méretkategóriába tartozó gazdaságok (2000 euró STÉ alatt) által megművelt átlagos földterület 0,8 hektár, ami csak szerény mértékben képes hozzájárulni a családi igények kielégítéséhez. A második és harmadik méretkategóriába tartozó gazdaságok által megmủvelt átlagos földterület 1,4, illetve 4,6 hektár, ami a családi igények kielégítésén túl a megtermelt és el nem fogyasztott termékek piacra juttatásával többletjövedelmet is generálhat.

14. táblázat: A földhasználat alakulása méretkategóriák szerint, 2010

\begin{tabular}{lccc}
\hline \multicolumn{1}{c}{ Megnevezés } & $\begin{array}{c}\text { Földterület, } \\
\text { ha }\end{array}$ & $\begin{array}{c}\text { Átlagos földterület, } \\
\text { ha }\end{array}$ & $\begin{array}{c}\text { Földterületre } \\
\text { vetített állatlétszám, } \\
\text { számosállat/ha }\end{array}$ \\
\hline 2000 euró STÉ alatt & 172711,3 & 0,8 & 1,03 \\
\hline 2000-4000 euró STÉ között & 139615,7 & 1,4 & 1,09 \\
\hline 4000-8000 euró STÉ között & 223852,1 & 4,6 & 0,50 \\
\hline 8000 euró STÉ felett & 4076116,2 & 38,7 & 0,50 \\
\hline
\end{tabular}

Forrás: ÁMÖ 2010 alapján AKI Vidékfejlesztési Kutatási Osztály

A földterületre vetített állatlétszámot tekintve a két legkisebb méretkategóriába tartozó gazdaságcsoport esetében a legmagasabb a fajlagos mutató értéke, ami azt jelzi, hogy a „kicsik” körében még mindig nagyobb hagyománya van az állattartásnak, mint a „nagyoknál”. Ehhez a megállapításhoz azonban azt is hozzátehetjük, hogy a statisztika szerint az állattartó egyéni gazdaságok és gazdasági szervezetek száma is csökkenő tendenciát mutat.

Az egyéni gazdaságok által használt mezőgazdasági terület kicsivel több mint 2400 ezer hektár volt 2010-ben, amelynek 12,4 százaléka (299,3 ezer hektár) volt a 4000 euró alatti STÉ méretkategóriába tartozó gazdaságok müvelésében, míg a legnagyobb (8000 STÉ fölötti) gazdaságok a földterület megközelítőleg 80 százalékát (1905,0 ezer hektár) használták. A legkisebb méretkategóriába tartozó egyéni gazdaságok átlagosan 0,4-0,5 hektár mezőgazdasági területet müveltek 2010ben, a legnagyobb méretkategóriába tartozók pedig átlagosan 35 hektáros mezőgazdasági területen gazdálkodtak.

A 4000 euró STÉ alatti kisgazdaságok Budapesten, illetve Pest, Nógrád és Szabolcs-SzatmárBereg megyében részesednek legnagyobb arányban (16 százalék felett) az ország mezőgazdasági területéből, legkisebb mértékben ( 8 százalék alatt) pedig Fejér, Tolna és Jász-Nagykun-Szolnok megyében (5. ábra). A statisztikai adatok szerint a legkisebb, 2000 euró STÉ alatti egyéni gazdaságok aránya Komárom-Esztergom (75,63 százalék), Veszprém (75,14 százalék) és Nógrád megyében (75,04 százalék), valamint Budapesten (75,31 százalék) a legmagasabb (3. melléklet). A 8000 euró STÉ feletti gazdaságok legnagyobb arányban Csongrád (17,00 százalék), Békés (14,10 százalék) és Bács-Kiskun megyében (13,77 százalék) vannak jelen a mezőgazdasági termelésben. 


\section{5. ábra: A 4000 euró STÉ alatti egyéni gazdaságok számának aránya és mezőgazdasági területből való részesedése}

A 4000 euró STÉ alatti egyéni gazdaságok által használt mezőgazdasági terület részesedése az ország összes mezőgazdasági területéből

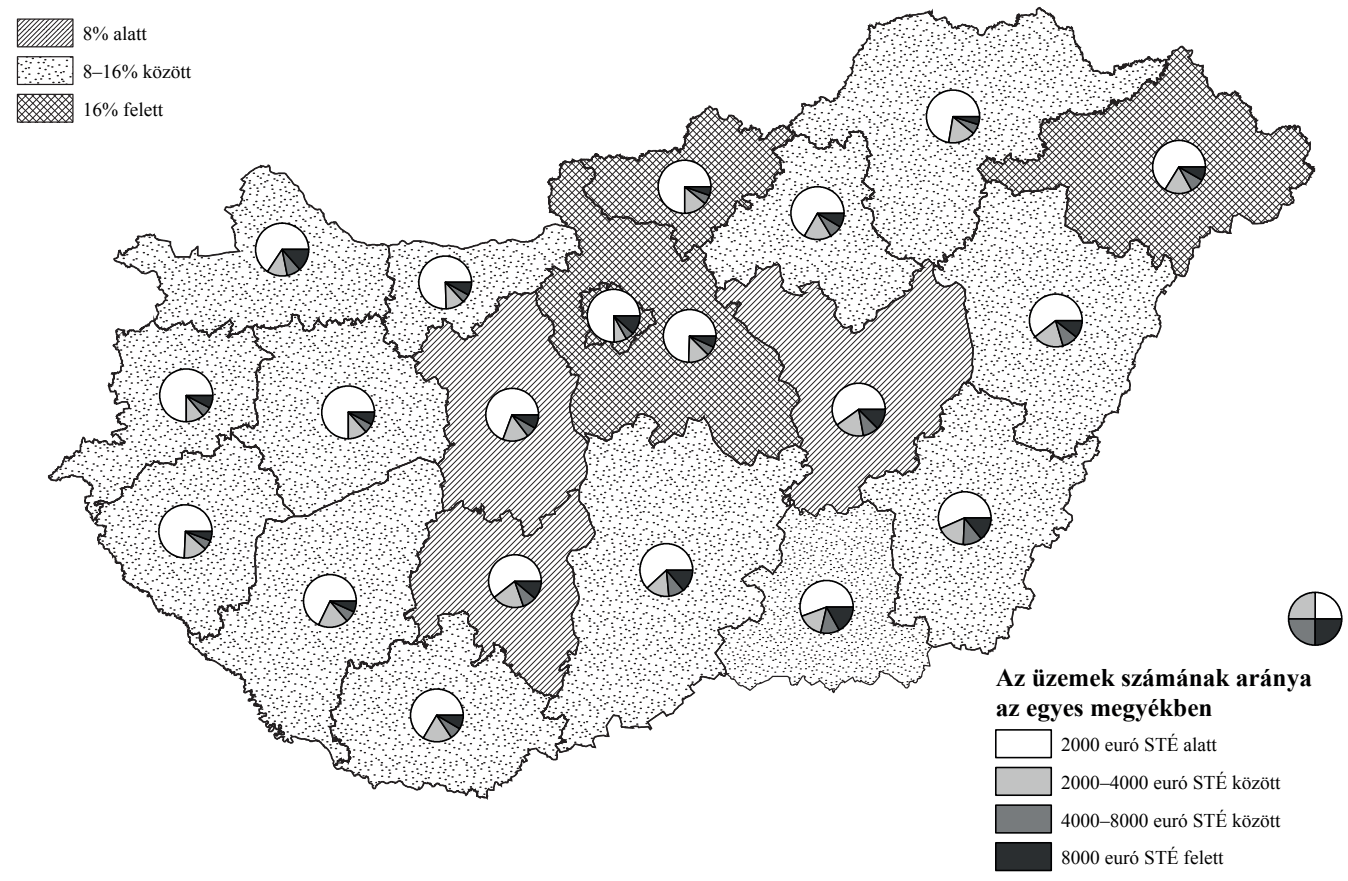

Forrás: ÁMÖ 2010 alapján AKI Tesztüzemi Információs Osztály

\section{A mezőgazdasági kisüzemek állatállománya}

A 2000 euró standard termelési érték alatt teljesítő kisüzemek által tartott állatállomány (178 337,4 számosállat) csupán egytizede a legnagyobb méretkategóriájú gazdaságok által tartott állománynak (2 038 089,0 számosállat) (15. táblázat). A statisztikai adatok szerint a gazdasági szervezetek által tartott állatállomány nagysága évek óta változatlan, ellenben az egyéniek állattartása csökkenő tendenciát mutat. Az állattartást jellemző magas kockázat miatt jövedelmező tevékenységet csak megfelelő szintű szaktudás mellett, jelentős számú állandó munkaerővel lehet végezni, ami nem minden esetben áll a gazdaságok rendelkezésére.

15. táblázat: Az állatlétszám alakulása méretkategóriák szerint, 2010

\begin{tabular}{lccc}
\hline \multicolumn{1}{c}{ Megnevezés } & $\begin{array}{c}\text { Állatlétszám, } \\
\text { számosállat }\end{array}$ & $\begin{array}{c}\text { Átlagos állatlétszám, } \\
\text { számosállat }\end{array}$ & $\begin{array}{c}\text { Munkaeróre vetített } \\
\text { állatlétszám, } \\
\text { számosállat/ÉME }\end{array}$ \\
\hline 2000 euró STÉ alatt & 178337,4 & 0,3 & 1,03 \\
\hline 2000-4000 euró STÉ között & 151928,8 & 1,8 & 2,6 \\
\hline 4000-8000 euró STÉ között & 112820,6 & 2,7 & 2,8 \\
\hline 8000 euró STÉ felett & 2038089,0 & 19,5 & 12,9 \\
\hline
\end{tabular}

Forrás: ÁMÖ 2010 alapján AKI Vidékfejlesztési Kutatási Osztály 
A legkisebb méretkategóriába tartozó kisüzemek jellemzően néhány baromfit, 1-2 sertést, esetleg szarvasmarhát tartanak. E gazdaságok zömében a család fogyasztását elégítik ki, eladásra szinte egyáltalán nem termelnek. Ellenben a nagyobb méretü gazdaságokban az esetek többségében nagy léptékü állattartás folyik és kiépített piaci kapcsolatokkal rendelkeznek, így folyamatosan értékesíteni tudják a végterméket. Az egyéni gazdaságok 65 százaléka tartott állatot 2010-ben, ami közel 380 ezer gazdaságot jelent. Az állattartó egyéni gazdaságok 60 százaléka termelt 2000 euró STÉ alatt. Ezt meghaladó volt az állattartó kisgazdaságok aránya Pest és Nógrád megyében. A 2. méretkategóriába tartozó gazdaságok körében is népszerü volt az állattartás, különösen a Dél-Dunántúlon, valamint Borsod-Abaúj-Zemplén megyében (4. melléklet).

\section{A mezőgazdasági kisüzemek munkaerő-lekötése}

A mezőgazdasági tevékenység végzésére nagyjából 440 ezer éves munkaerőegységnek (ÉME) megfelelő munkaegységet fordítottak a gazdaságokban 2010-ben, amelynek 18 százaléka a gazdasági szervezetek, 82 százaléka az egyéni gazdaságok mezőgazdasági tevékenységéhez kapcsolódott (KSH, 2011a). Az egyéni gazdaságok munkaerő-ráfordítása kettős szerkezetű. A mezőgazdasági tevékenységet ugyanis nem fizetett munkaerö - a családtagok - végzi, de a családi gazdaságokban is foglalkoztatnak időszakosan alkalmazottakat (fizetett munkaerö). A munkaerö-lekötést tekintve jól látható, hogy a legkisebb méretkategóriába tartozó gazdaságok munkaerö-lekötése volt a legmagasabb 2010-ben, ennek ellenére a munkaerőre vetített kibocsátásuk nem érte el az 500 ezer forintot sem éves munkaerőegységenként (16. táblázat).

\section{6. táblázat: A munkaerő-lekötés alakulása méretkategóriák szerint, 2010}

\begin{tabular}{lccc}
\hline \multicolumn{1}{c}{ Megnevezés } & $\begin{array}{c}\text { Munkaer"-lekötés, } \\
\text { ÉME }\end{array}$ & $\begin{array}{c}\text { Átlagos } \\
\text { munkaéó-lekötés, } \\
\text { ÉME }\end{array}$ & $\begin{array}{c}\text { Munkaeróre vetített } \\
\text { kibocsátás, } \\
\text { ezer HUF/ÉME }\end{array}$ \\
\hline 2000 euró STÉ alatt & 173175,3 & 0,5 & 417,5 \\
\hline 2000-4000 euró STÉ között & 57882,5 & 0,7 & 1092,4 \\
\hline 4000-8000 euró STÉ között & 40780,5 & 0,9 & 1622,1 \\
\hline 8000 euró STÉ felett & 158400,8 & 1,8 & 7216,1 \\
\hline
\end{tabular}

Forrás: ÁMÖ 2010 alapján AKI Vidékfejlesztési Kutatási Osztály

A legmagasabb munkaerőre vetített kibocsátással a 8000 euró STÉ feletti gazdaságok rendelkeztek 2010-ben, ám munkaerő-lekötésük kisebb volt, mint a 2000 euró STÉ-vel rendelkező üzemeké. Általánosságban elfogadott, hogy a technikai fejlődés munkaerö-megtakarítással jár együtt, amely inkább a nagyobb gazdaságokban valósul meg (Nagy, 2011). Az egyéni gazdaságokban ledolgozott munkaórák száma 361992 ÉME volt 2010-ben, amiből legnagyobb mértékben a Bács-Kiskun megyei (40 923 ÉME), a Szabolcs-Szatmár-Bereg megyei (38 879 ÉME) és a Pest megyei (29 209 ÉME) egyéni gazdaságok részesedtek (5. melléklet). Az észak-alföldi és a dél-alföldi megyékben nemcsak a 2000 euró STÉ alatti egyéni gazdaságok munkaerő-lekötése volt jelentős, hanem a 8000 euró STÉ feletti gazdaságoké is. Mindez azt mutatja, hogy az Alföld mezőgazdasági jellege az ország többi tájegységéhez képest még mindig erőteljesebb.

A 4000 euró STÉ méretű egyéni gazdaságokhoz köthető nem fizetett munkaerő aránya Nógrád, Borsod-Abaúj-Zemplén, valamint Zala megyében a legnagyobb (80 százalék fölötti), ezzel szemben Csongrád, Bács-Kiskun és Békés megyében az összes mezőgazdaságban felhasznált nem fizetett munkaerőnek csak bő fele köthető a kisüzemi méretű egyéni gazdaságokhoz (6. ábra). 


\section{6. ábra: A 4000 euró STÉ alatti egyéni gazdaságok részesedése a mezőgazdaságban hasznosított nem fizetett munkaerőből}

\section{A 4000 euró STÉ alatti kisüzemekhez köthető nem fizetett munkaerő aránya}

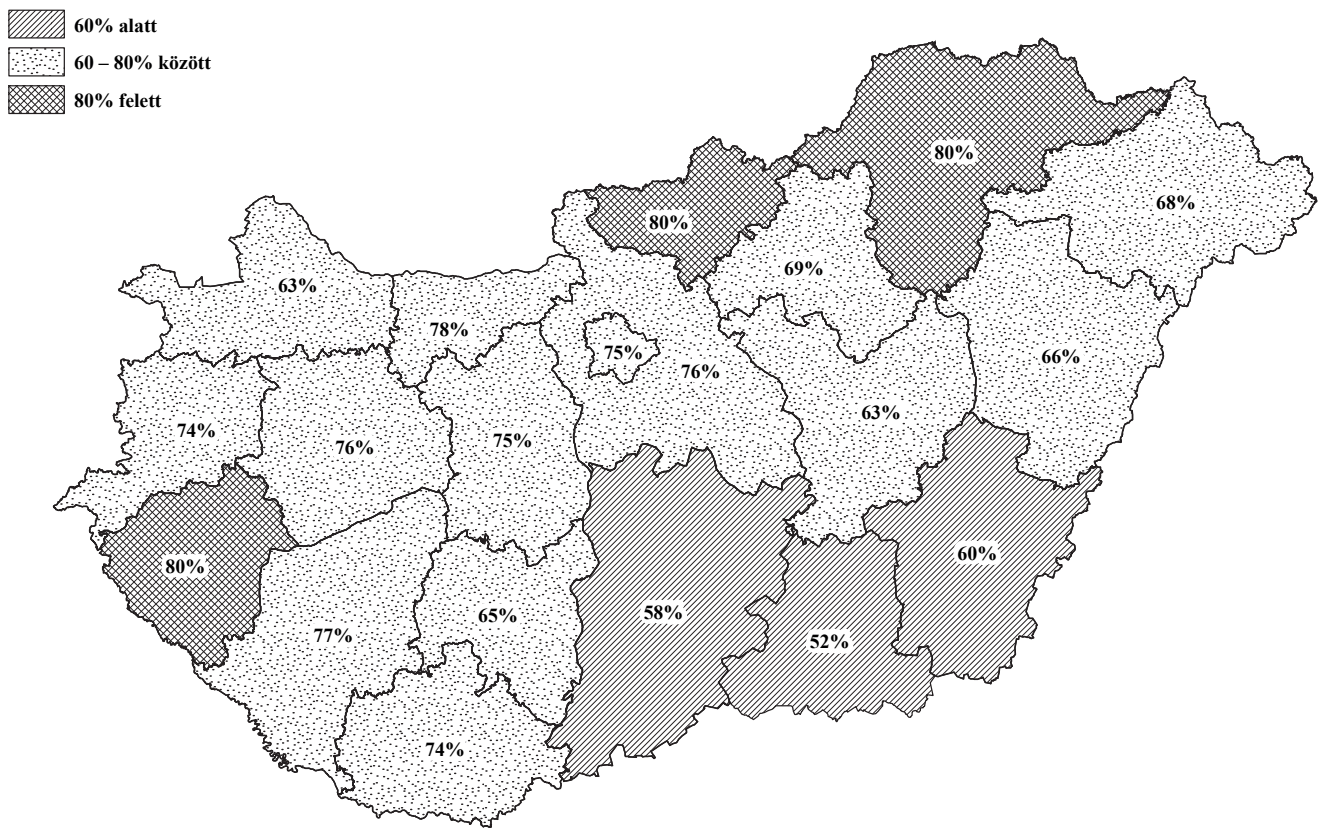

Forrás: ÁMÖ 2010 alapján AKI Tesztüzemi Információs Osztály

A fejezet célja az volt, hogy betekintést adjon a mezőgazdasági kisüzemek gazdálkodásába azok kibocsátásán, földhasználatán, állattartásán és munkaerö-lekötésén keresztül. A statisztikai adatok alapján az az álláspontunk, hogy a 8000 euró standard termelési érték alatt teljesítő kisüzemek „félállásnak" minősülnek, illetve a szociális transzfereket egészítik ki. Ez azt jelenti, hogy a mezőgazdasági tevékenységből származó jövedelem ebben a méretkategóriában nem elegendő egy főállású munkahely fenntartásához. A 8000 euró standard termelési értéknél többet elöállító gazdaságok ugyanakkor már képesek egy fóállásnak minősülő, a családi igények biztonságos és folyamatos kielégítését lehetővé tevő munkahely fenntartására, és ezzel összefüggésben jelentős fejlődési potenciál is rejlik bennük. 



\section{A kistermelök föbb szociodemográfiai jellemzői}

A fejezetben a 2010. évi általános mezőgazdasági összeírás adatai alapján az egyéni gazdaságok, köztük a 4000 euró STÉ alatti kisüzemek gazdaságvezetőinek szociodemográfiai jellemzőit (nem, életkor, szakképzettség, gazdasági aktivitás, kiegészítő jövedelemszerzés) tekintjük át.

\section{Nemek szerinti jellemzők}

A 2010. évi összeírás során regisztrált közel 568 ezer egyéni gazdaságból mintegy 150 ezer gazdaság vezetője volt nő (17. táblázat). A nők mezőgazdaságban való részvétele azonban ennél jóval nagyobb arányú, tekintettel arra, hogy a gazdaságok munkájában inkább segítő családtagként és nem gazdaságvezetőként működnek közre. Ezt támasztja alá, hogy 2010-ben a gazdaságvezetőkön felül további 379,4 ezer nő, valamint 129,8 ezer férfi végzett munkát segítő családtagként a regisztrált egyéni gazdaságokban (KSH, 2011a).

17. táblázat: A gazdaságvezető neme és az STÉ-kategóriák szerinti jellemzők, 2010

\begin{tabular}{lrrrrrr}
\hline \multirow{2}{*}{\multicolumn{1}{c}{ Megnevezés }} & \multicolumn{2}{c}{ Nó } & \multicolumn{2}{c}{ Férfi } & \multicolumn{2}{c}{ Összes } \\
\cline { 2 - 7 } & \multicolumn{1}{c}{ darab } & százalék & darab & százalék & darab & százalék \\
\hline 2000 euró STÉ alatt & 112627 & 29,6 & 267505 & 70,4 & 380132 & 100 \\
\hline 2000-4000 euró STÉ & 20819 & 23,7 & 67061 & 76,3 & 87880 & 100 \\
\hline 4000-8000 euró STÉ & 8311 & 18,4 & 36822 & 81,6 & 45133 & 100 \\
\hline 8000 euró STÉ felett & 8258 & 15,2 & 46226 & 84,8 & 54484 & 100 \\
\hline Összes & 150015 & 26,4 & 417614 & 73,6 & 567629 & 100 \\
\hline
\end{tabular}

Forrás: ÁMÖ 2010 alapján AKI Vidékfejlesztési Kutatási Osztály

A vizsgálat fókuszterületét képező 4000 euró STÉ alatti méretkategóriába tartozó 468 ezer egyéni gazdaság közel kétharmadát férfi, harmadát női üzemvezető irányította (18. táblázat). Az üzemek gazdasági teljesítményét kifejező standard termelési érték, valamint a gazdaságvezető neme szerinti összefüggéseket vizsgálva az is megállapítható, hogy a magasabb STÉ-kategóriába tartozó üzemekben a női gazdaságvezetők aránya csökkenő. Míg a legkisebb (2000 euró STÉ alatti) méretkategóriájú gazdaságok közel harmadát (29,6 százalék) irányította nő, az árutermelő léptékü, 8000 euró STÉ fölötti méretü gazdaságoknak mindössze 15,2 százalékát.

18. táblázat: A gazdaságvezető neme és az STÉ-kategóriák szerinti jellemzők, 2010

\begin{tabular}{llrrrrr}
\hline \multirow{2}{*}{ Megnevezés } & Mértékegység & $\begin{array}{c}\text { <2000 euró } \\
\text { STÉ }\end{array}$ & $\begin{array}{c}\text { 2000-4000 } \\
\text { euró STÉ }\end{array}$ & $\begin{array}{c}\text { 4000-8000 } \\
\text { euró STÉ }\end{array}$ & $\begin{array}{c}\text { >8000 euró } \\
\text { STÉ }\end{array}$ & Összes \\
\hline \multirow{2}{*}{ Nó } & száma, darab & 112627 & 20819 & 8311 & 8258 & 150015 \\
\cline { 2 - 8 } & aránya, százalék & 75,1 & 13,9 & 5,5 & 5,5 & 100 \\
\hline \multirow{2}{*}{ Férfi } & száma, darab & 267505 & 67061 & 36822 & 46226 & 417614 \\
\cline { 2 - 7 } & aránya, százalék & 64,1 & 16,1 & 8,8 & 11,1 & 100 \\
\multirow{2}{*}{ Összes } & száma, darab & 380132 & 87880 & 45133 & 54484 & 567629 \\
\cline { 2 - 7 } & aránya, százalék & 67,0 & 15,5 & 8,0 & 9,6 & 100 \\
\hline
\end{tabular}

Forrás: ÁMÖ 2010 alapján AKI Vidékfejlesztési Kutatási Osztály 
A gazdaságvezető neme, a termelési cél, valamint a standard termelési érték együttes vizsgálata megerősíti, hogy a nők részvételi aránya a nagyobb STÉ-kategóriákban jóval kisebb (6. melléklet). Az egyes STÉ-kategóriák termelési cél szerinti belső megoszlását vizsgálva az is megállapítható, hogy a nők körében a férfiakhoz viszonyítva valamennyi kategóriában kicsivel nagyobb a magukat értékesítésre termelőként azonosító gazdaságvezetők aránya. A nagyobb méretkategóriákban a különbségek kifejezettebbek. Ez alapján arra következtethetünk, hogy a női gazdaságvezetők számára az előállított mezőgazdasági termékek értékesítése - lényegében az STÉ-méretkategóriától függetlenül - háztartásuk bevételeit tekintve számottevő jövedelmet eredményez.

\section{Korszerkezeti jellemzők}

A 2010. évi ÁMÖ ugyan a gazdaságvezetők életkor szerinti jellemzőinek részletesebb elemzését a korcsoportonként összevont adatok miatt csak korlátozottan teszi lehetővé, a hazai gazdatársadalom korszerkezeti jellemzői így is jól kirajzolódnak. ${ }^{10} \mathrm{Az}$ összes egyéni gazdaság közel harmadát irányította 2010-ben olyan gazdálkodó, aki betöltötte a 65. életévét, ettől nem sokkal maradt el az 55-64 éves korosztályhoz tartozó gazdaságvezetők aránya (27,9 százalék). A közel 568 ezer egyéni gazdaságból mindössze 3,8 ezer üzemet (az összes gazdaság 0,7 százalékát) vezetett 25 év alatti fiatal. A 25-34 éves korosztályhoz majdnem tízszer annyi egyéni gazdaság tartozott, a közbenső kategóriákba (a 35-44, illetve a 45-54 éves korosztályhoz) az egyéni gazdaságok bő harmadát sorolták.

19. táblázat: A gazdaságvezető életkora és az STÉ szerinti jellemzők, 2010

\begin{tabular}{|c|c|c|c|c|c|c|}
\hline Megnevezés & Mértékegység & $\begin{array}{c}<2000 \text { euró } \\
\text { STÉ }\end{array}$ & $\begin{array}{c}\text { 2000-4000 } \\
\text { euró STÉ }\end{array}$ & $\begin{array}{c}\text { 4000-8000 } \\
\text { euró STÉ }\end{array}$ & $\begin{array}{c}>8000 \text { euró } \\
\text { STÉ }\end{array}$ & Összes \\
\hline \multirow{2}{*}{25 év $\leq$} & száma, darab & 2755 & 482 & 258 & 336 & 3831 \\
\hline & aránya, százalék & 71,9 & 12,6 & 6,7 & 8,8 & 100 \\
\hline \multirow{2}{*}{ 25-34 éves } & száma, darab & 24391 & 4693 & 2610 & 4199 & 35893 \\
\hline & aránya, százalék & 68,0 & 13,1 & 7,3 & 11,7 & 100 \\
\hline \multirow{2}{*}{ 35-44 éves } & száma, darab & 53266 & 12033 & 6835 & 9837 & 81971 \\
\hline & aránya, százalék & 65,0 & 14,7 & 8,3 & 12,0 & 100 \\
\hline \multirow{2}{*}{ 45-54 éves } & száma, darab & 75666 & 17978 & 10522 & 14757 & 118923 \\
\hline & aránya, százalék & 63,6 & 15,1 & 8,9 & 12,4 & 100 \\
\hline \multirow{2}{*}{ 55-64 éves } & száma, darab & 102506 & 25663 & 13674 & 16278 & 158121 \\
\hline & aránya, százalék & 64,8 & 16,2 & 8,6 & 10,3 & 100 \\
\hline \multirow{2}{*}{65 éves $\geq$} & száma, darab & 121548 & 27031 & 11234 & 9077 & 168890 \\
\hline & aránya, százalék & 72,0 & 16,0 & 6,6 & 5,4 & 100 \\
\hline \multirow{2}{*}{ Összes } & száma, darab & 380132 & 87880 & 45133 & 54484 & 567629 \\
\hline & aránya, százalék & 67,0 & 15,5 & 8 & 9,6 & 100 \\
\hline
\end{tabular}

Forrás: ÁMÖ 2010 alapján AKI Vidékfejlesztési Kutatási Osztály

Az STÉ-méretkategóriák szerinti jellemzőket vizsgálva szembetűnő, hogy a legfiatalabb és a legidősebb gazdák körében átlag fölötti a 2000 euró STÉ alatti és átlag alatti az árutermelői léptékű, 8000 euró STÉ fölötti gazdaságok aránya (19. táblázat). Ennek vélhetően az az oka, hogy a fiatalabb korosztályhoz tartozók még nem halmoztak fel számottevő termelési erőforrást, a 65 évesnél idősebb korosztály körében pedig jelentős számban fordulnak elő olyanok, akik már csak nyugdíjuk kiegészítésére, fogyasztási szükségleteik kielégítésére foglalkoznak kisléptékü mezőgazdasági tevékenységgel (7. melléklet).

\footnotetext{
10 A KSH hat korcsoportra bontva (25 év alattiak, 25-34 éves, 35-44 éves, 45-54 éves, 55-64 éves, 65 évesnél idősebb) közli az összeírt egyéni gazdaságok vezetöinek életkor szerinti adatait.
} 
Az ÁMÖ adatai alapján az is megállapítható, hogy a kisüzemi gazdaságok vezetőinek korszerkezete jelentős, az adott térség mezőgazdasági adottságaival, a foglalkoztatás, jövedelemszerzés helyi lehetőségeivel összefüggő sajátosságokat mutat. Fiatalos korszerkezet a leghátrányosabb helyzetü kistérségek körébe tartozó Bodrogközi, Csengeri, Derecske-Létavértesi, Kunszentmiklósi, Nyírbátori, Sellyei, Szeghalomi, Tokaji és Törökszentmiklósi kistérségeket jellemzi, ahol a 35 évesnél fiatalabb gazdaságvezetők összes kisüzemi gazdaságvezetőhöz viszonyított aránya eléri a 10 százalékot. A 65 év feletti gazdaságvezetők aránya Budapest mellett a Vas megyében elhelyezkedő Öriszentpéteri kistérségben, valamint a Bélapátfalvai és Pétervásárai kistérségben a legnagyobb, 40 százalékot meghaladó. A kisüzemek humánerőforrás-ellátottsága szempontjából fontos összefüggés, hogy a gazdaságokhoz a gazdaságvezetőknél lényegesen kedvezőbb korszerkezetű segítő családtagok kapcsolódnak. A vizsgálat célcsoportját képező 4000 euró STÉ alatti üzemekben az összes regisztrált segítő családtag mintegy 77,4 százaléka (394 409 fó) dolgozott 2010-ben, akiknek közel negyede volt 35 évesnél fiatalabb, míg az aktív korosztályba (35-64 évesek) 61,8 százalékuk tartozott.

\section{Humántőke-ellátottság}

Számos nemzetközi és hazai tanulmány (Swinnen et al., 2013; Baptista, 2012; Dudek et al., 2014; Biró et al., 2016) megerősíti, hogy a magasabb szintű képzettség növeli az üzemek alkalmazkodóképességét, teljesítményét, ennek ellenére a gazdálkodók szakképzettségi szintje kimondottan alacsony. Az Európai Unió más tagországaihoz hasonlóan a hazai környezetben is a szakirányú képzettség nélküli, gyakorlati tapasztalat birtokában történő gazdálkodás a meghatározó. A 2010. évi mezőgazdasági összeírás szerint az összes egyéni gazdaság 86,3 százaléka támaszkodott gazdasága müködtetése során gyakorlati tapasztalatokra (20. táblázat). Alap-, illetve középszintü szakképzettséggel bő tizedük, felsőfokú végzettséggel alig 3 százalékuk rendelkezett.

\section{0. táblázat: A gazdaságvezetők jellemzői szakképzettség és STÉ szerint, 2010}

\begin{tabular}{lrrrrrrrrr}
\hline \multirow{2}{*}{ Megnevezés } & \multicolumn{2}{c}{$\begin{array}{c}\text { Gyakorlati } \\
\text { tapasztalat }\end{array}$} & \multicolumn{2}{c}{$\begin{array}{c}\text { Alap- vagy közép- } \\
\text { szintú }\end{array}$} & \multicolumn{2}{c}{ Felsófokú } & \multicolumn{2}{c}{ Összes } \\
\cline { 2 - 10 } & \multicolumn{1}{c}{ darab } & százalék & \multicolumn{1}{c}{ darab } & százalék & darab & százalék & darab & százalék \\
\hline 2000 euró STÉ alatt & 347518 & 91,9 & 25043 & 6,6 & 5429 & 1,4 & 377990 & 100 \\
\hline 2000-4000 euró STÉ & 75164 & 86,1 & 10288 & 11,8 & 1824 & 2,1 & 87276 & 100 \\
\hline 4000-8000 euró STÉ & 34286 & 76,6 & 8639 & 19,3 & 1859 & 4,2 & 44784 & 100 \\
\hline 8000 euró STÉ felett & 29936 & 55,4 & 18248 & 33,8 & 5848 & 10,8 & 54032 & 100 \\
\hline Összes & 486904 & 86,3 & 62218 & 11,0 & 14960 & 2,7 & 564082 & 100 \\
\hline
\end{tabular}

Forrás: ÁMÖ 2010 alapján AKI Vidékfejlesztési Kutatási Osztály

A kisüzemek fejlesztése szempontjából fontos összefüggés, hogy a kisebb méretkategóriájú gazdaságok körében az alapsokaság átlagánál jóval alacsonyabb a szakképzettséggel nem rendelkezö, gyakorlati tapasztalat birtokában gazdálkodó üzemvezetők aránya (8. melléklet). A tendenciát tekintve ugyanakkor a kisgazdaságok vezetőinek szakképzettsége terén javulás mutatkozik: a legalább alap- és középszintű végzettséggel rendelkező kisüzemek aránya a 2005-2010 közötti időszakban kétszeresére emelkedett, számuk bö 13 ezerrel bővült.

A kisüzemek vezetőinek szakképzettsége terén jelentős területi különbségek mutatkoznak. A legkedvezőbb képzettségi szerkezet Békés, Szabolcs-Szatmár-Bereg és Pest megyét jellemzi, ahol átlagosan a gazdaságvezetők 13-15 százaléka végzi a mezőgazdasági tevékenységet mezőgazdasági szakképzettség birtokában (7. ábra). A felsőfokú képzettséggel rendelkező gazdaságvezetők aránya Budapesten a legmagasabb, 2010-ben megközelítette a 8 százalékot. 


\section{7. ábra: A 4000 euró STÉ alatti gazdaságok képzettség és munkaerő-felhasználás szerinti jellemzői}

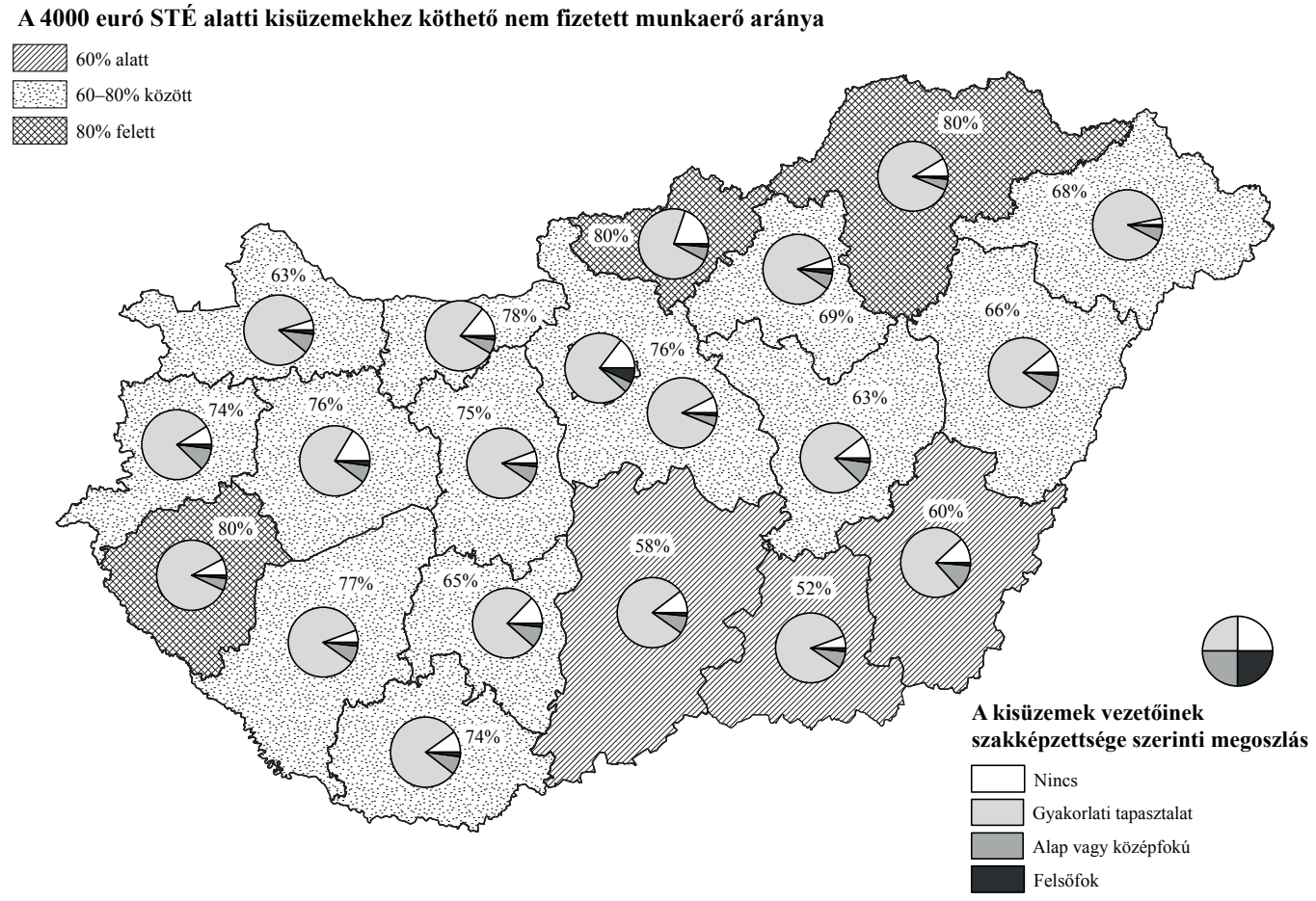

Forrás: ÁMÖ 2010 alapján AKI Tesztüzemi Információs Osztály, 2016

Az ÁMÖ adatai azt is alátámasztják, hogy az árutermelő egyéni gazdaságok a gazdálkodás hatékonyságának növelése érdekében nagyobb hajlandósággal ruháznak be a humán tőkébe, mint a zömmel jövedelemkiegészítés, saját fogyasztásra termelés céljából gazdálkodó kisüzemek. Míg a 2000 euró STÉ alatti méretű gazdaságok mindössze 4,5 százaléka, addig a 8000 euró STÉ fölötti kategóriába tartozó gazdaságok bő harmada vett részt az összeírás évében a gazdaság múködtetésében hasznosítható tanfolyami képzésen, míg a közbenső kategóriákban a részvételi aktivitás az átlag körül alakult (21. táblázat).

21. táblázat: Tanfolyami részvétel ${ }^{\text {a) }}$ és STÉ szerinti jellemzők, 2010

\begin{tabular}{lrccccc}
\hline \multirow{2}{*}{ Megnevezés } & \multicolumn{2}{c}{ Részt vett } & \multicolumn{2}{c}{ Nem vett részt } & \multicolumn{2}{c}{ Összes } \\
\cline { 2 - 7 } & darab & százalék & darab & százalék & darab & százalék \\
\hline 2000 euró STÉ alatt & 17095 & 4,5 & 360895 & 95,5 & 377990 & 100 \\
\hline 2000-4000 euró STÉ & 7432 & 8,5 & 79844 & 91,5 & 87276 & 100 \\
\hline 4000-8000 euró STÉ & 7416 & 8,5 & 37368 & 91,5 & 44784 & 100 \\
\hline 8000 euró STÉ felett & 19308 & 35,7 & 34724 & 64,3 & 54032 & 100 \\
\hline Összes & 51251 & 9,1 & 512831 & 90,9 & 564082 & 100 \\
\hline
\end{tabular}

a) Az ÁMÖ az elmúlt egy év vonatkozásában regisztrálja az elvégzett tanfolyamra vonatkozó adatokat.

Forrás: ÁMÖ 2010 alapján AKI Vidékfejlesztési Kutatási Osztály 
A képzettségre vonatkozó adatok részletesebb elemzése azt is megerősíti, hogy a gazdaságvezető humán tőkével való ellátottsága és a gazdálkodás eredményessége között összefüggés mutatkozik (22. táblázat). Míg a csak gyakorlati tapasztalattal rendelkező egyéni gazdálkodók 6,1 százaléka, az alap- vagy középszintű szakképzettséggel rendelkezők közel harmada, a felsőfokú végzettségüek majdnem 40 százaléka volt árutermelői léptékủ (8000 euró STÉ fölötti méretű) 2010-ben.

\section{2. táblázat: Mezőgazdasági szakképzettség és STÉ szerinti jellemzők, 2010}

\begin{tabular}{|c|c|c|c|c|c|c|}
\hline Megnevezés & Mértékegység & $\begin{array}{c}<2000 \text { euró } \\
\text { STÉ }\end{array}$ & $\begin{array}{c}2000-4000 \\
\text { euró STÉ }\end{array}$ & $\begin{array}{l}\text { 4000-8000 } \\
\text { euró STÉ }\end{array}$ & $\begin{array}{c}>8000 \text { euró } \\
\text { STÉ }\end{array}$ & Összes \\
\hline \multirow{2}{*}{$\begin{array}{l}\text { Gyakorlati } \\
\text { tapasztalat }\end{array}$} & száma, darab & 347518 & 75164 & 34286 & 29936 & 486904 \\
\hline & aránya, százalék & 71,4 & 15,4 & 7 & 6,1 & 100 \\
\hline \multirow{2}{*}{$\begin{array}{l}\text { Alap- vagy } \\
\text { középszintú }\end{array}$} & száma, darab & 25043 & 10288 & 8639 & 18248 & 62218 \\
\hline & aránya, százalék & 40,3 & 16,5 & 13,9 & 29,3 & 100 \\
\hline \multirow{2}{*}{ Felsőfokú } & száma, darab & 5429 & 1824 & 1859 & 5848 & 14960 \\
\hline & aránya, százalék & 36,3 & 12,2 & 12,4 & 39,1 & 100 \\
\hline \multirow{2}{*}{ Összes } & száma, darab & 377990 & 87276 & 44784 & 54032 & 564082 \\
\hline & aránya, százalék & 67,0 & 15,5 & 8 & 9,6 & 100 \\
\hline
\end{tabular}

Forrás: ÁMÖ 2010 alapján AKI Vidékfejlesztési Kutatási Osztály

A 4000 euró STÉ alatti kisüzemek árutermelővé fejlesztése szempontjából fontos összefüggés, hogy körükben több mint 7000 olyan gazdaság található, amelynek vezetője felsőfokú mezőgazdasági szakképzettséggel rendelkezett 2010-ben, további 35 ezer kisüzemet alap- vagy középszintü mezőgazdasági szakképzettségü gazda irányított. A gazdaságok humán tőkéjét közel 3 ezer felsőfokú végzettségü és 13 ezer alap- és középszintű mezőgazdasági szakképzettségü családtag gazdagította 2010-ben.

\section{Gazdasági aktivitás szerinti jellemzők}

A mezőgazdasági üzemek fejlesztési lehetőségeit meghatározzák a gazdaság müködtetésében közremüködők gazdasági aktivitás szerinti jellemzői is. Ez alapján a két legnagyobb létszámú csoportot a foglalkoztatottak és a nyugdíjasként gazdálkodók képezik. Előbbiek az egyéni gazdaságok 40 százalékát, utóbbiak közel felét tették ki 2010-ben (23. táblázat). A regisztrált egyéni gazdaságok közel 5 százalékát (mintegy 26,6 ezer gazdaságot) munkanélküli gazdaságvezetők müködtették, az anyasági ellátásban részesülök száma a 4000-hez közelített, a tanulói státuszban gazdálkodók száma megközelítette az ezret. A gazdaságvezetők 6,4 százaléka (mintegy 36,4 ezer gazdaság) ,egyéb módon" (pl. nem foglalkoztatott aktív korúként) gazdálkodott.

A gazdaságban munkát végzők gazdasági aktivitása a gazdaságvezetőkétől eltérő képet mutat. Körükben a gazdaságvezetőknél nagyobb a foglalkoztatottak, a tanulók, a munkanélküliek, illetve az egyéb módon gazdálkodók, és jóval kisebb a nyugdíjasok aránya. A mezőgazdaság megélhetési problémák mérséklésében betöltött jelentőségére utal, hogy 2010-ben összességében 60,5 ezer munkanélküli (a KSH által adott évben nyilvántartott munkanélküliek 12,5 százaléka) és 432,5 ezer nyugdíjas (az összes nyugdíjas, járadékos, nyugdíjszerü ellátásban részesülő 14,5 százaléka) kapcsolódott gazdaságvezetőként vagy a gazdaságban munkát végzőként az ágazathoz. 
23. táblázat: Az egyéni gazdaságok gazdasági aktivitás szerinti jellemzői, 2010

\begin{tabular}{lrrrrrr}
\hline \multirow{2}{*}{ Megnevezés } & \multicolumn{2}{c}{ Gazdaságvezetók } & \multicolumn{2}{c}{$\begin{array}{c}\text { Gazdaságban munkát } \\
\text { végzók }\end{array}$} & \multicolumn{2}{c}{ Összes } \\
\cline { 2 - 7 } & \multicolumn{1}{c}{ darab } & százalék & \multicolumn{1}{c}{ darab } & százalék & \multicolumn{1}{c}{ darab } & százalék \\
\hline Foglalkoztatott & 224764 & 39,6 & 217712 & 42,8 & 442476 & 41,1 \\
\hline Munkanélküli & 26640 & 4,7 & 33915 & 6,7 & 60555 & 5,6 \\
\hline Nyugdíjas & 274871 & 48,4 & 161654 & 31,7 & 436525 & 40,5 \\
\hline Anyasági ellátás & 3907 & 0,7 & 19247 & 3,8 & 23154 & 2,2 \\
\hline Tanuló & 848 & 0,1 & 34140 & 6,7 & 34988 & 3,2 \\
\hline Egyéb & 36416 & 6,4 & 42504 & 8,3 & 78920 & 7,3 \\
\hline Összes & 567446 & 100 & 509172 & 100 & 1076618 & 100 \\
\hline
\end{tabular}

Forrás: ÁMÖ 2010 alapján AKI Vidékfejlesztési Kutatási Osztály

A gazdasági aktivitás és a termelési érték összefüggéseit vizsgálva az is megállapítható, hogy a „foglalkoztatottak”, illetve az „egyéb módon” gazdálkodók körében a legnagyobb az árutermelői léptékü (4000 euró STÉ fölötti) üzemek előfordulása (24. táblázat). A gazdaságvezetői feladatokat foglalkoztatottként ellátók ötödének, az egyéb módon gazdálkodók bő harmadának mérete haladta meg 2010-ben az árutermelés küszöbét jelentő 4000 euró STÉ-t (9. melléklet).

24. táblázat: A gazdaságvezetők gazdasági aktivitás szerinti jellemzői, 2010

\begin{tabular}{|c|c|c|c|c|c|c|c|c|c|c|}
\hline \multirow{2}{*}{ Megnevezés } & \multicolumn{2}{|c|}{$\begin{array}{l}\text { <2000 euró } \\
\text { STÉ }\end{array}$} & \multicolumn{2}{|c|}{$\begin{array}{l}\text { 2000-4000 } \\
\text { euró STÉ }\end{array}$} & \multicolumn{2}{|c|}{$\begin{array}{l}\text { 4000-8000 } \\
\text { euró STÉ }\end{array}$} & \multicolumn{2}{|c|}{$\begin{array}{l}>8000 \text { euró } \\
\text { STÉ }\end{array}$} & \multicolumn{2}{|c|}{ Összes } \\
\hline & darab & $\begin{array}{l}\text { Szá- } \\
\text { zalék }\end{array}$ & darab & $\begin{array}{l}\text { szá- } \\
\text { zalék }\end{array}$ & darab & $\begin{array}{c}\text { szá- } \\
\text { zalék }\end{array}$ & darab & $\begin{array}{c}\text { szá- } \\
\text { zalék }\end{array}$ & darab & $\begin{array}{c}\text { Szá- } \\
\text { zalék }\end{array}$ \\
\hline Foglalkoztatott & 143682 & 63,9 & 34023 & 15,1 & 19650 & 8,7 & 27526 & 12,2 & 224881 & 100 \\
\hline Munkanélküli & 19419 & 72,9 & 4315 & 16,2 & 1822 & 6,8 & 1100 & 4,1 & 26656 & 100 \\
\hline Nyugdíjas & 191208 & 69,6 & 46453 & 16,9 & 20260 & 7,4 & 16972 & 6,2 & 274893 & 100 \\
\hline Anyasági ellátás & 2875 & 73,6 & 579 & 14,8 & 230 & 5,9 & 223 & 5,7 & 3907 & 100 \\
\hline Tanuló & 581 & 68,5 & 93 & 11,0 & 63 & 7,4 & 111 & 13,1 & 848 & 100 \\
\hline Egyéb & 18433 & 50,6 & 5138 & 14,1 & 3884 & 10,7 & 8989 & 24,7 & 36444 & 100 \\
\hline Összes & 376198 & 66,3 & 90601 & 16,0 & 45909 & 8,1 & 54921 & 9,7 & 567629 & 100 \\
\hline
\end{tabular}

Forrás: ÁMÖ 2010 alapján AKI Vidékfejlesztési Kutatási Osztály

A vizsgálat tárgyát képező 4000 euró STÉ alatti kisüzemek körében 2010-ben közel 180 ezer olyan gazdaság szerepelt, amelynek vezetője foglalkoztatottként végezte a mezőgazdasági tevékenységet. Ez a munkaerő-kapacitás lekötöttsége miatt az érintett gazdaságok továbbfejlesztésének korlátját jelentheti, ugyanakkor ezekben a háztartásokban nagyobb eséllyel képződnek a gazdaság fejlesztésére fordítható többletjövedelmek. További, komplex eszközrendszerrel fejlesztendő célcsoportot jelenthet az a közel 24 ezer kisgazdaság, amelynek vezetője munkanélküliként foglalkozott mezőgazdasági tevékenységgel. 


\section{Az egyéb jövedelemszerző tevékenységek szerepe}

A 2010-es összeírás szerint az egyéni gazdaságok közel 40 százaléka, mintegy 231,2 ezer üzem a mezőgazdasági tevékenység mellett egyéb, nem mezőgazdasági jövedelemszerző tevékenységet is végzett. Közülük mintegy 11,6 ezer gazdaság számára a tevékenység csak kiegészítő jövedelmet nyújtott, 219,5 ezer gazdaság esetében ugyanakkor jelentős bevételeket eredményezett. A nem mezőgazdasági tevékenységek gyakorlása a különböző STÉ-kategóriákba sorolt gazdaságokban közel azonos súllyal jelentkezett (25. táblázat).

25. táblázat: Kiegészítő tevékenységek szerepe STÉ-kategóriák szerint, 2010

\begin{tabular}{lrrrrrrrr}
\hline \multirow{2}{*}{ Megnevezés } & \multicolumn{2}{c}{ Nincs } & \multicolumn{2}{c}{ Kiegészító jellegú } & \multicolumn{2}{c}{ Jelentós } & \multicolumn{2}{c}{ Összes } \\
\cline { 2 - 9 } & \multicolumn{1}{c}{ darab } & százalék & darab & százalék & darab & százalék & darab & százalék \\
\hline 2000 euró STÉ alatt & 221963 & 58,7 & 7234 & 1,9 & 148793 & 39,4 & 377990 & 100 \\
\hline 2000-4000 euró STÉ & 52507 & 60,2 & 1747 & 2,0 & 33022 & 37,8 & 87276 & 100 \\
\hline $4000-8000$ euró STÉ & 25734 & 57,5 & 1060 & 2,4 & 17990 & 40,2 & 44784 & 100 \\
\hline 8000 euró STÉ felett & 32672 & 60,5 & 1627 & 3,0 & 19733 & 36,5 & 54032 & 100 \\
\hline Összes & 332876 & 59,0 & 11668 & 2,1 & 219538 & 38,9 & 564082 & 100 \\
\hline
\end{tabular}

Forrás: ÁMÖ 2010 alapján AKI Vidékfejlesztési Kutatási Osztály

A kiegészítő tevékenységek jövedelemtermelésben betöltött szerepéröl a gazdaságok termelési cél szerinti jellemzőinek áttekintése ad pontosabb képet (26. táblázat). A kiegészítő tevékenységek szerepe a piaci szerepvállalás mértékétől függ: míg a csak saját fogyasztásra termelő gazdaságvezetők 39,7 százaléka, a félig önellátó kör bő 40 százaléka, az árutermelők 44,7 százaléka, addig a mezőgazdasági szolgáltatók közel 60 százaléka folytatott kiegészítő tevékenységet 2010-ben (10. melléklet).

26. táblázat: Kiegészítő tevékenységek szerepe termelési cél szerint, 2010

\begin{tabular}{lrrrrrrrr}
\hline \multirow{2}{*}{ Megnevezés } & \multicolumn{2}{c}{ Nincs } & \multicolumn{2}{c}{ Kiegészító jellegú } & \multicolumn{2}{c}{ Jelentős } & \multicolumn{2}{c}{ Összes } \\
\cline { 2 - 9 } & darab & százalék & darab & százalék & darab & százalék & darab & százalék \\
\hline $\begin{array}{l}\text { Saját fogyasztásra } \\
\text { termelő }\end{array}$ & 204697 & 60,3 & 5833 & 1,7 & 129123 & 38,0 & 339653 & 100 \\
\hline Félig önellátó & 67329 & 58,9 & 2819 & 2,5 & 44212 & 38,7 & 114360 & 100 \\
\hline Értékesítésre termelő & 60772 & 55,3 & 3007 & 2,7 & 46108 & 42,0 & 109887 & 100 \\
\hline $\begin{array}{l}\text { Mezőgazdasági } \\
\text { szolgáltató }\end{array}$ & 78 & 42,9 & 9 & 4,9 & 95 & 52,2 & 182 & 100 \\
\hline Összes & 332876 & 59,0 & 11668 & 2,1 & 219538 & 38,9 & 564082 & 100 \\
\hline
\end{tabular}

Forrás: ÁMÖ 2010 alapján AKI Vidékfejlesztési Kutatási Osztály

A mezőgazdasági kistermelés hazai környezetben betöltött jelentőségének változásáról a népesség időfelhasználásának sajátosságait feltáró időmérleg-felvételek is támpontot adnak. Míg 2000-ben a 15-74 éves korosztály átlagosan 40 percet töltött el nem főállásúként mezőgazdasági munkával, és a tevékenység a népesség 23,5 százalékának napi rutinjához tartozott, addig 2010-re a tevékenységgel foglalkozók aránya 14,6 százalékra, a 15-74 éves népesség ezzel töltött átlagos ideje 20 percre csökkent, összefüggésben az idősebb, a kisléptékben végzett mezőgazdasági munkát még természetesnek tekintő generáció létszámának csökkenésével, valamint a dömpingáras élelmiszerek egyre könnyebb elérhetőségével (KSH, 2011b). 
Az egyéni gazdaságok szociodemográfiai szempontú vizsgálata során számos, a kisüzemeket a nagyobb árutermelő gazdaságoktól markánsan megkülönböztető jellemzőt azonosítottunk. A 4000 euró alatti STÉ-vel rendelkező gazdaságok vezetői körében az átlagnál jóval nagyobb az idősek és a fiatalok, a nyugdíjasok, munkanélküliek, képzetlenek, valamint a női üzemvezetők aránya. Ezzel szemben a 8000 euró STÉ feletti árutermelö gazdaságokat nagyobb valószínüséggel vezetik középkorúak, foglalkoztatottak, vállalkozók, magasabb képzettséggel rendelkezők, illetve férfiak. Az üzemvezetők és a gazdaságban dolgozók szociodemográfiai paramétereinek részletes vizsgálata arra is rámutatott, hogy a kisüzemek fejlesztése különösen a gazdálkodáshoz szükséges szakképzettségi szint növelését eredményező beavatkozásokat igényel. 


\section{A mezőgazdasági kisüzemek gazdálkodásának költség- jövedelem viszonyai a tesztüzemi rendszer alapján}

A fejezetben a tesztüzemi rendszerben 2013-ra rendelkezésre álló adatok alapján vizsgáljuk meg, milyen költség-jövedelem viszonyok jellemzik a hazai gazdatársadalom második legszélesebb, 2000-4000 euró STÉ közötti üzemmérettel rendelkező rétegét, majd összehasonlítjuk e réteg gazdálkodását az ennél nagyobb üzemmérettel rendelkező gazdaságokéval, végül jövedelmi szempontból is megvizsgáljuk, mit jelent a gazdálkodás ezen réteg számára. Az elemzés alapját adó 300 elemü tesztüzemi minta kialakításának módszertanát a 3. fejezetben mutattuk be részletesen.

\section{Költség-jövedelem szerkezet méretkategóriák szerinti alakulása}

Az Európai Bizottság üzemtipológiája alapján a 2000-4000 euró STÉ közötti méretkategória a 2-es méretnek felel meg. Ebbe a kategóriába jellemzően már 3,1 hektár búzával, 2,3 hektár kukoricával, 1,2 hektár szőlővel vagy gyümölcsössel, 1 tehénnel vagy 4 anyakocával be lehet kerülni. Ez az üzemméret a gyakorlati tapasztalat és a méreten alapuló definíció szerint viszont nem elegendő egy család, egy háztartás megélhetéséhez, ezért ezeknél az üzemeknél a mezőgazdasági tevékenység már csak mint kiegészítő tevékenység szerepel. Így itt a fó cél nem elsősorban az árutermelés, hanem a család saját szükségleteinek kielégítése, illetve a jövedelemkiegészítés.

A tesztüzemi rendszerben szereplő, 2000 és 4000 euró STÉ közötti 300 gazdaságban a hasznosított mezőgazdasági terület átlagosan 1,86 hektár. Ebből a legnagyobb részarányt a szántó teszi ki (1,44 hektár/üzem). A második legjelentősebb müvelési ág a legelő, átlagosan 0,33 hektár gazdaságonként, míg a szőlő és gyümölcsös területe mindösszesen 0,09 hektár/üzem. Az állatállományt tekintve egyegy gazdaság 0,89 számosállatot tart. Ezen belül legjelentősebb a sertéshizlalás $(0,28$ számosállat/ üzem), a juh- (0,25 számosállat/üzem), valamint a baromfitartás ( 0,20 számosállat/üzem).

Amennyiben a tesztüzemi rendszer 4000 euró STÉ méretküszöb alatti gazdaságainak (2-es méret) adatait a küszöb feletti méretkategóriákkal összevetjük, megállapítható, hogy a 3-as méretkategóriába tartozó, küszöb feletti gazdaságok több mint 3,7-szer nagyobb (6,83 hektár) területet müvelnek a küszöb alatti gazdaságokhoz képest (1,86 hektár). A 8000 euró STÉ méretküszöb feletti gazdaságok esetében a mezőgazdasági terület már átlagosan harminchatszorosa (66,91 hektár) a 2-es kategóriába tartozó gazdaságokénak (27. táblázat).

Ezzel szemben a mezőgazdaságra fordított munka tekintetében a 2-es méretű gazdaságok csak 32 százalékkal maradnak el a 3-as méretüekhez képest, ami azt eredményezi, hogy 1 hektárra közel 3-szor annyi a munkaerő-ráfordításuk. A 8000 euró STÉ feletti gazdaságokhoz képest már 6-szor annyi élő munkát használnak fel a 2-es méretkategóriába tartozó üzemek. Ez egyfelől azzal magyarázható, hogy munkaigényesebb tevékenységekkel foglalkoznak, másfelöl többlet kézi munkával pótolják a hiányzó eszközöket.

Az állatállományt vizsgálva a méret alatti kisüzemek 2,6-szor nagyobb állománnyal rendelkeznek 1 hektárra vetítve a küszöb feletti, 3-as méretkategóriába tartozó kisgazdaságoknál. Ez egyben azt is jelenti, hogy jelentősen magasabb az állatsűrűségük a küszöb feletti üzemekhez képest. Még a nagy árutermelő gazdaságokhoz képest is 60 százalékkal több állatot tartanak egységnyi területre vetítve.

A tesztüzemi gazdaságok adataiból egyértelműen kimutatható, hogy a mérethatékonyság miatt az állattartás a kisgazdaságokban kevésbé gazdaságos (Keszthelyi és Molnár, 2014), sőt gyakran veszteséges. Így a küszöb alatti kisgazdaságok esetében a nagyobb állatsürüség vélhetően a család saját ellátását szolgálja. 
Ha a 27. táblázat adatait a 2010-es ÁMÖ adataival vetjük össze, jól látható, hogy az egyes méretkategóriákban érdemben nem változott a használt földterület nagysága, jellemzően felére csökkent az átlagos munkaerö-lekötés, és minden méretkategóriában csökkent az állattartás mértéke.

\section{7. táblázat: A különböző méretkategóriájú üzemek főbb mutatói}

\begin{tabular}{|c|c|c|c|c|}
\hline Megnevezés & Mértékegység & $\begin{array}{l}\text { 2-es méret } \\
2000-4000 \\
\text { euró STÉ }\end{array}$ & $\begin{array}{l}\text { 3-as méret } \\
4000-8000 \\
\text { euró STÉ }\end{array}$ & $\begin{array}{l}\text { 4-es méret } \\
8000 \text { euró } \\
\text { STÉ felett }\end{array}$ \\
\hline Mezőgazdasági terület & hektár/üzem & 1,86 & 6,83 & 66,91 \\
\hline Átlagos munkaerő-lekötés & ÉME/üzem & 0,35 & 0,51 & 2,14 \\
\hline Munkaerő-állomány & ÉME/hektár & 0,19 & 0,07 & 0,03 \\
\hline Állatlétszám/munkaerö-lekötés & számosállat/ÉME & 2,56 & 2,44 & 8,93 \\
\hline Állatlétszám/földterület & $\begin{array}{l}\text { számosállat/ } \\
\text { hektár MT }\end{array}$ & 0,48 & 0,18 & 0,29 \\
\hline Eszközérték összesen & $\begin{array}{l}\text { ezer forint/ } \\
\text { hektár MT }\end{array}$ & 1873,06 & 1383,83 & 1080,82 \\
\hline Bruttó beruházás & $\begin{array}{l}\text { ezer forint/ } \\
\text { hektár MT }\end{array}$ & 59,30 & 35,78 & 100,85 \\
\hline Értékesítés nettó árbevétele & $\begin{array}{l}\text { ezer forint/ } \\
\text { hektár MT }\end{array}$ & 555,35 & 307,19 & 454,34 \\
\hline Bruttó termelési érték a mezőgazdaságban & $\begin{array}{l}\text { ezer forint/ } \\
\text { hektár MT }\end{array}$ & 694,27 & 444,89 & 604,91 \\
\hline Bruttó termelési érték a mezőgazdaságban & ezer forint/ÉME & 3730,44 & 6000,44 & 18931,97 \\
\hline Anyagköltség & $\begin{array}{l}\text { ezer forint/ } \\
\text { hektár MT }\end{array}$ & 399,55 & 223,82 & 362,49 \\
\hline Üzemi költségek a mezőgazdaságban & $\begin{array}{l}\text { ezer forint/ } \\
\text { hektár MT }\end{array}$ & 613,94 & 351,05 & 489,87 \\
\hline Adózás előtti eredmény & $\begin{array}{l}\text { ezer forint/ } \\
\text { hektár MT }\end{array}$ & 80,11 & 93,60 & 112,19 \\
\hline Adózás előtti eredmény & ezer forint/ÉME & 430,44 & 1262,42 & 3511,10 \\
\hline Termelésiérték-arányos jövedelmezőség & százalék & 11,54 & 21,04 & 18,55 \\
\hline
\end{tabular}

Megjegyzés: MT - Mezőgazdasági terület.

Forrás: Tesztüzemi adatok alapján az AKI Tesztüzemi Információs Osztálya

A 3,7-szer kisebb vetítési alap (MT) és a nagyobb értéket képviselő nagyobb állatsürüség miatt a küszöb alatti kisgazdaságok 1 hektárra vetítve nagyobb értékesítési árbevételt és bruttó termelési értéket értek el a küszöb feletti (4000-8000 euró STÉ) gazdaságokhoz képest. Viszont a felhasznált összes költségük arányaiban még ennél is magasabb, közel kétszerese a küszöb feletti kisgazdaságokénak. A kisebb méretből adódó alacsonyabb költséghatékonyság a vizsgált kisgazdaságoknál is érvényesül. Így összességében a két egymás melletti méretcsoport jövedelmezősége az adózás előtti eredmény tekintetében 17 százalékkal tér el: 80, illetve 94 ezer forint/hektár. A rosszabb munkaeröhatékonyság miatt az éves munkaerőegységre (ÉME) vetített eredmény pedig már harmada a küszöb feletti kisgazdaságok eredményének. 
A termelésiérték-arányos jövedelmezőség tekintetében a 2-es és 3-as méretkategóriában a differencia 1,8-szoros. Ez alapján megállapítható, hogy a kis méretből következő alacsony mérethatékonyság, valamint a mérsékelt munkaerő-kihasználtság miatt a vizsgált méretkategóriákban magas költséggel tudnak csak termelni, ami minden tekintetben rontja a mezőgazdasági tevékenység eredményességét.

Vannak bizonyos elemek, amelyek a 2-es, 3-as és 4-es csoport egybetartozását és az 5-ös csoporttól való elkülönülését mutatják (pl. az eszközérték nagysága, a bruttó beruházás mértéke, a számosállatra jutó munkaerőegység aránya), amelyek jól jelzik, hogy itt nagyobb termelési értéket állítanak elö, intenzívebb a gazdálkodás, az állattenyésztés pedig igen nagymértékủ munkaerő-felhasználás mellett folyik. Ezzel szemben azonban számosabbak azon érvek, amelyek a 4000 euró STÉ és az afeletti kategóriák elkülönítése irányába mutatnak.

Ilyen értékek a hektárra vetített munkaerő-állomány, az állatállomány alacsony mértéke a 3-as, 4-es kategóriában, a bruttó termelési érték és az értékesítés alacsonyabb szintje, a magasabb munkaerő-hatékonyság, az alacsonyabb anyag- és üzemi költségek, valamint a termelésiérték-arányos jövedelmezőség magasabb értéke.

Ez alapján elmondható, hogy a 3-as kategória esetében jellemzően még éppen nem fóállásban, de már meghatározó módon a mezőgazdasági termelés a gazdálkodó jövedelmének egyik alapja, amelyet alapvetően profitszerzési céllal végez, ennek megfelelően alacsonyan tartja az állattenyésztés szintjét, amely ha van, magas munkaerő-lekötést, tehát kevésbé hatékony termelést jelent. Mivel nem teljes föállásban kerül végzésre, ezért még viszonylag extenzív módon történik a gazdálkodás, alacsony ráfordításokkal, de már jó munkaerő-hatékonysággal.

Ehhez képest a nagyobb üzemek még nagyobb munkaerő-hatékonysággal, jóval nagyobb területen gazdálkodnak, több állatot tartva, magas hatékonysággal, minimális emberi erőforrás alkalmazásával, hektáronként magasabb ráfordításokat és magasabb termelési értéket elérve. A 2-es méretkategóriába eső kisüzemek ehhez képest több állatot tartanak, magasabb eszközlekötéssel, magas munkaerölekötéssel, magasabb termelési értékkel és ráfordításokkal, viszont jóval kisebb munkaerő-, tőke- és költséghatékonysággal, illetve profitrátával. Ennek oka az lehet, hogy ezen üzemek nem a profitot, hanem a bruttó jövedelmet, a profit és a munkajövedelem összegét maximalizálják, emellett a gyenge jövedelmezőség ellenére is fennálló magas állattartási kedv alapján termelési motivációként inkább az önellátás biztosítása a fő prioritásuk a jövedelmezőséggel szemben.

\section{A mezőgazdasági tevékenység súlya a jövedelemszerkezetben üzemtípusonként}

A vizsgált kisgazdaságok túlnyomó többségében a megtermelt javak a vidéki háztartások jövedelmét, a család saját fogyasztását egészítik ki. A 28. táblázat mutatja a vizsgált vidéki háztartások jövedelemszerkezetét annak függvényében, hogy milyen üzemtípusba sorolhatók.

Egy háztartásban átlagosan 2,5 fó élt, a teljes nettó jövedelmük 1853 ezer forint volt. Azoknál a háztartásoknál, ahol a növénytermesztés meghatározó, a jövedelem 28 százalékkal magasabb (2372 ezer forint), az állattartóknál és vegyes gazdaságoknál alacsonyabb (1729, illetve 1442 ezer forint). A 29. táblázatból jól látható, hogy az egyes üzemtípusok között nincsen érdemi különbség a jövedelemforrások nagysága esetében (eltekintve a vegyes gazdálkodást folytató üzemek 2013. évi veszteségességétől). 
28. táblázat: A 2. méretkategóriájú üzemekhez tartozó vidéki háztartások jövedelemszerkezete üzemtípusonként

\begin{tabular}{|c|c|c|c|c|c|}
\hline Megnevezés & Mértékegység & Összesen & $\begin{array}{c}\text { Növény- } \\
\text { termesztők }\end{array}$ & $\begin{array}{c}\text { Állat- } \\
\text { tenyésztők }\end{array}$ & $\begin{array}{c}\text { Vegyes } \\
\text { gazdaságok }\end{array}$ \\
\hline $\begin{array}{l}\text { Család (az egy háztartásban élök) } \\
\text { létszáma }\end{array}$ & fö/üzem & 2,50 & 2,65 & 2,55 & 2,48 \\
\hline $\begin{array}{l}\text { ebből: } 18-62 \text { év közötti } \\
\text { személyek létszáma }\end{array}$ & fö/üzem & 1,69 & 1,83 & 1,75 & 1,66 \\
\hline Kibocsátás ${ }^{\text {a) }}$ & ezer forint/üzem & 1142,36 & 1209,49 & 1221,03 & 969,21 \\
\hline $\begin{array}{l}\text { Mezőgazdasági üzem adózott } \\
\text { eredménye }\end{array}$ & ezer forint/üzem & 148,42 & 321,30 & 234,71 & $-139,90$ \\
\hline Önfoglalkoztatás jövedelme & ezer forint/üzem & 91,78 & 96,61 & 89,60 & 33,87 \\
\hline $\begin{array}{l}\text { Ingatlan- és tőkehasznosításból } \\
\text { származó jövedelem }\end{array}$ & ezer forint/üzem & 15,74 & 71,61 & 4,79 & 1,26 \\
\hline $\begin{array}{l}\text { Mezőgazdasági alkalmazotti } \\
\text { munkából származó jövedelem }\end{array}$ & ezer forint/üzem & 125,60 & 223,16 & 130,35 & 216,79 \\
\hline $\begin{array}{l}\text { Mezőgazdaságon kívüli } \\
\text { alkalmazotti munkából származó } \\
\text { jövedelem }\end{array}$ & ezer forint/üzem & 936,72 & 931,58 & 703,08 & 971,04 \\
\hline Nyugdíj & ezer forint/üzem & 428,04 & 563,92 & 464,49 & 239,00 \\
\hline Szociális juttatások & ezer forint/üzem & 58,84 & 105,06 & 65,82 & 104,51 \\
\hline Egyéb jövedelem & ezer forint/üzem & 47,87 & 58,93 & 35,71 & 15,75 \\
\hline Összes nettó jövedelem & ezer forint/üzem & 1853,02 & 2372,18 & 1728,56 & 1442,32 \\
\hline Élelmiszerre költött összeg (bruttó) & ezer forint/üzem & 516,29 & 646,25 & 484,22 & 587,40 \\
\hline
\end{tabular}

a) Támogatások nélkül számított termelési érték.

Forrás: Tesztüzemi adatok alapján az AKI Vállalkozáselemzési Osztálya

29. táblázat: A 2. méretkategóriájú üzemekhez tartozó vidéki háztartások nettó jövedelmének megoszlása üzemtípusonként

százalék

\begin{tabular}{lcccc}
\hline \multicolumn{1}{c}{ Megnevezés } & Összesen & $\begin{array}{c}\text { Növény- } \\
\text { termesztók }\end{array}$ & $\begin{array}{c}\text { Állat- } \\
\text { tenyésztők }\end{array}$ & $\begin{array}{c}\text { Vegyes } \\
\text { gazdaságok }\end{array}$ \\
\hline Adózott eredmény & 8,01 & 13,54 & 13,58 & $-9,70$ \\
\hline Önfoglalkoztatás jövedelme & 4,95 & 4,07 & 5,18 & 2,35 \\
\hline $\begin{array}{l}\text { Ingatlan- és tőkehasznosításból származó } \\
\text { jövedelem }\end{array}$ & 0,85 & 3,02 & 0,28 & 0,09 \\
\hline $\begin{array}{l}\text { Mezőgazdasági alkalmazotti munkából } \\
\text { származó jövedelem }\end{array}$ & 6,78 & 9,41 & 7,54 & 15,03 \\
\hline $\begin{array}{l}\text { Mezőgazdaságon kívüli alkalmazotti } \\
\text { munkából származó jövedelem }\end{array}$ & 50,55 & 39,27 & 40,67 & 67,33 \\
\hline Nyugdíj & 23,10 & 23,77 & 26,87 & 16,57 \\
\hline Szociális juttatások & 3,18 & 4,43 & 3,81 & 7,25 \\
\hline Egyéb jövedelem & 2,58 & 2,48 & 2,07 & 1,09 \\
\hline $\begin{array}{l}\text { Élelmiszerre költött összeg (bruttó) } \\
\text { és a nettó jövedelem aránya }\end{array}$ & 27,86 & 27,24 & 28,01 & 40,73 \\
\hline
\end{tabular}

Forrás: Tesztüzemi adatok alapján az AKI Vállalkozáselemzési Osztálya 
A jövedelem fele mezőgazdaságon kívüli alkalmazotti munkából származott, azaz ez a legfontosabb megélhetési forrásuk. A második legfontosabb jövedelemforrás a nyugdíj, ez az összes jövedelem negyedét teszi ki. Jelentős részt képvisel még a mezőgazdasági alkalmazotti munkából származó jövedelem (6,8 százalék), illetve az önfoglalkoztatás jövedelme (5 százalék). Annak ellenére, hogy a vizsgált háztartások az élelmiszer egy részét megtermelik, jövedelmük jelentős részét is erre költik.

Összességében a fenti számok alapján elmondható, hogy a mezőgazdasági tevékenység viszonylag kis szerepet játszik a mezőgazdasági termelést folytató háztartások életében, a jövedelemnek csupán 10 százalékát adja, ezzel az élelmiszer-fogyasztás kb. harmadát képes előteremteni. Mindezt úgy, hogy a kibocsátás több mint egymillió forintra rúg üzemenként, a jövedelem viszont csupán egyszázezer-kétszázezer forintra.

\section{A kisárutermelői kör mezőgazdasági tevékenységének értékelése az egyéb jövedelemszerző tevékenység alapján}

A tesztüzemi adatok vizsgálata kimutatta, hogy a mezőgazdasági kisüzemek jövedelemstruktúrájukat tekintve nem különböznek egymástól, amennyiben üzemtípusonként csoportosítjuk őket. Azonban a föbb egyéb jövedelemforrások nagyságrendje alapján feltehető a kérdés, hogy amennyiben az ilyen üzemek csak kiegészítő tevékenységet jelentenek, nem az nyomja-e inkább rá a bélyegét a gazdálkodásra, hogy a gazdaságvezető fóállásban milyen tevékenységet végez, mintsem az, hogy éppen milyen üzemtípusba sorolható az adott gazdaság. Ennek megfelelően a föbb jövedelemtípusok alapján soroltuk be a kisárutermelőket, és részletesen megvizsgáltuk gazdálkodásuk körülményeit.

Ez alapján öt csoport vált elkülöníthetővé: a főképpen vállalkozói jövedelmekből élő termelő, a mezőgazdasági, illetve a nem mezőgazdasági alkalmazott, a nyugdíjas, valamint a szociális juttatásból élő termelők csoportja. Látható a 30. táblázatból, hogy a legjellemzőbb ezek közül a nyugdíjas és a nem mezőgazdasági alkalmazott, míg a másik három kategória jóval ritkább Magyarországon.

Az öt csoport üzemtípusbeli besorolás alapján is jelentős mértékben eltérően viselkedik: míg a vállalkozók túlnyomórészt állattartással foglalkoznak, addig a mezőgazdasági alkalmazottak és a szociális juttatásokból élők vegyes gazdaságot müködtetnek, míg a nem mezőgazdasági alkalmazottak közel arányosan sorolhatók mindhárom típusba, a nyugdíjasok pedig jellemzően vagy állattenyésztéssel vagy növénytermesztéssel foglalkoznak.

Az üzemvezető átlagéletkora a gazdaságilag aktívak körében 40 év körüli, a nyugdíjasok átlagéletkora közel 70 év, míg a szociális juttatásból élők a maguk 55 éves korával az idősebb generációhoz tartoznak. Ennek megfelelően alakulnak a háztartások létszámai: az idősebb generációk (nyugdíjasok és szociális juttatásból élők) 2 körüli, a fiatalabb üzemvezetők 2,3-2,9 körüli átlagos létszámmal rendelkező családokban élnek.

A képzettség szempontjából az alkalmazottak vannak a legjobb helyzetben: mind a mezőgazdasági, mind a nem mezőgazdasági alkalmazottak esetében 14 százalék körüli a felsőfokú képzettséggel rendelkezők és 3-9 százalék között van az alapfokú végzettséggel rendelkezők aránya, a többiek pedig középfokú végzettséggel rendelkeznek. A vállalkozók esetében hiányzik a felsőfokú képzettség, a középfokú képzettséggel rendelkezők aránya azonban 90 százalék felett van. A nyugdíjasok esetében 25 , a szociális juttatásból élők között 18 százalék az alapfokú végzettségüek aránya, míg a felsőfokú képzéssel rendelkezők aránya 7, illetve 5 százalék, ami jelzi, hogy még a diploma sem véd meg feltétlenül a munkaerőpiacról való kieséstől. 
30. táblázat: Fontosabb üzemmutatók a meghatározó egyéb jövedelemtípusok szerinti bontásban

\begin{tabular}{|c|c|c|c|c|c|c|}
\hline Megnevezés & $\begin{array}{l}\text { Mérték- } \\
\text { egység }\end{array}$ & $\begin{array}{c}\text { Önfoglal- } \\
\text { koztató } \\
\text { (vállalkozó) }\end{array}$ & $\begin{array}{c}\text { Mezőgaz- } \\
\text { dasági } \\
\text { alkalmazott }\end{array}$ & $\begin{array}{c}\text { Mezőgaz- } \\
\text { daságon } \\
\text { kívüli } \\
\text { alkalmazott } \\
\end{array}$ & Nyugdíjas & $\begin{array}{c}\text { Szociális } \\
\text { juttatásból } \\
\text { élő }\end{array}$ \\
\hline $\begin{array}{l}\text { Üzemszám } \\
\text { az alapsokaságban }\end{array}$ & darab & 4144 & 4745 & 34567 & 24198 & 2471 \\
\hline ebböl növénytermesztők & százalék & 15,03 & 25,31 & 25,03 & 36,82 & 25,66 \\
\hline állattartók & százalék & 74,83 & 11,62 & 39,22 & 47,70 & 9,53 \\
\hline vegyes gazdaságok & százalék & 10,14 & 63,07 & 35,74 & 15,48 & 64,81 \\
\hline Háztartás átlaglétszáma & fö/üzem & 2,80 & 2,32 & 2,89 & 2,02 & 2,11 \\
\hline Üzemvezető átlagéletkora & év & 41,86 & 40,30 & 44,95 & 67,44 & 55,88 \\
\hline \multicolumn{7}{|l|}{ Üzemvezetők végzettsége } \\
\hline alapfokú & százalék & 7,35 & 2,54 & 8,60 & 24,64 & 18,27 \\
\hline középfokú & százalék & 92,65 & 83,84 & 76,57 & 68,29 & 76,85 \\
\hline felsőfokú & százalék & 0,00 & 13,61 & 14,83 & 7,08 & 4,88 \\
\hline Mezőgazdasági terület & hektár/üzem & 1,35 & 2,00 & 1,66 & 2,05 & 2,18 \\
\hline $\begin{array}{l}\text { Átlagos } \\
\text { munkaerő-lekötés }\end{array}$ & ÉME/üzem & 0,29 & 0,41 & 0,29 & 0,37 & 0,37 \\
\hline Állatlétszám/földterület & $\begin{array}{l}\text { számosállat/ } \\
\text { hektár }\end{array}$ & 0,37 & 0,73 & 0,50 & 0,42 & 0,67 \\
\hline Eszközérték összesen & $\begin{array}{l}\text { ezer forint/ } \\
\text { hektár }\end{array}$ & 4085,79 & 2466,53 & 1828,76 & 1716,35 & 1077,16 \\
\hline $\begin{array}{l}\text { Eszközérték a föld } \\
\text { és az állatok értéke nélkül }\end{array}$ & $\begin{array}{l}\text { ezer forint/ } \\
\text { hektár }\end{array}$ & 3365,97 & 1529,72 & 1027,91 & 964,08 & 173,92 \\
\hline Bruttó beruházás & $\begin{array}{l}\text { ezer forint/ } \\
\text { hektár }\end{array}$ & 2,68 & 183,52 & 85,97 & 25,04 & 19,11 \\
\hline $\begin{array}{l}\text { Bruttó termelési érték } \\
\text { a mezőgazdaságban }\end{array}$ & $\begin{array}{l}\text { ezer forint/ } \\
\text { hektár }\end{array}$ & 1204,09 & 574,68 & 736,65 & 643,60 & 495,79 \\
\hline
\end{tabular}

Forrás: Tesztüzemi adatok alapján az AKI Vállalkozáselemzési Osztálya

Az öt csoport közül a vállalkozók és a nem mezőgazdasági alkalmazottak rendelkeznek a legkisebb földterülettel (1,35, illetve 1,66 hektár), a többi csoportban pedig átlagosan 2 hektáron gazdálkodnak. A háztartások munkaerö-lekötése nagyjából egyharmadnyi föállású foglalkoztatott munkaidejének felel meg, ez a mezőgazdasági alkalmazottaknál, a nyugdíjasoknál és a szociális jövedelemből élőknél kicsit magasabb, a másik két csoportban kissé alacsonyabb.

Az állatállomány a mezőgazdasági alkalmazottaknál és a szociális jövedelemből élőknél a legmagasabb, míg a vállalkozóknál a legalacsonyabb (miközben ők sorolhatók be legtöbben az állattartók közé, tehát ebben az esetben nagy értékü állatitermék-eladás történhet).

A legnagyobb relatív eszközértékkel a vállalkozók gazdálkodnak. Ez a kör jellemzően vállalkozó szemléletü, kockázatot és beruházást is nagyobb arányban vállal. Öket a mezőgazdasági alkalmazottak követik. Ezzel szemben a szociális juttatásban részesülök eszközértéke a legalacsonyabb, de még itt is hektáronként 1 millió forintos eszközértékről beszélhetünk, ami igen jelentős összegnek tünik. Ha azonban ebböl levonjuk a föld és az állatállomány becsült értékét, világosan megmutatkozik, hogy míg a vállalkozók igen jelentős eszközökkel rendelkeznek, és az alkalmazottak, valamint a nyugdíjasok eszközvagyona is hektáronként 1 millió forint körüli, addig a szociális juttatásból élők gyakorlatilag érdemi eszközök nélkül (valószínüleg csak kéziszerszámokkal) gazdálkodnak. 
A gazdálkodásban megjelenő fenti különbségeket az egy hektárra jutó bruttó termelési érték is alátámasztja. Az önfoglalkoztató gazdálkodók termelési értéke (1204 ezer forint/hektár) több mint kétszer magasabb, mint akik mezőgazdasági tevékenység mellett elsősorban szociális juttatásokból tartják fenn magukat (495 ezer forint/hektár).

Ha az öt gazdálkodói csoport bevételét vizsgáljuk, látható, hogy a leginkább specializált termelést és értékesítést a vállalkozók végzik, náluk az alapvető szántóföldi termesztés mellett szinte kizárólag az állattenyésztésből származik értékesíthető termék, amely azonban több mint kétszeresével haladja meg az alkalmazottak és nyugdíjasok értékesítését és négyszeresen a szociális jövedelemből élőkét. Emellett a mezőgazdasági alkalmazottak és a szociális jövedelemböl élők rendelkeznek hasonló értékesítési struktúrával (minimális gyümölcsértékesítéssel kiegészítve a bevételeket), míg a nem mezőgazdasági alkalmazottak, nyugdíjasok az állati termékek értékesítése mellett kertészkedéssel, szőlőmüveléssel, gyümölcstermesztéssel és -értékesítéssel is foglalkoznak.

Fontos felhívni a figyelmet arra, hogy az értékesítés nettó árbevételébe a tesztüzemi rendszer beleszámolja a család saját fogyasztását is, e nélkül jól láthatóan 25 százalékkal csökken a szociális juttatásból élők értékesítése, viszont a többi gazdaság esetében ez a tétel elhanyagolhatóan kicsi. Megjegyzendő azonban, hogy ezekben az esetekben nem feltétlenül tényleges értékesítésről van szó, ami pénzmozgással jár, hanem minden olyan esetről, amikor árucsere folyik, tehát pénzmozgás nélküli, a háztartás számára viszontszolgáltatást jelentő áruátadás történik (pl. komatálat adok a disznóvágásból). Ezzel a kiegészítéssel már életszerübbnek tünik, hogy ilyen kisgazdaságok esetén is a termelési érték ilyen nagy része (75-95 százaléka) kerül értékesítésre.

Az egyéb bevételek között három fontos tétel található: a támogatások, a földbérleti díj, valamint az értékesített tárgyi eszközök. Ez utóbbi főként a nyugdíjasoknál és a szociális juttatásból élőknél jelentős, de ott sem túlzottan, míg a vállalkozóknál gyakorlatilag nem történik ilyen értékesítés. A földbérleti díj súlya is minimális, ami jól jelzi, hogy érdemben egyik gazdálkodói csoport sem képes további földterületet bevonni a gazdálkodásba (31. táblázat).

A legnagyobb tételt a vissza nem térítendő támogatások sor adja, amely nagyságrendjét tekintve az alkalmazottaknál, nyugdíjasoknál és a szociális juttatásból élőknél a területalapú támogatással egyenlő. Ennek az összegnek több mint kétszeresét kapják a vállalkozók, ami jelzi, hogy ez a csoport rendelkezik olyan képességekkel, amelyek lehetővé teszik az egyéb támogatásokhoz való hozzáférést.

Megvizsgálva a bruttó termelési érték és a munkaidő-ráfordítások kapcsolatát, jól látható, hogy a vállalkozók végzik leghatékonyabban a munkájukat, majd a mezőgazdaságon kívüli alkalmazottak következnek, a sort pedig a nyugdíjasok, szociális juttatásból élők és mezőgazdasági alkalmazottak zárják. 
31. táblázat: Bevételek alakulása a meghatározó egyéb jövedelemtípusok szerinti bontásban

\begin{tabular}{|c|c|c|c|c|c|c|}
\hline Megnevezés & $\begin{array}{l}\text { Mérték- } \\
\text { egység }\end{array}$ & $\begin{array}{c}\text { Önfoglal- } \\
\text { koztató } \\
\text { (vállalkozó) }\end{array}$ & $\begin{array}{l}\text { Mezőgaz- } \\
\text { dasági } \\
\text { alkalmazott }\end{array}$ & $\begin{array}{l}\text { Mezőgaz- } \\
\text { daságon } \\
\text { kívüli } \\
\text { alkalmazott } \\
\end{array}$ & Nyugdíjas & $\begin{array}{c}\text { Szociális } \\
\text { juttatásból } \\
\text { élő }\end{array}$ \\
\hline $\begin{array}{l}\text { Értékesítés } \\
\text { nettó árbevétele összesen }\end{array}$ & $\begin{array}{l}\text { ezer forint/ } \\
\text { hektár }\end{array}$ & 908,02 & 461,73 & 601,80 & 503,55 & 408,95 \\
\hline $\begin{array}{l}\text { Szántóföldi } \\
\text { növénytermesztés, } \\
\text { gyepgazdálkodás }\end{array}$ & $\begin{array}{l}\text { ezer forint/ } \\
\text { hektár }\end{array}$ & 83,76 & 103,76 & 112,92 & 98,86 & 88,36 \\
\hline Állattenyésztés & $\begin{array}{l}\text { ezer forint/ } \\
\text { hektár }\end{array}$ & 799,68 & 303,58 & 350,36 & 270,06 & 195,15 \\
\hline Kertészeti termelés & $\begin{array}{l}\text { ezer forint/ } \\
\text { hektár }\end{array}$ & 4,29 & 0,00 & 23,88 & 38,25 & 0,00 \\
\hline Gyümölcstermesztés & $\begin{array}{l}\text { ezer forint/ } \\
\text { hektár }\end{array}$ & 0,00 & 2,52 & 30,01 & 38,85 & 11,10 \\
\hline Szőlö- és bortermelés & $\begin{array}{l}\text { ezer forint/ } \\
\text { hektár }\end{array}$ & 0,00 & 0,00 & 22,03 & 16,50 & 0,00 \\
\hline $\begin{array}{l}\text { A család saját } \\
\text { fogyasztása }\end{array}$ & $\begin{array}{l}\text { ezer forint/ } \\
\text { hektár }\end{array}$ & 20,28 & 43,01 & 52,59 & 37,93 & 114,34 \\
\hline $\begin{array}{l}\text { Értékesítés } \\
\text { nettó árbevétele } \\
\text { a család saját fogyasztása } \\
\text { nélkül }\end{array}$ & $\begin{array}{l}\text { ezer forint/ } \\
\text { hektár }\end{array}$ & 887,73 & 418,72 & 549,21 & 465,61 & 294,61 \\
\hline Egyéb bevételek összesen & $\begin{array}{l}\text { ezer forint/ } \\
\text { hektár }\end{array}$ & 210,03 & 105,48 & 105,37 & 129,39 & 95,94 \\
\hline $\begin{array}{l}\text { Értékesített immat. } \\
\text { javak, tárgyi eszközök } \\
\text { bevétele }\end{array}$ & $\begin{array}{l}\text { ezer forint/ } \\
\text { hektár }\end{array}$ & 0,70 & 6,46 & 6,12 & 21,70 & 15,13 \\
\hline $\begin{array}{l}\text { Visszafizetési kötelezett- } \\
\text { ség nélküli támogatások }\end{array}$ & $\begin{array}{l}\text { ezer forint/ } \\
\text { hektár }\end{array}$ & 201,36 & 73,60 & 70,53 & 79,77 & 67,49 \\
\hline $\begin{array}{l}\text { Földterület } \\
\text { bérbeadásából } \\
\text { származó bevételek }\end{array}$ & $\begin{array}{l}\text { ezer forint/ } \\
\text { hektár }\end{array}$ & 5,41 & 10,56 & 4,09 & 5,79 & 0,00 \\
\hline $\begin{array}{l}\text { Aktivált saját } \\
\text { teljesítmények értéke }\end{array}$ & $\begin{array}{l}\text { ezer forint/ } \\
\text { hektár }\end{array}$ & 86,04 & 7,47 & 29,48 & 10,66 & $-9,11$ \\
\hline $\begin{array}{l}\text { Bruttó termelési érték } \\
\text { a mezőgazdaságban }\end{array}$ & $\begin{array}{l}\text { ezer forint/ } \\
\text { hektár }\end{array}$ & 1204,09 & 574,68 & 736,65 & 643,60 & 495,79 \\
\hline $\begin{array}{l}\text { Bruttó termelési érték } \\
\text { a mezőgazdaságban }\end{array}$ & $\begin{array}{l}\text { ezer forint/ } \\
\text { ÉME }\end{array}$ & 5634,64 & 2830,31 & 4224,21 & 3574,39 & 2936,36 \\
\hline
\end{tabular}

Forrás: Tesztüzemi adatok alapján az AKI Vállalkozáselemzési Osztálya

Az öt csoport költségstruktúráját vizsgálva megállapítható, hogy a vállalkozók rendelkeznek a legnagyobb üzemi költségszinttel, amelyet a mezőgazdasági alkalmazottak, a nem mezőgazdasági alkalmazottak, a nyugdíjasok és a szociális juttatásból élők követnek - a szociális juttatásból élők szinte már csak feleannyit fordítanak termelésre, mint a vállalkozók (32. táblázat).

Az üzemi költségeken belül a legnagyobb szeletet az anyagjellegü ráfordítások adják, amelyen belül az állattenyésztés ráfordításai a legjelentősebbek - a vállalkozók közel háromszor annyi takarmányt, egyéb, közvetlenül az állattenyésztéshez kapcsolódó anyagot vesznek meg, mint a nyugdíjasok és a szociális juttatásból élők. A növénytermesztés, valamint az egyéb anyagköltségek esetében nincsenek ekkora különbségek, bár mindenhol vannak kiugró értékek. 
A személyi jellegü költségek két kiugró esete a mezőgazdasági alkalmazottaké - nyilván ezen réteg fér hozzá legkönnyebben a nagyobb mezőgazdasági vállalkozások szolgáltatásaihoz, a másik végletet a vállalkozók jelentik, akik személyi költségekre nem áldoznak pénzt - vélhetően megvannak a saját emberi erőforrásaik a gazdálkodás során felmerülő munkálatok elvégzéséhez.

Az értékcsökkenési leírás alkalmazkodik az eszközértékhez, így a vállalkozóknál a legnagyobb ez az érték. Az egyéb ráfordítások között pedig a család saját fogyasztása a legnagyobb tétel, amely biztosítja, hogy az üzem valós termelése is megjelenjen, még ha az adott termelés az üzemen (háztartáson) belül elfogyasztásra kerül is.

\section{2. táblázat: Költségek alakulása a meghatározó egyéb jövedelemtípusok szerinti bontásban}

ezer forint/hektár

\begin{tabular}{|c|c|c|c|c|c|}
\hline Megnevezés & $\begin{array}{c}\text { Önfoglal- } \\
\text { koztató } \\
\text { (vállalkozó) }\end{array}$ & $\begin{array}{l}\text { Mezőgaz- } \\
\text { dasági } \\
\text { alkalmazott }\end{array}$ & $\begin{array}{l}\text { Mezőgaz- } \\
\text { daságon } \\
\text { kívüli } \\
\text { alkalmazott }\end{array}$ & Nyugdíjas & $\begin{array}{c}\text { Szociális } \\
\text { juttatásból } \\
\text { élő }\end{array}$ \\
\hline Anyagjellegü ráfordítások & 560,85 & 462,38 & 429,33 & 354,44 & 251,73 \\
\hline $\begin{array}{l}\text { Növénytermesztés } \\
\text { kiemelt anyagköltségei }\end{array}$ & 30,87 & 31,88 & 61,64 & 56,54 & 31,43 \\
\hline $\begin{array}{l}\text { Állattenyésztés kiemelt } \\
\text { anyagköltségei }\end{array}$ & 393,10 & 270,04 & 176,85 & 146,91 & 123,40 \\
\hline $\begin{array}{l}\text { Egyéb anyagköltség a mezőgazdasági } \\
\text { tevékenységben }\end{array}$ & 75,22 & 74,52 & 97,16 & 67,37 & 39,09 \\
\hline Igénybe vett szolgáltatások költsége & 51,22 & 77,79 & 82,28 & 71,79 & 53,15 \\
\hline Egyéb szolgáltatások költsége & 10,44 & 8,15 & 11,40 & 8,64 & 4,65 \\
\hline Személyi jellegü ráfordítások összesen & 0,00 & 92,37 & 65,12 & 38,49 & 35,18 \\
\hline Értékcsökkenési leírás & 123,35 & 55,30 & 82,31 & 50,68 & 26,19 \\
\hline Egyéb ráfordítások összesen & 40,31 & 89,12 & 109,63 & 86,88 & 139,96 \\
\hline A család saját fogyasztása & 20,28 & 43,01 & 52,59 & 37,93 & 114,34 \\
\hline Üzemi költségek a mezőgazdaságban & 724,51 & 699,17 & 686,38 & 530,49 & 453,06 \\
\hline $\begin{array}{l}\text { Üzemi költségek a saját fogyasztás } \\
\text { nélkül }\end{array}$ & 704,23 & 656,16 & 633,79 & 492,56 & 338,71 \\
\hline $\begin{array}{l}\text { Üzemi költségek a saját fogyasztás } \\
\text { és értékcsökkenés (ÉCS) nélkül }\end{array}$ & 580,88 & 600,86 & 551,49 & 441,87 & 312,52 \\
\hline $\begin{array}{l}\text { Üzemi költségek a saját fogyasztás, az } \\
\text { ÉCS és a személyi ráfordítások nélkül }\end{array}$ & 580,88 & 508,49 & 486,37 & 403,39 & 277,35 \\
\hline
\end{tabular}

Forrás: Tesztüzemi adatok alapján az AKI Vállalkozáselemzési Osztálya

Annak érdekében, hogy a mezőgazdasági termelés valós értékét (mennyi élelmiszert képes biztosítani a családnak) meg tudjuk ítélni a háztartások szempontjából, el kell távolodnunk a számvitel szigorú logikájától. A tesztüzemi rendszer alapvető célja a jövedelem, a profit kimutatása, ezzel szemben a mezőgazdasági háztartások hasznossági szempontból nyilvánvalóan nem úgy különítik el jövedelmeiket, fogyasztásukat, hogy azok saját munkaerejük megőrzésére, eszközeik pótlására vagy más egyébre használatosak. A család saját fogyasztása sokkal inkább jövedelmi, mint költségkategória, ezért ezzel a tétellel csökkenteni lehet az üzemi költségeket.

Ugyanez a helyzet az értékcsökkenési leírással - e kategória beruházási mutatókkal történő összevetése jól jelzi, hogy ilyen kis üzemméret esetén nem folyamatos az eszközök pótlása, hanem lökésszerü: akár tíz évig is használnak egy eszközt, és csak utána cserélik le -, így történhet, hogy 
a legnagyobb eszközértékkel rendelkező vállalkozóknál nincs érdemi beruházás, a mezőgazdasági alkalmazottaknál viszont jóval meghaladja az értékcsökkenési leírást. Ennek megfelelően a napi müködést tekintetbe véve az értékcsökkenés összegével is csökkenteni lehet az üzemi költségek mértékét.

A vidéki társadalomban az egymásnak végzett munkák rendszere sokkal inkább szívességi alapon, kölcsönös segítségnyújtás keretében történik, mint érdemi fizetség ellenében. Ennek megfelelően jóval gyakoribb, hogy egy mezőgazdasági szolgáltatás elvégzésekor (pl. a kert megszántásakor) csak a gépköltség, az üzemanyag elszámolása történik meg, míg a személyi költség, a munkadíj nem kerül felszámításra, mivel egy későbbi viszontszívességgel ,egyenlítik ki” a számlát. Ebben az esetben a tesztüzemben megjelenik a munka valós költsége, viszont a mezőgazdasági háztartás számára nem jelent azonnali költséget ez a tétel. Különösen így lehet ez a mezőgazdasági nagyüzemben dolgozó termelők esetében, akik a cég gépén, a cég alkalmazottjaként akár saját maguk is végezhetik kisüzemük müvelését, miközben nyilvánvalóan nem fizetik ki saját pénzükből a maguknak elvégzett munka díját. Így indokolt legalább a felmerülő személyi költségek levonása az üzemi költségekből. Ebben az esetben az üzemi költségek sorrendje nem változik, de a ráfordítások nagyságrendje már igen - a vállalkozók már több mint kétszer akkora költséggel dolgoznak, mint a szociális juttatásból élők.

Ha a tesztüzemi rendszer szigorú számviteli logikája alapján értékeljük az üzemek teljesítményét, a következő megállapításra juthatunk: a mezőgazdasági alkalmazottak gazdálkodnak a a legkevésbé eredményesen, ők hektáronként több mint 100 ezer forintos veszteséget halmoznak fel. A nem mezőgazdasági alkalmazottak és a szociális juttatásból élők hektáronként 40-50 ezer forintos jövedelmet érnek el, míg a vállalkozók közel 500 ezer forintos, tehát tízszeres jövedelmet képesek kitermelni hektáronként. Ez termelésiérték-arányosan közel 40 százalékos teljesítmény, jóval meghaladja a 4000 euró STÉ feletti mezőgazdasági üzemek átlagát, és az eszközarányos jövedelmezőség is megfelelő, 10 százalék feletti - van értelme tehát a magas szintű eszközlekötésnek. A munkaerő jövedelmezősége is megfelelő - nettó 2,2 millió forintos jövedelmet hozna teljes állásban, ami jóval a vidéki átlagkeresetek felett található. Ezzel szemben a többi esetben rendkívül kevéssé hatékony munkával találkozunk - egyévnyi munkáért 250, de még 600 ezer forint is túl kevés jövedelemnek tünik, nem is beszélve a mezőgazdasági alkalmazottakról, akik számára a mezőgazdasági kisüzem igen drága passziónak bizonyul - egész éves munkájukért ilyen keretek között 600 ezer forintot kellene fizetniük.

Amennyiben a köznapi értelemben vett hasznosság fogalom használata mellett vizsgáljuk meg a jövedelemtermelő képességet, hozzáadva az eredményhez a család saját fogyasztását, az értékcsökkenést és a személyi ráfordításokat, már egyetlen esetben sem negatív az eredmény. A vállalkozók így már 600 ezer forintos eredményre tesznek szert, míg a legkisebb eredménnyel, hektáronként 60 ezer forinttal a mezőgazdasági alkalmazottak rendelkeznek. Amennyiben ezen tételt az igénybe vett szolgáltatások költségével is megnöveljük (feltételezve, hogy a mezőgazdasági alkalmazott cége ingyen végzi a gépi munkákat), úgy az összeg eléri a 152 ezer forintot. A többi kategóriába sorolt termelő hektáronként 220-250 ezer forintos jövedelmet ér el, ami már jelentős tételnek számít. Az összevetésből jól látható, hogy mindegyik csoport számára érdemi jövedelemtermelő tevékenységet jelent a mezőgazdaság, jóval magasabb hektáronkénti fogyasztási alapot teremtve, mint egy átlagos mezőgazdasági közép- vagy nagyüzem esetén (33. táblázat). 


\section{3. táblázat: Jövedelem és hatékonyság alakulása a meghatározó egyéb jövedelemtípusok szerinti bontásban}

\begin{tabular}{|c|c|c|c|c|c|c|}
\hline Megnevezés & $\begin{array}{l}\text { Mérték- } \\
\text { egység }\end{array}$ & $\begin{array}{l}\text { Önfoglal- } \\
\text { koztató } \\
\text { (vállalkozó) }\end{array}$ & $\begin{array}{l}\text { Mezőgaz- } \\
\text { dasági } \\
\text { alkalmazott }\end{array}$ & $\begin{array}{l}\text { Mezőgaz- } \\
\text { daságon } \\
\text { kívüli } \\
\text { alkalmazott }\end{array}$ & Nyugdíjas & $\begin{array}{c}\text { Szociális } \\
\text { juttatásból } \\
\text { élő }\end{array}$ \\
\hline $\begin{array}{l}\text { Adózás előtti eredmény } \\
\text { (a továbbiakban AEE) }\end{array}$ & $\begin{array}{l}\text { ezer forint/ } \\
\text { hektár }\end{array}$ & 479,58 & $-123,65$ & 50,01 & 112,64 & 42,69 \\
\hline $\begin{array}{l}\text { Termelésiérték-arányos } \\
\text { jövedelmezőség }\end{array}$ & százalék & 39,83 & $-21,52$ & 6,79 & 17,50 & 8,61 \\
\hline $\begin{array}{l}\text { Eszközarányos } \\
\text { jövedelmezőség }\end{array}$ & százalék & 11,74 & $-5,01$ & 2,73 & 6,56 & 3,96 \\
\hline $\begin{array}{l}\text { Munkaerö-arányos } \\
\text { jövedelmezőség }\end{array}$ & $\begin{array}{l}\text { ezer forint/ } \\
\text { ÉME }\end{array}$ & 2244,23 & $-609,00$ & 286,77 & 625,57 & 252,85 \\
\hline $\begin{array}{l}\text { AEE a saját fogyasztás } \\
\text { beszámításával }\end{array}$ & $\begin{array}{l}\text { ezer forint/ } \\
\text { hektár }\end{array}$ & 499,86 & $-81,48$ & 102,86 & 151,04 & 157,07 \\
\hline $\begin{array}{l}\text { AEE a saját fogyasztás } \\
\text { és az ÉCS beszámításával }\end{array}$ & $\begin{array}{l}\text { ezer forint/ } \\
\text { hektár }\end{array}$ & 623,21 & $-26,19$ & 185,16 & 201,72 & 183,26 \\
\hline $\begin{array}{l}\text { AEE a saját fogyasztás, } \\
\text { az ÉCS és a személyi } \\
\text { ráfordítások } \\
\text { beszámításával }\end{array}$ & $\begin{array}{l}\text { ezer forint/ } \\
\text { hektár }\end{array}$ & 623,21 & $\begin{array}{c}66,19 \\
(152,13)^{\mathrm{a})}\end{array}$ & 250,28 & 240,21 & 218,44 \\
\hline $\begin{array}{l}\text { Termelésiérték-arányos } \\
\text { jövedelmezőség }\end{array}$ & százalék & 51,76 & $\begin{array}{c}11,52 \\
(26,41)^{\mathrm{a})}\end{array}$ & 33,98 & 37,32 & 44,06 \\
\hline $\begin{array}{l}\text { Eszközarányos } \\
\text { jövedelmezőség }\end{array}$ & százalék & 15,25 & $\begin{array}{l}2,68 \\
(6,16)^{a)}\end{array}$ & 13,69 & 14,00 & 20,28 \\
\hline $\begin{array}{l}\text { Munkaerö-arányos } \\
\text { jövedelmezőség }\end{array}$ & $\begin{array}{l}\text { ezer forint/ } \\
\text { ÉME }\end{array}$ & 2916,35 & $\begin{array}{c}325,97 \\
(742,09)^{\mathrm{a})} \\
\end{array}$ & 1435,19 & 1334,07 & 1293,73 \\
\hline
\end{tabular}

a) Hozzáadva az igénybe vett szolgáltatások költségét.

Forrás: Tesztüzemi adatok alapján az AKI Vállalkozáselemzési Osztálya

Ezen eredményeket vizsgálva termelésiérték-arányosan igen magas, 30-50 százalékos értékeket kapunk, ahol a vállalkozók értéke a legmagasabb, de a szociális juttatásból élők is magas, 40 százalékos értékkel rendelkeznek - elsősorban az alacsony anyagjellegű költségek okán. Az eszközarányos jövedelmezőség is magasabb, 6-13-15 százalék, a legmagasabb értéket pedig a szociális juttatásból élők kapják, alacsonyabb eszközellátottságuk okán.

A munkaerő-arányos jövedelmezőségi mutatószámok szempontjából továbbra is a vállalkozók működtetik a leghatékonyabban üzemüket, a mezőgazdasági alkalmazottaknál a pontosabban becsült munkaidő-felhasználás miatt alacsonyabb ez a szám, míg a többi kategóriában közel azonos szintü, éves munkaerőegységre jutóan 1,3-1,4 millió forintos fogyasztási alap keletkezik, ami nagyságrendileg azonos munkaerő-hatékonyságot feltételez mindhárom esetben (34. táblázat).

Amennyiben megvizsgáljuk, hogy az üzemekben előállított fogyasztási alap milyen szerepet tölt be a háztartások életében, a következő megállapításokat tehetjük. A termelési érték a kisgazdaságokban 1-1,6 millió forintra rúg, ebből a felhasználható jövedelem értéke 800 ezer forint a vállalkozók esetében, 132 ezer (az igénybe vett szolgáltatásokat beleszámítva 304 ezer) forint a mezőgazdasági alkalmazottaknál és 400-500 ezer forint körüli szintet ér el az egyéb alkalmazottak, nyugdíjasok és szociális jövedelemböl élök körében (34. táblázat). 
Fontos megjegyezni, hogy a felhasználható jövedelem jelentős részét képezik a KAP-ból származó agrártámogatások, amelyek a minimális földbérleti díjakkal együtt a felhasználható jövedelemnek jellemzően 30 százalékát teszik ki (a mezőgazdasági alkalmazottaknál pedig akár az 50 százalékát is meghaladhatják), így érdemben járulnak hozzá a felhasználható jövedelem viszonylag magas szintjéhez.

\section{4. táblázat: A fogyasztásban betöltött szerep a meghatározó egyéb jövedelemtípusok szerinti bontásban}

\begin{tabular}{|c|c|c|c|c|c|c|}
\hline Megnevezés & $\begin{array}{l}\text { Mérték- } \\
\text { egység }\end{array}$ & $\begin{array}{c}\text { Önfoglal- } \\
\text { koztató } \\
\text { (vállalkozó) }\end{array}$ & $\begin{array}{l}\text { Mezőgaz- } \\
\text { dasági } \\
\text { alkalmazott }\end{array}$ & $\begin{array}{l}\text { Mezőgaz- } \\
\text { daságon } \\
\text { kívüli } \\
\text { alkalmazott }\end{array}$ & Nyugdíjas & $\begin{array}{l}\text { Szociális } \\
\text { juttatásból } \\
\text { élő }\end{array}$ \\
\hline Bruttó termelési érték & $\begin{array}{l}\text { ezer forint/ } \\
\text { üzem }\end{array}$ & 1620,81 & 1149,66 & 1224,62 & 1318,57 & 1082,55 \\
\hline $\begin{array}{l}\text { Támogatás } \\
\text { és földbérleti díj }\end{array}$ & $\begin{array}{l}\text { ezer forint/ } \\
\text { üzem }\end{array}$ & 278,33 & 168,37 & 124,04 & 175,30 & 147,36 \\
\hline $\begin{array}{l}\text { Támogatás } \\
\text { és földbérleti díj a bővített } \\
\text { AEE százalékában }\end{array}$ & százalék & 33,18 & $\begin{array}{l}127,16 \\
(55,32)^{\mathrm{a})}\end{array}$ & 29,81 & 35,62 & 30,90 \\
\hline $\begin{array}{l}\text { AEE a saját fogyasztás, } \\
\text { az ÉCS és a személyi } \\
\text { ráfordítások } \\
\text { beszámításával }\end{array}$ & $\begin{array}{l}\text { ezer forint/ } \\
\text { üzem }\end{array}$ & 838,89 & $\begin{array}{c}132,41 \\
(304,26)^{\mathrm{a})}\end{array}$ & 416,07 & 492,13 & 476,96 \\
\hline A család saját fogyasztása & $\begin{array}{l}\text { ezer forint/ } \\
\text { üzem }\end{array}$ & 27,30 & 86,04 & 87,43 & 77,72 & 249,67 \\
\hline $\begin{array}{l}\text { A saját fogyasztás aránya } \\
\text { a jövedelemböl }\end{array}$ & százalék & 3,25 & $\begin{array}{c}64,98 \\
(28,24)^{\mathrm{a})}\end{array}$ & 21,01 & 15,79 & 52,35 \\
\hline Egyéb jövedelem & $\begin{array}{l}\text { ezer forint/ } \\
\text { üzem }\end{array}$ & 1200,90 & 2532,99 & 2120,05 & 1291,57 & 1093,90 \\
\hline Összes jövedelem & $\begin{array}{l}\text { ezer forint/ } \\
\text { üzem }\end{array}$ & 2039,79 & $\begin{array}{l}2665,40 \\
(2837,25)^{\mathrm{a})}\end{array}$ & 2536,12 & 1783,70 & 1570,86 \\
\hline $\begin{array}{l}\text { Mezőgazdasági } \\
\text { jövedelem aránya } \\
\text { az összjövedelemből }\end{array}$ & százalék & 41,13 & $\begin{array}{c}4,97 \\
(10,72)^{\mathrm{a})}\end{array}$ & 16,41 & 27,59 & 30,36 \\
\hline Mezőgazdasági jövedelem & $\begin{array}{l}\text { ezer forint/ } \\
\text { fö/hó }\end{array}$ & 24,94 & $\begin{array}{c}4,75 \\
(10,93)^{\mathrm{a})}\end{array}$ & 12,02 & 20,29 & 18,83 \\
\hline Egyéb jövedelem & $\begin{array}{l}\text { ezer forint/ } \\
\text { fö/hó }\end{array}$ & 35,71 & 90,81 & 61,22 & 53,26 & 43,19 \\
\hline
\end{tabular}

a) Hozzáadva az igénybe vett szolgáltatások költségét.

Forrás: Tesztüzemi adatok alapján az AKI Vállalkozáselemzési Osztálya

Ha a felhasználható jövedelemre vetítjük az üzemi fogyasztás értékét, jól láthatóan a szociális juttatásból élőknél a legnagyobb a szerepe (több mint 50 százalék), míg a vállalkozóknál elhanyagolható, 3 százalékos szintet ér el. A mezőgazdasági alkalmazottaknál sem jelentős a közvetlen fogyasztás, súlya inkább a viszonylag alacsony jövedelem miatt jelentős, az egyéb alkalmazottak és a nyugdíjasok esetében pedig 15-20 százalékot ér el. Ha ehhez a jövedelemhez hozzávesszük az egyéb (fóállású) jövedelmet, látható, hogy a nyugdíjasoknál és a szociális juttatásból élőknél eléri a 30 százalékot, az alkalmazottaknál a 10-16 százalékot. 
A vállalkozók esetében a mezőgazdasági jövedelem 40 százalékos szintje elsősorban az alacsony bevallott egyéb jövedelemből következik, de ez az érték fenntartással kezelendő (alig magasabb a szociális juttatásban részesülök jövedelménél és megegyezik a nyugdíjasok jövedelmével), mivel a vállalkozói réteg Magyarországon adóoptimalizálási okokból általában a valósnál kisebb jövedelmet vall be.

Ha az üzemi bevételeket a háztartásokban élők számával osztjuk el az év 12 hónapjára, nagyjából reális képet kapunk az egyes csoportok jövedelemszerkezetéről. A szociális juttatásból élők havi 43 ezer forintból élnek, amelyet 18 ezer forintnyi mezőgazdasági jövedelem egészít ki. A nyugdíjasok 53 ezer forintnyi jövedelméhez 20 ezer forinttal járul hozzá a mezőgazdasági tevékenység. Az alkalmazottak 61 ezer forintos egy före jutó jövedelméhez (nem szabad elfeledni a közel egyfönyi eltartottat) 12 ezer forinttal járul hozzá a mezőgazdasági termelésből befolyó jövedelem, míg a mezőgazdasági alkalmazottak 90 ezer forintjához havi 10 ezer forintot tesz hozzá az, hogy rendes munkaidejükön kívül gazdálkodnak. A vállalkozók esetében a havi 24 ezer forintos nettó jövedelem reálisnak tekinthető, a 35 ezer forintos fő jövedelem már kevésbé.

Összességében jól látható, hogy a mezőgazdasági tevékenység a számviteli értelemben vett fontosságánál jóval nagyobb súlyt képvisel az ezt végző háztartások életében, bár az is jól látható, hogy csak kiegészítő szerepe lehet a többi jövedelemforráshoz képest. Ennek ellenére azonban megállapíthatjuk, hogy azon háztartások, amelyek csupán szociális segélyt vagy nyugdíjat kapnak, akár 30 százalékkal is alacsonyabb jövedelemmel rendelkezhetnek, amelyet más tevékenységből (különösen a hátrányos helyzetủ vidéki kistérségekben) aligha tudnak megszerezni. A mezőgazdasági termelötevékenység tehát nemcsak morális értelemben vett értékteremtő szerepe miatt fontos (az ember maga is részese jövedelmeinek alakításában, és nem csupán mások döntenek jövedelmének szintjéről; tevékenyen, hasznos munkát végezve tölti napjait), hanem jövedelmi-megélhetési szempontból is kulcsszerepet játszik abban, jut-e az asztalra hús, gyümölcs, vagy sikerül-e elegendő tüzifát venni a télre.

A mezőgazdasági tevékenység jövedelmi hatását vizsgálva felmerül a kérdés, hogy ha ilyen nagy mértékben, 30 százalékkal is képes növelni a háztartás jövedelmét, miért ilyen alacsony az e tevékenységet folytató és szociális juttatásból élők száma. A 2010-es ÁMÖ szerint a munkanélküli segélyből és egyéb szociális transzferből élők közül nagyságrendileg 25 ezren folytattak 4000 euró STÉ-t meg nem haladó mezőgazdasági tevékenységet (ebből 2400 szociális segélyből élő termelt 2000-4000 euró STÉ között), miközben a vidéki munkanélküliség és a segélyezettek száma ennél nagyságrendekkel nagyobb, több mint 300 ezer volt ebben az időszakban (Biró et al., 2012).

A magyarázat részben a müvelhető terület, a forgóeszközök (állatállomány, vetőmag, palánta, kézi munkaeszközök), részben a szaktudás hiányára vezethető vissza. Utóbbi különösen az újabb generációk esetében jelentős, azaz az életkorral is erős összefüggést mutat. Nem véletlen, hogy bár a szociális segélyből élők átlagéletkora 55 év, a mezőgazdasági tevékenységet végzőké 40 év körüli, ami jelzi, hogy a gazdálkodáshoz szükséges tudás a régebbi generációban még megvan, az újabból viszont már hiányzik. Így ennek a rétegnek olyan komplex programra lenne szüksége, amely nem csak a forgóeszközöket, de a gazdasági ismereteket is képes átadni. 



\section{A kistermelői kör mélyinterjús felmérésének eredményei}

A kisgazdaságok müködési jellegzetességeinek feltárása céljából strukturált mélyinterjúkat készítettünk az ország három megyéjében (Somogy, Tolna, Heves) tevékenykedő kistermelők körében. A kis elemszám miatt elemzésünk alapvetően leíró jellegü. Ahol erre lehetőség kínálkozott, a gazdálkodással kapcsolatos változások nyomon követése végett a kistermelök által szolgáltatott adatokat összevetettük a tesztüzemi felmérés keretében gyüjtött információkkal. A minta kiválasztásának szempontjait a 3 . fejezetben ismertettük részletesen.

\section{A gazdálkodás okai}

A felmérés eredményei szerint a kistermelők meghatározó hányada több évtizede folytat mezőgazdasági tevékenységet, gyakorlati tapasztalatnak, hozzáértésnek nincsenek híján. A gazdaság indulásának körülményeit tekintve a kistermelők két csoportja különíthető el. A gazdaságvezetők szük fele (12-ből 5 fö) a rendszerváltást megelőző időszakban alapította gazdaságát, gyakorta a helyi nagyüzem által müködtetett háztáji integrációs rendszer keretében folytattak sertés-, baromfi-, nyúltartást, gyümölcs- és zöldségtermesztést. A kistermelök másik csoportja (12-ből 7 fö) a rendszerváltást követően jutott termelési erőforrásokhoz (földterülethez, erőgépekhez), amelyek a csökkenő jövedelmek kiegészítésére kínáltak lehetőséget.

\section{8. ábra: A mezőgazdasági tevékenységet motiváló tényezők ${ }^{a)}$}

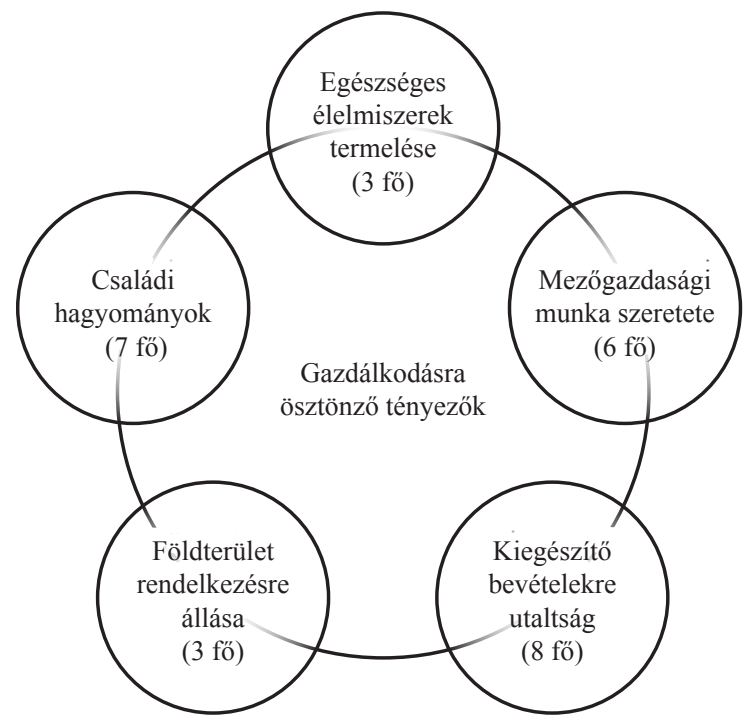

\footnotetext{
a) Említések száma.

Forrás: Kistermelői adatfelvétel alapján AKI
}

Felmérésünk eredményei szerint a gazdálkodói tevékenységet motiváló főbb tényezők sorrendben a kiegészítő bevételekre utaltság, a családi hagyományok, valamint a mezőgazdasági munka iránt érzett szeretet (8. ábra). A gazdálkodási tevékenységet ösztönző, de kisebb jelentőségű tényező a termelési erőforrások rendelkezésre állása ( $\mathrm{pl}$. művelésbe vonható kiskert, eszközök, állattartásra használható épületállomány) és a saját fogyasztásban hasznosítható alapanyagok, élelmiszerek elöállításának szándéka. További mezőgazdasági tevékenységre késztető tényező a gazdálkodás presztízse, a természet szeretete, valamint a földterületek karbantartásával kapcsolatos lakossági elvárások. 


\section{Termelési erőforrásokkal való ellátottság}

A kisgazdaságok által használt földterület mérete jelentős szóródást mutat: a többség (12-ből 7 fö) 5 hektárnál kisebb területet müvel, de akadnak (12-ből 2 fö) több mint 25 hektár szántóterületen gazdálkodók is. A megmủvelt földterület tulajdon, illetve használati forma szerinti megoszlása változatos: a saját tulajdonban lévő terület a legjellemzőbb (12-ből 10 fó), de a bérlet ( 5 fö) és a szívességi használat (3 fö) sem ritka. A különböző földhasználati formák kombinációja a vizsgált kisüzemek körében négy esetben fordult elö, ezek egyik felében a termelők a saját tulajdon mellett bérlet és szívesség fejében használt területet is müvelésbe vontak, másik felében a saját tulajdonú területet bérlet egészítette ki. A szívességi használat legtöbbször a föld megmủvelésére, más ágazatban végzett munkája, életkora miatt nem vállalkozó rokonoktól, ismerősöktől „kölcsön kapott” területre terjed ki. Akad olyan kistermelö, aki 8-10 zártkertet használ szívesség fejében. A szívességi használat, miközben optimalizálja a termelési költségeket, gátját képezi a gazdasággal kapcsolatos fejlesztéseknek. A földterületek müvelésénél tulajdoni és használati formától függetlenül jelentkező nehézség a parcellák széttagoltsága, valamint a területbővítés lehetőségeinek korlátozottsága. Egy 2 hektáros saját földterülettel rendelkező roma család például teljes területét dióval telepítette be, ezért a saját fogyasztásra és eladásra hizlalt 6-8 sertést vásárolt takarmánnyal kénytelenek etetni.

A felkeresett kisgazdaságok mindegyike rendelkezik a mezőgazdasági tevékenység folytatásához szükséges alapvető eszközökkel, kéziszerszámokkal. Az elektromos, robbanómotoros eszközökkel (pl. rotációs kapa, darálógép, motoros permetezőgép) való ellátottság is általánosnak mondható (a 12-böl 9 üzemre jellemző). Erőgépekkel a vizsgált gazdaságok fele rendelkezik. A képet árnyalja, hogy a jórészt kis teljesítményü erőgépállomány elöregedett és az eszközök cseréjére, karbantartására nem vonhatók be források. Egy kombájnkezelő végzettségü, 1996 óta gazdálkodó kistermelő például korábban szolgáltatást is vállalt a helyi nagyüzemből privatizált MTZ-vel, a felújításra szoruló gépet azonban ma már csak a saját földterületek müvelése során hasznosítja.

\section{Termelési szerkezet és működési forma}

A termelési szerkezetet tekintve a megkérdezett kistermelők többsége (12-ből 10 fö) egyidejüleg foglalkozik növénytermesztéssel és állattenyésztéssel. Jellemzően kalászos gabonaféléket, szemes kukoricát, lucernát, valamint gyümölcsféléket termesztenek, az állatok közül a baromfi- és a sertéstartás gyakori, de előfordul juh-, nyúl-, kecske-, valamint lótartás is. A kisüzemek termelési szerkezete változatos, túlnyomó többségük (12-ből 9 fö) háromnál több termékfajtát állít elő, de akadt olyan kisgazdaság is, ahol a termékszerkezet egy híján tíz termékből tevődött össze. Általában véve a diverzifikált termékskála annál jellemzőbb, minél inkább a háztartás saját fogyasztási szükségleteinek kielégítésére termel a gazdaság.

A termelési szerkezet diverzifikáltságából konklúzióként az a tanulság is levonható, hogy a több lábon állás nagyon fontos a kistermelők számára, mert ha az időjárás nem kedvező a növénytermesztésnek, az állattartásból még mindig számottevő bevételek származhatnak. Jó példaként említhető az a termelő, aki 26 hektár területen gazdálkodik, kalászos gabonát termel az állatai (baromfi, sertés) számára, valamint 20,5 hektár gyepterületen 45 juhot tart. A bárányt és a hízósertést értékesíti, amiből a család jövedelmét egészíti ki.

A megkérdezett kistermelők szük feléhez (12-ből 5 fö) nem kapcsolható semmilyen, a gazdálkodásnak keretet adó szervezeti forma. Öt kistermelő őstermelőként foglalkozik mezőgazdasággal, mindegyikük 5 hektárnál nagyobb földterületet müvel. Egyetlen, a nyolcvanas évek közepe óta dísznövénytermesztéssel foglalkozó gazdaságvezető végezte tevékenységét egyéni vállalkozóként. Felmérésünk alapján a mezőgazdasági végzettség és a müködési forma között szoros a kapcsolat: a mezőgazdasági képzettséggel rendelkezők - legyenek közép- vagy felsőfokú végzettségüek - túl- 
nyomórészt bejegyzett őstermelők, ellenben a csak gyakorlati tapasztalat birtokában gazdálkodók semmilyen, a gazdálkodásnak keretet adó szervezeti formával nem rendelkeznek.

\section{A gazdaságvezetők szociodemográfiai összetétele}

A felmért gazdaságok vezetőinek zöme (12-ből 9 fö) férfi, a nők jellemzően segítő családtagként vesznek részt a gazdálkodásban. A gazdaságvezetők közül ketten egyetemi, főiskolai diplomával, heten középfokú végzettséggel rendelkeznek, három válaszadó általános iskolát végzett. A mezőgazdasági szakképzettség tekintetében kedvezőtlenebb a helyzet: a válaszadók közel felének nincs semmilyen agrárvonatkozású képesítése. Egy gazdálkodó alapfokú, négy középfokú szakmai végzettséggel rendelkezik, két gazdálkodó mezőgazdasági szakirányon szerzett diplomát. Bár a megkérdezett kistermelők szakképzettségi szintje nem éppen kedvező, a mezőgazdasági gyökerek kettő kivételével mindegyikük családjában fellelhetők. Kilenc kistermelő valamelyik „,elmenője” korábban gazdálkodott. A csak gyakorlattal rendelkező termelők számára a tapasztalatszerzésre a családi gazdaság mellett a helyi mezőgazdasági nagyüzem kínált lehetőséget, ahol főként a jószágtartásban kamatoztatható szaktudást halmoztak fel. Egy több évtizedig nagyüzemi állattartásban tevékenykedő nyugdíjas kistermelö például ma is önállóan végzi a herélést, segíti az elletést, betegség esetén injekciózza a jószágot.

Az életkori jellemzőket tekintve a vizsgált gazdaságvezetők többsége (12-ből 8 fó) 60 év fölötti (9. ábra). Életkora alapján négy kistermelő az aktív korosztályhoz tartozik, közülük azonban csak egy fő látja el teljes munkaidőben (napi 8 órában), fóállású őstermelőként a gazdaságvezetői feladatokat, amelyet 26 hektáros gazdasága alapoz meg. Két aktív korú termelő helyi mezőgazdasági vállalkozások alkalmazottjaként egészíti ki jövedelmét a kistermelésből, egy fő mezőgazdaságon kívüli munkahely mellett gazdálkodik.

\section{9. ábra: A gazdaságvezetők és a gazdaságban munkát végzők életkor szerinti jellemzői}

Gazdaságvezeto

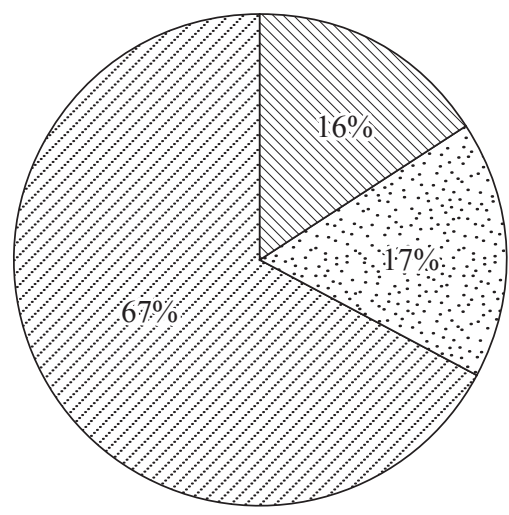

40 év alatt
Gazdaságban munkát végzők

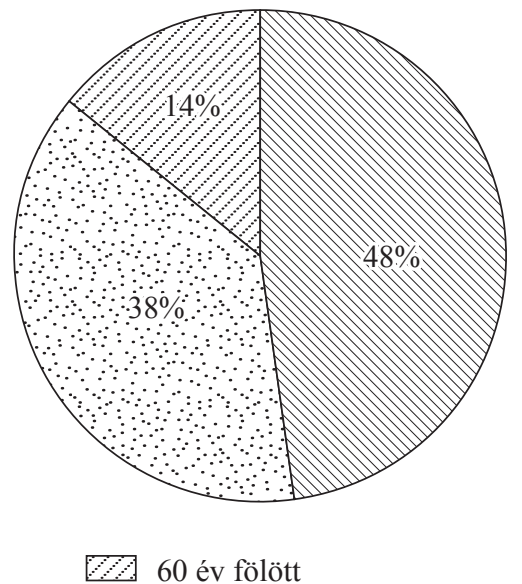

Forrás: Kistermelői adatfelvétel alapján AKI

A gazdaságban felmerülő munkaerőigények kielégítésében kulcsszerepet töltenek be a családtagok. A vizsgált kisüzemek a gazdaságvezetőn felül átlagosan két családtag (1,75 fö) munkaerejét hasznosítják, jellemzően heti 5-10 órás munkavégzés keretében. A gazdaságban munkát végzők korösszetétele a gazdaságvezetőkénél lényegesen kedvezőbb: közel felük a 40 évesnél fiatalabb korosztályhoz tartozik. Gyakori a „többgenerációs” gazdálkodás, ami a tudás felhalmozását, tapasztalatátadást tesz lehetővé. 
Idegen munkaerő foglalkoztatása a vizsgált kisgazdaságokban szinte egyáltalán nem jellemző, ahol előfordul, ott is kizárólag szívességi alapon foglalkoztatnak néhány főt szezonmunkák idején. A kölcsönös segítségnyújtáson alapuló munkavégzés általában a helyben lakó szomszéd termelők, rokonok körében jellemző. Arra is van példa, hogy a kistermelök fölös munkaerejüket a helyi nagyobb mezőgazdasági vállalkozóknál hasznosítják viszontszolgáltatásért cserébe. Egy kisvejkei roma család például saját gazdaságában végzett munkája mellett rendszeresen vállal szezonmunkát a helyi gyümölcstermesztéssel foglalkozó vállalkozásoknál, gépi szolgáltatásokért cserébe.

\section{Termelési célok szerinti jellemzők}

A megkérdezett kistermelök közül négy elsősorban árutermelő kisüzem, azaz a mezőgazdasági tevékenység során keletkező termékek több mint felét értékesíti. Három gazdaság kizárólag saját fogyasztásra, öt pedig saját fogyasztásra és értékesítésre egyaránt termel, azaz a mezőgazdasági termékek több mint felét a család fogyasztja el és csak a felesleget értékesítik.

A kizárólag saját fogyasztásra termelő kisüzemek közös jellemzője, hogy mindössze fél hektár földterülettel rendelkeznek, mindannyian baromfit, illetve két-három hízót tartanak. E háztartások további jellemzője, hogy igen alacsony a megélhetésük színvonala, egyiküknek az alapvető szükségletek kielégítésére is alig futja, a másik kettőben az előre nem kalkulálható eseti kiadások már gondot jelentenek.

Öt kistermelő a gazdaságban megtermelt termékei kevesebb mint felét értékesíti, nagyobb része saját fogyasztásra kerül. Ezekre a gazdaságokra a néhány (2-8) hektáros földterület jellemző, valamint az, hogy mindegyikük tart néhány hízót, illetve egyikük juhokat. Az öt gazdaságvezetö közül három 40 év körüli, kettő 60 év fölötti. Az iskolai végzettség és a mezőgazdasági szakképzettség tekintetében ez a gazdaságcsoport rendkívül heterogén, mind az alap-, a közép- és a felsőfokú képzettség jellemző körükben. Megélhetésük színvonalára is a heterogenitás jellemző, a napi megélhetési gondokkal küzdő családtól a nagyobb összegű megtakarításokra, extrakiadások finanszírozására is képes háztartásig több típus megtalálható közöttük.

Az árutermelő üzemekre - az üvegházi dísznövénykertészetet kivéve - a nagyobb (13-27 hektár), főként saját tulajdonú földterület a jellemző. A három állattartással is foglalkozó gazdaság közül kettő csak baromfit tart, azt is csak saját fogyasztásra. Egy árutermelö kisüzem többféle állatfajt, sertést, juhot, kecskét, baromfit tart. A bárányokat exportra, az évi 1-2 hízót és 10-15 malacot helyben értékesíti. A dísznövénykertész kisüzem olyan értelemben speciális, hogy profiljából adódóan saját fogyasztásra nem, csak értékesítésre termel, ugyanakkor gazdasági méretét tekintve részmunkaidős kisüzem, ahol a gazdaságban előállított jövedelem a háztartás bevételeinek közel ötödét adja. Az árutermelő gazdaságok vezetői közül három 70 év körüli, egyikük 38 éves, közép- vagy felsőfokú iskolai végzettségűek és egy kivételével közép- vagy felsőfokú mezőgazdasági szakképesítéssel is rendelkeznek. E gazdaságok közül háromban a válaszadók biztonságosnak ítélték a család megélhetését, ugyanakkor jövedelmükből csak szerény mértékben képesek megtakarítani. Egy gazdálkodó ítélte ennél magasabb színvonalúnak háztartása megélhetését.

A kisgazdaságok termékértékesítési gyakorlatában a helyben, a településen vagy környékén, közvetlenül a fogyasztóknak, illetve takarmány esetében a helyi állattartóknak történő értékesítés az általános. Egyedül a juhtenyésztéssel foglalkozó gazdaságokra jellemző, hogy a bárányokat exportra értékesítik közvetítő kereskedőkön keresztül. Az árutermelő gazdaságok a termékértékesítés során többnyire stabil felvásárlói körre támaszkodnak, „,megrendelésre” termelnek gyümölcsöt, zöldséget, hizlalnak sertést, baromfit. Egy Tolna megyei kistermelő például hetente szállít Bonyhádra 80-100 tojást, amit évek óta ugyanannak a felvásárlónak értékesít. A muskátlira, petúniára, valamint begóniára szakosodott dísznövénykertész sem a virágpiacra hordja termékeit, a vevők házhoz jönnek. Egy kistermelő megrendelésre hizlal sertést, amit igény esetén konyhakészre feldolgoz. 
A kistermelők körében azt is felmértük, hogy milyen alaptevékenységen kívüli, de a gazdasághoz kapcsolódó tevékenységet végeznek. Összesen három válaszadó jelezte, hogy mezőgazdasági gépi szolgáltatást végez, elmondásuk szerint kizárólag szívességi alapon, helyben élő rokonoknak, barátoknak, ismerősöknek. Egy Somogy megyei kistermelő az MTZ-jével nemcsak a helyi kisüzemeknek szolgáltat, hanem egy helyi nagyobb vállalkozónak is, aki kombájnmunkával „honorálja” a kapott szívességet. Valamilyen mértékü termékfeldolgozást szinte minden kistermelő folytat, zömmel saját fogyasztásra: disznót vágnak, lekvárt föznek, szörpöt, befőttet, bort készítenek. Egy gazdaság a két hektáron megtermett dió egy részét tisztított, feldolgozott formában értékesíti. Egy másik kistermelő gyógynövénygyüjtéssel foglalkozik, így jut kiegészítő bevételhez. Turisztikai vagy egyéb szolgáltatás nyújtásával, szállásadással egyik kisgazdaságban sem foglalkoznak.

\section{Üzleti kapcsolatrendszerek, együttmüködések}

A kistermelők körében nem jellemző a formalizált termelői szerveződésben való részvétel. Ugyanakkor az együttmüködések informális, bizalmi alapon szervezödő kölcsönös szívességi szolgáltatásokban, segítségnyújtásban megnyilvánuló formáit széles körben majdnem mindegyik kistermelö alkalmazza. A szívességi földhasználat, a gépkölcsönzés vagy gépi szolgáltatások nyújtása, szüret vagy aratás idején a szívességi munkavégzés nem csak a rokonok, de a gazdatársak körében is bevett gyakorlat. Az általunk vizsgált üzemek méretüknél fogva általában túl kicsik ahhoz, hogy valamely integrátor szervezethez kapcsolódjanak. Ahol azonban a termelésszervezésben szerepet vállaló nagyobb mezőgazdasági vállalkozások működnek, gyakori az együttmüködés. Az egyik kistermelő például arról számolt be, hogy a helyi téesz-utódszervezet nemcsak a gépi szolgáltatásokat nyújtja a gazdaságnak, hanem az üzleti érdekeinek megfelelő termelési szerkezet kialakítását is ösztönzi. A nagyüzem profiljához illeszkedő termelési szerkezet a kistermelők szempontjából időben elvégzett szolgáltatásokat, szervezett termékértékesítést eredményez. Egy Kárpátaljáról áttelepült család két tagja például a helyi nagygazdaságnál végzett fő́llású munka keretében a vetéstől a betakarításig kedvezményes szolgáltatásokhoz fér hozzá. A szolgáltatásokat a család munkaidőtől függetlenített rendelkezésre állással honorálja a nagygazdaságnak.

A megkérdezett kistermelők közül mindössze hárman jelezték, hogy tagjai valamilyen termelöi szerveződésnek. A két juhtenyésztéssel foglalkozó gazda a Magyar Juh- és Kecsketenyésztők Szövetségének tagja, ők az együttmüködés előnyét elsősorban a piaci információhoz jutásban látják. Egy termelő a helyi szociális szövetkezetben rendelkezik tagsággal, amelyet egy nagyobb (50 hektáros) gazdasági társaság hozott létre. A cég által müködtetett, LEADER-forrásból kialakított termelői piacon heti rendszerességgel, valamint havonta megrendezett vásárokon mutathatják be és értékesítik termékeiket a helyi termelők, kézmüvesek. A vállalkozás feldolgozó üzemében a helyben termett gyümölcsökböl állítanak elö szörpöket, amit a cég által üzemeltetett büfében árusítanak.

\section{Jövedelmi helyzet, megélhetési színvonal}

A kistermelésben részt vevő háztartások bevételi szerkezete jórészt gazdasági aktivitásuk függvénye. Hét háztartásban a fö bevételi forrást a nyugdíjak jelentik, bérjellegü jövedelemmel hat, szociális ellátásból származó bevétellel három háztartás rendelkezik. A kistermelők jövedelmeinek átlagosan 15-20 százaléka származik gazdálkodásból. Mindössze egy olyan, nyugdíjas háztartástagokból álló üzem szerepelt a mintában, ahol ezt meghaladó (40 százalék) volt a gazdálkodásból befolyó bevétel. Esetükben a használt földterület nagysága jelentősen meghaladta a mintaátlagot (elérte a 26 hektárt).

A kistermelők háztartásuk kiadásainak bő negyedét fordítják a gazdaságra, de három olyan háztartás is akadt, ahol a gazdálkodási kiadások elérték az összes kiadás 40 százalékát. Mindhárom üzemben jelentős forgótőke-igényü árutermelő tevékenységet folytatnak. A gazdaság fejlesztésére fordítható források elsősorban ott képződnek, ahol munkabérből származó jövedelem is rendelkezésre áll, illetve ahol a mezőgazdasági termékeket részben vagy egészben értékesítik. Hozzá kell 
tennünk, hogy a vizsgált gazdaságok pénzügyeinek nyomon követése a nem forintosítható családi, rokoni segítségnyújtáson, kölcsönös szívességeken, természetbeni szolgáltatásokon alapuló gazdálkodási gyakorlat miatt csak korlátozottan volt lehetséges.

A kistermelők többsége szerény körülmények között él, nemcsak a gazdaság, de a ház, a közvetlen lakókörnyezet korszerüsítésére, fejlesztésére sem állnak rendelkezésre források. A felmérésben mindössze két olyan gazdaság szerepelt, amelyben a család jövedelme a jelentősebb megtakarításokhoz, az életminőség emeléséhez is fedezetet nyújt. E gazdálkodók egyike agrármérnöki tudását a nyolcvanas évek közepén kialakított dísznövénykertészetben kamatoztatja, emellett szaktanácsadást, pályázatírást is végez. A másik gazdaságban a családtagok egy helyi nagygazdaság alkalmazottjaként a gazdasággal kapcsolatos kiadásokat alacsony szinten tartó, kedvezményes mezőgazdasági szolgáltatásokban (talajmunkák, inputanyagok) részesülnek.

\section{Jövőre vonatkozó tervek, fejlődési irányok}

Az üzemek jövőjét tekintve a vizsgált gazdaságokból nyolcban terveznek fejlesztéseket (10. ábra). Négy gazdaságban állattenyésztési tevékenységgel bővítenék a termelési profilt, ehhez rendelkeznek a szükséges tapasztalattal, épületállománnyal, a takarmány megtermelése azonban valamennyiük számára gondot jelent. Négy gazdaságban gépberuházásokat (traktor, bálázó beszerzése) terveznek, amellyel lehetőség szerint szolgáltatásokat is végeznének.

\section{0. ábra: A gazdasággal kapcsolatos tervek ${ }^{\text {a) }}$}

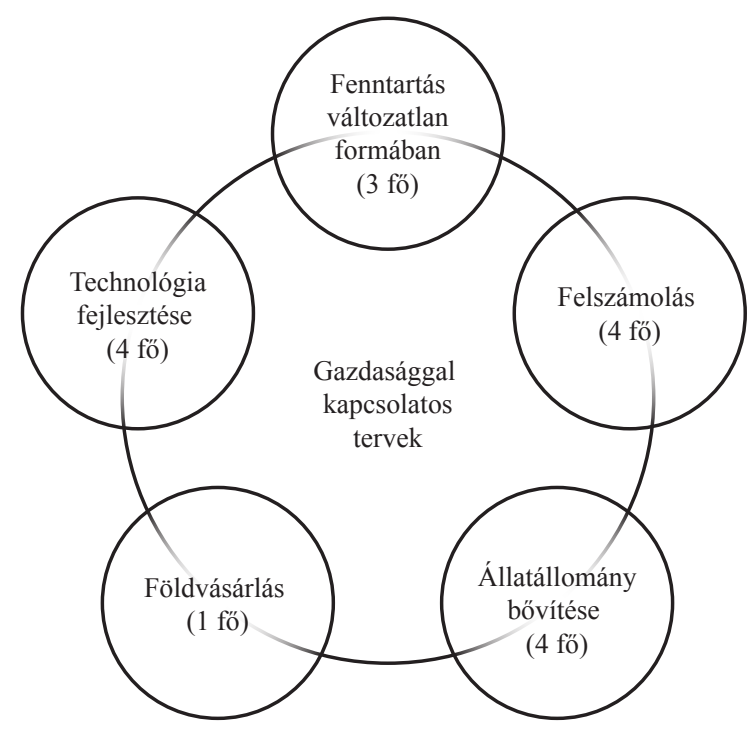

a) Említések száma.

Forrás: Kistermelői adatfelvétel alapján AKI 
A fejlesztési tervek realizálásának elsősorban a saját forrás hiánya, valamint a külső források, hitelek magas költségei szabnak gátat. Négy üzemben a gazdaság felszámolása merült fel a gazdaságvezetők, illetve a gazdaságban munkát végzők idős kora, az utánpótlás hiánya miatt. Mindössze két gazdaság rendelkezett mezőgazdasági pályára készülő utódokkal, akik iránt a nagyobb mezőgazdasági vállalkozások is élénk érdeklődést mutatnak. Egy esetben a középkorú gazdaságvezető azért vette számításba a gazdaság felszámolását, mert a szolgáltató szektorban helyezkedett el alkalmazottként, ami a mezőgazdasági tevékenység fenntartását nehezíti. Komplex, a technológia fejlesztését, az állatállomány, valamint a földterület bővítését is magában foglaló fejlesztést mindössze egy üzemben terveznek, amelyet a gazdaságvezető életkora (44 év), felsőfokú mezőgazdasági végzettsége, valamint 5 hektáros földterület (amelynek fele saját) alapoz meg.

Az interjúk során a kisüzemek eddigi fejlődéstörténetét, fejlődésének irányait is feltártuk. A 12 gazdaság közül háromban az elmúlt időszakban nem történt érdemi változás, a tevékenységszerkezet, valamint az üzemméret nem változott, a bevételek stagnáltak. Öt gazdaságban az üzemméret a termelési szerkezet egyszerüsödésével párhuzamosan csökkent. Négy kisgazdaság tudta az elmúlt öt évben üzemméretét növelni. Közülük két üzemben a méretnövekedés a termelési szerkezet bővülésével, két esetben jelentős egyszerüsödésével járt együtt (35. táblázat).

\section{5. táblázat: A kisgazdaságok jellemzői fejlődési irányuk alapján}

\begin{tabular}{cccc}
\hline \multirow{2}{*}{ Üzemméret } & \multicolumn{3}{c}{ Termelési szerkezet } \\
\cline { 2 - 4 } & Bővült & Nem változott & Egyszerúsödött \\
\hline Nőtt & 2 gazdaság & 2 gazdaság \\
\hline Nem változott & & 3 gazdaság & 5 gazdaság \\
\hline Csökkent & & & \\
\hline
\end{tabular}

Forrás: Kistermelői adatfelvétel alapján, AKI

Mélyinterjúkon alapuló vizsgálatunk eredményeit összefoglalva, a kisgazdaságok körében három fejlődési irány azonosítható:

1. A kistermelők szük fele utód hiányában, valamint a gazdaságon kívül végzett jövedelemtermelö tevékenységek miatt fokozatosan leépíti gazdaságát. A gazdaság akár több évig is elhúzódó felszámolásának fázisait a termékszerkezet szükítése, az élő munkát nem igénylő, illetve kisebb termelési kockázattal járó tevékenységek megtartása, végül a földterületek bérbeadása, értékesítése jelenti.

2. A stagnáló kisgazdaságok a termék- és tevékenységszerkezet megtartása mellett, a termelési erőforrások bővítése, fejlesztése nélkül müködtetik gazdaságukat. E gazdaságokban a kistermelésből származó, saját fogyasztásra előállított termék, illetve a termékértékesítésből származó jövedelem a háztartás jövedelemszerkezetének nehezen nélkülözhető része. A gazdaságba történő beruházás korlátját elsősorban a saját tőke hiánya, valamint a külső források (pályázatok, hitelek) elérésének nehézségei jelentik.

3. A növekedésorientált árutermelö kisüzemek körében két fejlödési pálya körvonalazható: az egyenletesebb munkaerö-lekötést és jövedelemtermelést lehetővé tevő tevékenységdiverzifikáció, valamint a veszteséges, munkaerő-igényes tevékenységek leépítésével járó specializáció. A két altípus között nemcsak a termelési szerkezet, hanem a munkaerő-felhasználás, valamint a megtermelt termékek célpiacai terén is különbségek mutatkoznak. A tevékenységdiverzifikációval jellemezhető kistermelőket összetett termékstruktúra, a gazdaságba beforgatható (zömmel családi) munkaerő bősége, valamint a túlnyomórészt lokális piacokra termelés jellemzi. A specializált kisüzemeket a termékskála vonatkozásában egynemüség, korlátozottan rendelkezésre álló munkaerő-kapacitások, valamint szervezett, gyakorta településen kívüli piaci kapcsolatok jellemzik. 
Fejlődési potenciál mind a növekedésorientált, mind a stagnáló kisüzemek körében mutatkozik, ennek kihasználásához azonban szükséges a termelési erőforrások korszerüsítése, a kapacitások bővítése, valamint a termelési folyamat biztonságát és az alkuerőt együttesen növelő (REL-típusú, integrátori) termelői-értékesítői hálózatokba tagozódás.

\section{A tesztüzemi rendszer és a mélyinterjús tapasztalatok kapcsolata}

A költség- és bevételi szerkezetre vonatkozó interjús válaszokat összevetettük a kisgazdaságok tesztüzemi adatszolgáltatás keretében nyújtott adataival. A tapasztalatok szerint a gazdasággal kapcsolatos bevételi és kiadási tételek nehezen meghatározhatók, mivel összemosódnak a háztartás egyéb költségvetési tételeivel. Míg az interjúk alkalmával a válaszadók úgy nyilatkoztak, hogy a gépi szolgáltatásokat többnyire szívességi alapon végzik, addig a tesztüzemi adatok alapján ez a tétel az üzemi költségek átlagosan bő 10 százalékát tette ki. Az összes üzemi költség legnagyobb hányadát (több mint felét) az értékcsökkenési leírás teszi ki, második helyen az anyagjellegű ráfordítások szerepelnek.

A tesztüzemi adatok megerősítették, hogy a kisgazdaságokban nem releváns a személyi jellegü ráfordítások elemzése, ugyanis zömmel a családon belül oldják meg a munkavégzést és nem számolnak el bérköltséget. A tesztüzemi adatok azt is megerösítették, hogy a földek bérleti díja nem képvisel jelentős tételt a kisgazdaságok költségszerkezetében, tekintettel arra, hogy a ház mögött található területet, zártkerteket müvelik, vagy a korábbi termelőszövetkezetek jogutódjainak tulajdonában lévő földterületeket használják szívesség fejében.

A bevételeket tekintve a kistermelök az interjúk során sötétebben festették le pénzügyi helyzetüket, mint amit a tesztüzemi adatok jeleznek. Akadnak olyan kisüzemek, amelyek a tesztüzemi adatok két egymást követő évében megkétszerezték a gazdálkodásból származó árbevételüket. A gazdaságban előállított termékek értékének jelentős része (átlagosan harmada) a család saját fogyasztását fedezi, ami egyes üzemekben az 500-600 ezer forintot is eléri. Ez az érték jelentősen csökkentheti a háztartás élelmiszerre kiadott költségeit, ennek ellenére az élelmiszerre fordított költségek a háztartási kiadások legjelentősebb részét, átlagosan 30 százalékát teszik ki.

A gazdaságok többségében az elmúlt öt évben csak kisléptékủ fejlesztések valósultak meg (pl. háti permetező, rotációs kapa vásárlása, erőgépeken gumi cseréje), amelyek forrása minden esetben saját erő volt. Külső források (hitelek, pályázatok) bevonására a kisgazdaságok a termelésből származó jövedelmek alacsony szintje miatt egyáltalán nem vállalkoznak, a beruházások zöme a gazdaság alapításának idejére tehető. Az uniós csatlakozással megnyíló támogatások közül a kistermelők egyedül a KAP I. pillérének közvetlen, területalapú támogatásaihoz fértek hozzá, az egyéb vidékfejlesztési pályázatok a kisléptékü (300-500 ezer forint összegü) fejlesztési igények, valamint a pénzügyi átláthatóság és az egyéb jogosultsági feltételek hiánya miatt elérhetetlenek maradtak számukra.

Összességében megállapítható, hogy a tesztüzemi rendszer számviteli logikája alapvetően az árutermelő gazdaságok profitjának mérését célozza, így az olyan, elsődlegesen nem árutermelő üzemek esetében is megpróbálja „költségesíteni” és „,bevételesíteni” a gazdálkodás egyes folyamatait és elválasztani a személyi jellegű kiadásokat a tényleges profittól, ahol a gazdálkodás döntően nem profitorientáltan müködik. Emellett a „költségesítés” és a „,bevételesítés” a normál piaci viszonyok esetén jellemző árak és költségek mellett kerül megállapításra, így az olyan tételek, amelyek egy normál piacon jelentős költséget jelentenek (pl. munkaidő, értékcsökkenés), komoly pénzügyi teherként csökkentik a tesztüzemi kimutatásban szereplő üzemek jövedelemtermelő képességét, kérdésessé téve a termelés gazdasági racionalitását. Az ilyen üzemek esetében a tényleges helyzet az, hogy a termelő adott mezőgazdasági inputra (munkaidő, ingatlan vagy gép javítási költsége, bérleti 
díj, mezőgazdasági szolgáltatás díja) vonatkozó saját lehetőségköltsége drasztikus mértékben eltér a normál piaci ártól (például mert zsákfaluban lakva nem képes elhelyezkedni, így munkaideje alternatívaköltsége 0 forint; mert a disznóól javítási költsége a szomszéd romház alapanyagát felhasználva 0 forint; mert a szomszéd idős házaspár még hálás is, ha valaki lekaszálja a kertjében a gazt, így a bérleti díj és a takarmányköltség 0 forint). Ennek megfelelően az adott termelő a legracionálisabban jár el azzal, hogy mezőgazdasági kisüzemi termelést végez, ez viszont a számviteli adatokból nem azért nem látszik, mert rossz a módszer, hanem azért, mert nem megfelelő az árazás. Ha viszont az árazás korrigálásra kerül, láthatóvá válik a gazdálkodás racionalitása. 



\section{A mezőgazdasági kisüzemek megjelenése a fejlesztéspolitikában}

Ebben a fejezetben azt vizsgáljuk, hogy milyen ösztönzők, támogatások, fejlesztési programok segítették, illetve segítik a jövőben a vidéki térségekben élő, mezőgazdasági tevékenységet folytató kistermelői kört. Az áttekintésben kitérünk a kistermelők tevékenységét közvetlenül érintő adópolitikai eszközökre, a mezőgazdasági kisüzemek árutermelővé válását célzó támogatási formákra, másrészt azokra a mezőgazdasági tartalmú munkaerőpiaci és szociálpolitikai programokra, amelyek elsődleges célja a foglalkoztatási szempontból hátrányos helyzetü vidéki népesség munkaerőpiaci reintegrációja vagy akár csak megélhetésének segítése.

A kistermelők tevékenységét befolyásoló adózási szabályok értelmében azon mezőgazdasági termelőknek, ${ }^{11}$ akiknek őstermelői tevékenységből származó éves árbevétele nem haladja meg a 600 ezer forintot, nem kell adóbevallást készítenie és árbevétele után adóznia. További mezőgazdasági östermelőket érintő személyi jövedelemadó-kedvezmény a tételes költségelszámolást vagy a 10 százalék költséghányadot választó mezőgazdasági őstermelők esetében, hogy e tevékenységből származó jövedelmük utáni adó összegéből legfeljebb 100 ezer forint őstermelői adókedvezmény illeti meg őket. A tételes költségelszámolást alkalmazó mezőgazdasági kistermelők ${ }^{12}$ bevételük 40 százalékát - igazolás nélkül - kistermelői költségátalány címén elszámolhatják költségként.

A mezőgazdasági kistermelőket a személyi jövedelemadó-kedvezményeken felül járulékkedvezmények is megilletik. Mezőgazdasági kistermelők esetében a járulékfizetés alapja a minimálbérnél alacsonyabb összegben kerül megállapításra, továbbá mentesülnek a 27 százalékos szociális hozzájárulási adó, illetve a 3 százalékos pénzbeli egészségbiztosítási járulékfizetési kötelezettség alól is.

Az adóügyi szabályozás mellett a kistermelők tevékenységét hivatott segíteni az 52/2010 (IV. 30.) FVM rendelet, amelynek értelmében azon természetes személyek, akik kis mennyiségü, saját maguk által megtermelt, illetve korlátozott mértékben és meghatározott helyen feldolgozott élelmiszert állítanak elő, területi korlátozások mellett közvetlenül is értékesíthetik termékeiket. Az előállított élelmiszerek értékesítését nemcsak a kistermelő végezheti, hanem a vele egy háztartásban élő személy, valamint a kistermelö házastársa, bejegyzett élettársi kapcsolatban élö élettársa, nagykorú gyermeke, testvére, szülője, nagyszülője is (Juhász et al., 2012).

\section{A mezőgazdasági kisüzemek támogatása a vidékfejlesztési programokban}

A többnyire csak saját fogyasztásra termelö, esetenként a piacon is megjelenő mezőgazdasági kisüzemek a 2004-2007 közötti időszakban a Nemzeti Vidékfejlesztési Tervben (a továbbiakban NVT) megfogalmazott „Szerkezetátalakítás alatt álló félig önellátó gazdaságok támogatása” intézkedés keretében vehettek igénybe támogatást. A támogatási formának nem volt hazai előzménye, a mindenkori kormányzat főként az előzőekben tárgyalt adópolitikai eszközökkel (őstermelői, kistermelői kedvezmények) támogatta a kisebb üzemeket. Az NVT keretében elérhető uniós támogatás évente 1000 eurónak megfelelő forintösszeg volt, legfeljebb öt éven keresztül. A támogatás célcsoportját a kisüzemek köréből azok képezték - hozzávetőleg 30 ezer gazdaság -, amelyek kis méretük ellenére „piacorientált” egyéni gazdálkodást folytattak. Az NVT megvalósulását nyomon követő értékelő

\footnotetext{
${ }_{11}$ Mezőgazdasági őstermelő az a 16. életévét betöltött nem egyéni vállalkozó magánszemély lehet, aki a saját gazdaságában az Szja-törvény 6. számú mellékletében felsorolt termékek előállítására irányuló tevékenységet folytat és ennek igazolására őstermelői igazolvánnyal rendelkezik. Mezőgazdasági östermelői tevékenységnek minősül a saját gazdaságban történő növénytermelés, ültetvénytelepítés, állattenyésztés, valamint a termékfeldolgozás is akkor, ha az saját gazdaságban történő alapanyag felhasználásával történik, valamint a saját gazdaságban egyes mezőgazdasági termékek jogszabályba nem ütköző gyüjtése, valamint a saját tulajdonú földterületen végzett erdőgazdálkodás.

${ }_{12}$ Azon őstermelők, akiknek az adóévben az őstermelői tevékenységéből származó éves bevétele nem több 8 millió forintnál, mezőgazdasági kistermelöknek tekinthetök.
} 
jelentés szerint a szerkezetátalakításra benyújtott pályázatok száma a 2004-2007 közötti időszakban mindössze 1140 darab volt a tervezett 12 ezer pályázattal szemben (Respect, 2009) (36. táblázat). A pályázástól való távolmaradás okát az értékelők az összetett, teljesítményhez kötött jogosultsági feltételek (megfelelő gazdaságméret, középfokú szakirányú végzettség, a támogatás ötödik évében elérendő 50 százalékos teljesítménynövekedés) és az alacsony támogatási összeg között fennálló aránytalanságban látták.

36. táblázat: Félig önellátó gazdaságok támogatása az NVT-ben, 2004, 2006, 2007

\begin{tabular}{lrrrrrrrrr}
\hline \multirow{2}{*}{ Megnevezés } & \multicolumn{2}{c}{$\mathbf{2 0 0 4}$} & \multicolumn{2}{c}{$\mathbf{2 0 0 6}$} & \multicolumn{2}{c}{$\mathbf{2 0 0 7}$} & \multicolumn{2}{c}{ Összes } \\
\cline { 2 - 9 } & száma & $\begin{array}{c}\text { aránya, } \\
\text { százalék }\end{array}$ & száma & $\begin{array}{c}\text { aránya, } \\
\text { százalék }\end{array}$ & száma & $\begin{array}{c}\text { aránya, } \\
\text { százalék }\end{array}$ & száma & $\begin{array}{c}\text { aránya, } \\
\text { százalék }\end{array}$ \\
\hline $\begin{array}{l}\text { Kérelmek száma, } \\
\text { darab }\end{array}$ & 1032 & 61,2 & 410 & 24,3 & 243 & 14,4 & 1685 & 100 \\
\hline $\begin{array}{l}\text { Támogatott kérelmek, } \\
\text { darab }\end{array}$ & 716 & 62,8 & 414 & 36,3 & 10 & 0,9 & 1140 & 100 \\
\hline $\begin{array}{l}\text { Kifizetett támogatás, } \\
\text { EUR }\end{array}$ & 710000 & 31,7 & 678730 & 30,3 & 848650 & 37,9 & 2237380 & 100 \\
\hline $\begin{array}{l}\text { Ebböl EMOGA, } \\
\text { EUR }\end{array}$ & 572800 & 62,8 & 331200 & 36,3 & 8000 & 0,9 & 912000 & 100 \\
\hline
\end{tabular}

Forrás: NVT 2004-2006 ex-post értékelés, 2009

Az Európai Unió a szerkezetátalakítás alatt álló félig önellátó gazdaságok támogatására a 20072013 közötti tervidőszakban is lehetőséget kínált az Európai Mezőgazdasági és Vidékfejlesztési Alap terhére. Az Új Magyarország Vidékfejlesztési Program 141. „A szerkezetátalakítás alatt álló félig önellátó gazdaságok támogatása" intézkedése az árutermelésre képes, a piaci követelményeknek megfelelő, de tőkehiányos kisgazdaságok segítését, az általuk végzett mezőgazdasági tevékenység fenntartását és fejlesztését, jövedelemszerzési lehetőségeinek javítását, a gazdaságok árutermelésre való átállásának segítését tüzte ki célul. A kedvezményezetti kör és a támogatási feltételek meghatározása az NVT-hez képest lényegesen nem változott. A támogatási összeget kissé megemelték, évi 1000-ről 1500 euróra, a jogosultsági feltételnél pedig a kiindulási gazdaságméretet 2-5 európai méretegység (EUME) helyett először 2-4 EUME-ben határozták meg, majd később az árbevétel alsó korlátját 1 EUME-re csökkentették. Ezenkívül az NVT-ben megfogalmazott feltételekhez képest a támogatás ötödik évének végére elérendő gazdasági kritériumok határértéke is csökkent, 5-röl 4 EUME-re. A módosítások ellenére végül az intézkedést az ÚMVP keretén belül nem indították el.

A 2007-2013 közötti időszakban a 141. intézkedés mellett a Vidékfejlesztési Program termelői csoportok létrehozását és müködtetését támogató 142. intézkedése támogatta a gyenge piaci integrációval jellemezhető kisüzemek piacra lépését. A tesztüzemi adatbázison, valamint a Mezőgazdasági és Vidékfejlesztési Hivatal támogatási adatain alapuló vizsgálat alapján a támogatott termelői csoportok keretében közel 3000 3-5 EUME közötti méretü kisüzem lépett a piacra és vált a termelői csoporthoz csatlakozás eredményeként árutermelővé (Biró és Rácz et al., 2015).

A 2014-2020-as programozási időszakban az új EMVA-rendelet (1305/2013/EU rendelet) leszögezi, hogy a gazdaságilag potenciálisan életképes mezőgazdasági kisüzemek fejlődését kiemelten ösztönözni kell. Magyarországon a 2014-től 2020-ig tartó időszakban a kisgazdaságok támogatására a Vidékfejlesztési Program ,,6.3. Mezőgazdasági kisüzemek fejlesztése” alintézkedése keretében kerül sor. Az intézkedés a részben piacra termelö, a stabil megélhetés szintjét még nem biztosító, de fejlődőképes kisgazdaságok megerősítésére és legalább egy fö biztos megélhetésének fedezésére irányul. Az intézkedés a mezőgazdasági kisüzemek - egyszerü, de racionális üzleti terv alapján történő - fejlesztését támogatja, különösen, ha ennek célja a meglévő termékszerkezet piaci pozícióinak stabilizálása és a piac igényei szerinti továbbfejlesztése, a termelés korszerüsítése, magasabb hoz- 
záadott érték előállítása, a jövedelem és a foglalkoztatás bővítése. A kisméretű mezőgazdasági tevékenység fejlesztését szolgáló intézkedés elsődleges célja a stabil árutermelő tevékenység ösztönzése. A támogatás a tagállami meghatározás alapján mezőgazdasági kisüzemnek minősülő üzemeknek ítélhető oda. A Vidékfejlesztési Program szerint mezőgazdasági kisüzem az a mikrovállalkozásnak minősülő (jogi vagy természetes személy) mezőgazdasági termelö, akinek mezőgazdasági tevékenységből származó üzemmérete STÉ-módszertan alapján meghaladja az évi 3000 eurót, de nem éri el az évi 6000 eurót, vagy a mezőgazdasági termelésből, illetve mezőgazdasági termelésből és élelmiszer-feldolgozási tevékenységből származó árbevétele meghaladja az évi 3000 eurónak megfelelő forintösszeget, de nem éri el az évi 6000 eurónak megfelelö forintösszeget (Miniszterelnökség Agrárés Vidékfejlesztési Programokért Felelős Helyettes Államtitkársága, 2015).

A támogatás feltétele, hogy a kérelmező egyszerüsített üzleti tervet nyújtson be és az üzleti tervben vállalt legfeljebb négyéves időszak elteltével a mezőgazdasági termelőtevékenységéből származó üzemmérete (STÉ), illetve a mezőgazdasági termelésből és élelmiszer-feldolgozási tevékenységből származó értékesítés nettó árbevétele haladja meg a 6000 eurónak megfelelő forintösszeget.

A támogatás legalább két részletben, legfeljebb öt évig, egyösszegủ átalány formájában nyújtható. Az egyösszegü átalány összegének megállapítása az üzleti terv alapján történik. A maximális támogatás 15000 eurónak megfelelő forint öt évre. Az első alkalommal igényelhető támogatás a teljes összeg 75 százaléka lehet, a támogatás utolsó részletének kifizetési feltétele, hogy legkésőbb a negyedik naptári év végére a gazdálkodó megfelelően teljesítse az üzleti tervben vállalt kötelezettségeket.

A Vidékfejlesztési Program 2014-2020 ,6.2.1. Nem mezőgazdasági tevékenységek elinditásának támogatása" intézkedése keretében azok a mikrovállalkozásnak minősülő mezőgazdasági termelök pályázhatnak legfeljebb 40 ezer euró összegü átalánytámogatásra, akik a gazdasági több lábon állás érdekében mezőgazdasági termelésüket valamilyen új, nem mezőgazdasági tevékenység indításával igyekeznek diverzifikálni. A támogatás feltétele reális, megalapozott üzleti terv benyújtása.

A 6.2.1. intézkedés keretében nyújtott átalánytámogatástól eltérö, legfeljebb 100 ezer euró összegü, beruházási jellegü támogatást is igénybe vehetnek a mezőgazdasági kisüzemek valamilyen nem mezőgazdasági tevékenység fejlesztéséhez $a$, 6.4.1. Nem mezögazdasági tevékenységek fejlesztése" intézkedés keretében. Támogatható többek között termék-, szolgáltatás- vagy technológiafejlesztés, a tevékenységhez kapcsolódó műhely/bemutatótér fejlesztése, interaktív bemutatók tartásához szükséges fejlesztés, árusítóhely kialakítása, fejlesztése, falusi és egyéb vidéki turisztikai attrakció és szolgáltatás továbbfejlesztése.

A kistermelök számára kitörési pont lehet a rövid ellátási láncokban (REL) való részvétel. A REL olyan rendszeres értékesítést végző és legfeljebb egy közvetítő közbeiktatásával alkotott ellátási lánc, amely a termelők együttműködésén alapul, és ahol a termelők és fogyasztók között szoros földrajzi kapcsolat áll fenn. A termelök számára a nagyobb jövedelem, a fogyasztók számára a megbízható és friss termék a motiváló tényező. A 2014-2020-as Vidékfejlesztési Program támogatja a REL-együttmüködések létrejöttét és müködését is. A támogatás egyrészt a közvetlen piacra jutás érdekében új vagy meglévő közös értékesítési csatornák fejlesztésének céljára létrejövő együttműködő csoport megalakulására, például tagok toborzására, üzleti terv kidolgozására irányul. Második ütemben a kidolgozott üzleti terv megvalósításához lehet támogatást szerezni (NAK-Miniszterelnökség, 2015). A csoportot legalább öt mikrovállalkozásként müködő mezőgazdasági termelő és egy piacszervező alkothatja. A piacszervező olyan nonprofit szervezet lehet, amely nem áll üzleti kapcsolatban a termelőkkel, tehát nem minősül beszállítónak, felvásárlónak, bérbeadónak és a projekt, illetve az együttmüködés menedzselését végzi. A támogatás ideje legfeljebb három év, a maximális támogatás 300 ezer euró. 
A kistermelők az EMVA-forrásokon kívül az EMGA forrásaiból is számíthatnak támogatásra a kistermelői támogatási rendszeren keresztül, ami a területalapú támogatást helyettesítő átalánytámogatás. Ez a támogatási rendszer a közvetlen támogatások alternatívájaként jött létre azok számára, akik kisebb területen gazdálkodnak. A rendszer könnyen átlátható, kevesebb adminisztrációval járó, kiszámítható támogatási formát kínál. A támogatás mértéke legalább 500 és legfeljebb 1250 euró/ év. Az első támogatási évben a rendszerbe 50755 gazdaság jelentkezett be. A kistermelői támogatást igénylők közül az egységes területalapú támogatás (SAPS) és zöldítés jogcímben 45153 ügyfél érintett, 5602 ügyfél pedig termeléshez kötött támogatást, fiatalgazda-támogatást is igényelt.

A kisgazdaságok egyszerüsített támogatása a 4000 euró STÉ alatti üzemcsoport mindegyikénél egyértelmű jövedelemnövekedést eredményezhet, és közel kétszeresére emelheti az üzemszintü területalapú támogatást. Mivel a kisgazdaságok mezőgazdaságból származó fogyasztási alapjának nagyjából 30 százalékát teszi ki a területalapú támogatás (kivéve a mezőgazdasági alkalmazottakat), a kétszeres támogatás akár 30 százalékos fogyasztásialap-növekedést is generálhat ezen kisgazdaságoknál, így a nyugdíjasok és a szociális juttatásból élők esetében akár 10 százalékra is rúghat az egyszerüsített támogatásra való áttérésből fakadó jövedelemnövekedés a háztartás összjövedelmén belül.

A Vidékfejlesztési Program különtámogatást biztosít a szociális indíttatású szolidáris gazdálkodásra, valamint a közösség által támogatott mezőgazdaságra vonatkozó programok számára, méghozzá olyan együttműködéseken keresztül, amelyek már müködő mezőgazdasági tevékenységekre épülve, fóként a társadalom hátrányos helyzetű tagjai számára hasznos szolgáltatások szervezését valósítják meg. A Vidékfejlesztési Program 16.9.1. intézkedésének célja a hátrányos helyzetü csoportok reintegrációja, az általuk történő termék-előállítás és a fogyasztók önszerveződő csoportosulásának megszervezése. A támogatott együttmüködések résztvevői egyrészt a gazdálkodó (mezőgazdasági mikrovállalkozás) és az a célcsoport vagy annak szervezetei, amelyre a szolgáltatások irányulnak, valamint a célcsoport speciális szükségleteit szolgáló szakemberek (intézményei). A közösség által támogatott mezőgazdaság keretében a hátrányos helyzetủ csoportok integrációján túli cél a termelők és a fogyasztók önszerveződő csoportosulásának szervezése, együttmüködéseinek kialakítása. A támogatás időtartama legfeljebb három év, a maximális támogatás az együttmüködés szervezésére és müködtetésére 25 ezer euró, az együttmüködés keretében megvalósuló egyedi projekt megvalósítására 80 ezer euró.

\section{A mezőgazdasági tartalmú szociálpolitikai és munkaerőpiaci programok tapasztalatai}

A vidékfejlesztési programokban megjelenő támogatásokon kívül az elmúlt két évtizedben több olyan kisléptékü program indult, amely többnyire hazai, ritkábban uniós pályázati forrásokból, részben magántőke bevonásával valósult meg. E programok célcsoportját a vidéken élő, munkaerőpiacról tartósan kiszorult, alacsony jövedelmü társadalmi csoportok alkotják. A felzárkóztatást mezőgazdasági termelőtevékenység ösztönzésével elérni kívánó programok filozófiája szerint az aktív szociálpolitikai vagy munkaerőpiaci eszközök a passzív ellátásoknál (pl. munkanélküli ellátás, rendszeres szociális segély) hatékonyabban szolgálják a munkaeröpiaci felzárkózást, tekintettel arra, hogy félúton vannak a központilag támogatott foglalkoztatási formák és az elsődleges gazdasághoz kapcsolódó, piaci alapú munkavégzés között. Az alábbiakban a mezőgazdasági érintettségü szociálpolitikai programokat két fő csoportra - központi programok és civil kezdeményezések - tagolva mutatjuk be, kitérve főbb célkitüzéseikre, célcsoportjukra, eszközrendszerükre, finanszírozási hátterükre és elért eredményeikre. 


\section{Központi programok}

\section{Szociális földprogram}

Az egykori Népjóléti Minisztérium által koordinált szociális földprogram kísérleti jelleggel 1992-ben indult, kezdetben két agráradottságú megyére (Békés, Szabolcs-Szatmár-Bereg), a későbbiekben 11 megyére kiterjedően. A területi lefedettség az ország leghátrányosabb helyzetü vidékeinek elhelyezkedését követte: a közel két évtized alatt felhasznált támogatás (3,5-4 milliárd forint) háromnegyede a megélhetési lehetőségek szempontjából legkiterjedtebb válsággócokba, az ÉszakAlföld és az Észak-Magyarország régiókba, ezen belül Szabolcs-Szatmár-Bereg és Borsod-AbaújZemplén megye településeire került. A földprogramot müködtető települések száma éves szinten 180-250 között mozgott.

A szociális földprogramra fordított források az indulástól 2003-ig folyamatosan növekedtek, az uniós csatlakozást követően, erőteljes ingadozás mellett, évente átlagosan közel 200 millió forint támogatást használtak fel a kedvezményezett települések, ami településenként 0,7-1,5 millió forintot jelentett. Bár a program szakmai megvalósulásáért felelős szaktárca részéröl kifejezett szándék volt rá, a program finanszírozásába nem tudtak uniós támogatási forrásokat bevonni.

A szociális földprogramokban a termelési szerkezetre a magas hozzáadott értékkel és kézimunkaerő-igénnyel jellemezhető zöldség- és gyümölcstermesztés túlsúlya jellemző. Népszerű a burgonya termelése, de több helyen foglalkoznak palántaneveléssel, vetőmag-elöállítással is. A szántóföldi növénytermelés a jóval szerényebb jelentőségü állattartás (sertés, baromfi) takarmányszükségletének kielégítésére irányul. Az állattenyésztési programok kevésbé sikeresek, ennek okát a résztvevők állattartással kapcsolatos hiányos ismeretei, valamint a takarmány termesztésének, beszerzésének földterület- és forráshiánnyal összefüggő korlátai jelentik (Rácz, 2013).

A szociális földprogramok keretében megmüvelt földterület zöme önkormányzati tulajdonban/ használatban lévő parcella (Márkusz és Tóth, 2010). Az eddigi tapasztalatok alapján a szociális földprogramok a kedvezményezettek munkaeröpiaci esélyeit csak mérsékelten javítják, inkább a megélhetés alapjául szolgáló, túlnyomórészt szezonálisan jelentkező jövedelmek bővítéséhez járulnak hozzá. A szociális földprogramot 2011-ben összekapcsolták a közfoglalkoztatással, oly módon, hogy a földprogramot megvalósító önkormányzatok a támogatás összegétől függően közfoglalkoztatást is vállalhattak. A jelenlegi szabályozás értelmében a közfoglalkoztatással összekapcsolt szociális földprogramok megvalósítására csak azokon a településeken van mód, amelyek a Start-programokban nem érintettek.

A szociális földprogramok sikereit/kudarcait a tapasztalatok szerint két fó tényező határozza meg: az érintettek (vezetök és kedvezményezettek) aktivitása, valamint a program keretében megtermelt termékek piaci környezete (Biró és Székely et al., 2012). Sikeres szociális földprogramot föként olyan településeken müködtetnek, ahol az alapanyag-feldolgozók szükségleteit kielégítő élőmunkaigényes zöldség- és gyümölcstermesztéssel foglalkoznak, illetve ahol a tájjellegü terméket (savanyúság, lekvár, gyógynövény, konyhakerti vetőmagvak) helyben (iskola, szociális étkeztetés, turisztikai létesítmények) hasznosítják. 


\section{Munkanélküliek vállalkozóvá válásának támogatása}

A hazai költségvetésből finanszírozott aktív foglalkoztatáspolitikai eszközök közül mezőgazdasági tevékenység megkezdésére, folytatására is lehetőséget kínált a foglalkoztatás elősegítéséről és a munkanélküliek ellátásáról szóló törvény által 2007-ben bevezetett vállalkozóvá válást támogató $^{13}$ intézkedés, amelyet a járadékban részesülők és az álláskeresőként nyilvántartott személyek egyaránt igénybe vehettek. A tapasztalatok szerint - a piacok telítődése, a vállalkozói ismeretek, a termelés alapját jelentő földvagyon és a termesztéshez szükséges technológia és tudás hiánya miatt - a támogatási forma csak az álláskeresők szük csoportja számára jelentett tényleges alternatívát. A támogatáshoz éves szinten 3-7 ezer fő jutott hozzá, legnagyobb arányban az Észak-Alföldön és Dél-Dunántúlon. A támogatási forma - noha az aktív foglalkoztatáspolitikai eszközök közül az egyik legeredményesebb ${ }^{14}$ - jellemzően csak az önfoglalkoztatást biztosította, a létrehozott vállalkozások döntő hányada tartósan egyszemélyes maradt. Mezőgazdasági tartalmú vállalkozói tevékenység főként az agrárdominanciájú Dél-Alföldet jellemezte, ahol a nagyüzemek megszünését követően az önálló gazdálkodás jelentette a megélhetés egyik lehetséges útját. A piacon termékeikkel megjelenő, induló vállalkozások müködését a támogatási forma hatásait értékelő jelentések szerint főként a pénzügyi és marketingismeretek hiánya gátolta, az intézkedés hatékonyságát a fellépő holtteherhatás rontotta (Biró és Székely et al., 2012).

\section{Sorsforditó Program}

A „Sorsfordító - Sorsformáló” munkaerőpiaci program 2008-ban indult a Dél-dunántúli Regionális Munkaügyi Központ által meghirdetett regionális hatókörü komplex munkaerőpiaci programként (Kabai, 2011). A kétéves időtartamú program az induláskor Tolna megye hat településén müködött, később Somogy és Baranya megyére is kiterjedt, közel negyven települést érintve. A résztvevők - több mint 200 tartós munkanélküli - a program „sorsfordító” törekvései jegyében a zöldség- és gyümölcstermesztéshez kapcsolódó oktatásban részesültek, munkához jutottak, folyamatos személyiségi, életviteli mentorálás mellett. A munkalehetőségeket települési önkormányzatok, szövetkezetek és magángazdálkodók biztosították. A program „sorsformáló” részeként gyakornoki álláslehetőségek jöttek létre, amelyek keretében felsőfokú agrárvégzettségű pályakezdők (8 diplomás fiatal) három évre szóló bértámogatott munkalehetőséghez jutottak. A programban részt vevő önkormányzatok közül néhány (pl. Gyulaj) a mezőgazdasági termelést feldolgozással bővítette ki, amellyel jelentős forrásokat takarítanak meg, miközben folyamatosan munkát adnak lakosaiknak. A résztvevő települések többségében a mezőgazdasági tartalmú közfoglalkoztatási programokat a Sorsfordító Programban megkezdett helyi gazdaságfejlesztési kísérletek tapasztalataira alapozva indították el, illetve bővítették ki (Kabai és Németh, 2011).

\section{Háztáji program}

A 2012-2020 közötti időszakra szóló Nemzeti Vidékstratégia által megcélzott „termelésösztönzés" részeként 2013-ban indult el a háztáji program a Vidékfejlesztési Minisztérium, a Nemzeti Agrárgazdasági Kamara és a települési önkormányzatok együttmüködésére alapozva. A mintaprogramok finanszírozására a szaktárca az utóbbi években néhány száz millió forintot fordított. Egy-egy projekt megvalósítására esetenként 3,0-7,5 millió forint jutott. Jellemzően olyan települések (pl. a Szabolcs-Szatmár-Bereg megyei Rozsály) éltek a háztáji program elindításának lehetőségével, ahol a korábbi termelői hagyományokkal, illetve a szociális földprogrammal összefüggésben nagyobb esélye volt az önfenntartóvá válásnak. A program legsikeresebb elemének tekintett burgonyaprogram

\footnotetext{
13 A foglalkoztatás elősegítéséről és a munkanélküliek ellátásáról szóló törvény 17. §-a alapján támogatás nyújtható annak az álláskeresőnek (és rehabilitációs ellátásban részesülő személynek), aki munkaviszonyon kívüli tevékenységgel gondoskodik önmaga foglalkoztatásáról, ideértve azt is, aki vállalkozást indít vagy vállalkozáshoz csatlakozik. Támogatható az a személy is, aki önmaga foglalkoztatását egyéni vállalkozás keretében, gazdasági társaság - a társaság tevékenységében személyesen közremüködő - tagjaként, a személyi jövedelemadóról szóló 1995 . évi CXVII. törvény 3. §-a 18. pontjában meghatározott mezőgazdasági őstermelőként oldja meg. A támogatási összeg viszonylag magas, 6 hónapig a minimálbérnek megfelelő havi rendszeres juttatás, illetve legfeljebb hárommillió forint tőketámogatás (NFSZ, 2015).

14 A támogatásban részesülők közül munkába állók aránya 90 százalék körül mozog (Galasi és Nagy, 2012).
} 
keretében 100 ezer család részére juttattak vetőmagot, de sikeresnek mondható a kisállat- és haszonállatprogram is, amely 25 településen önkormányzati baromfitenyésztő telepek létrehozását eredményezte. A jószágok szaporulatát a programban résztvevő családokhoz helyezték ki, támogatták az állatférőhelyek kialakítását, biztosították az első évi takarmányt és a szükséges állategészségügyi szolgáltatásokat. A gyepre alapozott szarvasmarha- (magyar tarka) programba 35 családot vontak be, családonként 3 millió forint értékủ állomány kihelyezésével, valamint az első évi takarmány biztosításával.

A háztáji program keretében került meghirdetésre a használaton kívüli, elhanyagolt, felaprózott zártkerti gyümölcsösparcellák megvásárlását célzó Zártkert Revitalizációs Projekt, amelybe 15 önkormányzat kapcsolódott be. A helyi tájfajták termelésben tartását célzó programot már a Start-közfoglalkoztatási programokkal összehangolva valósították meg. A háztáji program részét képezi az „Alternatív támogatási rendszer”, amely fenntartható agroszociális mintaprogramokat (pl. szőlő, gyümölcsös, húsgalamb- és nyúltenyészetek, méhészet és gyógynövénytermesztés) támogat. A háztáji termékek piacra jutását a helyi piaclétesítés szabályainak liberalizálásával, valamint a helyi étkeztetésbe történő beszállítás lehetőségének kiterjesztésével igyekeztek megteremteni.

\section{Tanyafejlesztési program}

A Vidékfejlesztési Minisztérium által 2011-ben elindított, nemzeti forrásból finanszírozott Tanyafejlesztési Program ${ }^{15}$ vissza nem térítendő támogatás keretében nyújt segítséget a tanyán élőknek, köztük a kistermelőknek. A támogatási konstrukció alapvető célkitüzése a tanyai gazdálkodás sajátos értékeinek megmentése, a tanyarendszer megújítása, valamint a tanyán élők életszínvonalának, gazdálkodási feltételeinek javítása. A több mint 700 települést érintő programra hat alföldi megyéböl, illetve Pest megye déli járásaiból lehet pályázatot benyújtani.

A pályázati rendszer kétféle konstrukció keretében két célterületre irányulóan működött 2011-ben és 2012-ben. Az 1. célterület a települési és térségi fejlesztésekre, a 2. célterület a tanyagazdaságok fejlesztésére irányult. A program 2013-ban további két célterülettel bővült, ezek közül a 3. célterület a tanyagazdaságok elindítását célozta, a 4. célterület pedig a villany nélküli tanyák lakóépületének alapvető villamosenergia-ellátását biztosító egyéni fejlesztéseket támogatta. 2014-ben az alacsonyabb összegü forráskeret miatt csak a 2. és 4. célterületre lehetett pályázni, 2015-ben mind a négy célterület meghirdetésre került.

A 2011-2015 között eltelt időszakban a program keretében 1425 pályázat jutott összesen 7,36 milliárd forint értékü támogatáshoz. Az első három évben az 1. célterületre, ezen belül a tanyai termékek piacra jutásának elősegítésére jutott a források közel 80 százaléka, összesen mintegy 2,63 milliárd forint. A három év alatt közel félszáz településen került sor helyi termelői piac és tanyai termékeket értékesítö önkormányzati bolt építésére, felújítására. Az öt évet vizsgálva a tanyagazdaságok fejlesztésére 1,45 milliárd forint forrás jutott, amelyből mintegy 700 tanyagazdaságban valósultak meg a tanyai lakó- és gazdálkodási épületeket, gépeket érintő, állatállomány kialakítását célzó fejlesztések, átlagosan 2 millió forint támogatásból. Tanyagazdaságok indító támogatására 2013-tól lehetett pályázni, a három év alatt mintegy 147 tanyagazdaságot alapítottak átlagosan 2,4 millió forint támogatással.

Tekintettel arra, hogy a tanyák villany-, víz- és szennyvízberuházásaira a 2014-2020 közötti időszak Vidékfejlesztési Programja nyújt pályázati lehetőséget, a Tanyafejlesztési Program keretében 2016-tól három célterületre lehet pályázatot benyújtani. Az 1. célterület keretében a települési és térségi fejlesztések támogatására 200 millió forint áll rendelkezésre, amely a tanyasi termékek védjegy- és minőségrendszerének bevezetésére, fejlesztésére; a tanyagondnoki szolgálatok fejlesztésére; a tanyákon élők egészséges ivóvízzel történő ellátása érdekében szükséges vízminőség-

15 Tanyafejlesztési Program kereteit minden évben miniszteri rendelet szabályozza: 81/2011. (VIII. 11.) VM rendelet; 62/2012. (VI. 29.) VM rendelet; 56/2013. (VI. 29.) VM rendelet; 7/2014. (II. 6.) VM rendelet; 35/2015. (VI. 30.) FM rendelet; 30/2016. (IV. 29.) FM rendelet. 
vizsgálatok elvégzésére; a tanyán élőket célzó lakó- és vagyonbiztonsági rendszerek, valamint a biztonságot fokozó kommunikációs eszközök beszerzésére, telepítésére; továbbá a szigetüzemü külterületi közvilágítás kialakítására fordítható. A 2. célterületben a tanyagazdaságok indításának és fejlesztésének mezőgazdasági csekély összegü támogatására lehet pályázni, amelynek keretösszege 400 millió forint. A 3. célterület a tanyák lakóépületének felújítására, valamint lakó- és vagyonbiztonságot szolgáló egyéni fejlesztésekre irányul, melyre összességében 120 millió forint áll rendelkezésre.

\section{Civil kezdeményezések}

\section{„Minden gyerek lakjon jól” Alapítvány}

A „Minden gyerek lakjon jól” Alapítvány vetőmagcsomagokkal, aprójószágok kihelyezésével támogatja a mélyszegénységben élőket. Az ehhez szükséges forrásokat túlnyomórészt magántőke biztosítja. Az alapítvány 2011-2014 között 617 településen 36266 családnak biztosított egy évre szóló vetőmagcsomagot, családonként mintegy 200 négyzetméter nagyságú kert beültetéséhez. Állatkihelyezéssel 2011-től foglalkoznak, közel 1 millió naposcsibét, 200 ezer naposkacsát, 150 ezer tyúkot, 3 ezer nyulat és 811 malacot osztottak szét a rászoruló családok körében. A családok felkutatásában a települési önkormányzatok és a cigány kisebbségi önkormányzatok müködnek közre. A kihelyezett jószág mellé takarmányt, alapvető eszközöket és szakmai segítséget is nyújtanak.

\section{Kiút Program}

A Grameen-modell alapján magánszemélyek kezdeményezésére 2009-ben elindított Kiút Program a mélyszegénységben élöket önfoglalkoztató vállalkozások elindításához nyújtott mikrohitelekkel támogatja 1 millió forint összeghatárig. A magánkezdeményezésre indult program az üzleti élet meghatározó szereplőinek támogatása mellett uniós támogatásokat ${ }^{16}$ is mozgósított, illetve 2012-ig kormányzati kiegészítő támogatásban részesült.

A program területi hatóköre Borsod-Abaúj-Zemplén és Szabolcs-Szatmár-Bereg megye leghátrányosabb helyzetü településeire, illetve a főváros VIII. kerületére korlátozódik. A terepen tevékenykedő, a Kiút Program alkalmazásában álló mentorok nemcsak a vállalkozások létrehozását segítik, hanem közösségfejlesztő, hálózatszervező tevékenységet is folytatnak. A program kiemelt hangsúlyt helyez a résztvevő családok képzésére, a folyamatos szakmai, életviteli tanácsadásra.

A Kiút Program egyik legsikeresebb kezdeményezése a Szabolcs-Szatmár-Bereg megyében elindított együttmüködés, amelynek keretében közel 100 szatmári (szatmárcsekei, kántorjánosi) roma családot vontak be az uborkatermesztő tevékenységbe. A programkoordinátorok piaci szereplöket is mozgósítottak, például a friss zöldség és gyümölcs iránt keresletet mutató Tyukodi Konzervgyárat. A feldolgozóüzem biztosítja a termeléshez szükséges szakmai ismereteket, palántát, permetezőszereket, továbbá az ügyfelekkel kötött egyéni megállapodás alapján felvásárolja az uborkát. Az eddigi tapasztalatok szerint a programból való lemorzsolódás minimális, a családok többsége több éve részt vesz az integrált termelésben. A termelésből származó bevétel a kisebb területeken is (300 folyóméter) fedezte a termelési költségeket, a nagyobb területeken a bevétel 50 százaléka nyereségként realizálódott. A program piaci beágyazottságát mutatja, hogy a termelésben nemcsak az ügyfelek, illetve családtagjaik vettek részt, hanem a nagyobb területeken gazdálkodóknál napszámosokat, idénymunkásokat is alkalmaztak.

Az eddigi eredményeket összegezve a Kiút Programban az egy ügyfélre jutó éves költség a jelentős hitelezési veszteségek ellenére megegyezik egy személy közfoglalkoztatásának éves költségeivel, a szociális mikrohitelezés hatékonysága azonban meghaladja a közfoglalkoztatás hatékonyságát. Járulékos hatás a kedvezményezettek adófizetővé válása, a szociális kiadások csökkenése, valamint a feketegazdaság mérséklödése. A Kiút Program keretében 2009-2012 között közel 150 mélysze-

\footnotetext{
16 Pan-European Coordination of Roma Integration Methods - Roma inclusion: self-employment and microcredit (2010-2012, 1425 millió euró).
} 
génységben élő ügyfél vett fel fedezet nélküli hitelt vállalkozása elindításához. Közülük 73 fő egyéni vállalkozóvá vált, 63 fő őstermelői engedélyt váltott ki. Az elsőként kihelyezett hitelekből indított vállalkozások (41 fö) 30 százaléka (13 fő) jelenleg is müködik. Várhatóan legalább az ügyfelek fele esetében hosszabb távon fenntartható vállalkozások jönnek létre (Molnár et al., 2012).

\section{„Nyúl-unk a munkáért” program}

A nyúltenyésztés elterjesztését célzó „Nyúl-unk a munkáért” program indulása óta több mint 200 családot kapcsolt be a kisüzemi nyúltartásba. A Mágocs mellett elhelyezkedő, családi vállalkozásként induló, mára Magyarország egyik legnagyobb nyúlintegrátorává váló Anas Szövetkezet, illetve a hazai nyúltenyésztők által létrehozott Zika Nyúltenyésztő és Forgalmazó Szövetkezet által kezdeményezett program keretében a rászoruló családokhoz szülőpárt (anyanyulat, bakot), háromhavi takarmányt, technológiát (nyúlketrec) helyeznek ki. A kihelyezés feltétele településenként legalább 10-15 aktív termelö jelenléte.

Eddig összességében 55-60 falu kapcsolódott be a programba, jellemzően Baranya, Tolna és Somogy megye települései. A magánkezdeményezéshez a későbbiekben több piaci szereplő is csatlakozott, de kiegészítő forrásokkal segítette a kezdeményezést a Földmüvelésügyi Minisztérium és az Emberi Erőforrások Minisztériuma is. A kezdeményezés szakmai vezetőjével készített interjú szerint a program eredményeként kialakult egy piaci árutermelésre képes kistermelői kör, amely a koordinált termelés és értékesítés eredményeként rendszeres jövedelemhez jut.

\section{A fejlesztéspolitikai eszközök értékelése}

A mezőgazdasági tartalmú programokat értékelve általánosságban elmondható, hogy munkaerőpiaci reintegráló hatásuk csak mérsékelt, a jövedelemszint emeléséhez, a tudástőke és a kapcsolatrendszer valamilyen szintủ gyarapításához azonban kivétel nélkül hozzájárulnak. A megvalósított programok közül föként a kisméretü, más eszközökkel kombinált kezdeményezések hatásosak (37. táblázat).

Fenntartható eredmények elsősorban azokban a programokban mutatkoznak, amelyekbe piaci szereplöket is bevontak, illetve amelyekben kialakult egy a helyi közösség számára hiteles, a szervezési, animálási tevékenységeket ellátó menedzsment, amely lehetőség szerint újratermeli a továbbmüködtetéshez szükséges pénzügyi forrásokat (Czene et al., 2010). Járulékos hatások - a résztvevők adófizetőkké válása, a települési szintü szociális kiadások mérséklése, a feketegazdaság csökkenése - azokban a programokban jelentkeznek, ahol a termelési erőforrásokhoz, valamint a piacokhoz való hozzáférés lehetőségei megteremtődnek. 


\section{7. táblázat: A mezőgazdasági tartalmú szociálpolitikai és munkaerő-piaci programok} főbb jellemzői

\begin{tabular}{|c|c|c|c|c|}
\hline Megnevezése & Kezdete & Területi hatóköre & Forrása & Eredmények, föbb hatások \\
\hline $\begin{array}{l}\text { Szociális } \\
\text { földprogram }\end{array}$ & 1992 & $\begin{array}{l}\text { leghátrányosabb } \\
\text { helyzetü } \\
\text { települések }\end{array}$ & $\begin{array}{l}\text { kormányzati } \\
\text { támogatás }\end{array}$ & $\begin{array}{l}\text { szezonálisan jelentkező kiegészítő jö- } \\
\text { vedelmek; a mezőgazdasági termelés- } \\
\text { ben közvetlenül hasznosítható szaktu- } \\
\text { dás és tapasztalat felhalmozása }\end{array}$ \\
\hline $\begin{array}{l}\text { Vállalkozóvá } \\
\text { válás támogatása }\end{array}$ & 2007 & országos & $\begin{array}{l}\text { kormányzati } \\
\text { támogatás }\end{array}$ & $\begin{array}{l}\text { önfoglalkoztatóvá válás } \\
\text { (90 százalékban) }\end{array}$ \\
\hline $\begin{array}{l}\text { Sorsfordító } \\
\text { program }\end{array}$ & 2008 & Dél-Dunántúl régió & $\begin{array}{l}\text { kormányzati } \\
\text { támogatás }\end{array}$ & $\begin{array}{l}\text { átmeneti foglalkoztatási lehetőség; a } \\
\text { mezőgazdasági termelésben közvetle- } \\
\text { nül hasznosítható szaktudás és tapasz- } \\
\text { talat felhalmozása }\end{array}$ \\
\hline Háztáji program & 2013 & országos & $\begin{array}{l}\text { kormányzati } \\
\text { támogatás }\end{array}$ & $\begin{array}{l}\text { hozzájárulás a háztartási fogyasztási } \\
\text { szükségletek kielégítéséhez }\end{array}$ \\
\hline $\begin{array}{l}\text { „Minden gyerek } \\
\text { lakjon jól” } \\
\text { Alapítvány }\end{array}$ & 2011 & országos & $\begin{array}{l}\text { magántőke; } \\
\text { kiegészítő } \\
\text { kormányzati } \\
\text { támogatás }\end{array}$ & $\begin{array}{l}\text { hozzájárulás a háztartási fogyasztási } \\
\text { szükségletek kielégítéséhez }\end{array}$ \\
\hline Kiút Program & 2009 & $\begin{array}{l}\text { Borsod-Abaúj- } \\
\text { Zemplén, } \\
\text { Szabolcs- } \\
\text { Szatmár-Bereg } \\
\text { megye, } \\
\text { Budapest }\end{array}$ & $\begin{array}{l}\text { magántőke; } \\
\text { uniós támogatás; } \\
\text { kiegészítő } \\
\text { kormányzati } \\
\text { támogatás }\end{array}$ & $\begin{array}{l}\text { az ügyfelek fele esetében hosszabb } \\
\text { távon fenntartható vállalkozások létre- } \\
\text { jötte }\end{array}$ \\
\hline $\begin{array}{l}\text { „Nyúl-unk } \\
\text { a munkáért" } \\
\text { program }\end{array}$ & 2011 & $\begin{array}{l}\text { Baranya, Tolna, } \\
\text { Somogy megye }\end{array}$ & $\begin{array}{l}\text { magántőke; } \\
\text { kiegészítő } \\
\text { kormányzati } \\
\text { támogatás }\end{array}$ & $\begin{array}{l}\text { piaci árutermelésre képes kistermelői } \\
\text { hálózat kiépülése }\end{array}$ \\
\hline
\end{tabular}

Forrás: Az AKI Vidékfejlesztési Kutatási Osztályán készített összeállítás 


\section{Az árutermelő gazdasággá alakítható kisüzemek számának becslése}

A fejezetben az árutermelővé alakítható gazdaságkör becslésére vállalkozunk, azt vizsgálva, hogy milyen háttérrel válik valószínűvé a gazdaságvezető döntése az árutermelés folytatása mellett, illetve hogy milyen nagyságrendben várható az árutermelővé váló gazdaságok megjelenése 2020-ig.

\section{A mezőgazdasági üzemek tipizálása a különböző üzemdefiníciók alapján}

A korábbi fejezetekben bemutatásra került a mezőgazdasági kisüzemek mezőgazdaságban betöltött súlya, gazdálkodásának körülményei, szociológiai háttere, alapvetően az ÁMÖ 2010-re alapozva, valamint költség-jövedelem viszonyai a tesztüzemi rendszer 2013. évi adatgyüjtése alapján. Ha az ÁMÖ és a tesztüzemi adatok alapján nyert információkat el kívánjuk helyezni a módszertani fejezetben bemutatott ábrán, a következő, a szociológiai és gazdálkodási viszonyokat is magában foglaló ábra készíthető el (11. ábra).

11. ábra: Az üzemek jellegzetességei ökonómiai méret és fóbb jellemzők szerint

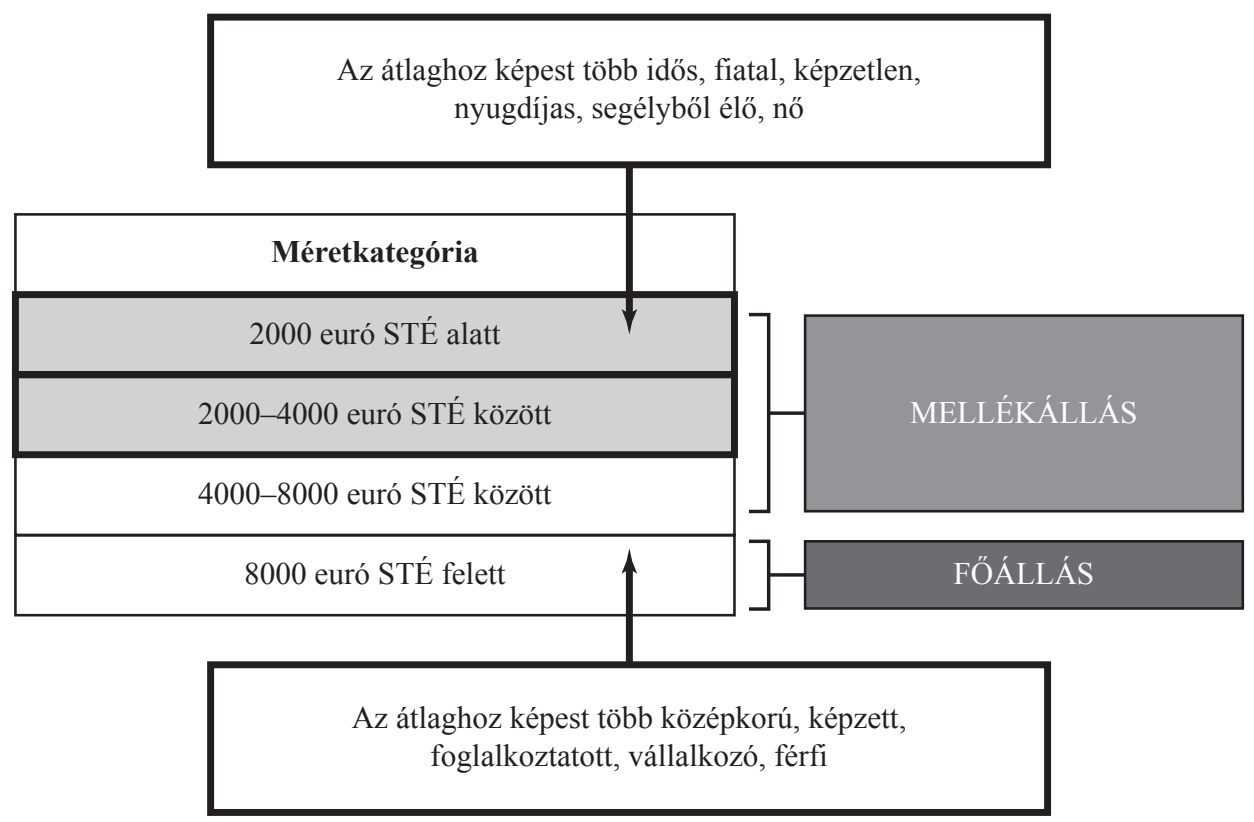

Forrás: ÁMÖ alapján AKI, 2016

Ha tipizálni akarjuk a termelőket, a következő csoportokat állíthatjuk fel a 11. ábra termelői sokaságán belül:

- A 2000 euró STÉ alatti kisüzemek (1. téglalap) esetében a termelési érték olyan kis léptékü, hogy a háztartás gond nélkül el tudja fogyasztani a tavaszi-nyári, illetve őszi hónapokban megtermelt terményt - ha máshogy nem, tartósítva, pincében tárolva. A mezőgazdasági tevékenység jövedelempótló szerepe e termelöi csoport esetében viszonylag csekély.

- A 2000-4000 STÉ euró közötti kisgazdaságok (2. téglalap) körébe tartoznak azon vidéki háztartások, amelyek nagy belső kertjükön vagy egy-két hektár földjükön gazdálkodnak és 
a normál jövedelemszerző tevékenység vagy nyugdíj mellett, azt kiegészítve mezőgazdasági termelést is végeznek. A nagyobb volumenü termelés melletti saját fogyasztást részben az állattartás teszi lehetővé, amelynek termékei a napi fogyasztásban felhasználhatók, és ami által az évente egyszer betakarított szántóföldi termény egész évben felhasználható. A 2000-4000 euró STÉ közötti csoportba sorolhatók a kis konyhakertnél nagyobb területen gazdálkodó, jellemzően szántóföldi növénytermesztést, ültetvényes gazdálkodást vagy kertészkedést folytató üzemek is. Az általuk megtermelt termékek jellemzően nem alkalmasak közvetlen fogyasztásra, illetve nem eltarthatók, ezért az értékesítés gyakorlatilag kényszerként jelentkezik. A gazdálkodási tevékenység jövedelempótló szerepe nem elhanyagolható.

- A 4000-8000 euró STÉ közötti gazdaságok (3. téglalap) legfeljebb félállású foglalkoztatást kínálnak, körükben egyszerre találunk növénytermesztő árutermelő gazdaságokat, illetve a termékfeleslegükkel a piacon rendszeresen megjelenő, a család élelmiszer-szükségletét is kiszolgáló tehén-, kecske-, baromfi- vagy sertéstartó gazdaságokat. A tevékenység jövedelempótló szerepe jelentős.

- A 8000 euró STÉ feletti árutermelő gazdaságok (4. téglalap) körébe jellemzően a főfoglalkozású árutermelők tartoznak, amelyek gazdasága gyakorta a saját fogyasztás céljait is kiszolgálja. A mezőgazdasági tevékenység elsődleges jövedelmet biztosít.

A fenti tipizálás alapján elmondható, hogy a fejlesztéspolitika két érdemi és összekapcsolható célt tűzhet maga elé: egyrészt a 4000 euró STÉ alatti üzemek elmozdítását a piaci értékesítés irányába, másrészt a melléktevékenységként végzett gazdálkodás föállássá tételét, amelyhez az üzemeket el kell juttatni a 8000 euró STÉ feletti termelési értékig.

\section{Kisüzemek típusai klaszterelemzés alapján}

Az árutermelővé alakítható gazdaságok nagyságának becslése céljából a 2013. évi reprezentatív tesztüzemi adatbázis felhasználásával klaszterelemzést végeztünk. Az üzemcsoportok azonosítására SPSS programcsomag alkalmazásával, K-Means Cluster módszerrel került sor.

A klaszterképzésnél a változók közötti összefüggések erősségének vizsgálatát követően három változót vettünk figyelembe: a gazdaság teljesítményét kifejező, hektárra vetített adózás előtti eredményt; a mezőgazdasági tevékenységet végző háztartás jövedelemtípusainak számát; valamint egy, a humántőke-ellátottságról képet adó komplex mutatót, amelyet három alapváltozó (gazdaságvezető születési éve, képzettsége, valamint a családtagok száma) aggregálásával, faktoranalízissel képeztünk (11. melléklet).

A fenti változók alapján a klaszterelemzés során a kisüzemek három csoportját (piacra termelő kisüzemek, kiegészítő jellegủ árutermelő kisüzemek, háztartásgazdaságok) azonosítottuk 239 üzem típusokba rendezésével ${ }^{17}$ (12. melléklet). A három klasztercsoportba sorolt üzemek főbb szociodemográfiai paramétereit, illetve gazdálkodási jellemzőit, pénzügyi teljesítményét kifejező mutatókat a 38. táblázatban foglaltuk össze.

- A klaszterképzésnél figyelembe vett gazdaságok bő 40 százalékát (98 db) kitevő „,piacra termelö kisüzemek" az átlagnál (180 ezer forint/hektár) jóval nagyobb adózás elötti eredménnyel rendelkeznek és humántőke-ellátottságuk is kedvezőbb a többi üzemcsoportba sorolt gazdaságénál. A három klasztercsoport közül ebben a gazdaságvezetői körben a legalacsonyabb az átlagéletkor (49 év), a legmagasabb a felsőfokú végzettséggel rendelkezők aránya (29,6 százalék) és itt a legnagyobb a gazdaságba munkaerőként bevonható családlétszám (3,5 fö). A csoportba sorolt üzemek annyi árualapot állítanak elö, amely lehetővé teszi folyamatos piaci jelenlétüket. Ezt jelzi hektárra vetített adózás előtti eredményük, ami majdnem kétszerese a mintaátlagnak és hatszorosa (325,5 ezer forint) a zömmel saját fogyasztásra termelö „,háztartásgazdaságokénak”. A csoportba sorolt üzemek árutermelő orientációját jelzi, hogy

${ }^{7}$ A klaszterelemzés során adathiány miatt 62 üzem nem került be a vizsgálatba. 
a mezőgazdasági tevékenységből származó éves jövedelmük az összes jövedelem csaknem harmadát (27,4 százalék) teszi ki, miközben a saját fogyasztásra termelés aránya mindössze 6,5 százalék. Túlnyomó részük ( 57,1 százalék) növénytermesztéssel foglalkozó gazdaság, de a mintaátlagot meghaladó körükben az állattenyésztő üzemek aránya (21,4 százalék) is. Ezen gazdaságok a gazdálkodásból származó jövedelem mellett egyéb bérjellegü jövedelemforrással is rendelkeznek, ami gazdaságuk fejlesztésére, bővítésére kínál többletlehetőséget.

- A kisüzemek szűkebb csoportja (30 db) olyan ,,kiegészitő jellegü árutermelő gazdaságként” azonosítható, amelynek adózás előtti eredménye csak fele a „piacra termelő” kisgazdaságokénak (166,8 ezer forint/hektár), a túlnyomórészt növénytermesztésre (73,3 százalék) alapozott mezőgazdasági tevékenységük azonban egyértelmúen árutermelésre irányul. Ezt jelzi a saját fogyasztásra termelés teljes jövedelemhez viszonyított alacsony (5,2 százalék) aránya. A mezőgazdasági tevékenység jövedelemtermelésben betöltött szerepe ugyan elmarad az előző csoportétól, a háztartás összes jövedelmének azonban így is közel ötödét (17,0 százalék) teszi ki. Az átlagnál magasabb jövedelemszinttel jellemezhető gazdaságok humántőke-ellátottsága az előző klasztercsoport tagjainál kedvezőtlenebb: a gazdaságvezetők átlagéletkora 50 év, ,csak” 20 százalékuk rendelkezik felsőfokú iskolai végzettséggel és a háztartás létszáma is elmarad az első csoportba tartozó kisüzemekétől (2,7 fö). Noha a kisüzemek ezen csoportjában rendelkezésre áll a jövedelmezőbb gazdálkodáshoz szükséges humán tőke, a mezőgazdasági tevékenység bővítése nem jelenik meg célként a többi üzemcsoporthoz képest diverzebb és az átlagnál magasabb bevételeket ( 3 millió forint/év) biztosító jövedelemszerkezettel, illetve a gazdaságon kívül lekötött munkaerővel összefüggésben.

- A gazdaságok majdnem fele (46 százalék) olyan „háztartásgazdaság” (111 db), amely az átlagnál alacsonyabb jövedelmezőséggel gazdálkodik (adózás előtti eredményük mindöszsze 56,2 ezer forint/hektár), jövedelemszerkezetében a nyugdíjak, illetve az egyéb szociális jövedelemtípusok dominálnak. A csoportba sorolt üzemek humántőke-ellátottsága átlag alatti: a gazdaságvezetők átlagéletkora bő tíz évvel haladja meg az árutermelő kisgazdaságokét és ebben az üzemcsoportban a legmagasabb (29,7 százalék) a csak alapfokú végzettséggel rendelkező üzemvezetők aránya. (A „háztartásgazdaságokat” vezetők körében egyetlen olyan üzemvezető sincs, akinek felsőfokú végzettsége volna). A „háztartásgazdaságokban” a mezőgazdasági tevékenység a megélhetéshez nyújt fedezetet. Ezt jelzi a mezőgazdasági tevékenységből származó jövedelem közel 70 százalékos (68,1 százalék) és a saját fogyasztásra termelés közel 20 százalékos (17,2 százalék) aránya. A saját fogyasztási szükségleteket kielégítő funkcióval összefüggésben ebben az üzemcsoportban a legnagyobb (30,6 százalék) a háztartás élelmiszer-szükségletéhez illesztett ,vegyes” termelési profil. Az üzemcsoportba sorolt gazdaságok földterületének átlagos mérete (3,8 hektár) ugyan nem marad el jelentősen a többi klasztercsoportba sorolt üzemétől, a gazdaságba munkaerőként bevonható családtagok alacsonyabb létszáma (1,7 fó), valamint a gazdaságvezető magasabb átlagéletkora (61 év), tudástőkéjének hiánya fejlesztési korlátként jelentkezik. 
38. táblázat: A kisüzemi klasztercsoportok főbb jellemzői

\begin{tabular}{|c|c|c|c|c|}
\hline \multirow[b]{2}{*}{ Jellemzők } & \multicolumn{3}{|c|}{ Típusok } & \multirow[b]{2}{*}{$\begin{array}{l}\text { Minta- } \\
\text { átlag }\end{array}$} \\
\hline & $\begin{array}{l}\text { „Piacra termelő } \\
\text { kisüzemek” } \\
\text { (98 darab) }\end{array}$ & $\begin{array}{c}\text { „Kiegészítő jellegü } \\
\text { árutermelő } \\
\text { kisüzemek” } \\
\text { (30 darab) }\end{array}$ & $\begin{array}{c}\text { „Háztartás- } \\
\text { gazdaságok” } \\
\text { (111 darab) }\end{array}$ & \\
\hline Gazdaságvezető életkora, év & 49 & 50 & 61 & 55 \\
\hline $\begin{array}{l}\text { Gazdaságvezető iskolai } \\
\text { végzettsége, százalék }\end{array}$ & magasabb szintü & magasabb szintü & átlag alatti & - \\
\hline - alapfok & 0 & 13,3 & 29,7 & 15,5 \\
\hline - középfok & 70,4 & 66,7 & 70,3 & 69,9 \\
\hline - felsőfok & 29,6 & 20,0 & 0 & 14,6 \\
\hline Családlétszám, fő & 3,5 & 2,7 & 1,7 & 2,6 \\
\hline Adózás elött eredmény, forint/hektár & 325,6 & 166,8 & 56,2 & 180,6 \\
\hline Jövedelemtípusok száma, darab & 2,9 & 3,1 & 3,3 & 3,1 \\
\hline $\begin{array}{l}\text { Mezőgazdaságból származó } \\
\text { jövedelem aránya az összes } \\
\text { jövedelemből, százalék }\end{array}$ & 27,4 & 17,0 & 68,1 & 45,0 \\
\hline $\begin{array}{l}\text { Saját fogyasztásra termelés aránya } \\
\text { az összes jövedelemböl, százalék }\end{array}$ & 6,5 & 5,2 & 17,2 & 11,1 \\
\hline Éves munkaerőegység (ÉME) & 0,37 & 0,36 & 0,29 & 0,33 \\
\hline Használt mezőgazdasági terület, ha & 4,0 & 3,9 & 3,8 & 3,9 \\
\hline Ágazat, százalék & $\begin{array}{c}\text { zömmel } \\
\text { növénytermesztő }\end{array}$ & $\begin{array}{c}\text { zömmel } \\
\text { növénytermesztő }\end{array}$ & vegyes & - \\
\hline - növénytermesztő & 57,1 & 73,3 & 48,6 & 55.2 \\
\hline - állattenyésztő & 21,4 & 13,3 & 20,7 & 20,1 \\
\hline - vegyes & 21,4 & 13,3 & 30,6 & 24,7 \\
\hline Teljes jövedelem, ezer forint & 2623,4 & 3004,7 & 1635,5 & 2212,4 \\
\hline
\end{tabular}

Forrás: AKI, 2016

A tesztüzemi mintán elvégzett klaszterelemzés alátámasztotta, hogy a hazai mezőgazdasági kisüzemek termelési funkcióik, szociodemográfiai jellemzőik, pénzügyi, gazdasági teljesítményük alapján különböző csoportokra tagolódnak. A klaszterképzéssel lehatárolt üzemcsoportok közül a mezőgazdasági tevékenység bővítése elsődlegesen az aktív korú gazdaságvezetők által irányított „piacra termelő kisüzemekben” merül fel, amelyek magasabb humántőke-ellátottságuk, már meglévő piaci kapcsolataik, munkaerő-tartalékaik folytán nagyobb eséllyel fejleszthetők tovább akár fötevékenységü árutermelö üzemekké. A jövedelmüket más ágazatban végzett munka mellett gazdálkodással bővíto „kiegészítő kisüzemekben” fejlesztési potenciál főként a piaci alkupozíciót és az információkhoz való hozzáférést javító integráció erősítésében rejlik, míg a „háztartásgazdaságokban" az alacsony humántőke-ellátottsággal összefüggésben a tudástőke (akár szaktanácsadás formájában történő) bővítése, valamint a piacra jutást REL-típusú együttműködésekkel segítő hálózatok kiterjesztése járulhat hozzá a teljesítményjavuláshoz. 


\section{Az árutermelő gazdasággá alakítható kisüzemi kör becslése a szociológiai háttér alapján}

Logikai alapon a hazai, 4000 euró STÉ alatti méretű kisüzemi körből azon termelők válhatnak leginkább árutermelővé, amelyek rendelkeznek a következő képességekkel:

- kellően fiatalok ahhoz, hogy hajlandóak legyenek a váltásra;

- legyen tapasztalatuk az áru értékesítését illetően, tehát legalább részben árutermelő gazdaságokat vezessenek;

- legyen legalább alapfokú végzettségük, ami alapot ad a minimális üzemvezetői ismeretek megszerzésére.

Ennek megfelelően a már jelenleg is piaci szerepvállalással jellemezhető fiatalabb korosztályok esetében az árutermelővé válás esélye nagyobb, nem függetlenül attól, hogy az idősebb gazdaságvezetők mezőgazdaságból történő kilépése további birtokkoncentrációt és nem új belépéseket eredményez. Az adatokat STÉ, termelési cél és életkor szerint vizsgálva a 4000 euró STÉ alatti, félig önellátó egyéni gazdaságok közül összességében mintegy 17,1 ezer 44 évesnél fiatalabb gazdaságvezető által irányított üzem (az összes regisztrált egyéni gazdaság 3 százaléka) képezi az árutermelésbe potenciálisan bevonható gazdaságok körét.

Az STÉ, a termelési cél, valamint a szakképzettség együttes figyelembevétele alapján a 4000 euró STÉ alatti méretkategóriába tartozó, félig önellátó gazdaságvezetők közül föként az a 9,7 ezer gazdaság válhat piaci árutermelővé, amelynek vezetője legalább alap- vagy középszintü $(8,2$ ezer gazdaság), illetve felsőfokú szakképzettséggel (1,5 ezer gazdaság) rendelkezik (8. melléklet).

Bár az árutermelővé válás a gazdasági aktivitás szerint elkülönített csoportok egyikénél sem kizárt - ezt támasztja alá, hogy a munkanélküli gazdaságvezetők által müködtetett üzemek körében is előfordulnak árutermelők -, a tevékenység forgótőkeigénye miatt főként olyan üzemek esetében van reális esélye, amelyek a gazdaságba forgatható rendszeres jövedelemmel rendelkeznek. Másfelöl azonban az alternatív jövedelemszerző tevékenység akadályt is jelenthet az árutermelővé válásban, mivel csökkenti a mezőgazdasági jövedelem elérésére fordítható munkaidőt - különösen, ha fóállásban foglalkoztatott termelőről beszélünk, aki csupán kisegítő tevékenységként folytat mezőgazdasági termelést.

Összességében az egyéni gazdaságok szociodemográfiai jellemzőinek részletes áttekintése alapján a piaci árutermelésbe bevonható üzemek köre a következőképpen alakul, ha elemzésünkben az egyes szociodemográfiai változók közül a gazdaságvezetők életkorát és szakképzettségét vesszük alapul. A két változót együttesen figyelembe véve a 4000 euró STÉ alatti méretkategóriában mintegy 10750 olyan, humán tőkével az átlagnál jobban ellátott (legalább alap- vagy középfokú képzettségű), 44 évesnél fiatalabb gazdaságvezető azonosítható, aki nagy eséllyel árutermelővé válhat (39. táblázat). Jól látható, hogy a kiválasztott gazdaságtípus nem a 4000 euró STÉ alatti gazdaságokra jellemző tipikus tulajdonságokkal rendelkezik, inkább az e gazdaságkörben megjelenő kivételeket veszi célba. 
39. táblázat: Potenciálisan árutermelővé alakítható (4000 euró STÉ alatti) kisüzemek

\begin{tabular}{|c|c|c|c|c|}
\hline \multicolumn{5}{|c|}{ Alap- vagy középszintű végzettségú } \\
\hline STÉ-méretkategória & 25 év alatti & 25-34 éves & 35-44 éves & Összes \\
\hline 2000 euró STÉ alatt & 259 & 1943 & 4252 & 6454 \\
\hline 2000-4000 euró STÉ & 104 & 741 & 1803 & 2648 \\
\hline \multicolumn{5}{|c|}{ Felsőfokú végzettségü } \\
\hline & 25 év alatti & 25-34 éves & 35-44 éves & Összes \\
\hline 2000 euró STÉ alatt & 35 & 472 & 691 & 1198 \\
\hline 2000-4000 euró STÉ & 11 & 172 & 267 & 450 \\
\hline \multicolumn{5}{|c|}{ Összes } \\
\hline & 25 év alatti & 25-34 éves & 35-44 éves & Összes \\
\hline 2000 euró STÉ alatt & 294 & 2415 & 4943 & 7652 \\
\hline 2000-4000 euró STÉ & 115 & 913 & 2070 & 3098 \\
\hline Összes & 409 & 3328 & 7013 & 10750 \\
\hline
\end{tabular}

Forrás: ÁMÖ 2010 alapján AKI Vidékfejlesztési Kutatási Osztály

\section{Az árutermelő gazdasággá alakítható kisüzemi kör becslése az egyéb jövedelemszerző tevékenység alapján}

A kisüzemek költség-jövedelem viszonyait bemutató fejezetben, az egyéb jövedelemszerző tevékenység alapján csoportosított tesztüzemi minta vizsgálatakor három jól elkülöníthető típus jelent meg: az önfoglalkoztató vállalkozók és a mezőgazdasági alkalmazottak csoportja, valamint a többiek (nem mezőgazdasági alkalmazottak, nyugdíjasok, szociális transzferből élők).

A mezőgazdasági alkalmazottak esetében egyértelmüen hobbitevékenységről (még ha igen nagy volumenü is ez a tevékenység) beszélhetünk, ahol nem a közgazdasági racionalitás, hanem a saját termény, a saját tevékenység elvégzése a döntő.

A másik két kategóriát összevetve, a vállalkozók esetében egyértelmű, hogy bár kis területen gazdálkodnak, alapvetően az adózás előtti eredmény maximalizálása a céljuk minél hatékonyabb eszköz- és munkaerő-lekötéssel, ennek megfelelően nagyfokú a specializáció, minimális a saját fogyasztás, igen jelentős értékesítési tevékenységet folytatnak és magas eszközértékkel, valamint magas költségráfordítással rendelkeznek. A másik kategóriában - bár az értékesítés aránya még akár magasabb is lehet, mint a vállalkozóknál - közel sem ilyen „racionális” a gazdálkodás. Jóval kisebb az eszközlekötés, a ráfordítás, amely nagyjából ugyanolyan munkaerő-lekötéssel jár együtt, mint a vállalkozóknál. Ennek oka, hogy ebben a csoportban nem a maximális, munkaerőre is érvényesített hatékonyság, hanem a megtermelt és így elfogyasztható vagy értékesíthető árualap növelése a cél, lehetőleg limitált mennyiségü vásárolt anyag és eszköz, illetve minél több üzemben megtermelt anyag és belső munkaerő felhasználásával.

Jól látható, hogy ebben a kategóriában az alkalmazottak és a nyugdíjasok esetében a bruttó kibocsátás és az üzemi összjövedelem növelése érdekében még van mozgástér a ráfordításnövelésre, a szociális transzferből élőknél azonban már nincsen erre mód, így ezen üzemcsoport rendelkezik a legkisebb anyagi ráfordításokkal, a legkisebb eszközértékkel, ebből következően a legkisebb hektáronkénti bruttó termelési értékkel. Összességében azonban ez utóbbi csoportról is elmondható, hogy érdemi jövedelemjavulást ér el viszonylag elfogadható éves munkaerőegységre jutó felhasználható jövedelemmel. 
E csoportok közül az alapvetően vállalkozói szemléletet igénylő, profitmaximalizáló árutermelővé válásra leginkább az önfoglalkoztató üzemvezetők képesek, mivel az alapvetően elsajátítandó készség már birtokukban van. Ráadásul ez a réteg már eddig is bizonyította, hogy képes hozzáférni a KAP támogatásaihoz, nem csupán a területalapú támogatásokhoz, hanem más támogatási formákhoz is, emellett a képzettsége is megfelelő (legalább középfokú) és az életkora is kedvező (40 év körüli átlaggal).

Az egyéb csoportokat tekintve a nyugdíjasoktól életkorukból fakadóan nem várható el, hogy mezőgazdasági tevékenységüket fokozzák és növeljék árualapjukat. Érvényes ez a szociális juttatásból élőkre is, mivel egyrészt viszonylag idősek, másrészt ők a legkevésbé piaci szemléletü, leginkább saját fogyasztásra termelő réteg, amely ráadásul a legkevesebb eszközzel rendelkezik, így nekik lenne szükségük a legnagyobb beruházásokra.

A mezőgazdasági alkalmazottak esetében teljes elvi fordulatra lenne szükség, hogy „hobbi” helyett „megélhetésként” tekintsenek a kiegészítő mezőgazdasági tevékenységre, ráadásul mivel nekik van a legmagasabb jövedelmük, nem valószínü, hogy a magas lehetőségköltség okán több munkaidőt áldoznának egy bizonytalan és eddig igen szolid jövedelmet hozó tevékenységre.

A nem mezőgazdasági alkalmazottaknál az életkor és a képzettség érdemi alapot jelentene, és itt a jövedelemszerző attitűd is dominál, viszont felmerül a munkában eltöltött idő után járó jövedelem és a mezőgazdaságban szerzett jövedelem viszonya. Ha ezen alkalmazotti réteg munkajövedelmét elosztjuk az ilyen háztartásokban élő aktív korúak számával, közel ugyanakkora összeget, 1,1 millió forint nettó bért kapunk, mint a mezögazdasági munkavégzésre jutó jövedelem éves értéke. Tehát ha csak az eddigi színvonalon végezné az alkalmazott a mezőgazdasági termelést, nagyobb munka-, tőke- és földlekötéssel, ugyanakkora jövedelemhez juthatna, mint az aktuális föállásával. Ez azonban egyrészt bizonytalanabb lenne, mint az alkalmazotti jövedelem, másrészt igen jelentős beruházásokat (földvásárlás, eszközbeszerzés, piacszerzés) és többlet-erőfeszítést igényelne. Ezek után nem kétséges, hogy ebből a csoportból csak azok vágnak neki egy ilyen típusú vállalkozásnak, akiknek megszünik az alkalmazotti jogviszonya.

Így összességében 4400 olyan föállásban vállalkozói státuszban levő termelő mutatkozik alkalmasnak az árutermelő gazdasággá válást támogató pályázatra, akiknek célja a fokozottabb piaci jelenlét és a nagyobb üzemméret kialakítása.

A Vidékfejlesztési Program „6.3. Mezőgazdasági kisüzemek fejlesztése” alintézkedése esetében a tervezők figyelembe vették a 2004-2006 között futó Nemzeti Vidékfejlesztési Terv keretében a félig önellátó gazdaságok támogatását célzó intézkedés tapasztalatait, ami azért nem váltotta be a hozzá füzött reményeket, mert a túl alacsony támogatási összeg (1000 euró/év) túl magas követelményekkel párosult. A 2014-2020 közötti Vidékfejlesztési Program kisüzemek támogatását célzó intézkedése keretében adható támogatás az NVT-támogatás háromszorosa, az ÚMVP-ben tervezett támogatás kétszerese. A hét év alatt kisüzemi támogatásban részesülő kedvezményezettek (gazdaságok) tervezett száma 3000 gazdaság, ami reálisnak tűnik a 4000 euró STÉ alatti 3000 (szociológiai alapú becslés) vagy 4400 (jövedelemszerző tevékenység alapú becslés) darabos potenciális pályázói körhöz képest. Ugyanez mondható el a támogatási összegről (kb. 4,6 millió forint) is: mivel az önfoglalkoztató vállalkozók üzemi eszközállománya 5,4 millió forint, ahhoz pedig, hogy fóállássá váljon a mezőgazdasági tevékenység, nagyjából háromszorosára kell növelni az üzemet, ennek a beruházásnak a felét finanszírozza a támogatás. Mindemellett indokolt volna, hogy ezen támogatás mellett a termelö egyéb vidékfejlesztési támogatásokra is jogosult legyen, és lehetőség szerint kedvezményes hitelhez is hozzájusson, mivel - ha föállású termelővé akar válni - szüksége lehet az üzem háromszorosára növeléséhez szükséges harmadik 5 millió forintra. 
Az árutermelővé váló üzemi kör és a kistermelői területalapú támogatást igénybe vevői kör nagyságrendje közötti különbséget az is jól mutatja, hogy míg az EMGA-forrásból finanszírozott, magasabb hektáronkénti támogatást jelentő, de minden más támogatást kizáró formát több mint 50 ezer kistermelő választotta, addig az árutermelövé válni képes kör nagyságrendileg 2-4 ezres lehet. E vélhetően már most is vállalkozóként tevékenykedő kör bizonyosan nem lépett be a kistermelöi támogatási rendszerbe, mivel már eddig is a területalapú támogatás több mint kétszeresét hívta le, így számára csupán évi néhány ezer forintos növekményt jelentene ez a támogatási forma, miközben ki lenne zárva az egyéb támogatások, köztük az árutermelővé válást elősegítő vidékfejlesztési támogatások közül. 


\section{Összefoglalás}

\section{A mezőgazdasági kisüzemek jellemzői és fejlesztési lehetőségei}

Kemény Gábor (szerk.) és Rácz Katalin (szerk.)

A tanulmányban leírtak alapján a következő megállapításokat fogalmazhatjuk meg a mezőgazdasági kisüzemekkel kapcsolatban:

1. A nemzetközi szakirodalom szerint a mezőgazdasági kisüzemek nem tekinthetők egységes, homogén csoportnak, köztük igen jelentős különbségek, tagoltság fedezhető fel. Ez a tagoltság a kistermelés funkcionális összetettségéből ered, a kistermelők között a termelési célok, a piaci beágyazottság, az agrárökonómiai, szociológiai jellemzők és a fóállás jellege szerint is lehetséges a differenciálás. Bár ez a gazdálkodói kör zsugorodik a leggyorsabban a mezőgazdasági termelők táborán belül, a hosszú távú tendenciákat tekintve a kistermelők az önellátási funkció mérséklődése esetén is az agrárstruktúra tartósan jelen lévő szereplői maradnak.

2. Elemzésünk igazolta 1. hipotézisünket, rámutatva, hogy a 4000 euró STÉ alatti kisgazdaságok az Európai Unió mediterrán tagállamaiban, valamint több posztszocialista tagállamban, így Magyarországon is jelentős, nem elhanyagolható szerepet töltenek be a kibocsátásban, a munkaerő-lekötésben és az állattartásban. Érdemi eltérést jelent a mediterrán tagországokhoz képest, hogy - nem függetlenül a létminimum alacsony kelet-közép-európai szintjétől - a kisgazdaságokban megtermelt jövedelemnek a posztszocialista országokban (Lengyelország, Magyarország, Románia, Bulgária, Horvátország, Szlovénia) nagyobb a súlya az EU régi tagállamaihoz képest, jóllehet ez a jövedelem sem alkalmas arra, hogy egymagában önálló egzisztenciát biztosítson mủvelőjének (2. hipotézis igazolása). Két olyan tagállam van, ahol erre a szerepre a kisgazdaság alkalmas: Románia és Bulgária, ahol e gazdaságok nem csupán egzisztenciát biztosítanak, de a mezőgazdasági termelésbeli súlyuk is jóval nagyobb a posztszocialista országokban megszokott 5-15 százaléknál, elérheti akár a 30 százalékot is.

3. Vizsgálatunk alátámasztotta 3. hipotézisünket, mely szerint a mezőgazdasági kisüzemek fő funkciója a más szektorból származó jövedelem kiegészítése. Az egyes termelési méretkategóriák ökonómiai szempontú vizsgálata szerint jellemzően a 8000 euró STÉ feletti gazdaságok nyújtanak elegendő jövedelmet a foállású tevékenység folytatásához, e méretkategória alatt csak kiegészítő tevékenységként végezhető a mezőgazdasági termelés. A 4000 euró STÉ alatti kisgazdaságoknál a családi fogyasztási szükségletek kielégítése mellett a szerény mértékü, létfenntartásra fordítható jövedelmek realizálása jelenik meg elsődleges termelési célként.

4. Kutatásunk a 4000 euró alatti STÉ-vel rendelkező kisüzemek erőteljes szociodemográfiai rétegzettsége mellett arra mutatott rá, hogy a kisgazdaságok körében az átlagnál nagyobb az idősek és fiatalok, nyugdíjasok, munkanélküliek, képzetlenek, női üzemvezetők aránya, míg az árutermelö, 8000 euró STÉ feletti gazdaságokban az átlagosnál nagyobb a középkorúak, foglalkoztatottak, vállalkozók, képzettséggel rendelkezők és a férfi üzemvezetők aránya.

5. A gazdaságok költség-jövedelem viszonyait számviteli elvek szerint vizsgálva megállapítható, hogy a 4000 euró STÉ alatti gazdaságok fajlagosan (hektáronként) magasabb ráfordításokkal, magasabb eszközlekötéssel, nagyobb állatállománnyal, magasabb munkaerő felhasználással állítanak elő magasabb termelési értéket. Azonban számviteli jövedelmük hektáronként és eszközarányosan is alacsonyabb a nagyobb méretkategóriába tartozó üzemeknél, munkaeröarányos jövedelmezőségük (ezzel munkaerö-hatékonyságuk) pedig harmada a 4000-8000 euró STÉ közötti gazdaságokénak. A 4000 euró STÉ alatti gazdaságok gazdasági tevékenységét és jövedelemszerkezetét tekintve ugyanakkor nincs érdemi eltérés az egyes üzemtípusok között. 
A mezőgazdasági tevékenységből származó számviteli jövedelem kevesebb mint tizedét jelenti a háztartások jövedelmének, és kevesebb mint harmadát adja az élelmiszerre fordított összegnek.

6. Vizsgálatunk során igazolást nyert 4. hipotézisünk is, mely szerint a mezőgazdasági kisüzemek gazdálkodását alapvetően a gazdaságvezető gazdasági aktivitásának/foglalkoztatási státuszának jellege határozza meg. A főállású vállalkozók profitorientáltan, magas eszközlekötés és ráfordítás mellett, hatékony munkavégzéssel állítanak elö jelentős jövedelmet, míg a mezőgazdasági és nem mezőgazdasági alkalmazottak, nyugdíjasok és szociális juttatásból élők egyre kisebb ráfordításokkal, egyre kisebb eszközlekötéssel egyre alacsonyabb termelési értéket és jövedelmet állítanak elő, kevésbé hatékony munkaerő-lekötés mellett. E tényezőkből, illetve a kisgazdaságokat jellemző szociológiai háttérből (gazdaságvezető életkora, szakismeretei, jövedelmi helyzete) következően a kisgazdaságoknak csak kis hányada fejleszthető tovább főállású árutermelő gazdasággá (5. hipotézis igazolása).

7. Ha nem számviteli, hanem a fogyasztási cél szempontjából vizsgáljuk meg a fenti csoportok gazdálkodását (a jövedelembe foglalva a saját fogyasztást, az értékcsökkenést, valamint a személyi ráfordításokat) megállapítható, hogy a nem profitorientált mezőgazdasági tevékenységből is igen jelentős, üzemenként 400-500 ezer forintos fogyasztási alap keletkezik, ami a nyugdíjas és szociális juttatásból élő háztartások jövedelmének akár 30 százalékára is rúghat, míg az alkalmazotti réteg jövedelmének 10-16 százalékát is elérheti.

8. A kistermelőkkel folytatott mélyinterjúk megerősítik a fenti megállapításokat, vagyis a tesztüzemi mintában szereplö üzemekben zömében saját fogyasztásra termelö, illetve egyéb bevételeiket (nyugdíj, munkabér, szociális ellátásból származó bevétel) mezőgazdasági tevékenységből kiegészítő gazdálkodók tevékenykednek. E kisgazdaságok megalapítása a rendszerváltás idejére datálható, és szinte mindegyiknél megtalálható a termőföld rendelkezésre állása, az agráriumban való korábbi tevékenység és tapasztalatok, valamint a kiegészítő jövedelemszerzés alternatíváinak hiánya. Ez utóbbi tény figyelembevételének hiánya és a normál piaci folyamatok kisgazdaságokra történő mechanikus vonatkoztatása vezet oda, hogy a tesztüzemi rendszer metodikája szerint elszámolt eredmények alapján a kisgazdaságok csupán minimális jövedelemtermelésre képesek, ami ellentmond a gazdálkodói racionalitásnak. Amint a valós alternatívaköltségekkel kerülnek behelyettesítésre a számviteli tételek, és a kistermelői nézöpontból megfelelő helyen kerülnek elszámolásra, kimutathatóvá válik a kisgazdaságok valódi jelentősége és gazdasági racionalitása.

9. A kisüzemek hosszú távú fennmaradása alapvetően a gazdaságvezető életkorával, illetve a gazdaságot átvenni képes utódokkal áll összefüggésben - a jelentős számú idősebb generáció kilépésével egyszerüsödhet a termelési szerkezet, az aktív korú, illetve a gazdaság átadásának reményében tevékenykedők esetében (ez a réteg a kisebb) növekedés történhet.

10. A mezőgazdasági kisüzemek átfogó vizsgálata választ adott arra a kérdésre is, hogy külső segítség és erőforrások nélkül miért nem lépnek maguktól erre az útra a hátrányos helyzetü térségek szociális juttatásokból élő lakosai, ha ez a tevékenység ilyen komoly jövedelemtöbbletet generálhat. A magyarázat az, hogy nem áll rendelkezésükre az a szaktudás és azok a minimális erőforrások, amelyek lehetővé tennék a kisárutermelővé válást. Ez a felismerés vezette az elmúlt időszak kormányzati és civil kezdeményezésre induló fejlesztési, felzárkóztatási programjait, amelyek közül azok értek el fenntartható eredményeket, amelyek a legnagyobb személyes törödést, valamint a legmagasabb fokú integrációt valósították meg, „,megtanítva” a vidéki lakosoknak az árutermelés termesztési, technológiai alapjait (6. hipotézis igazolása). 


\section{Következtetések, javaslatok}

11. A 4000 euró STÉ alatti kisgazdaságoknak csak szükebb köre - a vállalkozói háttérrel rendelkező, fiatalabb korosztályhoz tartozó, képzettebb és árutermeléssel már korábban is foglalkozó része - lehet potenciális alanya a föállású árutermelővé válást elősegítő Vidékfejlesztési Programnak. A kistermelői réteg túlnyomó része azonban életkori, egzisztenciális okokból és a vállalkozói-profitorientált attitüd hiányában nem alkalmas árutermelésre. A vállalkozói réteg annál is alkalmasabb az árutermelővé válásra, mivel az elmúlt időszakban a KAP-támogatások közül nem csupán a területalapú támogatásokhoz fért hozzá, hanem egyéb, a termelési erőforrások bỏvítését eredményező támogatásokhoz is.

12. Az egyes kisüzemi típusok klaszterelemzéssel történő lehatárolása alapján a mezőgazdasági tevékenység bővítése elsődlegesen azokban az aktív korú gazdaságvezetők által irányított, már jelenleg is piacra termelő kisüzemekben merülhet fel, amelyek magasabb humántőke-ellátottsággal, kiépült üzleti kapcsolatrendszerrel rendelkeznek és a gazdálkodást a jövedelemszerzés szerves részének tekintik. A háztartás jövedelmét más ágazathoz kapcsolódó fötevékenység mellett mezőgazdasággal kiegészítő árutermelő kisüzemekben fejlesztési potenciál főként a piaci alkupozíciót javító integráció erősítésében mutatkozik. A mezőgazdasági tevékenységre alacsony jövedelemszintje miatt legráutaltabb „háztartásgazdaságokban” a humán tőke alacsony szintje a tudástőke bővítését és a termelési erőforrásokhoz, piaci információkhoz való hozzáférést lehetővé tevő horizontális együttmüködések kiterjesztését teszi szükségessé.

13. Az árutermelővé válást elősegítő program iránt érdeklődők körét tovább szükítheti a kisgazdaságok egyszerüsített támogatásának bevezetése, amely akár 100 százalékos támogatásnövekedést jelent, viszont ezzel bezárul a kapu az egyéb vidékfejlesztési támogatások, így az árutermelővé válást elősegítő támogatási konstrukciók előtt. A 2014-2020-as Vidékfejlesztési Programban szereplő, árutermelővé válást elősegítő intézkedés a fentiek alapján megfelelő nagyságrendü támogatást céloz meg kellő számú potenciális jelölt számára.

14. A mezőgazdasági kisüzemek jelentős, más tevékenységből vidéken nem előteremthető jövedelempótlást nyújtanak az érintett háztartások számára, ezzel érdemben javítják a vidéki életfeltételeket, biztosítva az élelmiszer-fogyasztás jelentős részét. Ezt a hatást jelentős mértékben növelni fogja a 2015-től bevezetett kisgazdaságok egyszerüsített támogatása, amely a mezőgazdaságból származó mellékjövedelmek akár 30 százalékos, az összjövedelmeknek pedig a nyugdíjasok és a szociális juttatásból élök esetében akár 10 százalékos növekedését is generálhatja.

15. Az árutermelővé válást elősegítő támogatási forma sikere érdekében fontos lenne, ha a program együtt járna egy kedvezményes hitelkonstrukcióval, illetve lehetővé kellene tenni az egyéb vidékfejlesztési támogatások igénybevételét is, mivel a főállású, hatékony árutermelö üzem eszközállományának megteremtéséhez nagyjából a Vidékfejlesztési Program kisgazdaságok támogatását célzó intézkedésében megjelölt forrás kétszeresére volna szükség.

16. Az árutermelővé nem fejleszthető kisüzemek számának növelése is kívánatos társadalompolitikai és vidékpolitikai szempontból, de csak olyan, a piacra lépést termeléskoordinációval is segítő komplex programok keretében képzelhető el, amelyek a szaktudást is átadják a forgóeszközök mellett, és biztosítják a kiegészítő tevékenységen kívül a föállású jövedelemforrást is, mivel a mezőgazdasági tevékenység önmagában nem válhat fö jövedelemforrássá ilyen kis üzemméret mellett. 



\title{
Summary
}

\section{The characteristics of small farms and their development opportunities in Hungary}

\author{
KEMÉNY, Gábor (eds.) and RÁCZ, Katalin (eds.)
}

As described in the study, the following conclusions may be stated about agricultural small farms:

1. According to the international literature, small farms cannot be considered as a single and homogenous group due to significant differences and fragmentation. This fragmentation originates from the functional complexity of small farming, while production targets, market embeddedness, agro-economic and sociological characteristics, and the nature of primary jobs may result in differences among small farms. However, among the groups of agricultural producers the size of this group is decreasing the fastest. According to long-term trends, small farmers may remain permanently present in the structure of agriculture in case of decline in self-efficiency as well.

2. Our analysis has justified Hypothesis 1 that small farms with Standard Production Value (SPV) below 4000 euros in the EU Mediterranean member states as well as in several post-socialist member states including Hungary play significant roles in output, labour utilisation and animal husbandry. It is a significant difference in comparison to Mediterranean member states that not independently of the low wage levels in Eastern Central Europe - small farm income is of more significance in post-socialist countries (Poland, Hungary, Romania, Bulgaria, Croatia and Slovenia) than in the old EU member states. However, this income is still not enough to provide an independent existence to small farmers (justification of Hypothesis 2). There are only two member states where small farms are suitable for this role: Romania and Bulgaria. Here, farms not only provide subsistence but their importance in production is significantly higher than the usual 5 to 15 per cent in post-socialist countries; it may even reach 30 per cent.

3. Our analysis has confirmed Hypothesis 3, according to which the main function of small farms is to provide income to supplement that from other sectors. According to the analysis of certain production size categories from the economic point of view, farms with SPV over 8000 euros typically provide sufficient income for full-time activity, while below this size category agricultural production can only be carried out as a subsistence activity. This is especially true for small farms with SPV below 4000 euros which, in addition to meeting family consumption needs, start to have the realisation of a low level of income for subsistence as the primary aim of production.

4. In addition to the significant socio-demographic stratification of small farms with SPV below 4000 euros, our research has pointed out that in the case of small farms the shares of elderly and young people, pensioners, unemployed, unskilled and female farmers are higher than the average, while on the commodity producing farms with SPV over 8000 euros the shares of middleaged, employed, entrepreneurs, skilled and male farmers are higher than the average.

5. Analysing cost-income relationships of farms according to accounting principles, it can be stated that farms with SPV below 4000 euros can increase their production values through higher input per unit (hectares), higher machinery use, more livestock and higher labour utilisation. However, their income per hectare and assets are lower than those of bigger farms, their labour proportional profitability (and thus labour efficiency) is one third of farms with SPV between 4000 and 8000 euros. Considering the economic activities and income structure of farms with SPV below 4000 euros, there are no significant differences among farm types. The accounting income from agricultural activities represents less than one tenth of household income, and less than one third of the amount spent on food. 
6. In this study, Hypothesis 4 has also been confirmed, according to which the management of small farms is mainly determined by the economic activity / employment status of the farm leader. Full-time entrepreneurs earn significant income by carrying out profit-oriented, efficient work with high asset utilisation and inputs, while agricultural and non-agricultural employees, pensioners and people living on social allowances produce less and earn less income by lower asset utilisation, lower inputs and less efficient labour utilisation. According to these factors and the sociological background of small farms (age, knowledge and financial capital of farm leader), only a small proportion of small farms can be developed to full-time production (justification of Hypothesis 5).

7. If we do not analyse farming of the above groups from the financial but rather from the consumer target perspective (income includes own consumption, depreciation and personnel expenses), it can be stated that non-profit oriented agricultural activities may generate HUF 400 to 500 thousand consumption base. This may reach 30 per cent of the income of people living from social allowances, and from 10 to 16 per cent of the income of employed people.

8. In-depth interviews carried out with small farmers confirm the above statements that most of the farmers who work on farms included in the Farm Accountancy Data Network (FADN) produce mainly for own consumption or carry out additional agricultural activities to supplement other income (pensions, wages, income from social welfare). These farms were established at the time of the changes in the political system, most of them have their own land, the farmers have years of experience gained from agricultural activities and there is a lack of alternatives to earn supplementary income. The lack of the latter and the mechanical effects of normal market processes on small farms have led to the situation that, according to the results obtained via the methodology of FADN, small farms are only able to produce minimal income which contradicts the rationality of farmers. If the accounting data are replaced by real alternative costs and accounted in the right place from the small farmers' point of view, the real importance and economic rationality of small farms will be realised.

9. The long-term existence of small farms is basically related to the age of the farmers as well as whether there are any successors who are capable of taking over farming. The production structure may become simpler if a significant proportion of the older generation leaves farming activities, as this may increase the numbers of active-aged farmers and of those who wish to take over small farms (this group is smaller).

10. The comprehensive analysis of small farms has answered the question why people living on social allowances and in disadvantaged areas do not choose the path of small farming without external help and resources if this activity may generate such a significant surplus income. The explanation is that they have minimal resources and do not have the necessary expertise which would help them to become small farmers. This recognition has directed development and convergence programmes initiated by the government and civil organisations. These have achieved the greatest personal care and highest level of integration by teaching the rural population the basic knowledge of commodity production and technologies (confirmation of Hypothesis 6).

\section{Conclusions and recommendations}

11. Only a small group of small farms with SPV below 4000 euros - with younger, educated farmers with an entrepreneurial background and production experience - may be potential targets of rural development programmes which provide support to become full-time commodity producers. The majority of small farmers are not capable of commodity production due to age, existential reasons and the lack of a business-profit-oriented attitude. Entrepreneurs are more capable of becoming producers as they could not only benefit from area payments but also other CAP subsidies in order to increase production resources. 
12. Based on the demarcation by cluster analysis of certain small farm types, the extension of agricultural activities mainly occurs on such small farms that are managed by active aged farmers who already produce for the market and have higher human capital, established business networks, and consider farming as an important way to earn income. On small farms which earn household income through main activities in different sectors but also have supplementary agricultural activities, the development potential is mainly in strengthening integration to improve their market position. On the 'household farms' that are the most reliant on agricultural activities due to their low level of income, the low level of human capital requires the improvement of knowledge capital and an increase in horizontal co-operation which together enable access to production resources and market information.

13. The number of farmers interested in programmes that support people to become producers may further decrease due to the introduction of simplified support for small farms. This may increase support by 100 per cent, but it closes the door to other rural development support as well as to support schemes that encourage farmers to become commodity producers. According to the above findings, the sub-programme of the Rural Development Programme 2014-2020 that supports people to become producers aims at the appropriate level of support for the appropriate number of potential candidates.

14. Small farms provide significant supplementary income for households that cannot be earned through any other activities in rural areas, thereby they substantially improve rural living conditions by ensuring the majority of food consumption. This effect will be significantly strengthened by the simplified support for farms introduced in 2015. This may generate a 30 per cent increase in agricultural supplement income and a 10 per cent increase in total income for pensioners and people living from social allowances.

15. In order to ensure the success of support for market-oriented farming the programme should involve favourable credit arrangements, and the application for rural development supports should be widely available as nearly twice the amount of resources that are indicated in the rural development programme measures for supporting small farms would be needed in order to establish full-time, efficient commodity producer farms with sufficient assets.

16. An increase in the number of small farms that cannot be developed for market-oriented production is necessary from the social policy and rural policy perspectives, but this can only be envisaged within the framework of complex programmes supporting market entry by production co-ordination which, in addition to current assets, also deliver knowledge and secure full-time income in addition to supplement activities, as agricultural activity itself may not become the main source of income in the case of such a small farm size. 



\section{Kivonat}

\section{A mezőgazdasági kisüzemek jellemzői és fejlesztési lehetőségei}

Kemény Gábor (szerk.) és Rácz Katalin (szerk.)

Magyarországon a mezőgazdasági kisüzemek az elmúlt évtizedekben a mezőgazdasági termelői kör legnagyobb létszámú és egyben legnagyobb visszaesést elszenvedő csoportját jelentették. Ezek a túlnyomórészt önellátásra termelő, vagy félig önellátó gazdaságok napjainkban is jelentős szerepet játszanak a vidéki háztartások jövedelmének kiegészítésében, de a mezőgazdasági termelés jelentős részének elóállításában is. Kutatásunkban e jellemzően nem piaci árutermeléssel foglalkozó, nem professzionális, 4000 euró STÉ alatti mezőgazdasági kisüzemek helyzetét és jövőbeni kilátásait vizsgáljuk, bemutatjuk föbb ökonómiai, szociológiai paramétereiket, azonosítjuk típusaikat, lehatároljuk az árutermelővé fejleszthető kisüzemek körét, valamint javaslatokat fogalmazunk meg a fejlesztésüket elősegítő eszközrendszerre vonatkozóan.

Eredményeink szerint a kisüzemek gazdálkodását alapvetően gazdasági aktivitásuk határozza meg: a fóállású vállalkozók profitorientáltan, magas eszközlekötés és ráfordítás mellett, hatékony munkavégzéssel állítanak elő jelentős jövedelmet, míg a mezőgazdasági és nem mezőgazdasági alkalmazottak, nyugdíjasok és szociális juttatásokból élők gazdálkodását kisebb ráfordítások és eszközlekötés, alacsonyabb termelési érték és jövedelem, valamint kevésbé hatékony munkaerö-lekötés jellemzi. Vizsgálatunk ugyanakkor arra is felhívta a figyelmet, hogy a nem profitorientált mezőgazdasági tevékenységből is számottevő fogyasztási alap keletkezik, amely a nyugdíjas és szociális juttatásokból élő háztartások jövedelmének jelentős részét, akár harmadát is elérheti.

A kutatás eredményei szerint a 4000 euró STÉ alatti gazdaságok vezetőinek csak kisebb hányada - néhány ezer, jellemzően vállalkozói hátterü, fiatalabb korosztályhoz tartozó, képzettebb és árutermeléssel már korábban is foglalkozó gazdálkodó - esetében reális célkitüzés a fóállású árutermelővé válás. E vállalkozói szemléletű réteg annál is inkább alkalmas erre a szerepre, mivel az elmúlt időszakban a KAP-területalapú támogatások mellett a termelési infrastruktúra fejlesztését lehetővé tevő pályázati forrásokhoz is hozzáfért. A kistermelők túlnyomó része életkori, egzisztenciális okokból és a vállalkozói-profitorientált attitüd hiányában nem alkalmas a fóállású árutermelővé válásra. Fejlesztésük vidékfejlesztési és társadalompolitikai szempontból is kívánatos, de csak olyan komplex programok formájában képzelhető el, amelyek a rendszeres kiegészítő jövedelemszerzést lehetővé tevő termelést kisléptékü fejlesztésekkel, termelés-koordinációval, szaktudással, folyamatos mentorálással segítik. 


\title{
Abstract
}

\section{The characteristics of small farms and their development opportunities in Hungary}

\author{
KEMÉNY, Gábor (eds.) and RÁCZ, Katalin (eds.)
}

The Hungarian small agricultural farms had suffered the biggest setback both in terms of human and economic performance between the circle of agricultural holdings in the last decades. These predominantly subsistence or semi-subsistence farms are playing an important role by supplementing the rural household incomes and also producing the significant part of agricultural production nowadays. In our research, we examined the situation and future prospects of small self-employed farms under EUR $4000 \mathrm{SO}$ which are typically not engaged in market production and are not professional. We are going to present the major economic and social parameters of small farms, identify their types, border the circle of farms develop to market-oriented entities as well as draw up proposals in reference to the tools promoting their development.

Based on the research results, small-scale farming is basically determined by economic activity: the full-time entrepreneurs produce substantial income on a profit-oriented way, with high asset deposition and expenses, and with effective work; while agricultural and non-agricultural workers, pensioners and people living from social benefits produce increasingly low production value and income with decreasing expenses and asset decomposition under less efficient labour contracting. Our analysis, however, has also drawn attention to that significant, even HUF 400-500 thousand consumer base per holding derives from the non-agricultural activity, which can reach up to 30 per cent of incomes to the pensioners and households living from social benefits. This additional income is significant but it cannot be expected without help from outside and resources that people living from social benefits in the disadvantageous rural areas are going to step on the path of self-farming.

The primary reason of that is the lack of expertise and resources which would allow to become market-oriented farm. The results of the research show that by a minority of farm leaders under EUR $4000 \mathrm{SO}-\mathrm{a}$ few thousand farmer having typically entrepreneurial background belonging to the younger age group, more educated and has already dealt with market production - could be a realistic objective to become full-time market-oriented farms. These farms with entrepreneurial approach are more suitable for this role because they had access next to CAP single area payments to tender resources for development. The majority of small farmers are not suitable for full-time production because of existential reasons and the absence of an entrepreneurial and profit-oriented attitude. It would be important towards the success of the present semi-subsistence farms to become marketoriented actors if the RDP would construct a preferential loan and it is necessary to have access to other rural development measures (supports) as well. Their development is desirable from rural development and socio-political points of view but it is conceivable only in the form of complex programs, which enables regular supplementary income with small-scale projects, production coordination, expanding expertise and ongoing mentoring support. 


\section{Mellékletek}

\section{Mellékletek jegyzéke}

1. melléklet: Kistermelői mélyinterjú adatgyüjtő lapja 100

2. melléklet: Az egyéni gazdaságok számának megoszlása méretkategóriák szerint megyei bontásban, 2010

3. melléklet: Az egyéni gazdaságok használt mezőgazdasági területének megoszlása méretkategóriák szerint megyei bontásban, 2010

4. melléklet: Az állattartó egyéni gazdaságok számának megoszlása méretkategóriák szerint megyei bontásban, 2010

5. melléklet: Az egyéni gazdaságokban összesen ledolgozott munkaórák száma és méretkategóriák szerinti megoszlása megyei bontásban, 2010

6. melléklet: Az egyéni gazdaságok nem, STÉ és termelési cél szerinti megoszlása, 2010 110

7. melléklet: Az egyéni gazdaságok életkor, STÉ és termelési cél szerinti megoszlása, 2010

8. melléklet: Az egyéni gazdaságok szakképzettség, STÉ és termelési cél szerint megoszlása, 2010

9. melléklet: Az egyéni gazdaságok gazdasági aktivitás, STÉ és termelési cél szerint megoszlása, 2010

10. melléklet: Egyéni gazdaságok kiegészítő jövedelemszerzés, STÉ és termelési cél szerinti megoszlása, 2010

11. melléklet: Faktoranalízis eredményei 115

12. melléklet: Klaszteranalízis eredményei 
1. melléklet: Kistermelői mélyinterjú adatgyüjtő lapja

\section{KISTERMELÖI ADATLAP}

Az adatlap az Agrárgazdasági Kutató Intézet által végzett felmérés segédeszköze. A kutatás a hazai mezőgazdasági kistermelők gazdálkodásának főbb jellemzőit, fejlődési lehetőségeit vizsgálja, valamint a továbbadható jó példák feltérképezését célozza. A válaszadás önkéntes, a kért adatok és információk kutatási célokat szolgálnak, felhasználásuk, elemzésük a válaszadó megnevezése nélkül, az elöírt adatvédelmi kötelezettségek betartásával történik.

\section{A) A gazdaságra vonatkozó kérdések}

1. A gazdaság alapításának éve:

2. A gazdaság székhelye:

3. Miért kezdett el gazdálkodni? Több választ is megjelölhet!

\begin{tabular}{|l|c|c|c|}
\hline \multicolumn{1}{|c|}{ Gazdálkodás indoka } & \multicolumn{2}{c|}{$\begin{array}{c}1=\text { igen, } \mathbf{2}=\text { nem, } \mathbf{0 = n e m} \\
\text { tudja, nincs válasz }\end{array}$} \\
\hline a. $\quad$ Családi hagyományok & 1 & 2 & 0 \\
\hline b. $\quad$ Mezőgazdasági munka szeretete & 1 & 2 & 0 \\
\hline c. $\quad$ A háztartás számára egészséges élelmiszerek elöállítása & 1 & 2 & 0 \\
\hline d. $\quad$ Mủvelésbe vonható földterület rendelkezésre állása & 1 & 2 & 0 \\
\hline e. $\quad$ Kedvezményes szolgáltatásokat nyújtó integrátori kapcsolat & 1 & 2 & 0 \\
\hline f. $\quad$ Munkalehetöségek hiánya & 1 & 2 & 0 \\
\hline g. $\quad$ Kiegészítő bevételekre utaltság & 1 & 2 & 0 \\
\hline h. $\quad$ Egyéb ok, éspedig ............................................. & 1 & 2 & 0 \\
\hline
\end{tabular}

4. A gazdálkodás keretét adó müködési forma (őstermelés, bt., kft., egyéb):

5. A gazdaság összes használt termőterülete? (mg-terület, konyhakert együttesen) hektár

6. A megmúvelt földterület tulajdon- illetve használati forma szerinti megoszlása:

\begin{tabular}{|c|c|}
\hline Földhasználati forma & Hektár \\
\hline a. Saját tulajdon & \\
\hline b. Bérlet & \\
\hline c. Szívességi használat & \\
\hline d. Egyéb, éspedig..................................................... & \\
\hline e. Összes & \\
\hline
\end{tabular}


7. A gazdaság termelési szerkezete:

\begin{tabular}{|l|l|l|c|}
\hline \multicolumn{1}{|c|}{ Növénytermelés (vetésterület) } & \multicolumn{2}{c|}{ Állattenyésztés (állatállomány) } \\
\hline \multicolumn{1}{|c|}{ Megnevezés } & ha & \multicolumn{1}{c|}{ Megnevezés } & db \\
\hline a. Kalászos gabonafélék & & a. Szarvasmarha & \\
\hline b. Szemes kukorica & Ebből: tejelö tehén & \\
\hline c. Olaj-, hüvelyes és rostnövények & \multicolumn{1}{|c|}{ növendék- és hízóállat } & \\
\hline d. Burgonya & & b. Sertés & \\
\hline e. Cukorrépa & & Ebböl: hízósertés & \\
\hline f. Silókukorica & & \multicolumn{1}{|c|}{ tenyészkoca } & \\
\hline g. Lucerna & & c. Juh & \\
\hline h. Egyéb szántóföldi takarmánynövény & & d. Baromfi & \\
\hline i. Zöldségfélék & & e. Ló & \\
\hline j. Gyümölcsfélék & & f. Kecske & \\
\hline k. Szölö & & g. Egyéb................................. & \\
\hline l. Egyéb..................................... & & h. Egyéb................................... & \\
\hline
\end{tabular}

8. A gazdaság mérete (terület, állatlétszám) az alapítás óta:
a) csökkent
b) nőtt
c) nem változott

9. A gazdaság termelési szerkezete az elmúlt 5 évben:
a) egyszerüsödött
b) bővült
c) nem változott

10. A gazdaság jelenleg tagja-e valamilyen termelői együttműködésnek, szerveződésnek?
a) igen
b) nem

Ha igen, kérjük, nevezze meg az együttmüködés formáját/formáit (TÉSZ, BÉSZ, termelői csoport, egyéb):

B) A gazdaságvezetőre, valamint a gazdaságban munkát végzőkre vonatkozó kérdések
11. A gazdaságvezető neme:
a) férfi
b) nő

12. Családjában korábban gazdálkodott-e valaki (saját felmenők, vagy házastársa felmenői közül)?
a) igen
b) nem
c) nem tudja $\square$ 
13. A gazdaságvezető iskolai végzettsége, szakképzettsége:

\begin{tabular}{|l|c|c|c|c|}
\hline \multicolumn{1}{|c|}{ Megnevezés } & Nincs & Alapfok & $\begin{array}{c}\text { Közép- } \\
\text { fok }\end{array}$ & Felsőfok \\
\hline a. Legmagasabb iskolai végzettség & - & & & \\
\hline b. Legmagasabb mezőgazdasági szakképzettség* & & & & \\
\hline
\end{tabular}

*Az aranykalászos gazdatanfolyam középfokú, az ezüstkalászos gazdatanfolyam alapfokú végzettséget jelent.

\section{A gazdaságban munkát végző családtagok főbb jellemzői:}

\begin{tabular}{|c|c|c|c|c|c|c|c|c|c|c|c|}
\hline \multirow[b]{3}{*}{$\begin{array}{c}\text { Munkát } \\
\text { végzö } \\
\text { státusa* }\end{array}$} & \multirow[b]{3}{*}{$\begin{array}{l}\text { Születési } \\
\text { év }\end{array}$} & \multirow{2}{*}{\multicolumn{3}{|c|}{$\begin{array}{l}\text { Munkavégzés jellege } \\
\text { a gazdaságban }\end{array}$}} & \multicolumn{6}{|c|}{ Gazdasági aktivitás } & \multirow{3}{*}{$\begin{array}{c}\text { A gazda- } \\
\text { ságban } \\
\text { végzett } \\
\text { tevé- } \\
\text { kenység } \\
\text { mun- } \\
\text { kaideje } \\
\text { (munka- } \\
\text { nap/év) }\end{array}$} \\
\hline & & & & & \multirow[b]{2}{*}{ Tanuló } & \multirow[b]{2}{*}{$\begin{array}{c}\text { Nyugdí- } \\
\text { jas }\end{array}$} & \multicolumn{3}{|c|}{ Gazdaságon kívül } & \multirow[b]{2}{*}{$\begin{array}{c}\text { Egyéb } \\
\text { (munka- } \\
\text { nélküli, } \\
\text { inaktív) }\end{array}$} & \\
\hline & & $\begin{array}{c}\text { Teljes } \\
\text { munka- } \\
\text { időben }\end{array}$ & $\begin{array}{c}\text { munka- } \\
\text { időben } \\
\text { (Írja } \\
\text { be, heti } \\
\text { hány } \\
\text { órában!) }\end{array}$ & Egyéb** & & & $\begin{array}{c}\text { Mg-i } \\
\text { alkalma- } \\
\text { zott }\end{array}$ & $\begin{array}{c}\text { Nem } \\
\text { Mg-i } \\
\text { alkalma- } \\
\text { zott }\end{array}$ & $\begin{array}{l}\text { Vállal- } \\
\text { kozó }\end{array}$ & & \\
\hline \multicolumn{12}{|l|}{$\begin{array}{r}\text { 1.Gazda- } \\
\text { ságvezető }\end{array}$} \\
\hline \multicolumn{12}{|l|}{2.} \\
\hline \multicolumn{12}{|l|}{3.} \\
\hline \multicolumn{12}{|l|}{4.} \\
\hline 5. & & & & & & & & & & & \\
\hline
\end{tabular}

*Például házastárs, gyermek, nagyszülő

**Például szívesség, természetbeni juttatás

15. A gazdaságban munkát végző idegen munkaerő főbb jellemzői:

\begin{tabular}{|c|c|c|c|c|c|c|c|c|c|c|c|}
\hline \multirow[b]{3}{*}{$\begin{array}{c}\text { Munkát } \\
\text { végző } \\
\text { státusa* }\end{array}$} & \multirow[b]{3}{*}{$\begin{array}{l}\text { Születési } \\
\text { év }\end{array}$} & \multirow{2}{*}{\multicolumn{3}{|c|}{$\begin{array}{c}\text { Munkavégzés jellege } \\
\text { a gazdaságban }\end{array}$}} & \multicolumn{6}{|c|}{ Gazdasági aktivitás } & \multirow{3}{*}{$\begin{array}{c}\text { A gazda- } \\
\text { ságban } \\
\text { végzett } \\
\text { tevé- } \\
\text { kenység } \\
\text { mun- } \\
\text { kaideje } \\
\text { (munka- } \\
\text { nap/év) }\end{array}$} \\
\hline & & & & & \multirow[b]{2}{*}{ Tanuló } & \multirow[b]{2}{*}{$\begin{array}{l}\text { Nyugdí- } \\
\text { jas }\end{array}$} & \multicolumn{3}{|c|}{ Gazdaságon kívül } & \multirow[b]{2}{*}{$\begin{array}{c}\text { Egyéb } \\
\text { (munka- } \\
\text { nélküli, } \\
\text { inaktív) }\end{array}$} & \\
\hline & & $\begin{array}{c}\text { Teljes } \\
\text { munka- } \\
\text { időben }\end{array}$ & $\begin{array}{c}\text { Rész- } \\
\text { munka- } \\
\text { időben } \\
\text { (Írja } \\
\text { be, heti } \\
\text { hány } \\
\text { órában!) }\end{array}$ & Egyéb** & & & $\begin{array}{c}\text { Mg-i } \\
\text { alkalma- } \\
\text { zott }\end{array}$ & $\begin{array}{c}\text { Nem } \\
\text { Mg-i } \\
\text { alkalma- } \\
\text { zott }\end{array}$ & $\begin{array}{l}\text { Vállal- } \\
\text { kozó }\end{array}$ & & \\
\hline \multicolumn{12}{|l|}{$\begin{array}{r}\text { 1.Gazda- } \\
\text { ságvezető }\end{array}$} \\
\hline \multicolumn{12}{|l|}{2.} \\
\hline \multicolumn{12}{|l|}{3.} \\
\hline \multicolumn{12}{|l|}{4.} \\
\hline 5. & & & & & & & & & & & \\
\hline
\end{tabular}

*Például napszámos, helyi szolgáltató

**Például szívesség, természetbeni juttatás 


\section{C) A gazdálkodással kapcsolatos kérdések}

16. A gazdálkodási tevékenység célja szerint az Önök gazdasága:
a) Elsősorban árutermelö kisüzem
b) Elsősorban saját fogyasztásra termelő kisüzem
c) Saját fogyasztásra és árutermelésre egyaránt termelő kisüzem

17. Ha árutermeléssel is foglalkoznak, melyek azok a termékek, amelyeket értékesítenek?

\begin{tabular}{|c|c|c|c|c|c|c|c|}
\hline \multirow{3}{*}{$\begin{array}{c}\text { Termék } \\
\text { a. } \\
\end{array}$} & \multirow{3}{*}{$\begin{array}{c}\text { Megtermelt } \\
\text { mennyiség } \\
\text { (mázsa/kg/ } \\
\text { db/) }\end{array}$} & \multicolumn{2}{|c|}{$\begin{array}{c}\text { Értékesített } \\
\text { mennyiség aránya (\%) }\end{array}$} & \multirow{2}{*}{\multicolumn{4}{|c|}{$\begin{array}{c}\text { Értékesítés módja } \\
1 \text { - Közvetlenül a fogyasztóknak } \\
2 \text {-Helyi kiskereskedőnek, kofának } \\
\text { 3- Termelői szerveződésnek, } \\
\text { integrátornak } \\
\text { 4- Egyéb helyen }\end{array}$}} \\
\hline & & \multirow[t]{2}{*}{$\begin{array}{l}\text { Friss ter- } \\
\text { mékként }\end{array}$} & \multirow[t]{2}{*}{$\begin{array}{l}\text { Feldolgozott } \\
\text { termékként }\end{array}$} & & & & \\
\hline & & & & 1 & 2 & 3 & 4 \\
\hline b. & & & & 1 & 2 & 3 & 4 \\
\hline c. & & & & 1 & 2 & 3 & 4 \\
\hline d. & & & & 1 & 2 & 3 & 4 \\
\hline e. & & & & 1 & 2 & 3 & 4 \\
\hline f. & & & & 1 & 2 & 3 & 4 \\
\hline g. & & & & 1 & 2 & 3 & 4 \\
\hline
\end{tabular}

18. A gazdaság milyen alaptevékenységen kívüli tevékenységgel foglalkozik? Több választ is megjelölhet!
a) Termékfeldolgozás
b) Mezőgazdasági szolgáltatás (gépi-müszaki, kereskedelmi)
c) Falusi turizmus, vendégfogadás
d) Kézmüvesség
e) Egyéb, éspedig

19. Egy átlagos évet alapul véve hogyan alakul háztartásuk bevételi szerkezete?

\begin{tabular}{|l|c|}
\hline \multicolumn{1}{|c|}{ Megnevezés } & $\begin{array}{c}\text { Megoszlás } \\
(\%)\end{array}$ \\
\hline a. $\quad$ Bérjellegú jövedelem & \\
\hline b. $\quad$ Nyugdíj & \\
\hline c. $\quad$ Álláskeresők járadéka & \\
\hline d. $\quad$ Szociális ellátások, juttatások & \\
\hline e. $\quad$ Gazdálkodás alaptevékenységéböl (növ.termelés, állattenyésztés) befolyó árbevétel & \\
\hline f. $\quad$ Gazdálkodás alaptevékenységen kívüli tevékenységéböl származó árbevétel & \\
\hline g. $\quad$ Földalapú támogatásból & \\
\hline h. Egyéb bevétel éspedig........................................ & $\mathbf{1 0 0}$ \\
\hline Összes: &
\end{tabular}




\section{Egy átlagos évet alapul véve hogyan alakul háztartásuk kiadási szerkezete?}

\begin{tabular}{|c|c|}
\hline Megnevezés & $\begin{array}{c}\text { Megoszlás } \\
(\%)\end{array}$ \\
\hline a. $\quad$ Rezsiköltségek & \\
\hline b. Élelmiszerköltségek & \\
\hline c. $\quad$ Földbérleti díj & \\
\hline d. Gazdálkodás müködtetésével kapcsolatos kiadások & \\
\hline \multicolumn{2}{|l|}{ Ebböl: d.1. Mütrágya } \\
\hline d.2. Takarmány & \\
\hline d.3. Növényvédöszer & \\
\hline d.4. Gépi szolgáltatás (szántás, vetés, aratás) & \\
\hline e. $\quad$ A gazdaság fejlesztésére fordított kiadások & \\
\hline f. $\quad$ Egyéb kiadások, éspedig.......................... & \\
\hline Összes: & 100 \\
\hline
\end{tabular}

\section{Kérjük, az alábbiak szerint minősítse háztartása megélhetésének színvonalát!}

\begin{tabular}{|l|c|}
\hline \multicolumn{1}{|c|}{ Megnevezés } & $\begin{array}{c}\text { X-elje a } \\
\text { megfelelő } \\
\text { választ! }\end{array}$ \\
\hline a. A család napi megélhetési (élelmiszer, gyógyszerellátás, rezsi kifizetés) gondokkal küzd & \\
\hline b. Az alapvető szükségletek fedezete megoldott, de a nagyobb kiadások gondot jelentenek & \\
\hline c. A család megélhetése biztonságos, de a megtakarítás mértéke szerény & \\
\hline $\begin{array}{l}\text { d. A család jövedelme fedezetet nyújt megtakarításra és az életminőség javítására is } \\
\text { (gyermekek taníttatása, üdültetése stb.) }\end{array}$ & \\
\hline e.A család jövedelme fedezetet nyújt a gazdaság fejlesztésére is & \\
\hline
\end{tabular}

\section{A gazdaság eszközellátottsága}

\begin{tabular}{|l|c|}
\hline \multicolumn{1}{|c|}{ Megnevezés } & $\begin{array}{c}\text { X-elje a } \\
\text { megfelelő } \\
\text { választ! }\end{array}$ \\
\hline a. Alapvető kézi szerszámok & \\
\hline b. Elektromos/robbanómotoros eszközök (pl. rotációs kapa, motoros permetezőgép, darálógép) & \\
\hline c. Erőgépek (traktor, vetőgép, rakodógép) & \\
\hline d. Egyéb, fontosnak tartott, éspedig...................................... & \\
\hline
\end{tabular}

\section{Az elmúlt öt évben pályázott-e a gazdaság fejlesztését célzó támogatásra?}
a) igen
b) nem

Ha igen, mire és milyen összegben? 
24. Az elmúlt öt évben a gazdaság fejlesztéséhez vett-e igénybe bankhitelt?
a) igen
b) nem

Ha igen, mire és milyen összegben?

25. Ha lenne lehetősége, mit fejlesztene? (földterület, technológia, szaktudás, stb).

26. Milyen, a gazdaság jövőjére vonatkozó elképzelései(k) vannak? (pl. a gazdaság tevékenységi körének bővítése, továbbadás az utódoknak, mezőgazdasági tevékenységgel való felhagyás)

Kérdezés ideje:

Kérdező neve: 
2. melléklet: Az egyéni gazdaságok számának megoszlása méretkategóriák szerint megyei bontásban, 2010

\begin{tabular}{|c|c|c|c|c|c|}
\hline \multirow[b]{2}{*}{ Megye } & \multirow{2}{*}{$\begin{array}{c}\text { Egyéni } \\
\text { gazdaságok } \\
\text { száma, darab }\end{array}$} & \multicolumn{4}{|c|}{ Egyéni gazdaságok megoszlása, százalék } \\
\hline & & $\begin{array}{l}2000 \text { euró } \\
\text { STÉ alatt }\end{array}$ & $\begin{array}{c}\text { 2000-4000 } \\
\text { euró STÉ }\end{array}$ & $\begin{array}{l}\text { 4000-8000 } \\
\text { euró STÉ }\end{array}$ & $\begin{array}{l}8000 \text { euró } \\
\text { STÉ felett }\end{array}$ \\
\hline \multicolumn{6}{|c|}{ Közép-Magyarország } \\
\hline Budapest & 1225 & 75,32 & 7,65 & 5,10 & 11,93 \\
\hline Pest megye & 45749 & 74,53 & 12,96 & 5,62 & 6,88 \\
\hline \multicolumn{6}{|c|}{ Közép-Dunántúl } \\
\hline Fejér megye & 23493 & 69,40 & 15,71 & 6,47 & 8,42 \\
\hline Komárom-Esztergom megye & 10596 & 75,63 & 11,34 & 5,16 & 7,86 \\
\hline Veszprém megye & 16864 & 75,14 & 11,56 & 5,79 & 7,51 \\
\hline \multicolumn{6}{|c|}{ Dél-Dunántúl } \\
\hline Baranya megye & 20685 & 66,52 & 17,79 & 7,27 & 8,42 \\
\hline Somogy megye & 32612 & 67,88 & 18,36 & 6,97 & 6,79 \\
\hline Tolna megye & 19996 & 60,59 & 19,67 & 8,48 & 11,27 \\
\hline \multicolumn{6}{|c|}{ Nyugat-Dunántúl } \\
\hline Győr-Moson-Sopron megye & 17387 & 65,68 & 12,49 & 8,45 & 13,37 \\
\hline Vas megye & 16921 & 74,98 & 11,06 & 6,16 & 7,80 \\
\hline Zala megye & 25648 & 74,28 & 14,29 & 5,69 & 5,74 \\
\hline \multicolumn{6}{|c|}{ Észak-Magyarország } \\
\hline Borsod-Abaúj-Zemplén megye & 43749 & 72,34 & 16,77 & 5,91 & 4,99 \\
\hline Heves megye & 17477 & 66,71 & 16,74 & 7,95 & 8,59 \\
\hline Nógrád megye & 10611 & 75,04 & 14,00 & 5,51 & 5,45 \\
\hline \multicolumn{6}{|c|}{ Észak-Alföld } \\
\hline Hajdú-Bihar megye & 45183 & 60,61 & 18,96 & 9,70 & 10,74 \\
\hline Jász-Nagykun-Szolnok megye & 25970 & 59,92 & 18,06 & 9,61 & 12,41 \\
\hline Szabolcs-Szatmár-Bereg megye & 70926 & 66,15 & 16,83 & 8,77 & 8,25 \\
\hline \multicolumn{6}{|c|}{ Dél-Alföld } \\
\hline Bács-Kiskun megye & 53793 & 61,89 & 14,71 & 9,63 & 13,77 \\
\hline Békés megye & 36836 & 56,52 & 17,75 & 11,62 & 14,10 \\
\hline Csongrád megye & 31870 & 55,76 & 15,76 & 11,48 & 17,00 \\
\hline Összesen, darab & 567581 & 376180 & 90596 & 45902 & 54903 \\
\hline
\end{tabular}

Forrás: ÁMÖ 2010 alapján AKI Vidékfejlesztési Kutatási Osztály 
3. melléklet: Az egyéni gazdaságok használt mezőgazdasági területének megoszlása méretkategóriák szerint megyei bontásban, 2010

\begin{tabular}{|c|c|c|c|c|c|}
\hline \multirow{2}{*}{ Megye } & \multirow{2}{*}{$\begin{array}{c}\text { Egyéni } \\
\text { gazdaságok } \\
\text { használt mezőgaz- } \\
\text { dasági területe, } \\
\text { hektár }\end{array}$} & \multicolumn{4}{|c|}{$\begin{array}{c}\text { Egyéni gazdaságok használt mezőgazdasági } \\
\text { területe, százalék }\end{array}$} \\
\hline & & $\begin{array}{l}2000 \text { euró } \\
\text { STÉ alatt }\end{array}$ & $\begin{array}{l}\text { 2000-4000 } \\
\text { euró STÉ }\end{array}$ & $\begin{array}{l}\text { 4000-8000 } \\
\text { euró STÉ }\end{array}$ & $\begin{array}{l}8000 \text { euró } \\
\text { STÉ felett }\end{array}$ \\
\hline \multicolumn{6}{|c|}{ Közép-Magyarország } \\
\hline Budapest & 9702 & 13,77 & 8,30 & 5,98 & 71,95 \\
\hline Pest megye & 131460 & 10,96 & 6,14 & 8,47 & 74,42 \\
\hline \multicolumn{6}{|c|}{ Közép-Dunántúl } \\
\hline Fejér megye & 109235 & 4,48 & 3,40 & 5,67 & 86,44 \\
\hline Komárom-Esztergom megye & 44488 & 6,46 & 4,28 & 6,85 & 82,42 \\
\hline Veszprém megye & 71495 & 7,55 & 4,97 & 7,26 & 80,22 \\
\hline \multicolumn{6}{|c|}{ Dél-Dunántúl } \\
\hline Baranya megye & 73489 & 5,55 & 4,29 & 6,48 & 83,68 \\
\hline Somogy megye & 102416 & 7,54 & 5,00 & 6,62 & 80,85 \\
\hline Tolna megye & 109491 & 3,41 & 2,92 & 5,76 & 87,92 \\
\hline \multicolumn{6}{|c|}{ Nyugat-Dunántúl } \\
\hline Győr-Moson-Sopron megye & 105193 & 4,43 & 4,09 & 7,63 & 83,86 \\
\hline Vas megye & 64738 & 6,55 & 4,23 & 7,48 & 81,73 \\
\hline Zala megye & 67970 & 9,29 & 5,36 & 7,36 & 77,99 \\
\hline \multicolumn{6}{|c|}{ Észak-Magyarország } \\
\hline Borsod-Abaúj-Zemplén megye & 132404 & 9,18 & 5,86 & 8,04 & 76,92 \\
\hline Heves megye & 84746 & 7,90 & 5,61 & 8,75 & 77,75 \\
\hline Nógrád megye & 37792 & 11,73 & 7,66 & 10,22 & 70,39 \\
\hline \multicolumn{6}{|c|}{ Észak-Alföld } \\
\hline Hajdú-Bihar megye & 214395 & 5,73 & 6,66 & 11,23 & 76,38 \\
\hline Jász-Nagykun-Szolnok megye & 180744 & 3,73 & 4,22 & 7,64 & 84,41 \\
\hline Szabolcs-Szatmár-Bereg megye & 228429 & 9,16 & 7,93 & 12,07 & 70,84 \\
\hline \multicolumn{6}{|c|}{ Dél-Alföld } \\
\hline Bács-Kiskun megye & 282467 & 7,63 & 6,61 & 10,13 & 75,62 \\
\hline Békés megye & 222636 & 3,86 & 4,55 & 9,21 & 82,39 \\
\hline Csongrád megye & 145425 & 8,42 & 6,63 & 10,46 & 74,49 \\
\hline Összesen, hektár & 2418716 & 165282 & 134053 & 213594 & 1905786 \\
\hline
\end{tabular}


4. melléklet: Az állattartó egyéni gazdaságok számának megoszlása méretkategóriák szerint megyei bontásban, 2010

\begin{tabular}{|c|c|c|c|c|c|}
\hline \multirow{2}{*}{ Megye } & \multirow{2}{*}{$\begin{array}{c}\text { Az állattartó } \\
\text { egyéni } \\
\text { gazdaságok } \\
\text { száma, darab }\end{array}$} & \multicolumn{4}{|c|}{$\begin{array}{c}\text { Az állattartó egyéni gazdaságok számának } \\
\text { megoszlása, százalék }\end{array}$} \\
\hline & & $\begin{array}{l}\text { 2000 euró } \\
\text { STÉ alatt }\end{array}$ & $\begin{array}{c}2000-4000 \\
\text { euró STÉ }\end{array}$ & $\begin{array}{l}\text { 4000-8000 } \\
\text { euró STÉ }\end{array}$ & $\begin{array}{l}8000 \text { euró } \\
\text { STÉ felett }\end{array}$ \\
\hline \multicolumn{6}{|c|}{ Közép-Magyarország } \\
\hline Budapest & 63 & 42,86 & 17,46 & 9,52 & 30,16 \\
\hline Pest megye & 29448 & 69,14 & 17,52 & 6,66 & 6,68 \\
\hline \multicolumn{6}{|c|}{ Közép-Dunántúl } \\
\hline Fejér megye & 16192 & 62,67 & 21,23 & 7,87 & 8,24 \\
\hline Komárom-Esztergom megye & 6644 & 69,55 & 15,79 & 6,56 & 8,10 \\
\hline Veszprém megye & 9125 & 64,27 & 17,74 & 8,28 & 9,70 \\
\hline \multicolumn{6}{|c|}{ Dél-Dunántúl } \\
\hline Baranya megye & 13802 & 57,35 & 24,75 & 9,13 & 8,77 \\
\hline Somogy megye & 20650 & 58,06 & 25,85 & 9,09 & 7,01 \\
\hline Tolna megye & 13646 & 52,91 & 26,74 & 9,94 & 10,41 \\
\hline \multicolumn{6}{|c|}{ Nyugat-Dunántúl } \\
\hline Győr-Moson-Sopron megye & 11333 & 60,73 & 16,07 & 9,68 & 13,53 \\
\hline Vas megye & 9889 & 66,36 & 16,18 & 8,45 & 9,01 \\
\hline Zala megye & 16034 & 65,23 & 20,77 & 7,68 & 6,32 \\
\hline \multicolumn{6}{|c|}{ Észak-Magyarország } \\
\hline Borsod-Abaúj-Zemplén megye & 27597 & 61,94 & 24,51 & 7,99 & 5,56 \\
\hline Heves megye & 9315 & 60,47 & 22,95 & 9,00 & 7,58 \\
\hline Nógrád megye & 7650 & 70,34 & 17,74 & 6,33 & 5,59 \\
\hline \multicolumn{6}{|c|}{ Észak-Alföld } \\
\hline Hajdú-Bihar megye & 33015 & 56,98 & 22,39 & 10,46 & 10,17 \\
\hline Jász-Nagykun-Szolnok megye & 20531 & 58,79 & 20,27 & 9,87 & 11,07 \\
\hline Szabolcs-Szatmár-Bereg megye & 45034 & 56,91 & 22,98 & 11,24 & 8,87 \\
\hline \multicolumn{6}{|c|}{ Dél-Alföld } \\
\hline Bács-Kiskun megye & 37715 & 58,88 & 16,87 & 10,36 & 13,89 \\
\hline Békés megye & 29217 & 57,64 & 19,30 & 11,60 & 11,47 \\
\hline Csongrád megye & 22542 & 53,04 & 17,99 & 12,34 & 16,63 \\
\hline Összesen, darab & 379442 & 227671 & 78645 & 36244 & 36882 \\
\hline
\end{tabular}

Forrás: ÁMÖ 2010 alapján AKI Vidékfejlesztési Kutatási Osztály 
5. melléklet: Az egyéni gazdaságokban összesen ledolgozott munkaórák száma és méretkategóriák szerinti megoszlása megyei bontásban, 2010

\begin{tabular}{|c|c|c|c|c|c|}
\hline \multirow{2}{*}{ Megye } & \multirow{2}{*}{$\begin{array}{c}\text { Az egyéni } \\
\text { gazdaságokban } \\
\text { ledolgozott } \\
\text { munkaórák } \\
\text { száma, ÉME } \\
\end{array}$} & \multicolumn{4}{|c|}{$\begin{array}{c}\text { Az egyéni gazdaságokban ledolgozott munkaórák } \\
\text { megoszlása, százalék }\end{array}$} \\
\hline & & $\begin{array}{l}2000 \text { euró } \\
\text { STÉ alatt }\end{array}$ & $\begin{array}{l}2000-4000 \\
\text { euró STÉ }\end{array}$ & $\begin{array}{l}\text { 4000-8000 } \\
\text { euró STÉ }\end{array}$ & $\begin{array}{l}8000 \text { euró } \\
\text { STÉ felett }\end{array}$ \\
\hline \multicolumn{6}{|c|}{ Közép-Magyarország } \\
\hline Budapest & 680 & 61,54 & 10,34 & 8,03 & 20,09 \\
\hline Pest megye & 29209 & 58,77 & 14,80 & 8,93 & 17,50 \\
\hline \multicolumn{6}{|c|}{ Közép-Dunántúl } \\
\hline Fejér megye & 15746 & 55,52 & 16,41 & 8,69 & 19,38 \\
\hline Komárom-Esztergom megye & 6675 & 60,73 & 11,96 & 7,35 & 19,95 \\
\hline Veszprém megye & 10968 & 60,07 & 12,82 & 8,48 & 18,63 \\
\hline \multicolumn{6}{|c|}{ Dél-Dunántúl } \\
\hline Baranya megye & 12105 & 52,19 & 17,33 & 9,62 & 20,86 \\
\hline Somogy megye & 20373 & 50,63 & 19,78 & 9,45 & 20,14 \\
\hline Tolna megye & 12429 & 44,52 & 18,91 & 11,06 & 25,52 \\
\hline \multicolumn{6}{|c|}{ Nyugat-Dunántúl } \\
\hline Győr-Moson-Sopron megye & 12237 & 44,33 & 12,33 & 10,41 & 32,94 \\
\hline Vas megye & 9602 & 59,20 & 13,04 & 9,16 & 18,60 \\
\hline Zala megye & 15524 & 61,12 & 17,10 & 8,98 & 12,80 \\
\hline \multicolumn{6}{|c|}{ Észak-Magyarország } \\
\hline Borsod-Abaúj-Zemplén megye & 24068 & 56,67 & 18,48 & 9,54 & 15,31 \\
\hline Heves megye & 12614 & 42,58 & 16,88 & 12,02 & 28,51 \\
\hline Nógrád megye & 6358 & 60,48 & 17,37 & 8,67 & 13,48 \\
\hline \multicolumn{6}{|c|}{ Észak-Alföld } \\
\hline Hajdú-Bihar megye & 26071 & 44,00 & 18,83 & 12,54 & 24,64 \\
\hline Jász-Nagykun-Szolnok megye & 17136 & 42,33 & 17,78 & 12,64 & 27,24 \\
\hline Szabolcs-Szatmár-Bereg megye & 38879 & 44,27 & 16,97 & 12,82 & 25,94 \\
\hline \multicolumn{6}{|c|}{ Dél-Alföld } \\
\hline Bács-Kiskun megye & 40923 & 38,39 & 15,14 & 13,28 & 33,19 \\
\hline Békés megye & 24176 & 39,08 & 17,76 & 15,30 & 27,85 \\
\hline Csongrád megye & 26219 & 33,53 & 15,26 & 15,28 & 35,93 \\
\hline Összesen, ÉME & 361992 & 172479 & 59801 & 41383 & 88329 \\
\hline
\end{tabular}

Forrás: ÁMÖ 2010 alapján AKI Vidékfejlesztési Kutatási Osztály 
6. melléklet: Az egyéni gazdaságok nem, STÉ és termelési cél szerinti megoszlása, 2010

\begin{tabular}{|c|c|c|c|c|c|c|}
\hline \multirow{2}{*}{ Megnevezés } & \multicolumn{2}{|c|}{ Nő } & \multicolumn{2}{|c|}{ Férfi } & \multicolumn{2}{|c|}{ Összes } \\
\hline & száma & aránya & száma & aránya & száma & aránya \\
\hline \multicolumn{7}{|c|}{2000 euró STÉ alatt } \\
\hline Összes & 112627 & 100 & 267505 & 100 & 380132 & 100 \\
\hline Saját fogyasztásra termelö & 82819 & 73,5 & 198499 & 74,2 & 281318 & 74,0 \\
\hline Félig önellátó & 18235 & 16,2 & 43489 & 16,3 & 61724 & 16,2 \\
\hline Elsősorban értékesítésre termelő & 11565 & 10,3 & 25342 & 9,5 & 36907 & 9,7 \\
\hline Mezőgazdasági szolgáltatás & 8 & 0,0 & 175 & 0,1 & 183 & 0,0 \\
\hline \multicolumn{7}{|c|}{ 2000-4000 euró STÉ } \\
\hline Összes & 20819 & 100 & 67061 & 100 & 87880 & 100 \\
\hline Saját fogyasztásra termelö & 11638 & 55,9 & 35805 & 53,4 & 47443 & 54,0 \\
\hline Félig önellátó & 4916 & 23,6 & 18097 & 27,0 & 23013 & 26,2 \\
\hline Elsősorban értékesítésre termelő & 4265 & 20,5 & 13159 & 19,6 & 17424 & 19,8 \\
\hline \multicolumn{7}{|c|}{ 4000-8000 euró STÉ } \\
\hline Összes & 8311 & 100 & 36822 & 100,0 & 45133 & 100,0 \\
\hline Saját fogyasztásra termelő & 1856 & 22,3 & 8799 & 23,9 & 10655 & 23,6 \\
\hline Félig önellátó & 2733 & 32,9 & 13640 & 37,0 & 16373 & 36,3 \\
\hline Elsősorban értékesítésre termelő & 3722 & 44,8 & 14383 & 39,1 & 18105 & 40,1 \\
\hline \multicolumn{7}{|c|}{8000 euró STÉ fölött } \\
\hline Összes & 8258 & 100 & 46226 & 100 & 54484 & 100 \\
\hline Saját fogyasztásra termelö & 318 & 3,9 & 1743 & 3,8 & 2061 & 3,8 \\
\hline Félig önellátó & 1944 & 23,5 & 12120 & 26,2 & 14064 & 25,8 \\
\hline Elsősorban értékesítésre termelő & 5996 & 72,6 & 32363 & 70,0 & 38359 & 70,4 \\
\hline \multicolumn{7}{|c|}{ Összes gazdaság } \\
\hline Összes & 150015 & 100 & 417614 & 100 & 567629 & 100 \\
\hline Saját fogyasztásra termelö & 96631 & 64,4 & 244846 & 58,6 & 341477 & 60,2 \\
\hline Félig önellátó & 27828 & 18,6 & 87346 & 20,9 & 115174 & 20,3 \\
\hline Elsősorban értékesítésre termelő & 25548 & 17,0 & 85247 & 20,4 & 110795 & 19,5 \\
\hline Mezőgazdasági szolgáltatás & 8 & 0,0 & 175 & 0,0 & 183 & 0,0 \\
\hline
\end{tabular}

Forrás: ÁMÖ 2010 alapján AKI Vidékfejlesztési Kutatási Osztály 


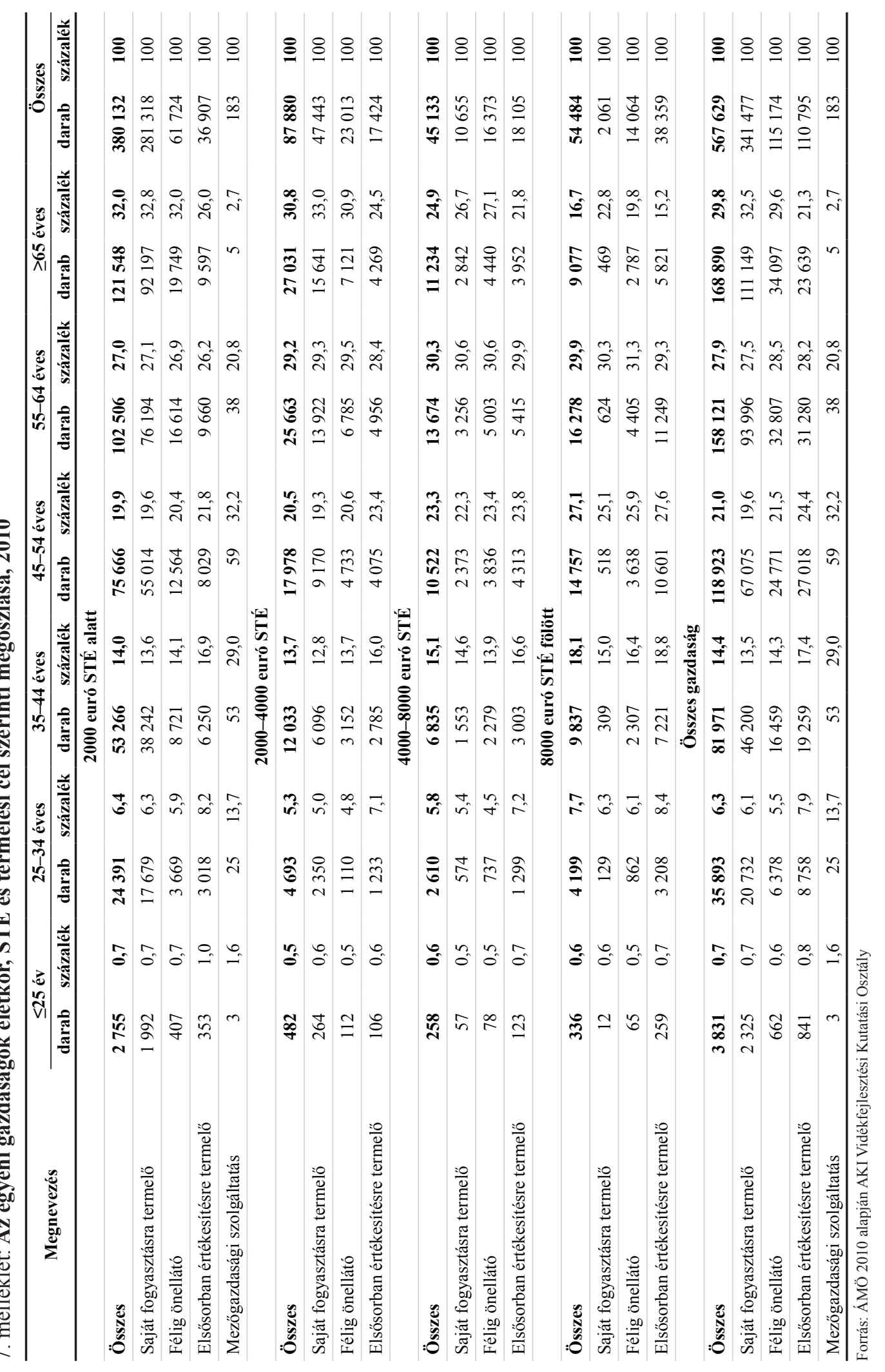




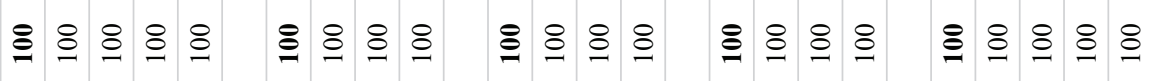

豙

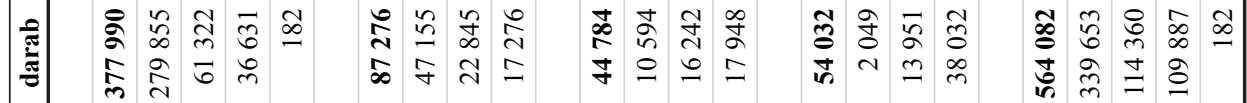

离

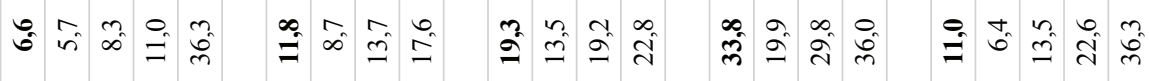

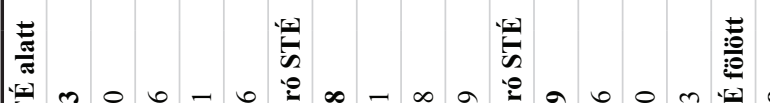

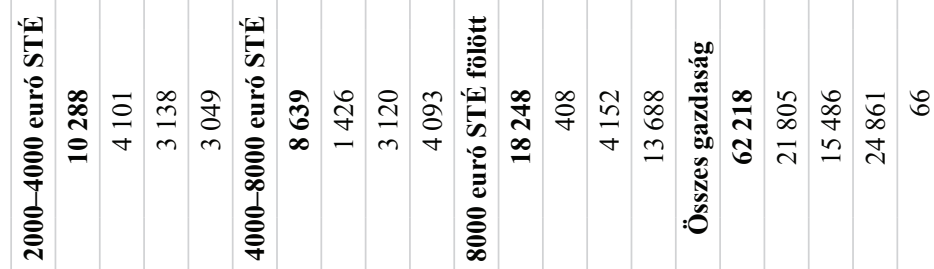

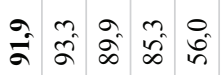

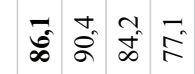

în

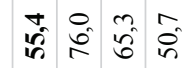

की.

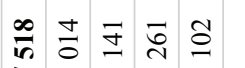

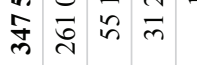

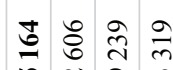

\&

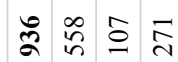

ㄱㄱㅇㅢ $\mathrm{m} \infty \simeq$

ลे

ปั้ ปิ

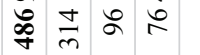

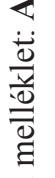
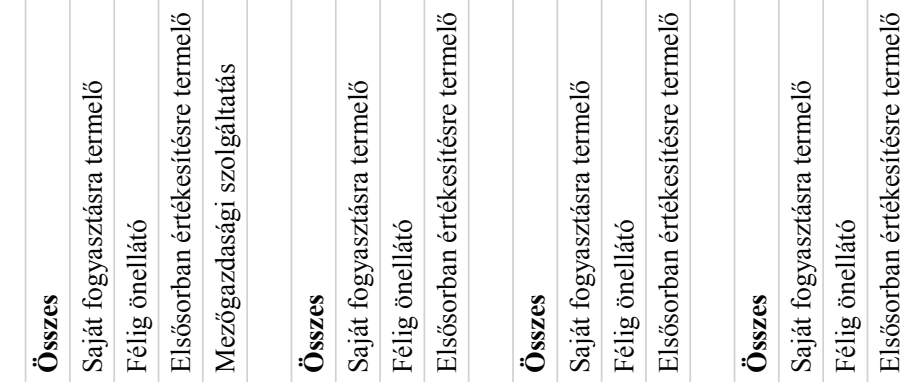

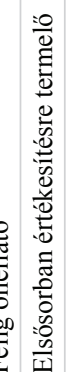

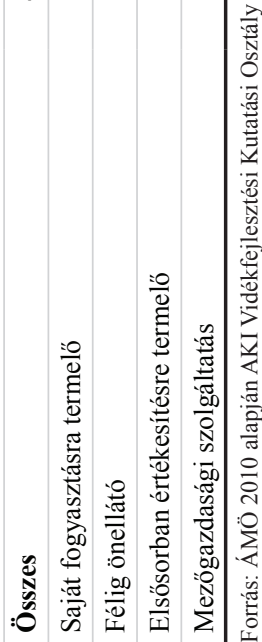




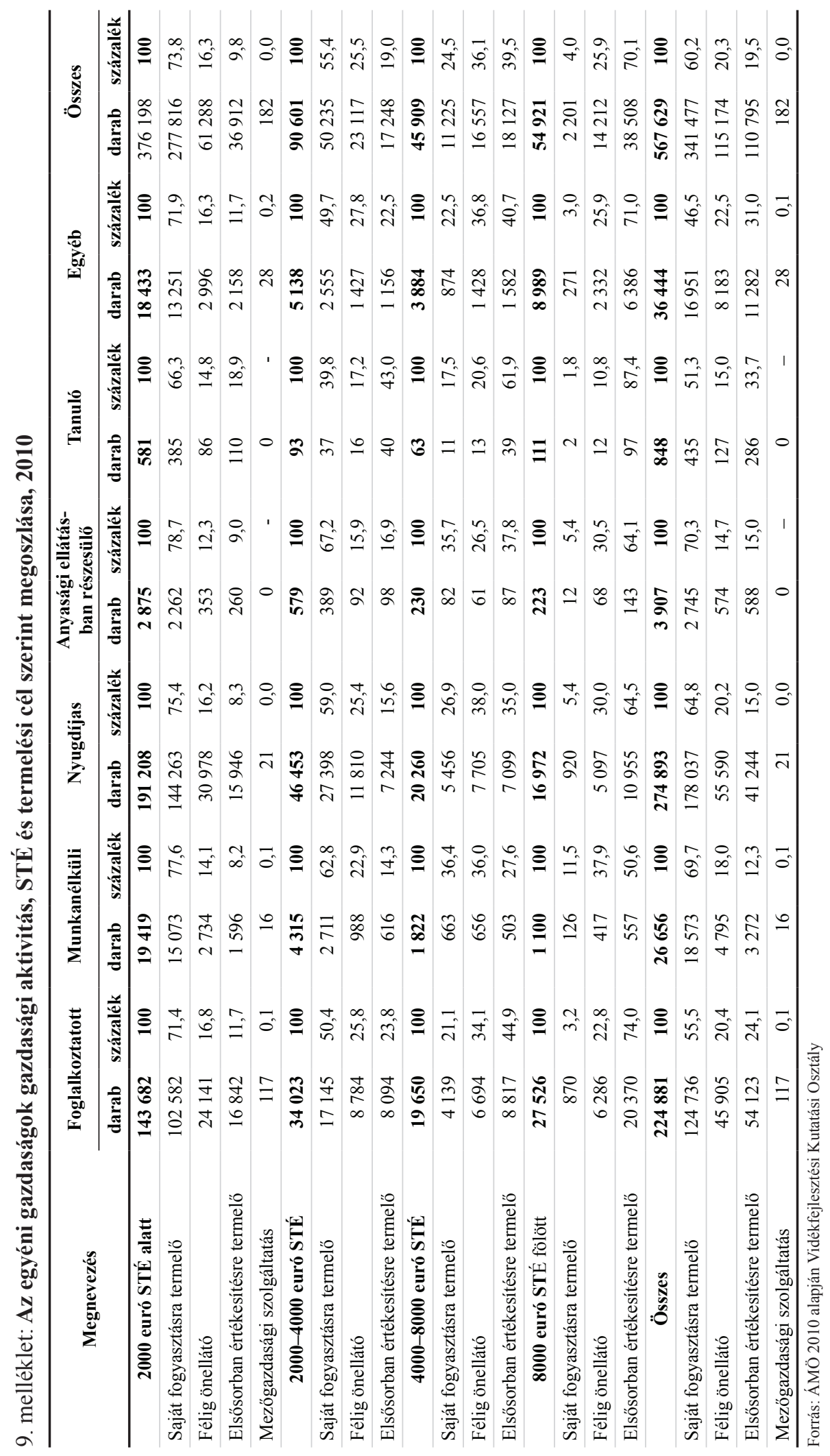




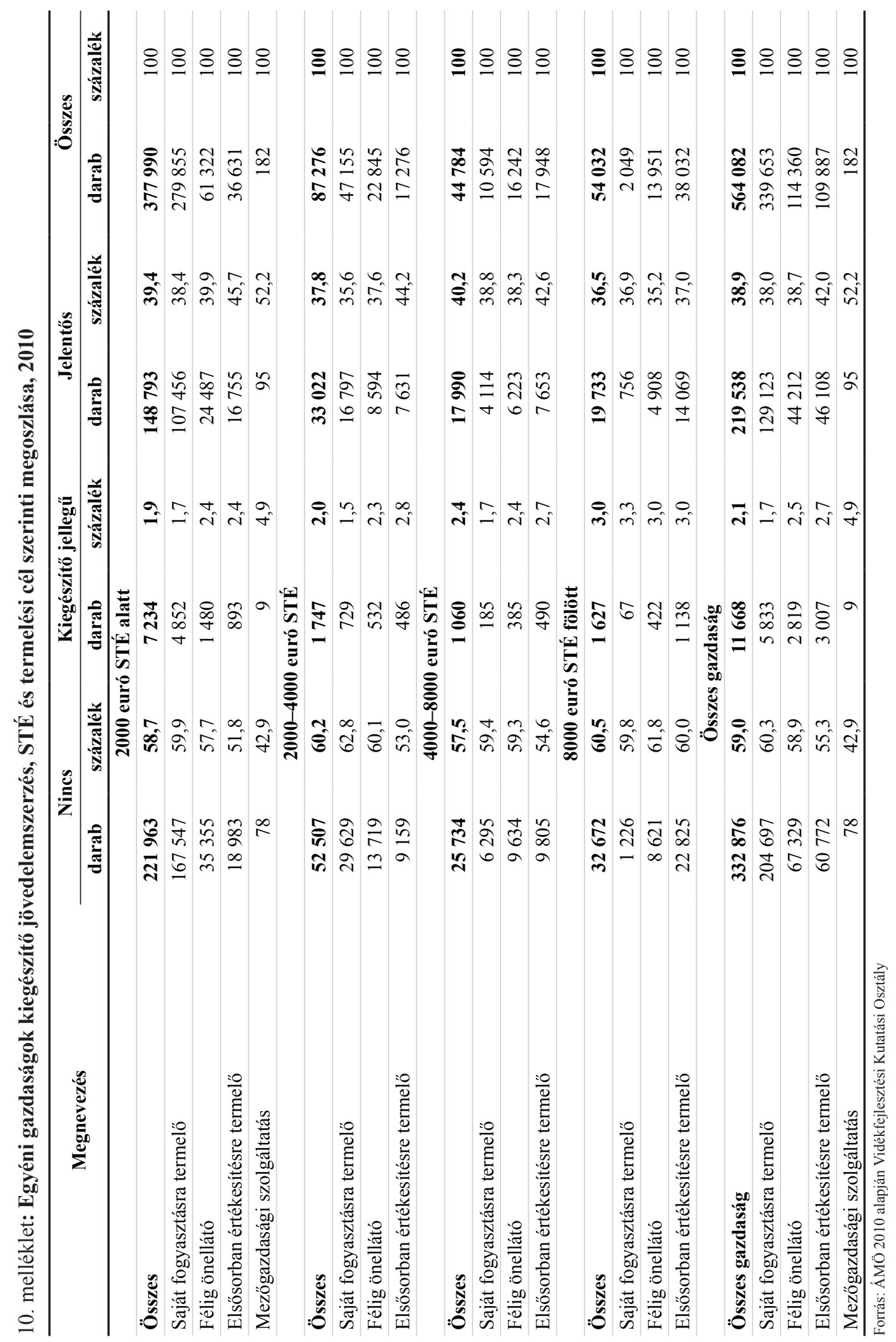


11. melléklet: Faktoranalízis eredményei

\section{Communalities}

\begin{tabular}{lcc}
\hline & Initial & Extraction \\
\hline Család létszáma (fö) & 1,000 &, 431 \\
\hline születési év & 1,000 &, 357 \\
\hline végzettség & 1,000 &, 497 \\
\hline
\end{tabular}

Extraction Method: Principal Component Analysis.

Total Variance Explained

\begin{tabular}{cccccc}
\hline \multirow{2}{*}{ Component } & \multicolumn{2}{c}{ Initial Eigenvalues } & \multicolumn{3}{c}{ Extraction Sums of Squared Loadings } \\
\cline { 2 - 6 } & Total & \% of Variance & Total & \% of Variance & Cumulative \% \\
\hline 1 & 1,285 & 42,837 & 1,285 & 42,837 & 42,837 \\
\hline 2 &, 898 & 29,939 & & & \\
\hline 3 &, 817 & 27,223 & & & \\
\hline
\end{tabular}

Extraction Method: Principal Component Analysis.

Forrás: AKI, 2016 


\section{2. melléklet: Klaszteranalízis eredményei}

\section{Final Cluster Centers}

\begin{tabular}{|c|c|c|c|}
\hline & \multicolumn{3}{|c|}{ Cluster } \\
\hline & 1 & 2 & 3 \\
\hline $\begin{array}{l}\text { Zscore: Adózás előtti eredmény (ezer HUF/hektár) - } \\
\text { m4659_03/m1117_08 }\end{array}$ &, 01546 &,- 01860 &,- 04230 \\
\hline humántőke pc & ,72881 & , 16472 &,- 66866 \\
\hline Zscore: Jövedelmtípusok száma &,- 23168 & 2,30771 &,- 44917 \\
\hline \multicolumn{4}{|l|}{ Number of Cases in each Cluster } \\
\hline \multirow{3}{*}{ Cluster } & & 1 & 98,000 \\
\hline & & 2 & 30,000 \\
\hline & & 3 & 111,000 \\
\hline Valid & & & 239,000 \\
\hline Missing & & & 62,000 \\
\hline
\end{tabular}

Cluster Number of Case

\begin{tabular}{lccccc}
\hline & & Frequency & Percent & $\begin{array}{c}\text { Valid } \\
\text { Percent }\end{array}$ & $\begin{array}{c}\text { Cumulative } \\
\text { Percent }\end{array}$ \\
\hline \multirow{3}{*}{ Valid } & 1 & 98 & 32,6 & 41,0 & 41,0 \\
& 2 & 30 & 10,0 & 12,6 & 53,6 \\
\cline { 2 - 6 } & 3 & 111 & 36,9 & 46,4 & 100,0 \\
\hline Missing & Total & 239 & 79,4 & 100,0 & \\
Total & Total & 62 & 20,6 & & \\
\hline
\end{tabular}

Forrás: AKI, 2016 


\section{Hivatkozások jegyzéke}

1. 1305/2013/EU rendelet az Európai Mezőgazdasági Vidékfejlesztési Alapból (EMVA) nyújtandó vidékfejlesztési támogatásról és az 1698/2005/EK tanácsi rendelet hatályon kívül helyezéséröl.

2. 1166/2008/EU rendelet a gazdaságszerkezeti felmérésekről és a mezőgazdasági termelési módszereket vizsgáló felmérésről, valamint az 571/88/EGK tanácsi rendelet hatályon kívül helyezéséröl.

3. 1995. évi CXVII. törvény a személyi jövedelemadóról.

4. 1991. évi IV. törvény a foglalkoztatás elősegítéséről és a munkanélküliek ellátásáról.

5. 106/2015. (IV. 23.) Kormányrendelet a kedvezményezett járások besorolásáról szóló 290/2014 (XI. 26.) Kormányrendelet módosításáról.

6. 52/2010. (IV. 30.) FVM rendelet a kistermelői élelmiszer-termelés, -előállítás és -értékesítés feltételeiröl.

7. Aragie, E. A. and McDonald, S. (2014): Semi-subsistence Farm Households and Their Implications for Policy Response. 17th Annual Conference on Global Economic Analysis, June 18-20, 2014, Dakar, Senegal.

8. Baptista, R. D. (2012): Technological Transition and the New Skills Required by the Agribusiness Sector. International Food and Agribusiness Management Review, Special Issue A, 5, 105-109.

9. Baranyai, Zs. (2010): Az együttmüködés elméleti és gyakorlati kérdései a magyar mezőgazdasági géphasználatban. Doktori értekezés (Szent István Egyetem, Gazdálkodás és Szervezéstudományok Doktori Iskola).

10. Baranyai, Zs., Kovács, Z. és Vásáry, M. (2013): Közös lónak valóban túrós a háta?! -avagy a magyar géphasználati együttmüködések vizsgálatának néhány tapasztalata. Gazdálkodás, 57 (2), 136-146.

11. Barnett, A., Blas, E. és Whiteside, A. (szerk.) (1996): AIDS Brief. Subsistence Agriculture. GPA/UNAIDS, 1996/4-5.

12. Belyó, P. (2011): A vállalkozói szféra fontosabb változásai a rendszerváltást követően. XXI. Század - Tudományos Közlemények, 2011/25. 39-70.

13. Biró, Sz., Dudás, Gy., Fieldsend, A., Fogarasi, J., Hamza, E., Miskó, K., Kürthy, Gy., Potori, N., Rácz, K., Tikász, I., Tóth, O., Vágó, Sz., Varga, E. and Varga, E. (2016): 'Research for AGRI Committee - Farm structural change in Central and Eastern Europe and the CAP' (79-196.) In Research for AGRI Committee - Structural change in EU farming: How can the CAP support a 21 st century European model of agriculture? Brussels: Policy Department B: Structural and Cohesion Policies, European Parliament. (ISBN 978-92-823-8818-1)

14. Biró, Sz. (szerk.), Hamza, E., Molnár, A., Rácz, K., Székely, E. (szerk.), Tóth, K., Tóth, O. és Varga, E. (2012): A mezőgazdasági foglalkoztatás bővítésének lehetőségei vidéki térségeinkben. Agrárgazdasági Kutató Intézet, Budapest.

15. Biró, Sz. (szerk.), Rácz, K. (szerk.), Csörnyei, Z., Hamza, E., Varga, E., Bene, E. és Miskó, K. (2015): Agrár- és vidékfejlesztési együttmüködések Magyarországon. Agrárgazdasági Kutató Intézet, Budapest. https://doi.org/10.7896/ak.1501 
16. Błażejczyk-Majka, L., Kala, R. and Maciejewski, K. (2012): Productivity and efficiency of large and small field crop farms and mixed farms of the old and new EU regions. Agric. Econ. - Czech, 58., https://doi.org/10.5513/jcea01/14.2.1251

17. Brüntrup, M. and Heidhues, F. (2002): Subsistence Agriculture in Development: Its Role in the Processes of Structural Change. Discussion Paper. Discussion Paper No. 1/2002, Institute of Agricultural Economics and Social Sciences in the Tropics and Subtropics, University of Hohenheim.

18. Burgerné Gimes, A. (2015): A kis (családi) gazdaságok helyzete az Európai Unióban. Gazdálkodás, 59 (1), 3-19.

19. Czagány, L. és Fenyővári, Zs. (2008): Inaktivitás és mezőgazdasági munkavégzés a vidéki Magyarországon. In Lengyel, I. és Lukovics, M. (szerk.): Kérdőjelek a régiók gazdasági fejlödésében. JATEPress, Szeged, 167-173.

20. Czene, Zs., Horkay, N., Péti, M., Ricz, J. és Sain, M. (2010): Helyi gazdaságfejlesztés. Ötletadó megoldások, jó gyakorlatok. Területfejlesztési füzetek 2., VÁTI, Budapest.

21. Davidova, S., Fredriksson, L. and Bailey, A. (2009): Subsistence and semi-subsistence farming in selected EU new member states. Working Paper. School of Economics discussion papers, No. 09, 20., https://doi.org/10.1111/j.1574-0862.2009.00411.x

22. Davidova, S., Matthew Gorton, M. and Fredriksson, L. (2010): Semi-subsistence farming in Europe: Concepts and key issues. Background paper prepared for the seminar "Semi-subsistence farming in the EU: Current situation and future prospects".

23. Davidova, S. and Thomson, K. (2014): Family farming in Europe challenges and prospects. In-depth analysis. Policy Department B: Cohesion and Structural Policies, European Parliament.

24. Dudek, M., Chmieliński, P., Karwat-Woźniak, B. and Wrzochalska, A. (2014): Human capital in the structural transformation process of rural areas and agriculture. Institute of Agricultural and Food Economics - National Research Institute (IAFE-NRI), Warsaw.

25. EC Agricultural and Rural Development (2011): What is a small farm? Brief N 2 - July 2011, http://ec.europa.eu/agriculture/rural-area-economics/briefs/pdf/02_en.pdf.

26. European Union (2013): Rural Development in the EU. Statistical and Economic Information Report 2013.

27. Eurostat, http://epp.eurostat.ec.europa.eu/portal/page/portal/statistics/search_database.

28. Féret, S. (2013): Semi-subsistence farming and small farms in the EU. Latest from Brussels, Main Stories, June 7, EU.

29. Fertő, I. (1999): A magyar mezőgazdaság strukturális problémái az Európai Unióhoz való csatlakozás tükrében. Magyar Tudományos Akadémia Közgazdaságtudományi Kutatóközpont, KTK/IE Mühelytanulmányok 1999/2.

30. Fertő, I. (2002): A mezőgazdasági termelés szerkezetének változásai a fejlett országokban, II. Az üzemnagyság és a mérethozadék problémája a mezőgazdaságban. Közgazdasági Szemle, XLIX. 2002. szeptember, 760-773.

31. Forgács, Cs. (2016): Is Specialization a Way for Small Farms in Central and Eastern European Countries to Adjust? Economic Science for Rural Development (42), 221-227. (ISBN 9789984-48-224-8) 
32. Galasi, P. és Nagy, Gy. (2012): Aktív munkaerő-piaci eszközök. In Fazekas, K. és Scharle, Á. (et al.): Nyugdíj, segély, közmunka. A foglalkoztatáspolitika két évtizede 1990-2010. OFA, Budapest.

33. Hamar, A. (2014): A kistermelés és a térbeli-társadalmi polarizáció. A Falu, 2014. tavasz.

34. Harangi-Rákos, M., Szabó, G. és Popp, J. (2013): Az egyéni és társas gazdaságok gazdasági szerepének föbb jellemzői a magyar mezőgazdaságban. Gazdálkodás, 57 (6), 532-543.

35. Heidhues, F. and Brüntrup, M. (2003): Subsistence agriculture in development: Its role in processes of structural change. In Abele, S. and Frohberg, K. (eds): Subsistence Agriculture in Central and Eastern Europe: How to break a vicious cycle? Halle/Saale: Institut fur Agrarentwicklung in Mittel- und Osteuropa.

36. Hubbard, C. (2009): Small Farms in the EU: How Small is Small? 111th EAAE-IAAE Seminar „Small Farms: Decline or Persistence”. University of Kent, Canterbury, UK.

37. Janák, K. (szerk.) (2011): Létminimum, 2010. Központi Statisztikai Hivatal, Budapest.

38. Juhász, A., Kürti, A., Seres, A. és Stauder, M. (2008): A kereskedelem koncentrációjának hatása a kisárutermelésre és a zöldség-gyümölcs kisárutermelők alkalmazkodása. Helyzetelemzés. MTA Közgazdaságtudományi Intézet, Mühelytanulmányok. MT-DP - 2008/2.

39. Juhász, A. (szerk.), Mácsai, É., Kujáni, K., Hamza, E. és Györe, D. (2012): A közvetlen termékértékesítés szerepe és lehetőségei a hazai élelmiszerek piacra jutásában. Élet a modern kiskereskedelmi csatornákon kívül? Agrárgazdasági Kutató Intézet, Budapest.

40. Juhász, P. (1998): Leckéink a mezőgazdaság új rendje érdekében. Szociológiai Szemle, 2.

41. Kabai, G. (2011): A munkahelyteremtés új útja a Dél-Dunántúlon a Sorsfordító-Sorsformáló munkaerő-piaci program. In Németh, N. (szerk.): A helyi kezdeményezésủ gazdaságfejlesztési programok vizsgálata. Esettanulmányok. MTA Közgazdaságtudományi Intézet, Budapest.

42. Kabai, G. és Németh, N. (2011): Egy „sorsfordító” falu: Gyulaj. In Németh, N. (szerk.): A helyi kezdeményezésű gazdaságfejlesztési programok vizsgálata. Esettanulmányok. MTA Közgazdaságtudományi Intézet, Budapest.

43. Kapronczai, I. (2011): A magyar agrárgazdaság napjainkban. Gazdálkodás, 55 (7), 615-628.

44. Kapronczai, I., Keszthelyi, Sz. és Takács, I. (2014): Gazdaságok jövedelmezőségének és hatékonyságának változása. Gazdálkodás, 58 (3), 222-238.

45. Keszthelyi, Sz. és Molnár, A. (2014): A Tesztüzemi Információs Rendszer eredményei 2012. AKI, Budapest.

46. Koós, B. (2014): Gyöngyös térsége a Marsden-i vidéktipológia szerint. http://real.mtak.hu/19387/1/koos_gyongyos_2014.pdf.pdf (Letöltés: 2016. április.)

47. Kovách, I. (2014): Subsistence and semi-subsistence farming in Hungary. From modernisation to ecological and social sustainability.

http://ifsa.boku.ac.at/cms/fileadmin/Proceeding2014/WS_2_11_Kovach.pdf (Letöltés: 2015. december.)

48. Kovách, I. (2016): Földek és emberek. Földhasználók és földhasználati módok Magyarországon. MTA Társadalomtudományi Kutatóközpont, Debreceni Egyetemi Kiadó, Budapest.

49. Kovács, K., Bihari, Zs. és Váradi, M. M. (1998): Agrárgazdasági szereplők az átmenet éveiben. Szociológiai Szemle, 1998. (3), 191-211. 
50. Kovács, K. és Váradi, M. M. (2002): Kutyaszorítóban: tanyás kisgazdaságok, kertész vállalkozások és az uniós csatlakozás. In Utak és útvesztők a kisüzemi agrárgazdaságban 1990-1999. MTA Néprajzi Kutatóintézet - MTA Társadalomkutató Központ, Budapest, 19-35.

51. Központi Statisztikai Hivatal (2008): A mezőgazdaság fejlettségének regionális különbségei - Változások a rendszerváltástól napjainkig. Szeged, 2008. december.

52. Központi Statisztikai Hivatal (2011a): Magyarország mezőgazdasága, 2010. Termelési típus, gazdálkodási cél, gazdaságméret (Általános mezőgazdasági összeírás - előzetes adatok 2).

53. Központi Statisztikai Hivatal (2011b): A 15-74 éves népesség napi időfelhasználása, 2010 (A 2009/2010. évi időmérleg-vizsgálat összefoglaló adatai). Statisztikai Tükör, V. évf. 87. sz.

54. Központi Statisztikai Hivatal (2012): A mezőgazdaság területi jellemzői, 2010. Budapest.

55. Központi Statisztikai Hivatal (2013): Útmutató az összeírás végrehajtásához. Budapest.

56. Loughrey, J., Donnellan, T., Hennessy, T. and Hanrahan, K. (2013): The Role of Pluriactivity in Farm Exit and Labour Supply Decisions. Factor Markets, Working paper, No. 67, August.

57. Márkusz, P. és Tóth, E. (2010): A szociális földprogramok szerepe a hátrányos helyzetű vidéki népesség megélhetésében. Kertgazdaság, 2010/1.

58. Mathijs, E. and Noev, N. (2004): Subsistence Farming in Central and Eastern Europe: Empirical Evidence from Albania, Bulgaria, Hungary and Romania. Eastern European Economics, 42 (6), 72-89.

59. Miniszterelnökség (2015): Magyarország - Vidékfejlesztési Program 2014-2020. 2015. július 22.

60. Molnár, Gy., Fazekas, B., Mózes, Zs., Óvári, A., Sárkány, Cs. és Schütt, M. (2012): Kiútprogram. Egy foglalkoztatási és szociális mikrohitelezési pilot program tanulságai.

http://www.kiutprogram.hu/index.php/hu/dokumentumtar/category/15-szakmai-ismertetokkutatasok.

61. Möllers, J., Zier, P., Frohberg, K., Buchenrieder, G. és Bojnec, S. (2009): Croatia's EU accession: socio-economic assessment of farm households and policy recommendations. Studies on the Agricultural and Food Sector in Central and Eastern Europe No. 48, Leibniz Institute for Agricultural Development in Central and Eastern Europe (IAMO), Halle (Saale), Germany.

62. Murphy, S. (2012): Changing Perspectives: Small-scale farmers, markets and globalisation. IIED/HIVOS, London.

63. Nagy, Zs. (2011): A magyar mezőgazdaság komplex (gazdasági, társadalmi, környezeti) vizsgálata az EU-csatlakozás tükrében. PhD-értekezés (Debreceni Egyetem).

64. Nemzeti Agrárgazdasági Kamara - Miniszterelnökség (2015): Vidékfejlesztési Program. Kézikönyv. Nemzeti Agrárgazdasági Kamara. Budapest

65. Nemzeti Foglalkoztatási Szolgálat (2015): Az aktív foglalkoztatáspolitikai eszközök fontosabb létszámadatai 2015-ben. Nemzetgazdasági Minisztérium.

66. Rácz, K. (2013): Szegénységkezelés aktív eszközökkel? Egy produktív szociálpolitikai program két évtizedes müködésének tapasztalatai. In Kovács, K. és Váradi, M. (szerk.): Hátrányban vidéken. Argumentum Kiadó, Budapest, 135-155.

67. Respect Tanácsadó és Szolgáltató Kft. (2009): Nemzeti Vidékfejlesztési Terv 2004-2006 expost értékelése, zárójelentés. Budapest, 2009. március 24. 
68. Seres, A., Felföldi, J., Kozak, A. és Szabó, M. (2011): Termelői szervezetek zöldség-gyümölcs kisárutermelőket integráló szerepe a nagy kereskedelmi láncoknak történő értékesítésben. MTA Közgazdaságtudományi Intézet, Mühelytanulmányok. MT-DP - 2011/22.

69. Somai, M. (2000): Cégvezetés (2000. október 1.): Agrárgazdálkodási struktúra az EU-ban.

70. Spéder, Zs. (1994): A mezőgazdasági kistermelés. In Tóth, I. Gy. és Sik, E. (szerk.): Társadalmi átalakulás 1992-1994. 75-82.

71. Spéder, Zs. (1997): Háztartások egy kistérségben. Szociológiai Szemle, 1, 5-37.

72. Swinnen, J. (ed.) és Knops, L. (ed.) (2013): Land, Labour and Capital Markets in European Agriculture. Centre for European Policy Studies (CEPS), Brussels.

73. Szabó, D. és Juhász, A. (2012): A piacok szerepe és lehetőségei a hazai élelmiszer-ellátási láncban. Gazdálkodás, 3, 217-229.

74. Székely, E. (2009): Nemzedékváltás a mezőgazdaságban. AKI, Budapest.

75. Szumelda, A. (2013): Is Small Beautiful? The Debate on the Future of Small Individual Farms in Poland. Eastern European Countryside, 19, 219-250., https://doi.org/10.2478/eec-2013-0010

76. Takács, I. és Kovács, G. (2002): Az egyéni gazdaságok tőkehatékonyságának alakulása a Közép-magyarországi térségben. http://miau.gau.hu/miau/60/fanclub/mfc01/qcis12.doc.

77. Thomson, K. J. and Davidova, S. (2014): Economic Aspects of Family Farming in the European Context. Discussion Paper prepared for presentation at the 88th Annual Conference of the Agricultural Economics Society, AgroParisTech, Paris, France.

78. Tóth, E. (szerk.) (2001): Az agrárfoglalkoztatás jellemzői, különös tekintettel a nők munkaerőpiaci helyzetére (1990-2000). AKI, Budapest.

79. Tóth, E. (szerk.) (2002): Az agrárgazdaság átalakuló szerepe a vidéki foglalkoztatásban, különös tekintettel az EU-csatlakozásra. AKI, Budapest.

80. Tóth, E. és Hamza, E. (2006): Az egyéni gazdaságok eltartóképessége, megélhetésben betöltött szerepe. AKI, Budapest.

81. Tóth, E., Ludvig, K. és Márkusz, P. (2009): A vidéki megélhetés jellemzői és tipikus modelljei a leghátrányosabb helyzetü kistérségekben. AKI, Budapest.

82. Tóth, O. (2014): A magyar és egyes uniós tagállamok mezőgazdaságának összehasonlító elemzése. Acta Carolus Robertus 4 (2), 119-134.

83. UK Farm Classification Document (2014):

http://farmbusinesssurvey.co.uk/DataBuilder/defra-stats-foodfarm-farmmanage-fbs-UK_

Farm_Classification.pdf

84. Valkó, G. (szerk.) (2011): Magyarország mezőgazdasága, 2010. Központi Statisztikai Hivatal.

85. Valkó, G. (2014): A gazdaságszerkezet változása 2000-2013 között. Gazdálkodás, 58 (3), 211-221.

86. Van der Ploeg, J. (2010): The peasantries of the twenty-first century: the commoditisation debate revisited. The Journal of Peasant Studies, 37 (1), 1-30.,

https://doi.org/10.1080/03066150903498721

87. Wharton, C. R. (1970): Subsistence Agriculture and Economic Development. Frank Cass, London, p. 209-227. 